REGIONALIZATION OF FLOOD DISCHARGES FOR RURAL, UNREGULATED STREAMS IN NEW YORK, EXCLUDING LONG ISLAND

By Richard Lumia

U.S. GEOLOGICAL SURVEY

Water-Resources Investigations Report 90-4197

Prepared in cooperation with the

NEW YORK STATE DEPARTMENT OF TRANSPORTATION

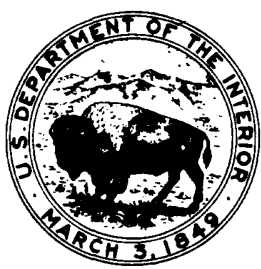

Albany, New York 


\section{DEPARTMENT OF THE INTERIOR \\ MANUEL LUJAN, JR., Secretary}

\section{U.S. GEOLOGICAL SURVEY}

Dallas L. Peck, Director

For additional information write to:

U.S. Geological Survey

P.O. Box 1669

Albany, NY 12201
Copies of this report may be purchased from:

U.S. Geological Survey

Books and Open-File Reports Section

Denver Federal Center

Box 25425

Denver, CO 80225 


\section{CONTENTS}

Abstract ... Page

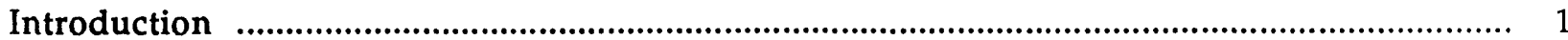

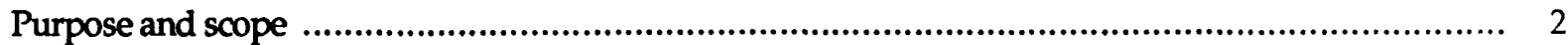

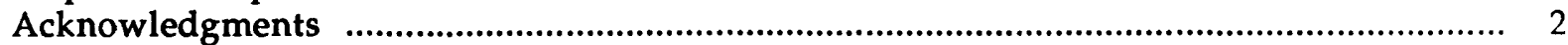

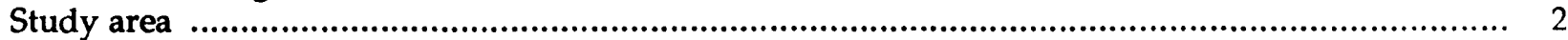

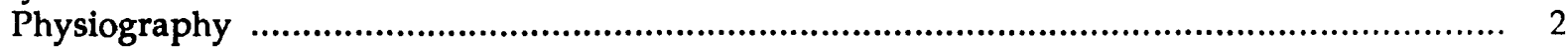

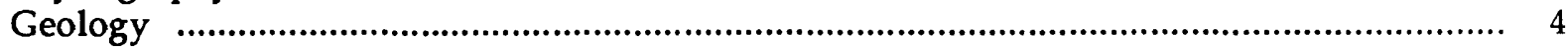

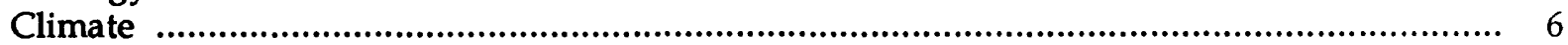

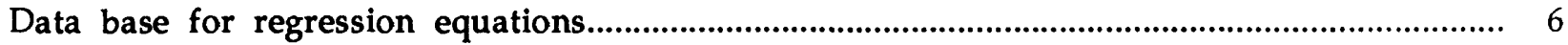

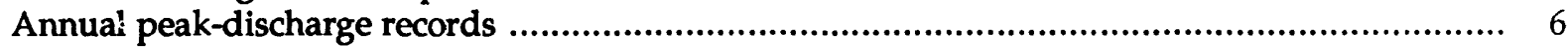

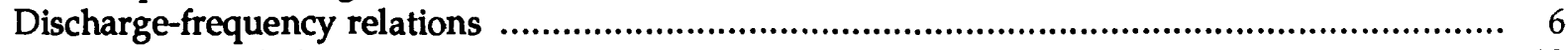

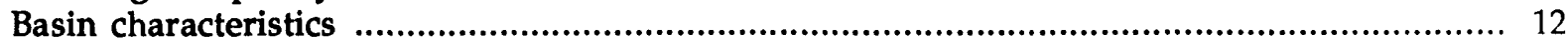

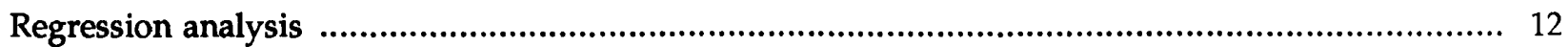

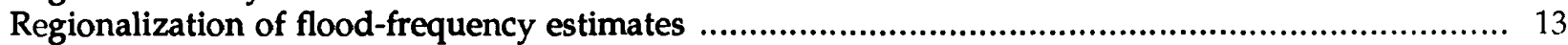

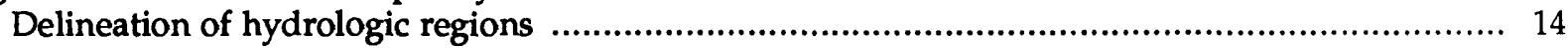

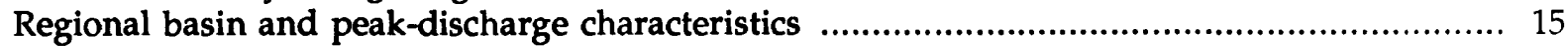

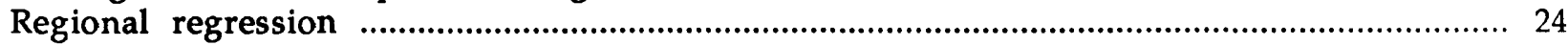

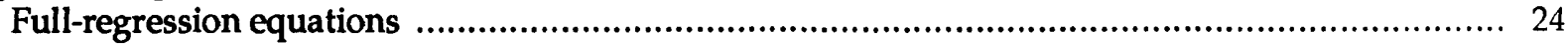

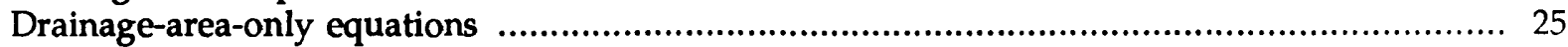

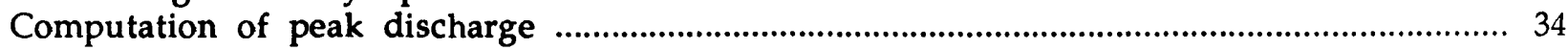

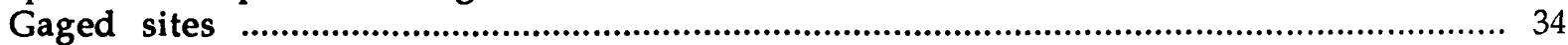

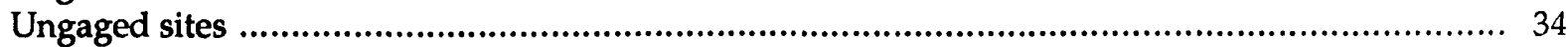

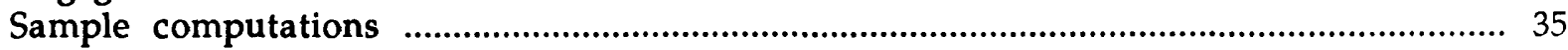

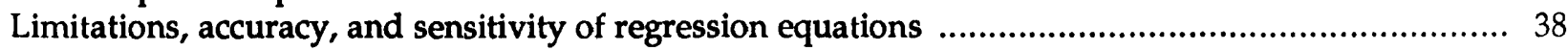

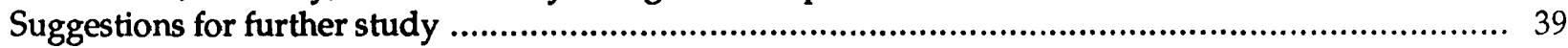

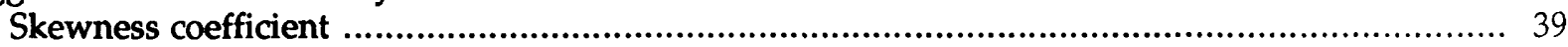

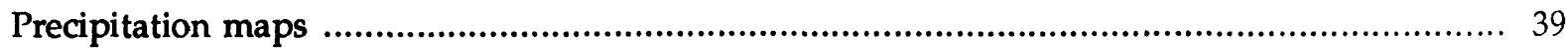

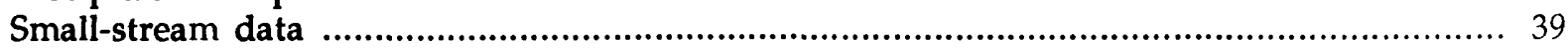

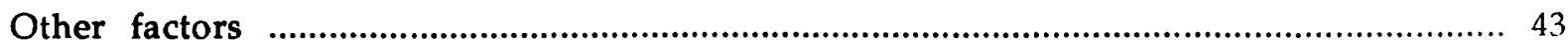

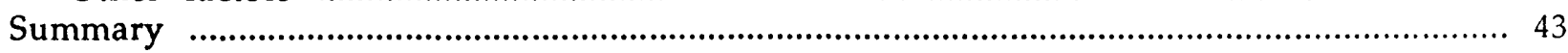

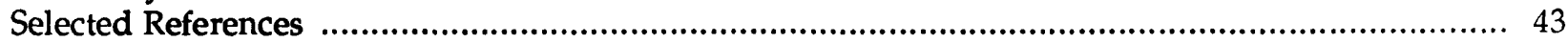

\section{TABLES}

Table 1. Results of Wilcoxon Signed Ranks test on the 50-year peak-discharge regression residuals for eight hydrologic regions in New York

2. Full-regression equations for estimating peak discharges in each of eight hydrologic

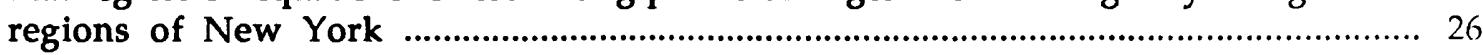

3. Summary of full-regression equations for estimating peak discharges in New York ........... 28

4. Correction factors to adjust regional full-regression equations for transformation bias ........ 28

5. Regional flood-frequency equations based on drainage area only ................................ 29

6. Range in regional basin characteristics used in the regression analyses for eight hydrologic regions in New York ........................................................................ 38

7. Results of sensitivity analysis showing percent change in computed 50-year peak discharges within each of eight hydrologic regions of New York .................................. 40

8. Gaging stations and selected peak-discharge records used in the study $\ldots \ldots \ldots \ldots \ldots \ldots \ldots \ldots . \ldots \ldots$

9. Selected flood characteristics for gaging stations used in the study ............................... 67

10. Selected basin characteristics for gaging stations used in the study ............................... 108 


\section{ILLUSTRATIONS}

Figures 1-3. Maps of New York showing:

1. Physiographic provinces

2. Distribution of major bedrock types ….............................................................. 4

3. Generalized distribution of soil associations ....................................................... 5

4. Example of a flood-frequency curve: Wappinger Creek near Wappingers Falls (station 01372500).

5. Maps of New York showing flood-boundary delineations for five selected storms, 1913-85

6-14: Graphs showing:

6. Annual peak discharges and 10- and 100-year recurrence intervals for selected gaging stations in each of eight hydrologic regions of New York

7. Comparison of 50-year peak-discharge residuals from the statewide regression for gaging stations within eight hydrologic regions of New York, before and after regionalization

8. Comparison of selected basin characteristics for gaging stations within eight hydrologic regions of New York

9. Comparison of selected peak-discharge characteristics for gaging stations within eight hydrologic regions of New York

10. Stations within each of the eight hydrologic regions in New York and for all stations combined distributed by:

A. Length of period of record

B. Drainage-area size

11. Comparison of the monthly frequency of peak flows within each of the eight hydrologic regions in New York and for all stations combined

12. Monthly frequency of annual peak flows at gaging stations used in the study for selected drainage-area sizes

13. Observed 50-year discharges for stations within eight hydrologic regions of New York and 50-year discharges predicted from:

A. Equations of Zembrzuski and Dunn (1979)

B. Generalized least squares full-regression equations

C. Full and drainage-area-only regression equations 33

14. Comparison of station skews with generalized map skews from U.S. Water Resources Council (1981), for gaging stations within eight hydrologic regions of New York

\section{PLATES (in pocket)}

Plate 1.--Map showing distribution of mean annual precipitation in New York (excluding Long Island), 1931-60.

2.--Map showing locations of hydrologic regions and streamflow-gaging stations used in the study. 


\section{CONVERSION FACTORS AND VERTICAL DATUM}

Multiply

inch (in)

foot $(f t)$

mile (mi)

square mile $\left(\mathrm{mi}^{2}\right)$

cubic foot $\left(\mathrm{ft}^{3}\right)$

cubic foot per second $\left(\mathrm{ft}^{3} / \mathrm{s}\right)$
By

Length

25.40

0.3048

1.609

Area

2.590

Volume

0.02832

Flow

0.02832
To obtain

millimeter

meter

kilometer

square kilometer

cubic meter

cubic meter per second

Sea Level: In this report, "sea level" refers to the National Geodetic Vertical Datum of 1929-a geodetic datum derived from a general adjustment of the first-order level nets of the United States and Canada, formerly called Sea Level Datum of 1929. 


\title{
REGIONALIZATION OF FLOOD DISCHARGES FOR RURAL, UNREGULATED STREAMS IN NEW YORK, EXCLUDING LONG ISLAND
}

\author{
By Richard Lumia
}

\begin{abstract}
Techniques are presented for estimating the magnitude and frequency of flood discharges on rural, unregulated streams in New York, excluding Long Island. Peak discharge-frequency data and basin characteristics from 313 streamflow-gaging stations in New York and adjacent States were used to develop multiple linear regression equations for floods with recurrence intervals of 2 to 500 years. A generalized least-squares (GLS) procedure was used to develop the regression equations. A separate set of equations was developed for each of eight hydrologic regions of New York; standard errors of prediction range from 17 to 51 percent. Significant explanatory variables included in the regression equations are drainage area, main-channel slope, percent basin storage, mean annual precipitation, percent forested area, average main-channel elevation, and a basin-shape index. Drainage areas for sites used in the analyses ranged from 0.41 to 4,773 square miles.

Methods of computing peak discharges differ, depending on whether the estimate is for a gaged or ungaged basin, and whether the basin crosses hydrologic-region boundaries. Examples of computations are included. Results of the GLS equations were statistically and graphically compared with those obtained from previously (1979) published equations and were found to be unbiased and generally more accurate.

Basin characteristics, log-Pearson Type III statistics, and regression and weighted estimates of the discharge-frequency relations are tabulated for the gaging stations used in the regression analyses. Sensitivity analyses showed that mean-annual precipitation and drainage area are the variables to which computed discharges are most sensitive in the regression equations.
\end{abstract}

\section{INTRODUCTION}

Flood damage is a constant threat along flood plains and thus is a concern for local and regional managers and planners. The effective management of flood-prone areas and the design of structures along rivers and streams requires knowledge of the magnitude and frequency of floods. Although several U.S. Geological Survey reports provide techniques for estimating the magnitude and frequency of floods on rural, unregulated streams in New York by the index-flood method (Robison, 1961; Speer and Gamble, 1965; Tice, 1968; Wiitala, 1965), and by ordinary least-squares multiple-regression techniques (Darmer, 1970, and Zembrzuski and Dunn, 1979), an additional 12 years of annual peakdischarge data, new guidelines for computing station flood-frequency curves as outlined in U.S. Water Resources Council Bulletin 17B (1981), and new statistical methods as applied to multiple-regression analysis warranted revision of techniques given previously.

Since the completion of the study by Zembrzuski and Dunn (1979), the U.S. Geological Survey, in cooperation with New York State Department of Transportation, has been developing improved methods for estimating the magnitude and frequency of floods at gaged or ungaged sites on rural, unregulated streams in New York, excluding Long Island. Peak-discharge characteristics can be estimated through multiple regression equations based on measured basin and climatic characteristics within the drainage area upstream from the site of interest. Procedures for estimating peak discharges with recurrence intervals of 2,5,10,25,50,100, and 500 years differ according to whether the estimate is for a gaged or ungaged basin, and whether the basin crosses hydrologic-region boundaries or State lines. In this study, regression equations were developed for eight hydrologic regions of New York from 
data collected through September 1987 at 313 gaged sites in and adjacent to New York. Estimated standard errors of prediction for the regression equations range from 17 to 51 percent.

Development of techniques for estimating peak discharges on regulated streams, urbanized basins, and streams on Long Island was beyond the scope of this study. Peak discharges for urban areas can be estimated through techniques of Sauer and others (1983), Stedfast (1986), and Lumia (1984) if the effects of urbanization can be quantified.

\section{Purpose and Scope}

This report presents techniques to estimate the magnitude and frequency of floods on rural, unregulated streams within eight hydrologic regions of New York at gaged sites, ungaged sites, and ungaged sites on gaged streams. It supersedes previous U.S. Geological Survey reports that provide techniques for estimation of flood magnitude and frequency on rural, unregulated streams in New York.

The report discusses the delineation of the eight hydrologic regions through statistical and hydrologic analyses and presents sets of equations for each of the eight hydrologic regions. It also describes use of the equations and includes sample computations as well as tables of selected flood and basin characteristics and summaries of statistical analyses.

\section{Acknowledgments}

The New York State Department of Environm`ntal Conservation, the U.S. Army Corps of Engineers, the Hudson River - Black River Regulating District, the New York Power Authority, Niagara Mohawk Power Corporation, New York City Department of Environmental Protection, Cornell University, and several other municipal and county governments provided support for data-collection programs.

\section{STUDY AREA}

Physiographic and geologic characteristics were considered in delineation of hydrologic-region boundaries. These factors influence the timing and magnitude of flood response, although many were not directly included in the regression equations.

\section{Physiography}

New York (excluding Long Island) encompasses parts or all of eight physiographic provinces (fig. 1), which range from high relief in the Adirondack and Catskill Mountains to low relief along the Great Lakes, the St. Lawrence River valley, and the Hudson and Mohawk River valleys. In northern New York, the Adirondack province covers about $10,000 \mathrm{mi}^{2}$. The western half of the province and parts of the southern and northern margins are plateaulike. Lakes and ponds are abundant (about 2,000 ), especially in and near the mountains. The eastern half of the Adirondack province is mountainous; some elevations exceed 5,000 ft above sea level (Fenneman, 1938). The St. Lawrence Valley of extreme northern New York is a smooth glacial plain with elevations dropping below $200 \mathrm{ft}$ along the St. Lawrence River. The Mohawk Valley, just south of the Adirondack province, drains parts of the southern Adirondacks to the Hudson River.

The two major physiographic divisions of western New York are the Central Lowlands and the Appalachian Plateau. The Central Lowlands in New York extend east from Lake Erie, north of the Finger Lakes region adjacent to Lake Ontario, to just west of the Mohawk and St. Lawrence Valleys and the Adirondacks. South of Lake Ontario, the lowland plain abuts against the northern escarpment of the Appalachian Plateau, while east of Lake Ontario the plain comes to an end against the Tug Hill plateau. Drainage throughout the Central Lowlands is generally toward Lakes Erie and Ontario. The Appalachian Plateau extends throughout the southern part of western New York east to and including the Catskill Mountains and southern sections of the Mohawk River basin. The Appalachian Plateau is characterized by hilly terrain; its highest elevations are in the Allegheny and Catskill Mountains. 
Physiographic divisions in eastern and southeastern New York include the Valley and Ridge province, the New England province, and the Piedmont province. The Valley and Ridge province extends from the New Jersey border, north through the lower Hudson River Valley to the southern end of Lake Champlain. Longitudinal drainage is prominent in the Hudson-Champlain section of the province. The New England province also extends from the New Jersey border northward, crossing the southern part of the Hudson River. It includes the Taconic Mountains, running along the southeastern border of New York north to just south of Lake Champlain. The Piedmont province includes a small lowland area in southeastern New York just north of New Jersey.

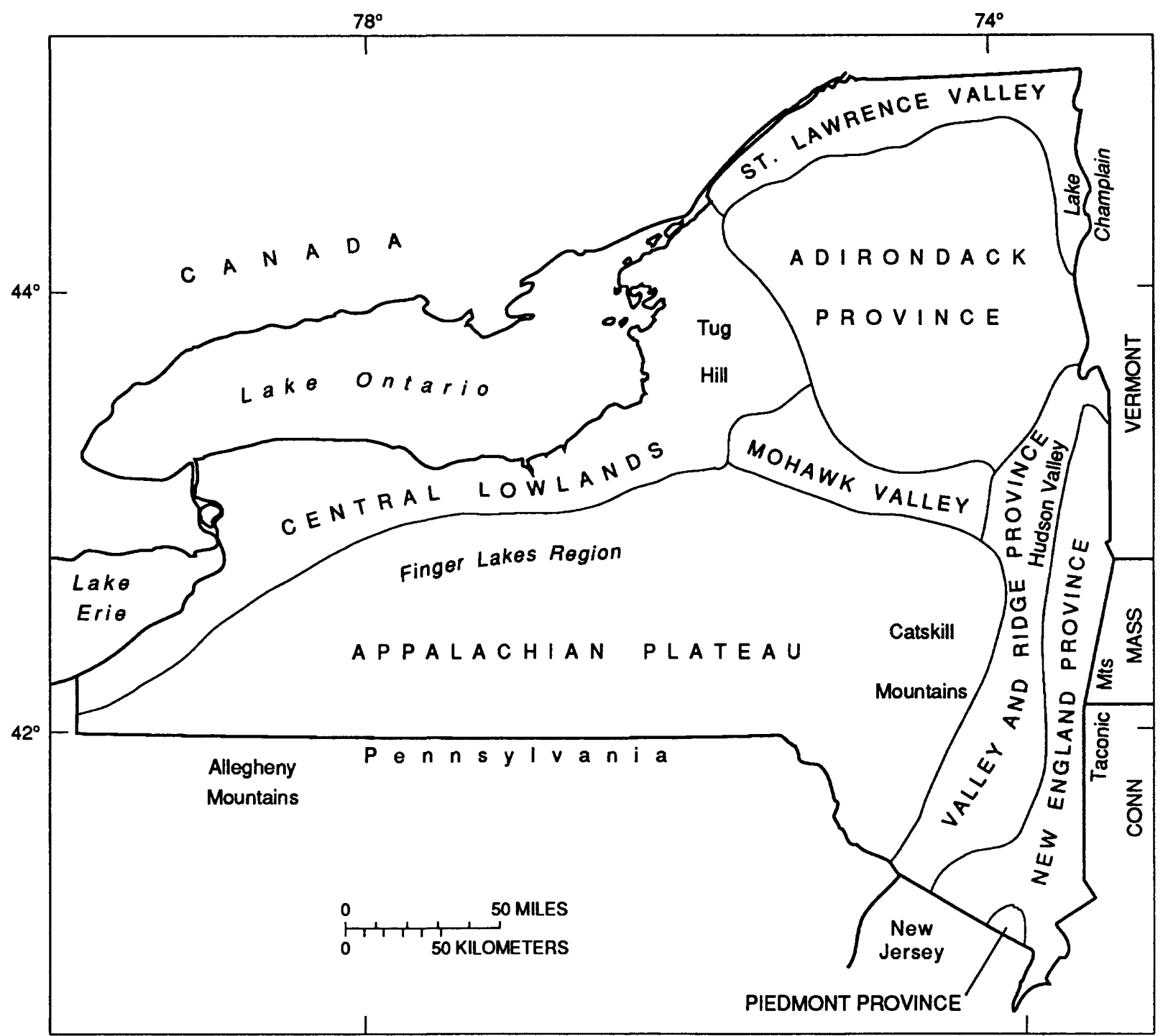

Base from U.S. Geological Survey

State Base Map

Shaded relief, 1:500,000, 1956

Figure 1.--Physiographic provinces of New York. (Modified from Lyford and others, 1984, fig. 2). 


\section{Geology}

Crystalline rocks dominate the Adirondack and New England provinces but contain carbonate rocks in outcrop fringes (escarpments) along the northern and eastern edges of the Appalachian Plateau province, in isolated areas of the St. Lawrence Valley, and in eastern New York. The general distribution of major bedrock units in New York is depicted in figure 2. Shale, the most extensive bedrock unit, predominates in the Appalachian Plateau, western Central Lowland, the Mohawk Valley, and the Valley and Ridge province. Sandstone dominates in the Piedmont, St. Lawrence Valley, and eastern Central Lowland provinces.

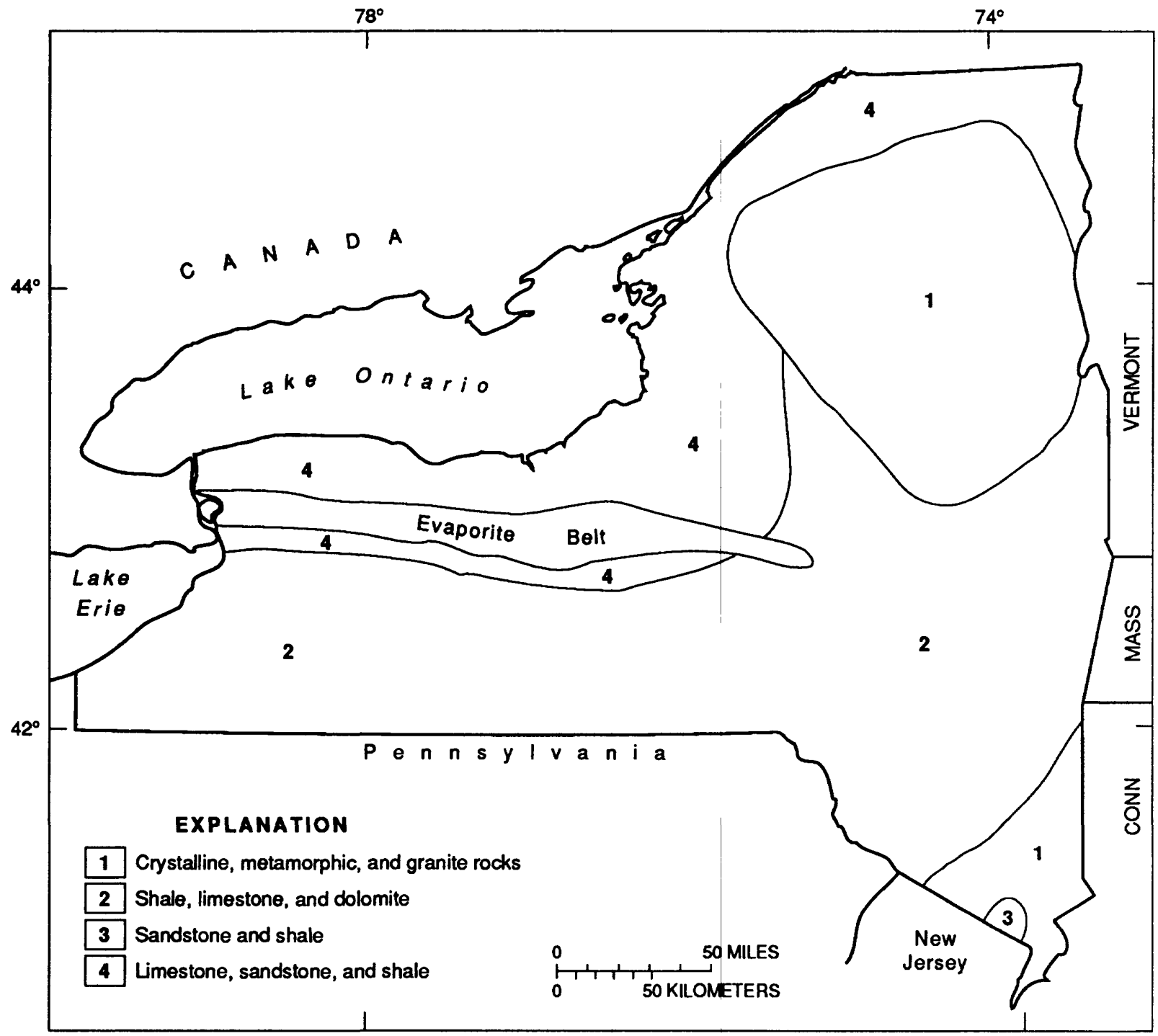

Base from U.S. Geological Survey

State Base Map

Shaded relief, 1:500,000, 1956

Figure 2.--Distribution of major bedrock types in New York. (Modified from Lyford and others, 1984, fig. 6) 
Bedrock in New York (excluding Long Island) is covered with glacial deposits of till and stratified drift of variable thickness. The generalized distribution of soil associations in New York is shown in figure 3. The till mantles the uplands and small tributary valleys and generally is found beneath stratified drift in the larger valleys. Stratified drift forms the floors of large valleys and flat plains or terraces where bedrock relief is low. The stratified drift includes clay, silt, sand, and meltwater deposits of sand and gravel. The sand and gravel deposits form the principal aquifer systems of New York.

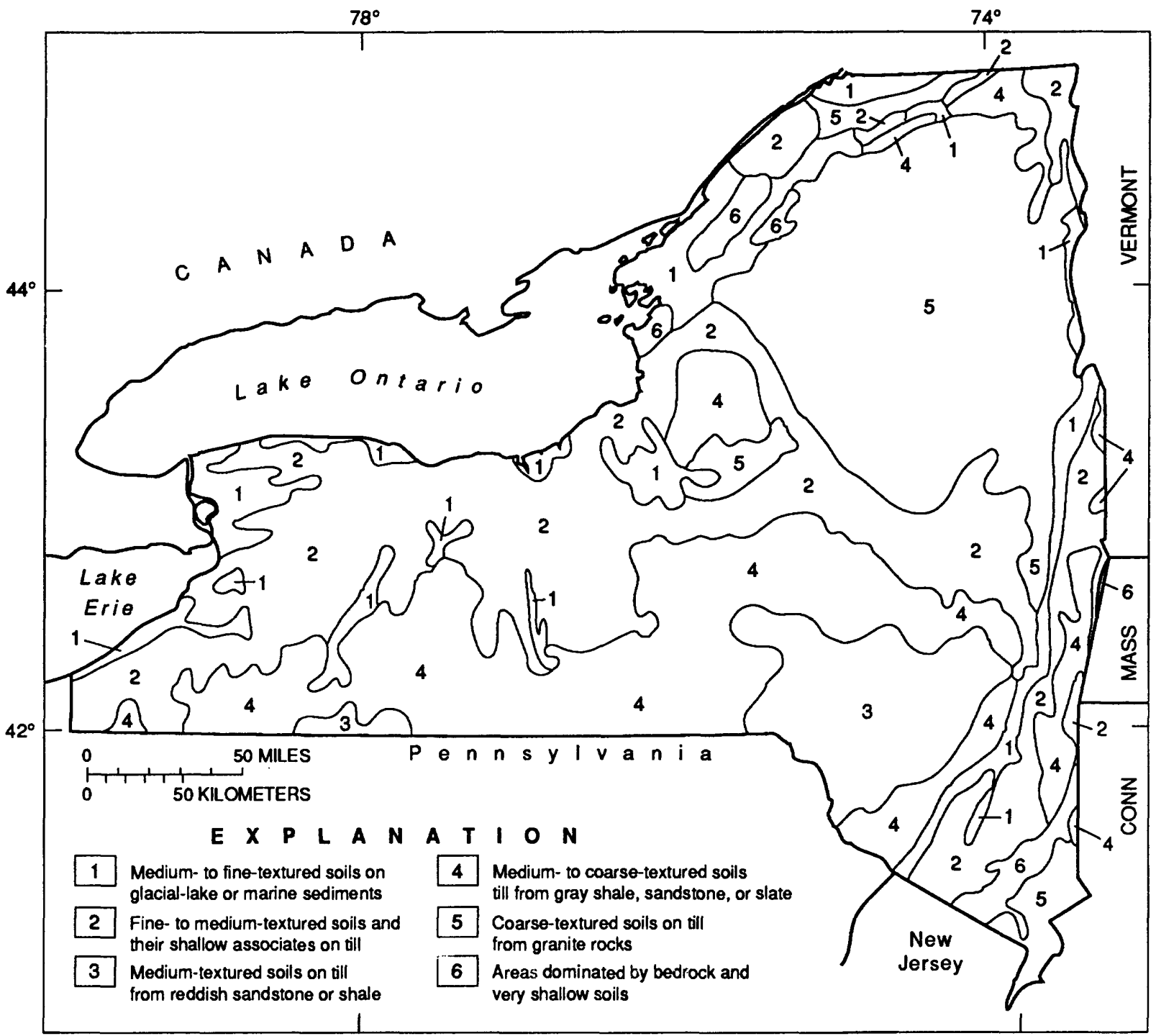

Base from U.S. Geological Survey

State Base Map

Shaded relief, 1:500,000, 1956

Figure 3.--Generalized distribution of soil associations in New York. (Modified from Cline, 1961, pl. 1.) 


\section{Climate}

The climate of New York is the humid continental type; cool, dry air masses move generally eastward through the State throughout the year, and warm, humid, maritime tropical air masses from the south move northeastward during the summer. Mean annual precipitation ranges from almost $30 \mathrm{in}$. along Lakes Ontario and Champlain to about 60 in. in the southern Catskill Mountains (pl. 1).

The areal distribution of precipitation reflects the topographic relief and the general eastward-tonortheastward storm movements. New York has a fairly uniform distribution of precipitation during the year and has no distinct rainy or dry season.

Regional differences in topography, elevation, and proximity to large bodies of water result in a great variation of snowfall throughout the State. Maximum seasonal snowfall, averaging more than 175 in., occurs on the western and southwestern slopes of the Adirondacks and Tug Hill (National Oceanic and Atmospheric Administration, 1980). A secondary maximum of more than 150 in. prevails some 10 to $30 \mathrm{mi}$ inland from Lake Erie. The minimum seasonal snowfalls ( 25 to $35 \mathrm{in}$ ) occur in extreme southeastern New York, and the minimum upstate snowfalls ( 40 to $50 \mathrm{in}$.) occur in the Chemung and mid-Genesee River Valleys and near the Hudson River in Orange, Rockland, and Westchester Counties up to southern Albany County. (Locations are shown on pl.1). On average, some of the winter snowpack is still unmelted by mid-March over all but the extreme southeastern part of the State. In mid-March, as much as 10 in. of water content can still remain in the snowpack of the Adirondack Mountains and in the highlands to the east of Lake Ontario.

The greatest potential for floods is in the early spring, when substantial rains combine with rapid melting of snow to produce heavy runoff. Almost half of the State's annual runoff occurs from midFebruary through mid-May. Local flooding, primarily within smaller drainage basins, is generally caused by summer thunderstorms. Occasionally hurricanes can cause severe flooding, particularly in southeastern parts of the State.

\section{DATA BASE FOR REGRESSION EQUATIONS}

The regression equations that provide estimates of the streamflow characteristics in this study were developed from peak-discharge and basin-characteristic data from gaging stations in New York and adjacent States.

\section{Annual Peak-Discharge Records}

The flood-frequency analyses for this study are based on annual peak-discharge data collected through September 1987 from 313 continuous-record and partial-record gaging stations (pl. 2). Of these sites, 284 are in New York, and 29 are in adjacent States. Periods of peak-discharge record for these stations range from 10 to 84 years.

Annual peaks from gaging stations having at least 10 consecutive years of unregulated, nonurbanized record were selected for the analysis. If more than 20 percent of the drainage area at a gaging station was upstream from a controlled reservoir, the stream was considered regulated, in accordance with analyses of Zembrzuski and Dunn (1979). Similarly, if more than 15 percent of a site's drainage area was affected by manmade changes (impervious area, channelization, diversions, and so forth), the stream was considered urbanized (Sauer and others, 1983).

The drainage areas of the 313 gaging stations selected for the analysis ranged from 0.41 to $4,773 \mathrm{mi}^{2}$. A list of gaging stations used in the study, as well as selected peak-discharge records, is given in table 8 (at end of report). Much of the information in table 8 was obtained from Robideau and others (1984).

\section{Discharge-Frequency Relations}

The discharge-frequency relation of a streamflow-measurement site is usually expressed in terms of exceedance probability, or recurrence interval. Exceedance probability is the probability that a flood of specified magnitude will be equaled or exceeded in any 1 year. Recurrence interval, the reciprocal of 
exceedance probability, is the average time interval between occurrences of a flood of equal or greater magnitude. For example, a 100-year flood has a 1-percent chance of occurring in any 1-year period.

The representation of a discharge-frequency relation on a graph is known as a flood-frequency curve; an example is depicted in figure 4. Discharge-frequency relations for each of the 313 gaging stations included in the study were developed by fitting the logarithms of the annual peak-discharges to a Pearson Type III distribution according to guidelines recommended by U.S. Water Resources Council (1981); the resulting data were analyzed by means of U.S. Geological Survey flood-frequency programs (Kirby, 1981). Adjustments to the frequency curves were made to account for historical information and high and low outliers. The coefficient of skewness was estimated as a weighted average of the systematic (station) skew and a generalized map skew (U.S Water Resources Council, 1981). Results of the discharge-frequency analyses for each gaging station are summarized in table 9 (at end of report).

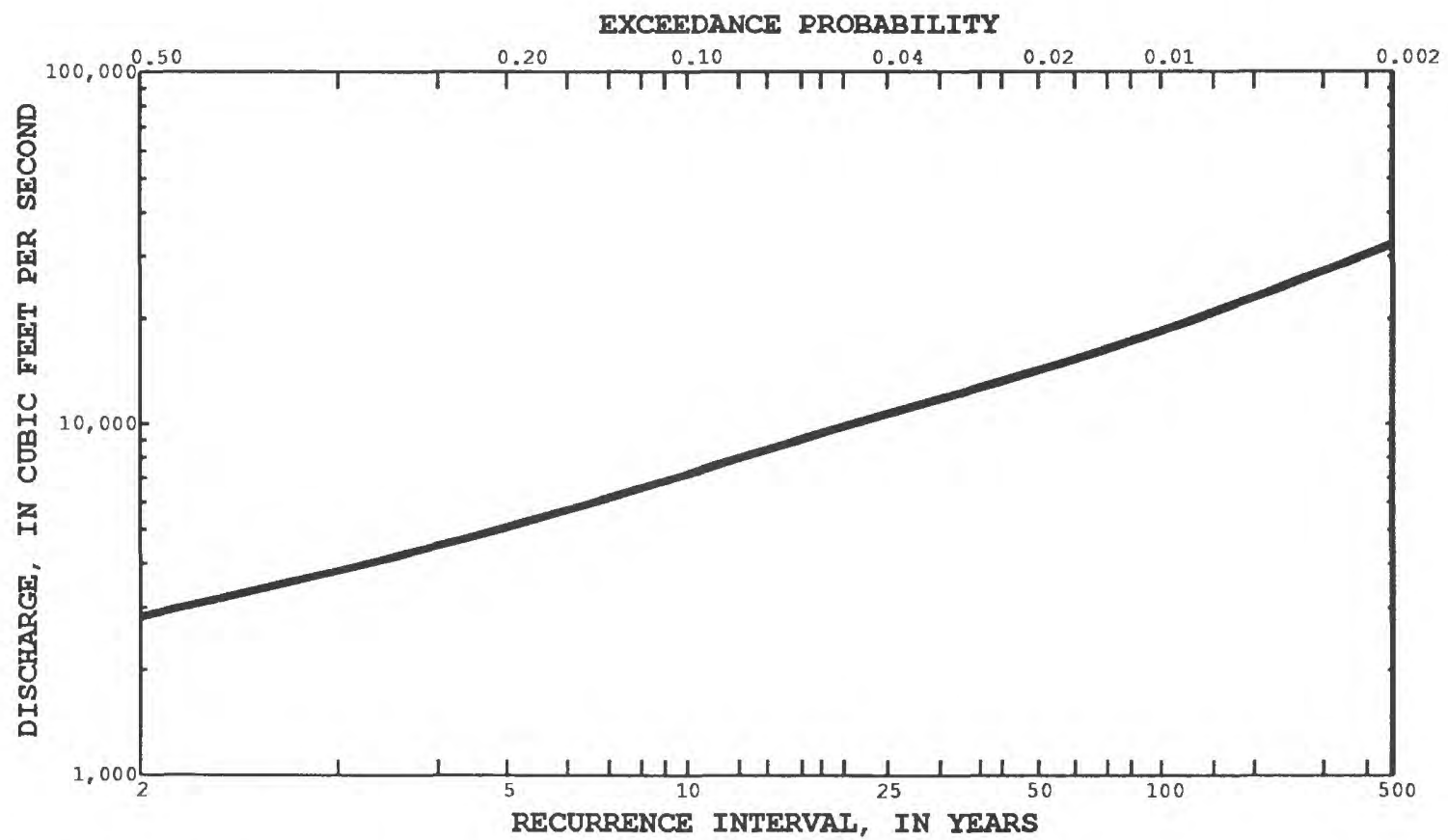

Figure 4.--Flood-frequency curve for Wappinger Creek near Wappingers Falls (station 01372500).

Caution should be exercised in using information from some of the stations listed in table 9 because several of the streams are now regulated. As noted in table 9, all data entries for these streams reflect preregulation periods and are not generally applicable to present conditions.

The boundaries for selected recurrence intervals for five of the most severe floods in New York since 1913 are shown on the maps in figure 5; most streams in the State were ungaged before 1913 (U.S. Geological Survey, in press). Flood severity was evaluated in terms of magnitude, extent, loss of life, and property damage. Of the five floods illustrated, three $(1913,1949$, and 1984) were caused by winter/spring storms, and two (1955 and 1972) by summer/fall storms (hurricanes). Figure 6 shows annual peak discharges at eight selected gaging stations in New York. Of note are the occurrences of 100-year floods in two consecutive years (1955-56) at Wallkill River at Gardiner, and no 100-year flood at Schoharie Creek at Prattsville during its 78 years of record. The regions indicated on figure 6 are discussed in the section "Regionalization of Flood-frequency Estimates." The maximum known discharges and associated recurrence intervals for all gaging stations used in the analysis are listed in table 8 (at end of report). 


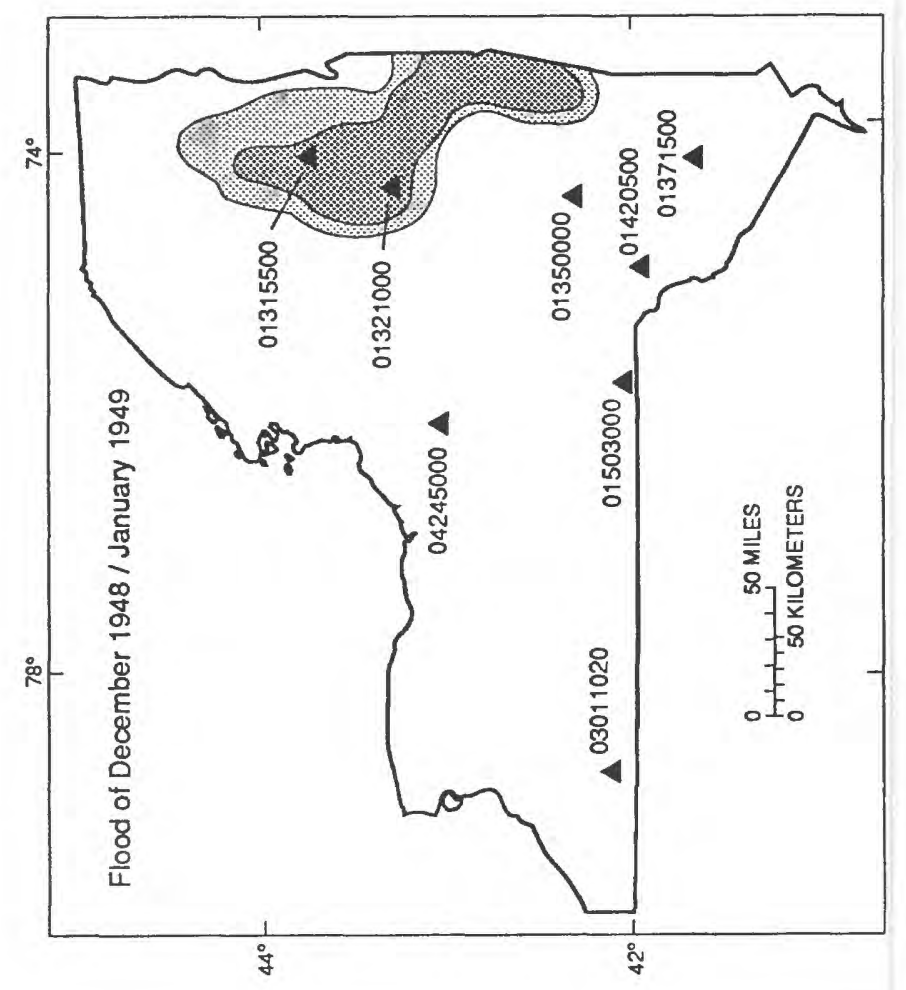

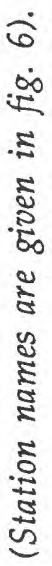

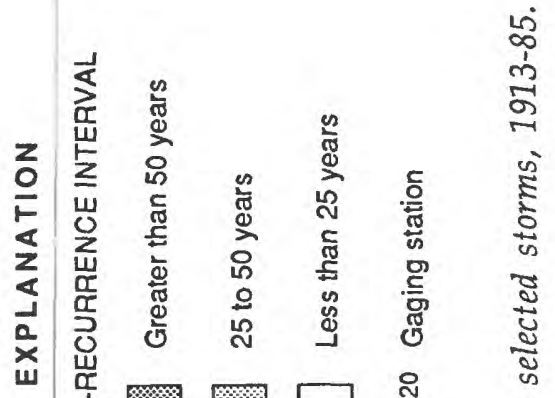

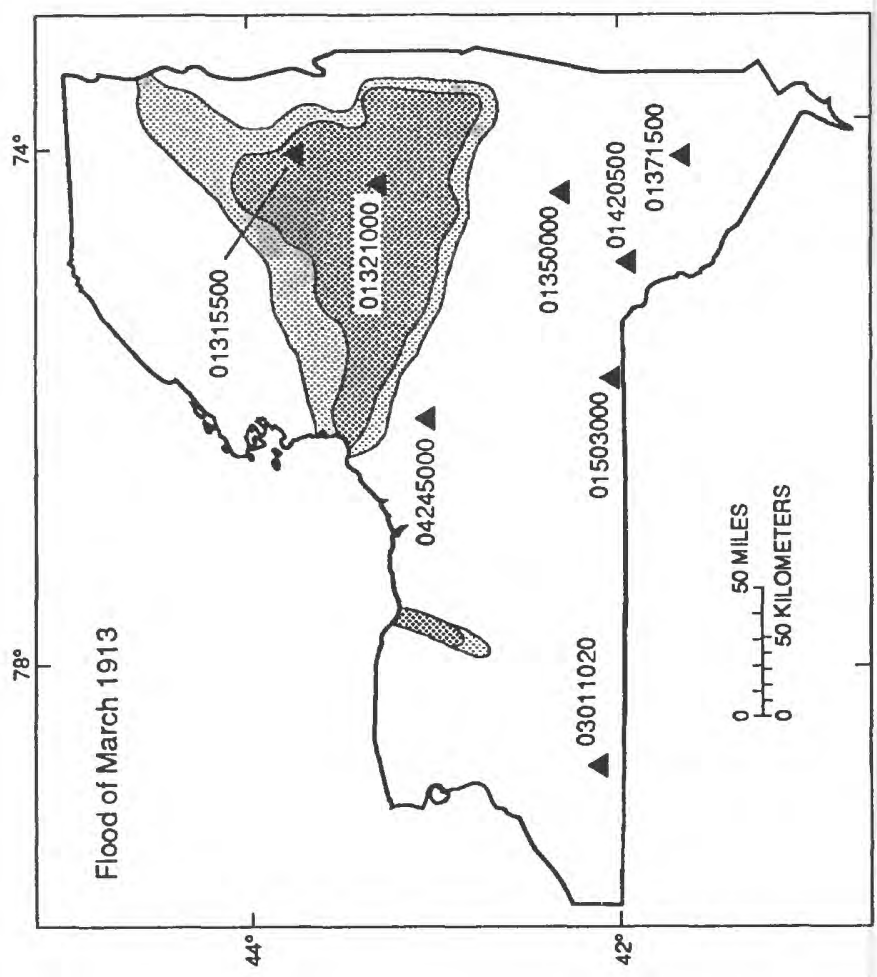

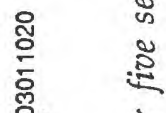
完

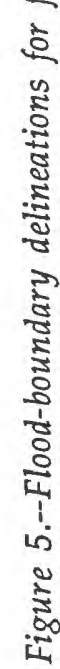



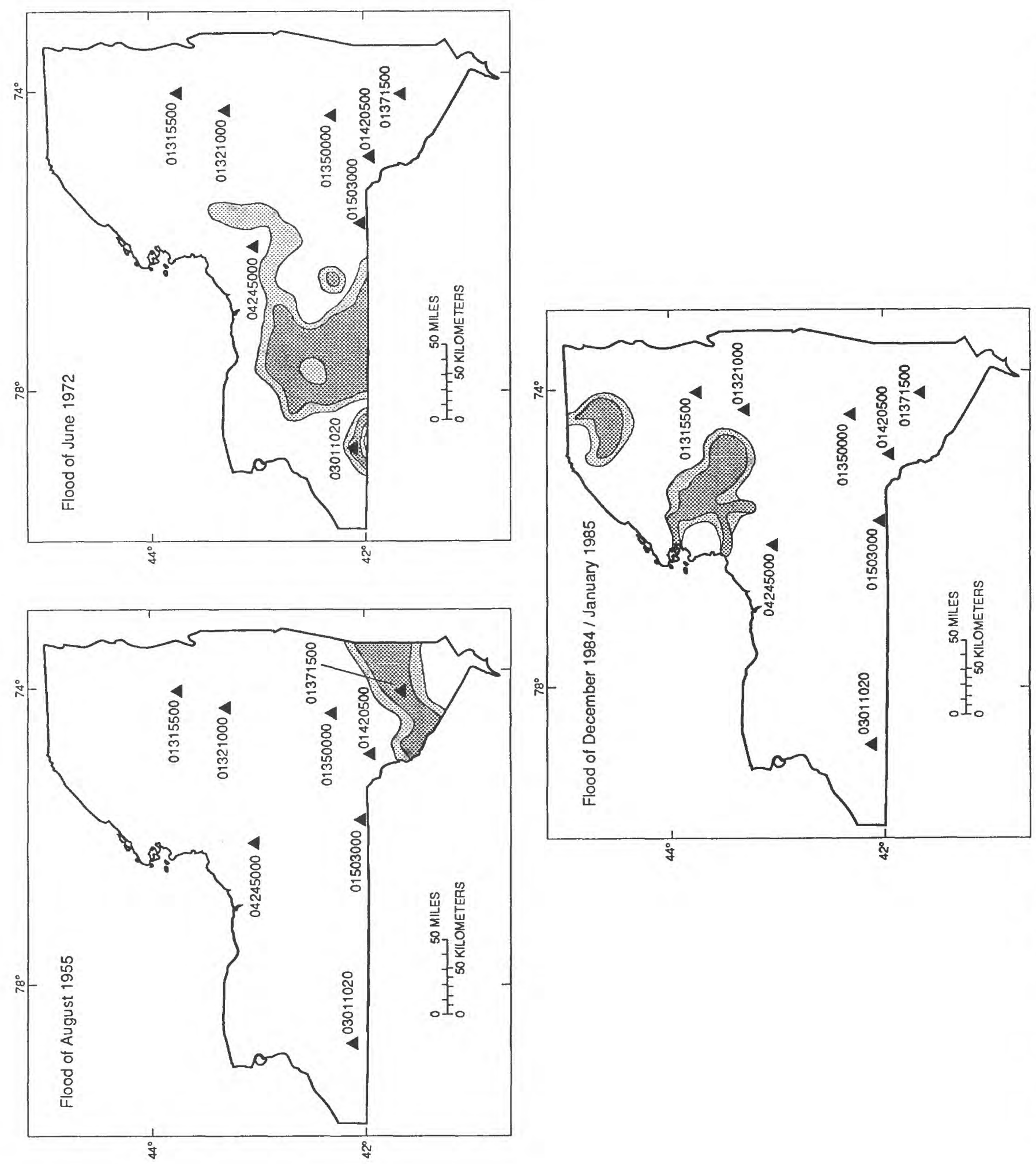

6 $\dot{0}$ . . ะ है 壳

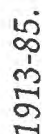
है

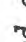
芩 . 


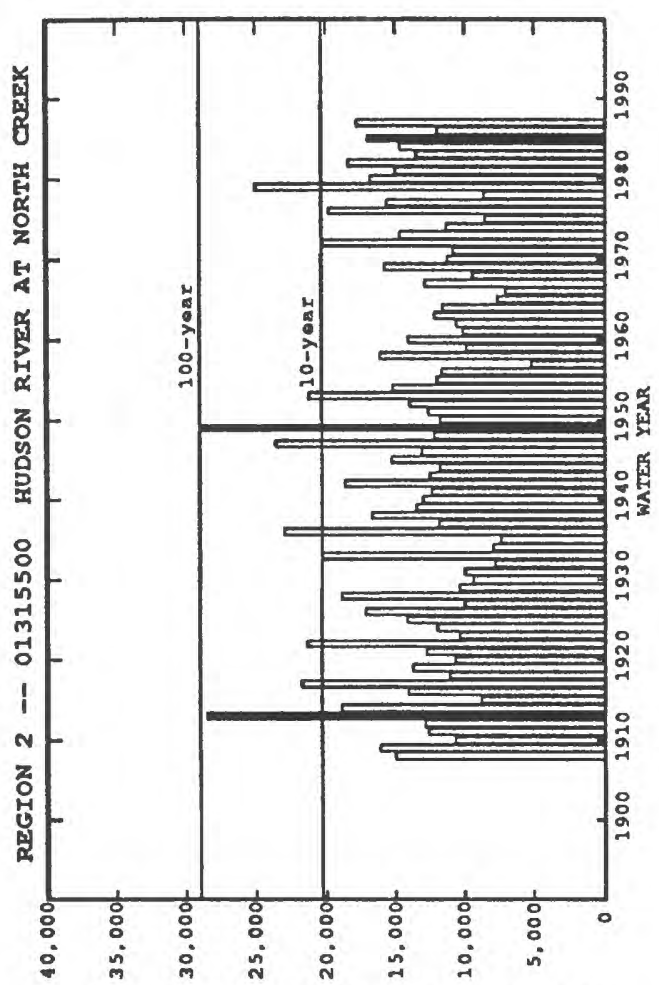

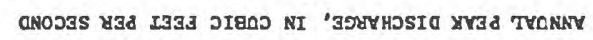

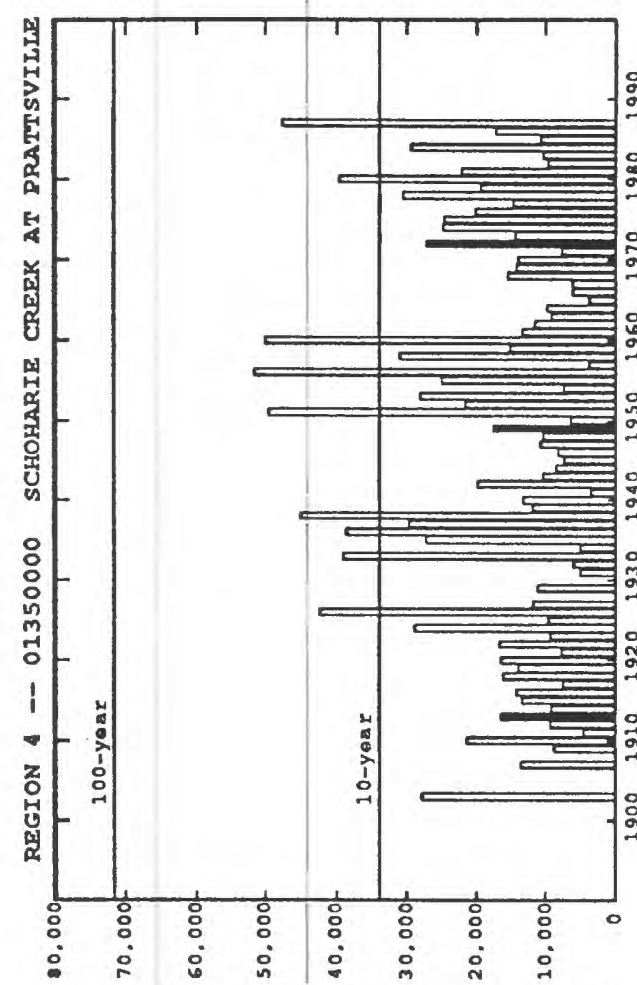

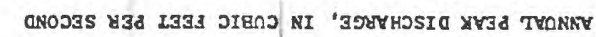
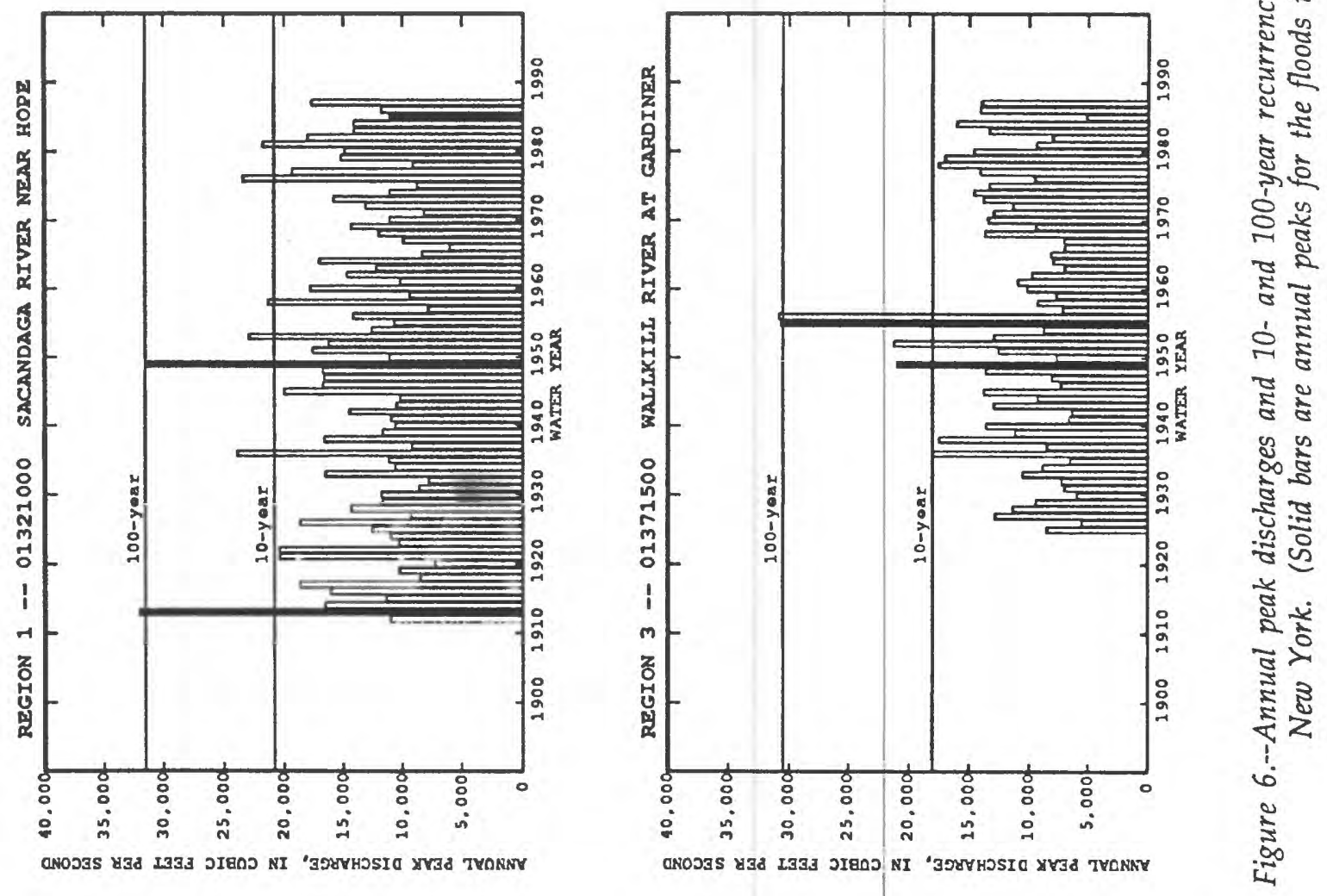


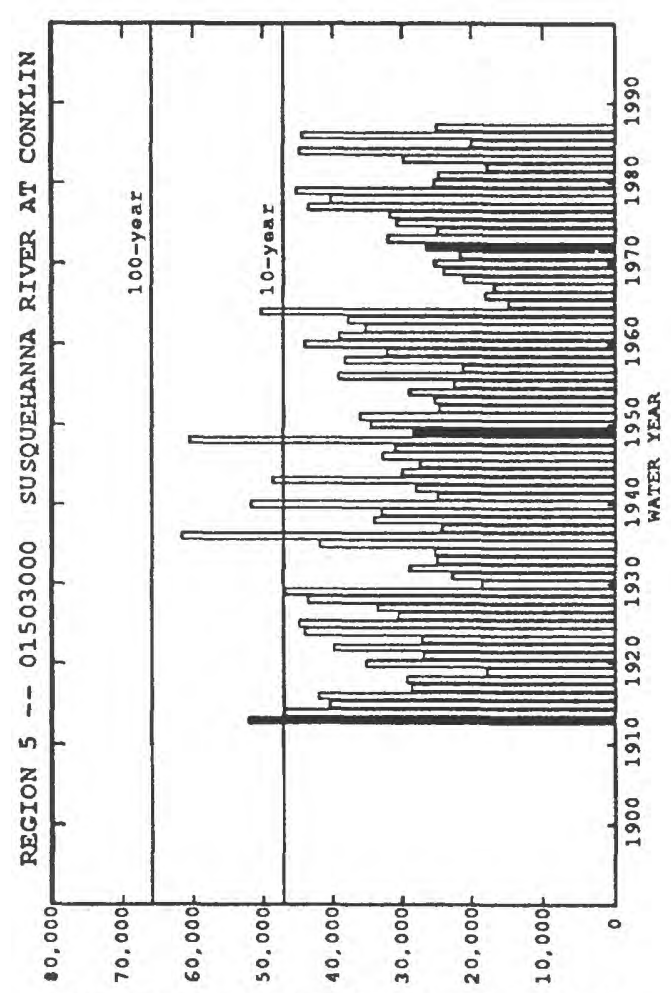

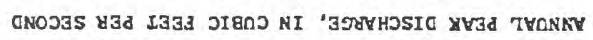

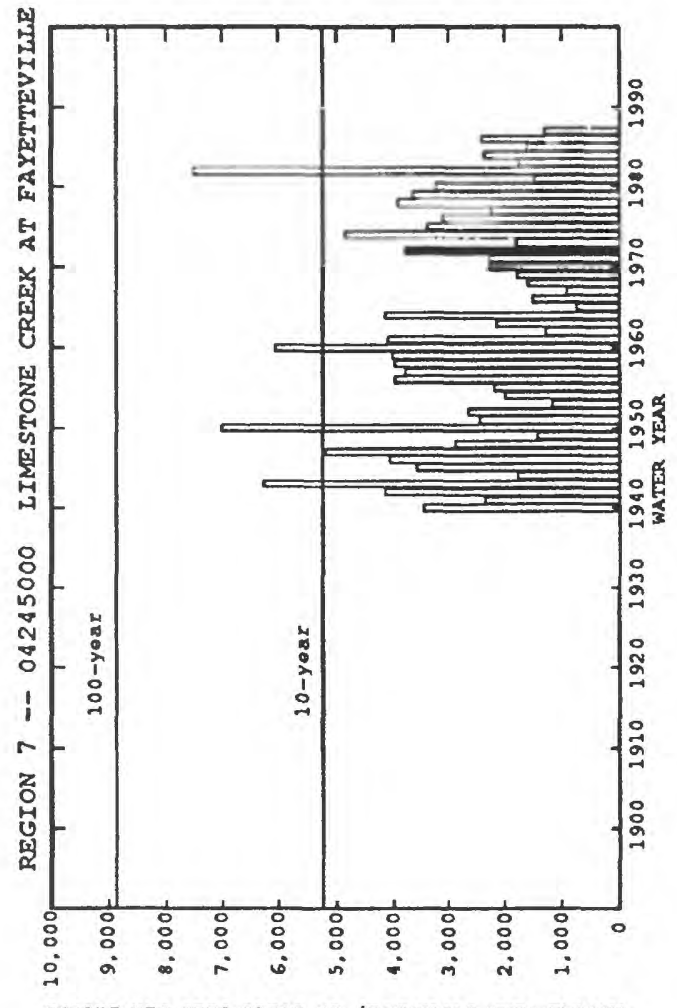

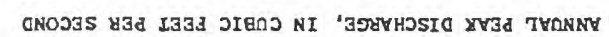

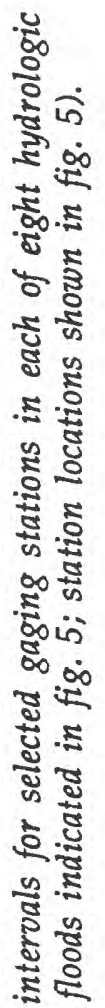

ั

है

호

는

호

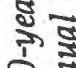

유 है

हีํ

을

롱

눙

डิ

혼

3

䔎之

尺

竞离

낭

เิ

$\infty$

$\frac{1}{5}$ 


\section{Basin Characteristics}

To transfer peak-discharge information to ungaged sites, multiple regression analysis was used to relate streamflow characteristics to selected topographic and climatic characteristics for each drainage basin. The following basin characteristics were tested for significance during regression analyses; those with abbreviations are the variables used in the final regression equations:

Drainage area (A), in square miles.--The area of a basin (watershed) upstream from the gage or site of interest delineated on 7.5- or 15-minute U.S. Geological Survey topographic maps and then determined by planimetering or digitizing the basin outline (Wagner, 1982).

Main channel stream length, in miles.--The distance measured along the main stream channel from the gage or point of interest to the drainage divide.

Main channel slope (SL), in feet per mile.--The difference in elevation (feet) between points 10 percent and 85 percent of the distance along the main stream channel from the gage or site of interest to the basin divide, divided by the distance (miles) between the two points.

Basin storage (ST), in percent.--The percentage of the total drainage area shown as lakes, ponds, and swamps as determined from 7.5- or 15-minute topographic maps by grid sampling, planimetering, or digitizing. Some basin storage values used in the study were obtained from the New York State Land Use and Natural Resources (LUNR) Inventory (Zembrzuski and Dunn, 1979).

Mean annual precipitation $(P)$, in inches.--The average value of mean annual precipitation over the basin of interest, determined from plate 1.

Average main stream channel elevation (EL), in feet.--The average of stream-channel elevations at points located 10 percent and 85 percent of the length of the main stream channel from the gage or point of interest to the drainage divide.

Basin forested area (F), in percent.--The percentage of the total drainage area shown as forest cover, as determined from 7.5- or 15-minute topographic maps by grid sampling, planimetering, or digitizing.

Basin shape index $(\mathrm{SH})$, in mile per mile.--The calculated ratio of the square of the main-channel stream length, in miles, to drainage area, in square miles (ratio of basin length to average basin width).

Precipitation intensity, in inches.--The average value of the maximum 24-hour precipitation over the basin with a recurrence interval of 2 years. (From U.S. Department of Commerce, 1961).

January minimum temperature, in degrees Fahrenheit.--The average value of the mean minimum January temperature over the basin, as determined from a National Oceanic and Atmospheric Administration (1980) map.

Mean basin elevation, in feet.--The average elevation of 20 equally spaced points over the basin as measured by a transparent grid from 7.5- or 15-minute topographic maps. This characteristic was tested for a subset of about three-fourths of the study basins.

Water equivalent of snow cover, in inches.--The average value of the mean water equivalent of snow cover over the basin for the first week of March, as determined from a map prepared by the U.S. Geological Survey (unpublished map on file in U.S. Geological Survey office in Albany, N.Y.).

The basin-characteristics data are stored in the U.S. Geological Survey National Water Storage and Retrieval System (WATSTORE) (Dempster, 1983). Selected basin characteristics for the gaging stations used in the analysis are listed in table 10 (at end of report).

\section{REGRESSION ANALYSIS}

Multiple regression analysis was used to develop the relations between peak discharges of selected recurrence intervals (dependent variable) and drainage-basin characteristics (explanatory variables). Previous regression analyses for New York used ordinary least squares (OLS) methods (Zembrzuski and 
Dunn, 1979). The OLS estimates are appropriate when all onsite flow estimates are equally reliable, the natural variability is the same for each site, and observed concurrent flows at every pair of sites are independent. In practice, the analyst usually does not have such a uniform set of data with which to work.

Recent research by Stedinger and Tasker (1985) and Tasker and Stedinger (1989) indicates that generalized least squares (GLS) may be more appropriate for hydrologic regression than OLS. In this approach, the regression coefficients are estimated by taking into consideration the time-sampling error (length of record at each site) and the cross correlation of annual peak-discharges between sites. The above research has shown that the GLS technique was superior to OLS when streamflow data were cross correlated and(or) of differing record lengths.

In GLS regressions, each watershed in the analysis is weighted in accordance with the variance (time-sampling error) and spatial correlation structure of the streamflow characteristic (annual peak discharges). In addition, the time-sampling error in the streamflow characteristic is accounted for when the accuracy of the regression equation is evaluated. The prediction error for ungaged sites is partitioned into model error (error in assuming an incomplete model form) and sampling error (including both time- and spatial-sampling errors). The model error cannot be reduced by additiona! data collection, but the sampling error can be reduced through extended operation of existing stations or installation of new stations, or some combination of both.

For the GLS regression analysis used in this study, logarithmic (base 10) transformations were made on all streamflow and basin characteristics to obtain a constant variance of the residuals about the regression line, and to linearize the relation between the dependent variable (peak-discharge) and explanatory variables (basin characteristics) for linear least-squares regression techniques. The multiple-regression equations based on logarithmic transformation of the variables are of the form:

$$
\log _{10} Y=b_{0}+b_{1} \log 10 X_{1}+b_{2} \log _{10} X_{2}+\ldots . .+b_{n} \log _{10} X_{n}
$$

or, after taking antilogs,

where:

$$
Y=10^{b_{0}}\left(X_{1}^{b_{1}}\right)\left(X_{2}^{b_{2}}\right) \ldots . .\left(X_{n}^{b_{n}}\right)
$$

$$
\begin{aligned}
Y & =\text { dependent variable (peak-discharge for selected recurrence interval) } \\
X_{1} \text { to } X_{n} & =\text { explanatory variables (basin characteristics) } \\
b_{0} \text { to } b_{n} & =\text { regression model coefficients estimated through GLS procedures }
\end{aligned}
$$

Selection of final explanatory variables for each model was based on stepwise regression algorithms and all-possible-subsets regression (SAS Institute, 1982; Minitab, 1985). Final regression equations were selected on the basis of several factors, including: standard error of the estimate, Mallow's $C p$ statistic, statistical significance of the explanatory variables, $r^{2}$ (coefficient of determination), ease of measurement of explanatory variables, and the PRESS statistic (an index of the prediction error associated with the regression equation). Multicollinearity in the regression models was assessed by the VIF (variance inflation factor) and the correlation between explanatory variables.

\section{REGIONALIZATION OF FLOOD-FREQUENCY ESTIMATES}

Regression analysis provides a means of relating peak discharge to basin characteristics. Variability of the relation between peak discharge and basin characteristics among gaged sites can be reduced by regionalization, a process in which an area is divided into hydrologic regions to account for regional differences in peak-discharge response and in topographic and climatic variables that affect streamflow. Hydrologic regions refer to areas in which streamflow-gaging stations indicate a similarity of peak-discharge response that differs from the peak-discharge response in adjacent regions. These similarities and differences are defined by the regression residuals, which are the differences between the peak discharges calculated from station records and the values computed through the regression equation. 


\section{Delineation of Hydrologic Regions}

The initial step toward delineating hydrologic regions was to develop a statewide regression equation through OLS( ordinary least-squares) analysis. Significant explanatory variables for the statewide model (equation) included drainage area, main-channel slope, basin storage, mean annual precipitation, and March water-equivalent of snow cover. The dependent variable for the statewide regression was the 50-year peak discharge.

Hydrologic regions within New York were delineated primarily through inspection of the areal distribution of the statewide regression residuals. Regions where the regression equation consistently overestimated or underestimated the peak-discharge response were delineated as separate hydrologic regions, and separate GLS regression equations were developed to estimate peak discharges in each region. (Originally seven regions were delineated for New York, but because residuals for region 4 , in the Catskill Mountain area, indicated need for an additional division, region 4 was divided into hydrologic regions 4 and 4A.) Regional differences in geologic and physiographic conditions were also considered during hydrologic-region delineation. Generally, the hydrologic-region boundaries coincide with drainage-basin divides; the resulting delineations are shown on plate 2.

The distribution of regression residuals for each hydrologic region before and after regionalization are shown in box plots in figure 7. The upper plot summarizes the results of the statewide regression and indicates the clustering of residuals within the final eight hydrologic regions before regionalization; the lower plot shows the distribution of the final GLS regression residuals for the eight hydrologic regions of New York. The 50-year peak-discharge was the dependent variable for this analysis.

To further evaluate the delineations of the hydrologic regions, the Wilcoxon Signed Ranks test (Iman and Conover, 1983) was used to compare residuals between regions (Tasker, 1982). This method tests the statistical significance of a cluster of regression residuals. The test hypothesis is that the median residual in a hydrologic region is not significantly different from the median residual for the entire State (which is zero). Delineation of an area as a separate hydrologic region is supported if the test hypothesis is rejected. Results of the test are summarized in table 1.

The median residual in six of the eight hydrologic regions was different from zero at a probability level less than 0.001 . The median residuals for the other two regions ( 3 and $4 \mathrm{~A}$ ) were not significantly different from zero, but the sign and magnitude of the residuals, differences in topographic and geologic conditions, and hydrologic judgment indicated delineation of these areas as separate hydrologic regions.

Table 1.--Results of Wilcoxon Signed Ranks test on the 50-year peak-discharge regression residuals for eight hydrologic regions in New York

[Hydrologic regions are delineated in pl. 2. < = less than. $\mathrm{ft}^{3} / \mathrm{s}=$ cubic feet per second.]

\begin{tabular}{ccccccc}
\hline $\begin{array}{c}\text { Hydrologic } \\
\text { region }\end{array}$ & $\begin{array}{c}\text { Median of } \\
\text { residuals } \\
\text { (logarithms of } \\
\mathrm{ft}^{3} / \mathrm{s} \text { ) }\end{array}$ & $\begin{array}{c}\text { Sum of } \\
\text { positive } \\
\text { ranks } \\
\text { (percent of } \\
\text { total) }\end{array}$ & $\begin{array}{c}\text { Sum of } \\
\text { negative } \\
\text { ranks } \\
\text { (percent of } \\
\text { total) }\end{array}$ & $\begin{array}{c}\text { Observed peak } \\
\text { discharge } \\
\text { relative to } \\
\text { predicted peak } \\
\text { discharge }\end{array}$ & $\begin{array}{c}\text { Probability } \\
\text { level }\end{array}$ & $\begin{array}{c}\text { Number } \\
\text { of stations }\end{array}$ \\
\hline 1 & & & & & & \\
2 & +0.090 & 97 & 3 & High & $<0.001$ & 31 \\
3 & -.102 & 7 & 93 & Low & $<.001$ & 49 \\
4 & -.052 & 39 & 61 & Low & 218 & 42 \\
$4 \mathrm{~A}$ & +.151 & 99 & 1 & High & $<.001$ & 23 \\
5 & +.027 & 54 & 46 & High & .813 & 17 \\
6 & -.090 & 11 & 89 & Low & $<.001$ & 48 \\
7 & +.117 & 86 & 14 & High & $<.001$ & 73 \\
\hline
\end{tabular}



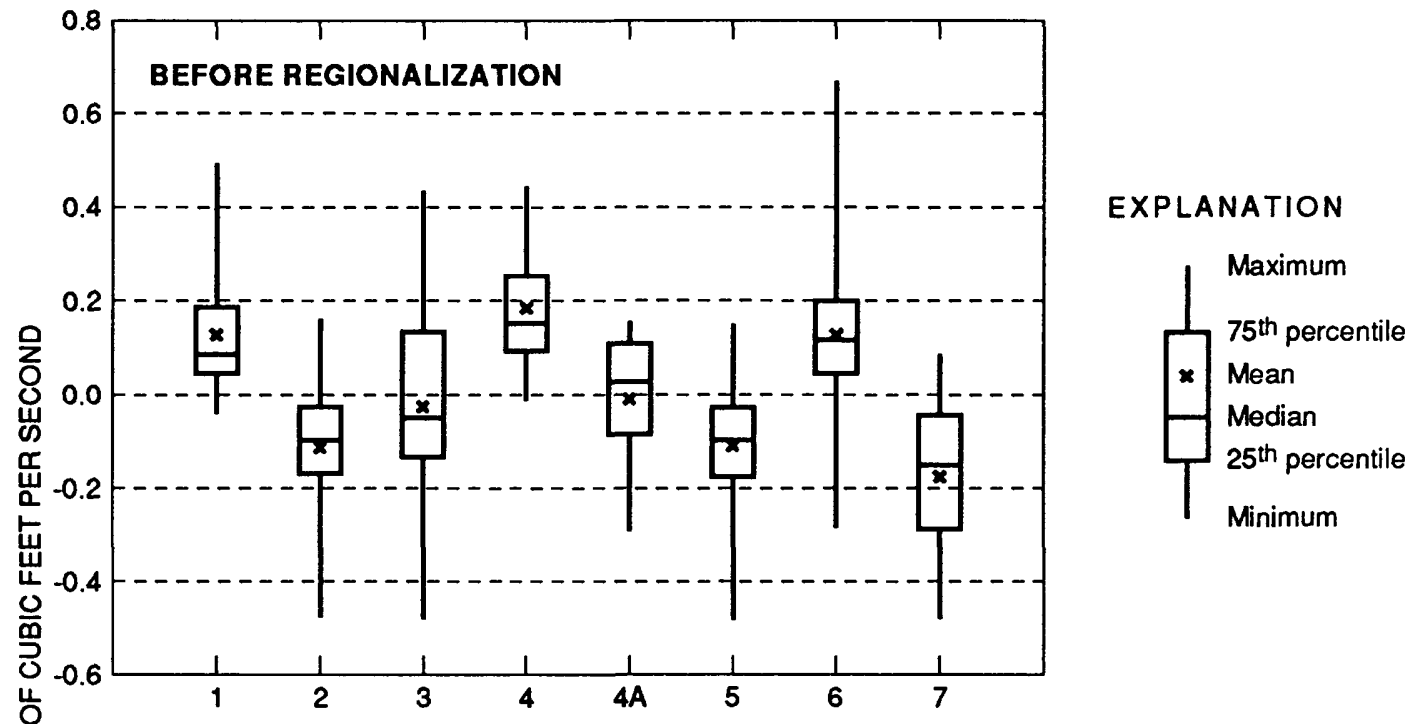

Figure 7.

Comparison of 50-year peakdischarge residuals from the statewide regression for gaging stations within eight hydrologic regions of New York, before and after egionalization. (Locations of regions are shown on pl. 2)

\section{Regional Basin and Peak-Discharge Characteristics}

To summarize and evaluate differences between hydrologic regions, basin and peak-discharge characteristics were compared among regions (figs. 8-12). Box plots in figures 8 and 9 summarize regional basin and peak-discharge characteristics, respectively. Explanatory variables from the regional and statewide regressions are included in figure 8; regional statistical summaries of annual peak-discharge data used in the analysis as well as regional 50-year peak-discharge runoff rates are given in figure 9.

Regions 4 and $4 \mathrm{~A}$ include basins with the greatest main channel slopes (fig. 8B) and mean annual precipitation (fig. 8D), and regions 1 and 3 have the greatest basin-storage values (fig. 8C). Basinshape index values are greatest for basins in regions 1 and 7 (greater basin elongation); basins in region $4 \mathrm{~A}$ tend to be rounded, as indicated by the low index values (fig. $8 \mathrm{H}$ ). 

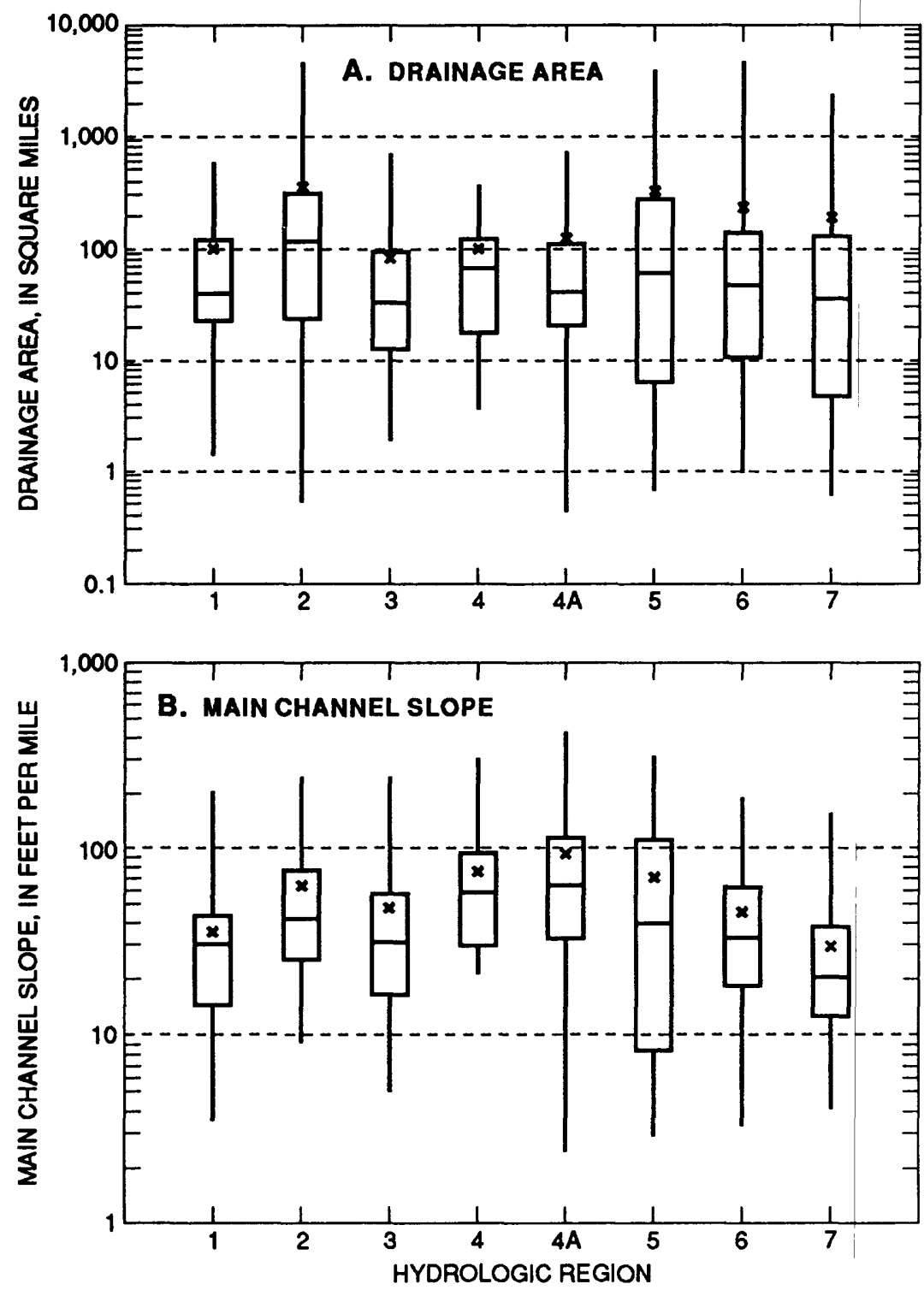

\section{EXPLANATION}

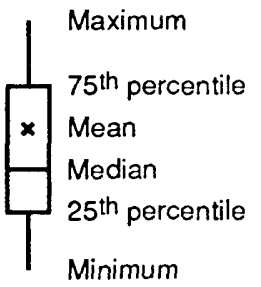

Figure 8.

Comparison of selected basin characteristics for gaging stations within eight hydrologic regions of New York. (Locations of regions are shown on pl. 2)

A. Drainage area.

B. Main channel slope.

The statistics of annual peak discharges (fig. 9) show that the greatest mean (fig. 9A) and standard deviations (fig. 9B) for basins used in the study are in hydrologic region 4, as is the maximum 50-year peak-discharge runoff rate (fig. 9F). Basins within regions 2 and $4 \mathrm{~A}$ have the greatest median number of years of annual peak-discharge record, whereas those in regions 1 and 7 have the least (fig. 9E).

The distribution of gaging stations by length of period of annual peak-discharge record and by drainage-area size is shown in figure 10. Region 2 has the most stations with long-term record (greater than 55 years), and region 7 has none (fig. 10A). Region 5 and 6 have the greatest number of stations with drainage areas less than $15 \mathrm{mi}^{2}$, and region 4 had no basins greater than $386 \mathrm{mi}^{2}$ (fig. 10B).

As an indication of the seasonality of floods, a comparison of the monthly frequency of annual peak discharges for each hydrologic region and for New York was made (figs. 11, 12). Most annual peakdischarges for each hydrologic region and for all ranges of drainage area occur in March and April. (Note again that these graphs include data from 29 out-of-State gaging stations.) 

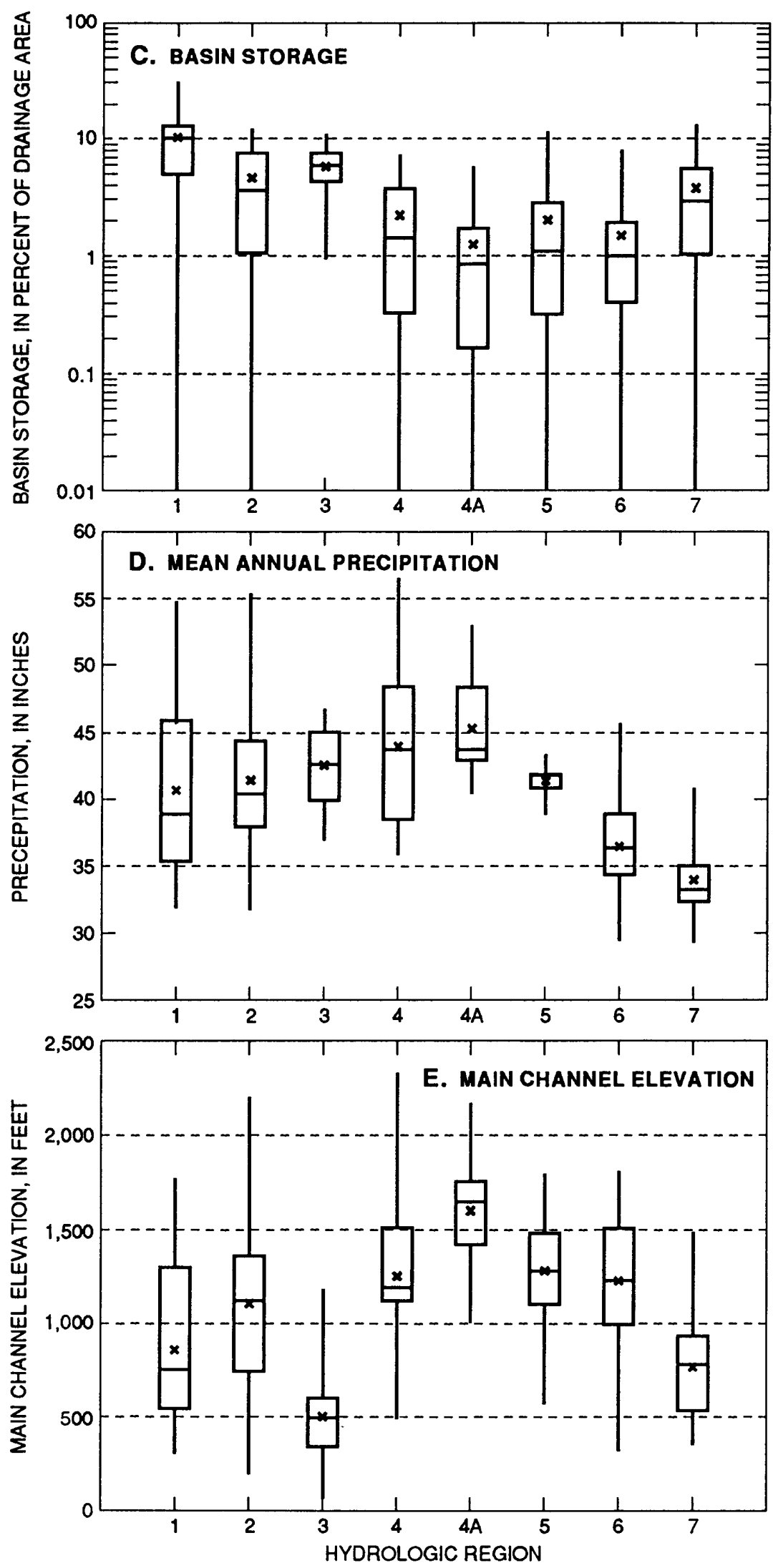

EXPLANATION

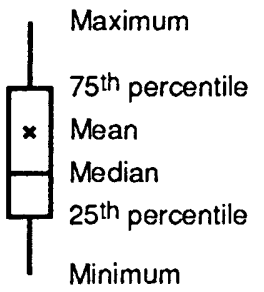

Figure 8 (continued).

Comparison of selected basin characteristics for gaging stations within eight hydrologic regions of New York. (Locations of regions are shown on pl. 2)

C. Basin storage

D. Mean annual precipitation

E. Main channel elevation 

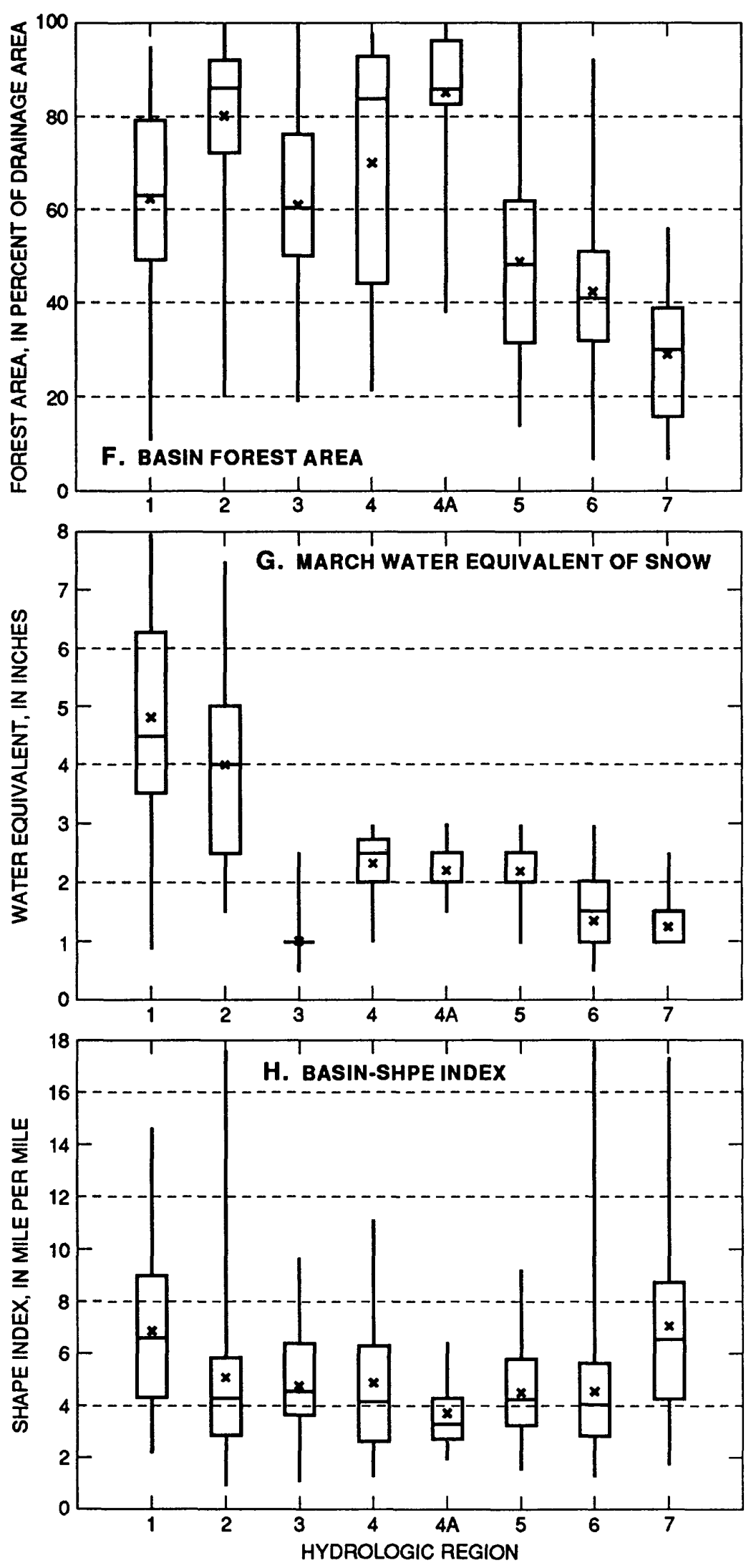

EXPLANATION

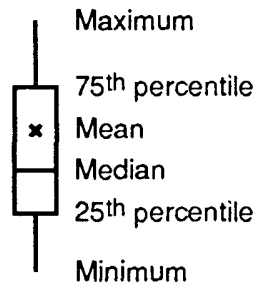

Figure 8 (continued).

Comparison of selected basin characteristics for gaging stations within eight hydrologic regions of New York. (Locations of regions are shown on pl. 2)

F. Basin forest area

G. March water equivalent of snow

H. Basin shape index 

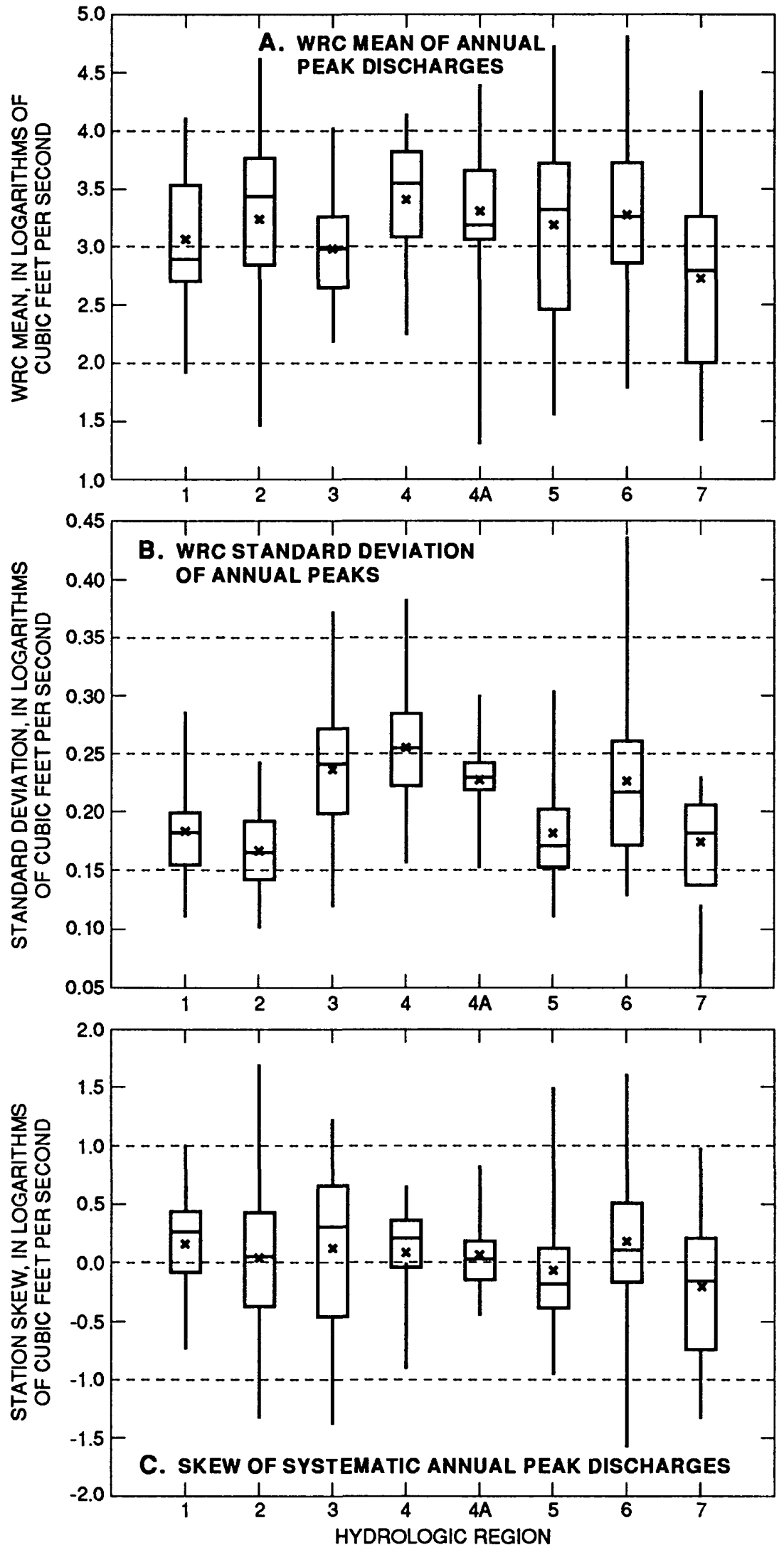

EXPLANATION

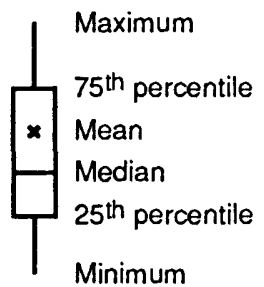

Figure 9.

Comparison of selected peakdischarge characteristics for gaging stations within eight hydrologic regions of New York. (Locations of regions are shown on pl. 2)

A. Mean of annual peak discharges based on Water Resources Council (WRC) guidelines (1981).

B. WRC standard deviation of annual peak discharges.

C. Skew of systematic annal peak discharges. 

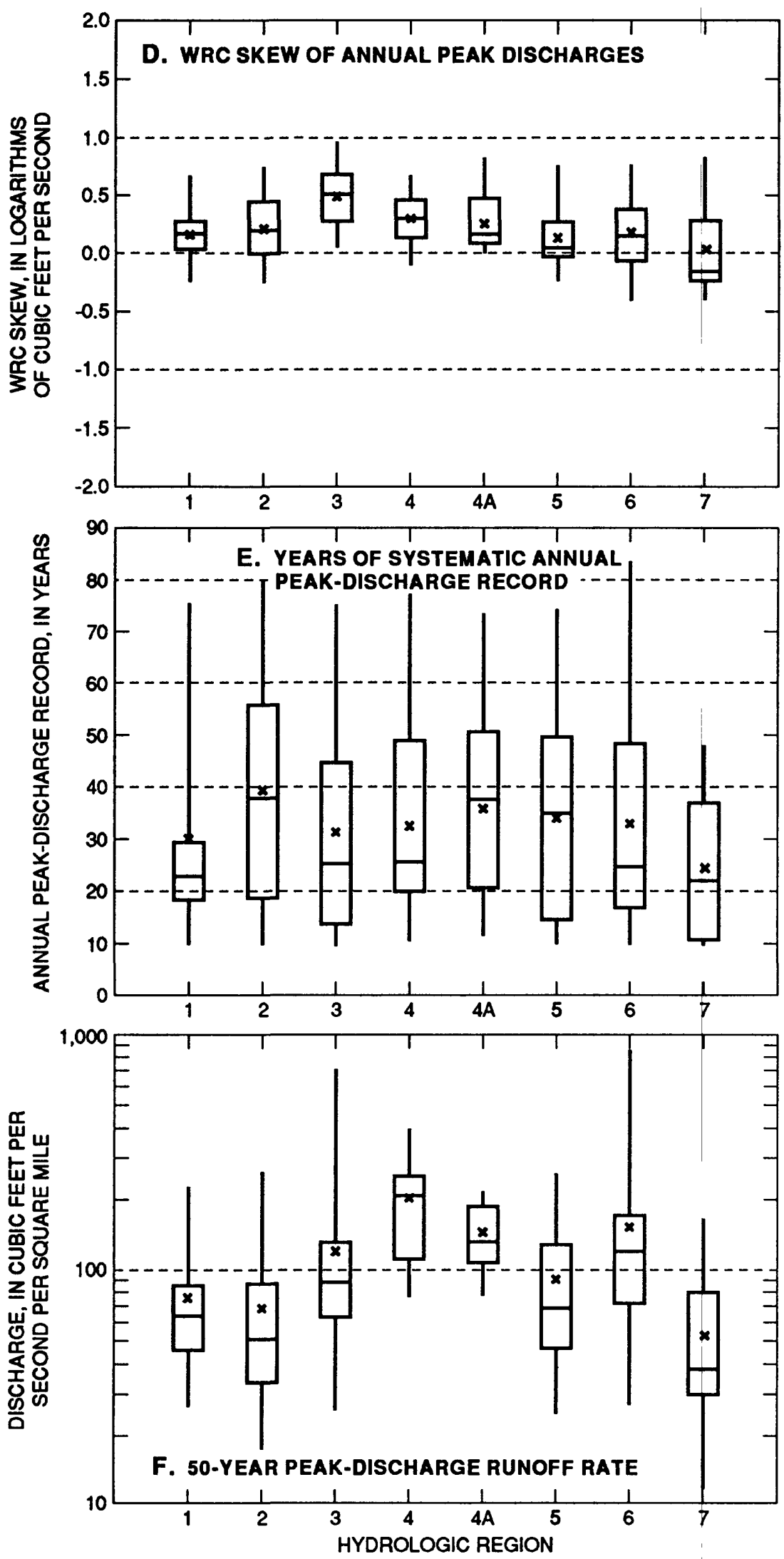

\section{EXPLANATION}

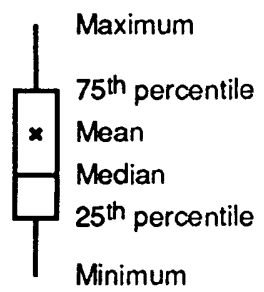

Figure 9 (continued).

Comparison of selected peakdischarge characteristics for gaging stations within eight hydrologic regions of New York. (Locations of regions are shown on pl. 2)

D. WRC skew of annual peak discharges.

E. Years of systematic annual peak-discharge record.

F. 50-year peak discharge runoff rate. 

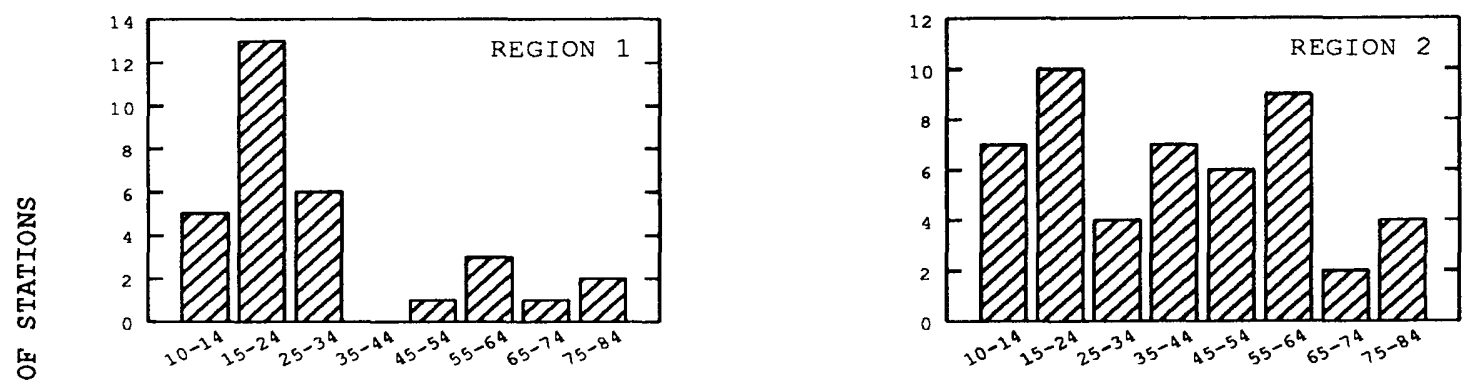

舀
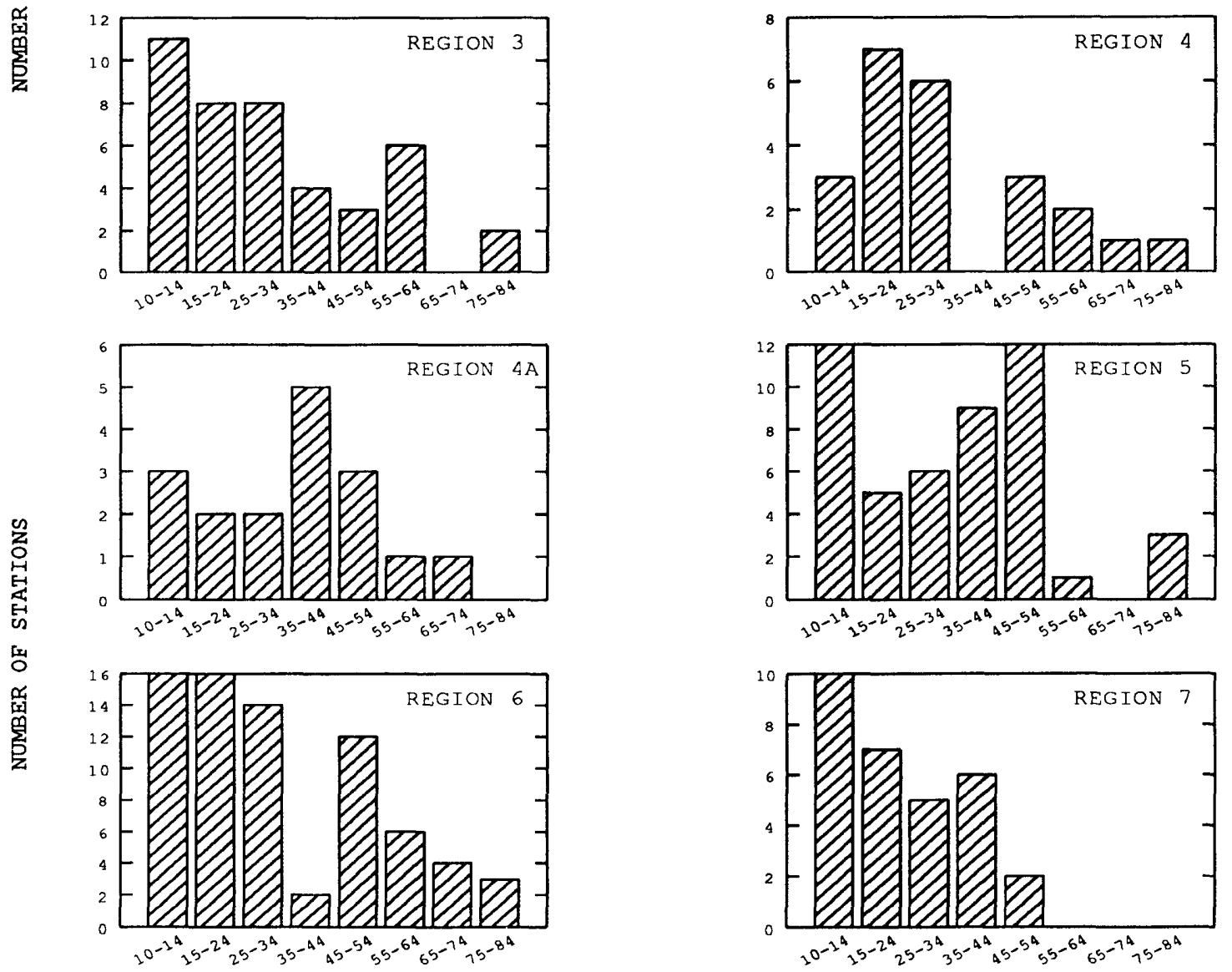

STATION RECORD IENGTH, IN YEARS
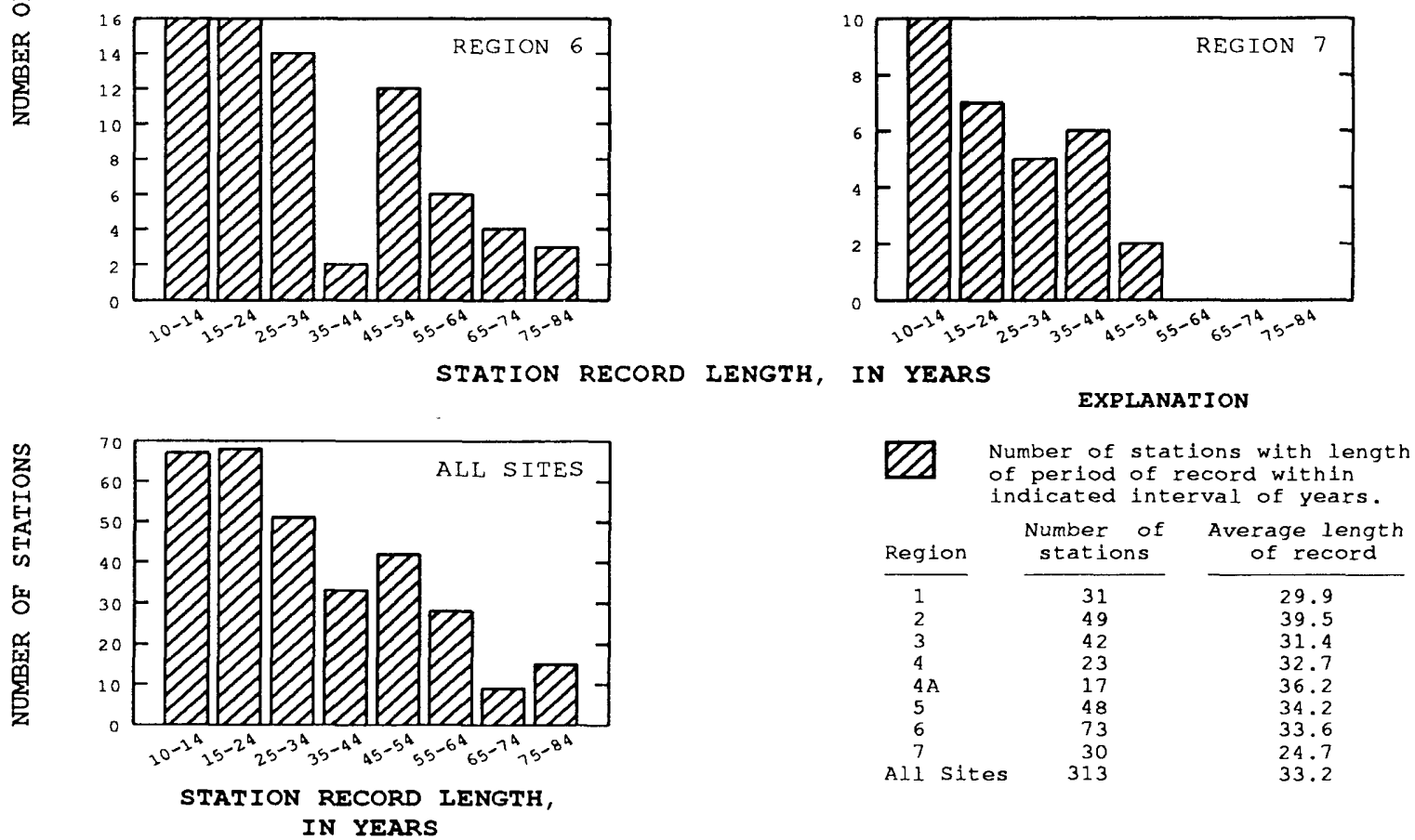

Figure 10A.--Distribution of stations, by length of period of record, within each of the eight hydrologic regions in New York and for all stations combined. (Locations of regions are shown on pl. 2). 


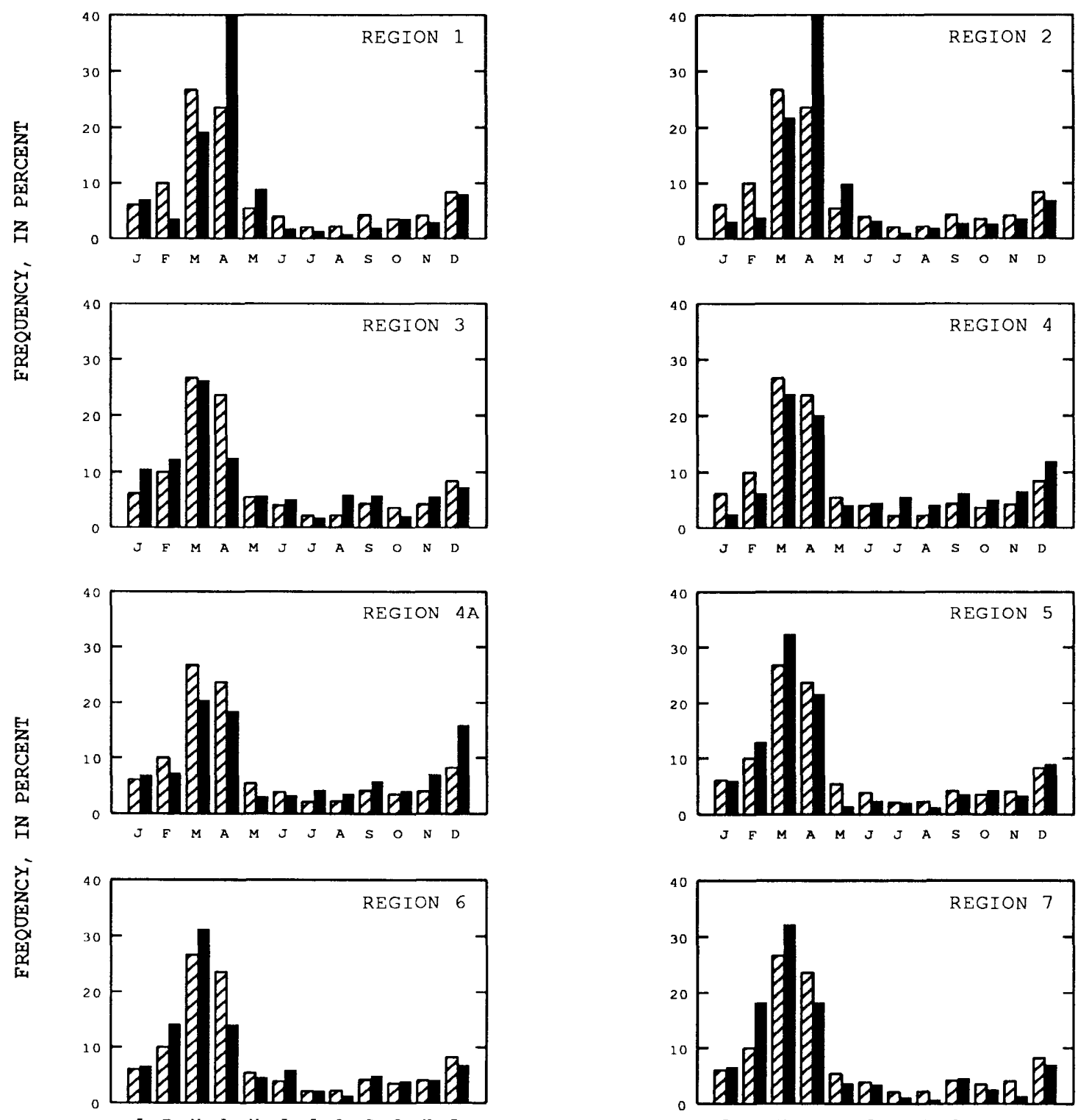

MONTH OF YEAR

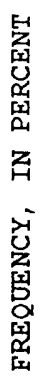
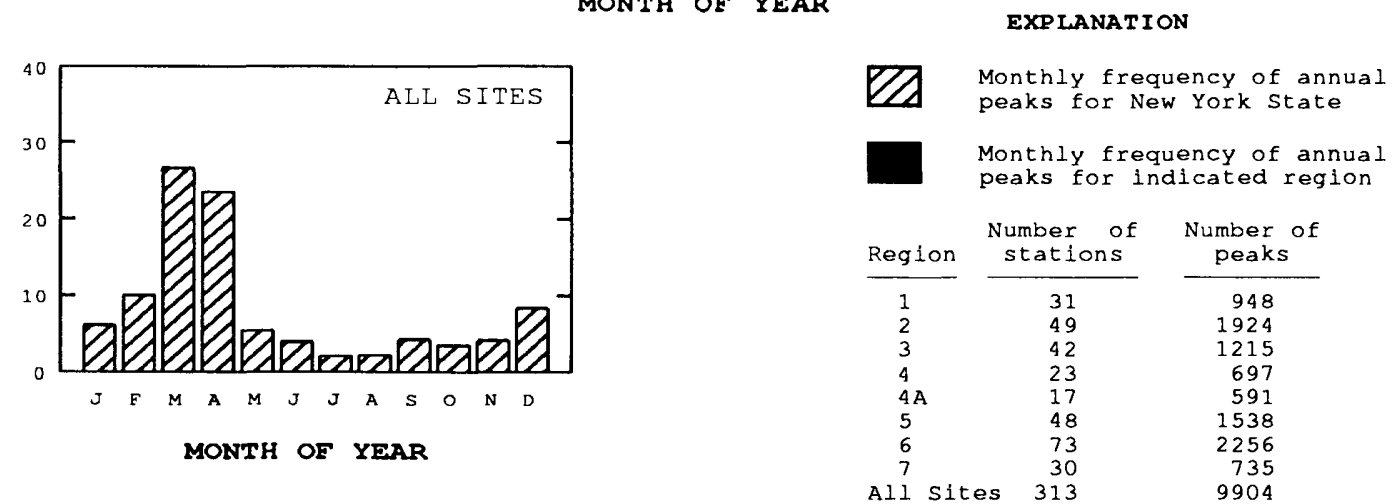

Figure 11.--Comparison of the monthly frequency of annual peak flows within each of the eight hydrologic regions in New York and for all stations combined. (Locations of regions are shown on pl. 2). 

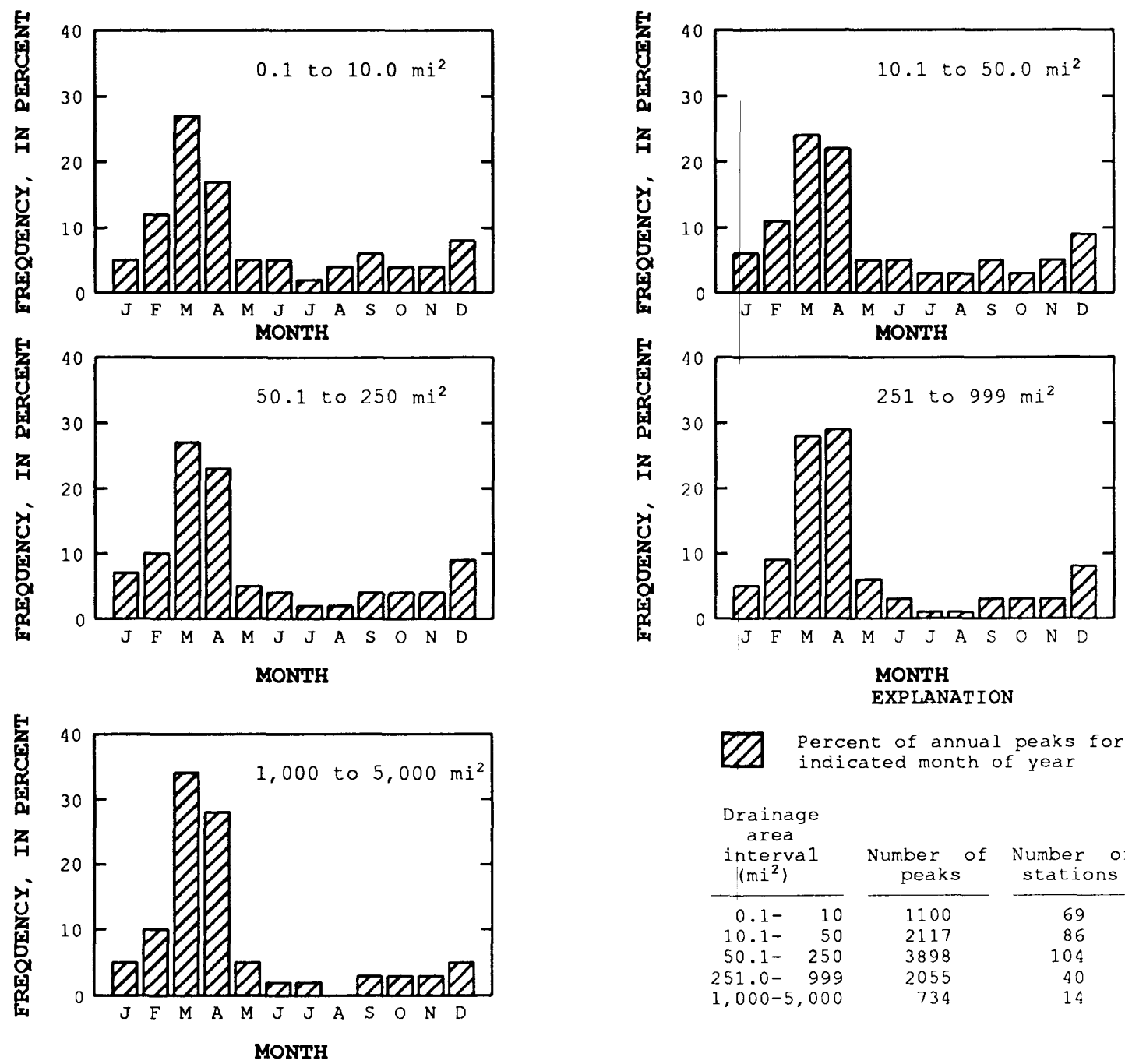

77 Percent of annual peaks for indicated month of year

\begin{tabular}{crcc}
$\begin{array}{c}\text { Drainage } \\
\text { area } \\
\text { interva1 } \\
\left.\text { (mi }{ }^{2}\right)\end{array}$ & $\begin{array}{c}\text { Number of } \\
\text { peaks }\end{array}$ & $\begin{array}{c}\text { Number of } \\
\text { stations }\end{array}$ \\
\hline $0.1-$ & 10 & 1100 & 69 \\
$10.1-$ & 50 & 2117 & 86 \\
$50.1-$ & 250 & 3898 & 104 \\
$251.0-$ & 999 & 2055 & 40 \\
$1,000-5,000$ & 734 & 14
\end{tabular}

Figure 12.--Monthly frequency of annual peak flows at gaging stations used in the study, for selected drainage-area sizes.

\section{REGIONAL REGRESSIONS}

Regression equations were developed for each of the eight hydrologic regions from (1) all statistically significant explanatory variables (full regression equations) and (2) drainage area only. GLS procedures were used for all regional-regression analyses.

\section{Full-Regression Equations}

Regression equations to estimate peak discharges with recurrence intervals of $2,5,10,25,50,100$, and 500 years in each of the eight hydrologic regions, developed through GLS procedures, are presented in table 2. Also included in table 2 are estimates of the standard error of prediction and equivalent years of record for each regression equation (Hardison, 1971). The prediction error indicates the expected accuracy of the regression equations when applied to ungaged sites not used in the regression analyses. Peak-discharge estimates for ungaged sites should be within one standard error (of prediction) of the true value about 68 percent of the time. An additional overall measure of predictive ability of the models is the equivalent years of record (table 2). Equivalent years of record is a function 
of the average variability and skew of the annual peak-discharge series at sites in a hydrologic region, the accuracy of the regression equation, and the recurrence interval in question (Tasker and Stedinger, 1989). Equivalent years of record represent the number of years of gage data required to achieve results with accuracy comparable to that given by the regression equations. Regression estimates used to determine peak discharge at gaged sites and at ungaged sites near gaged sites are weighted by the equivalent years of record for the equation. (See section "Computations of peak discharge.")

A summary of the full-regression equations is given in table 3 (p. 28). The standard error of estimate for the regional models ranges from 10 to 43 percent. (Standard error of estimate is a measure of how well the sample data fit the relation derived through a regression analysis.) Table 3 also includes statistically significant explanatory variables for the regional equations. Several of the variables require addition or subtraction of constants before the equation is applied. These constants were determined through sensitivity analyses, normality of the distribution of a variable within its region, improvement in standard error of estimate, coefficient of determination $\left(r^{2}\right)$, and the PRESS statistic (an index for prediction error).

The equations in table 2 were developed from logs (base 10) of the variables to help linearize the relations. To make the equation useful for prediction requires a detransformation; taking the antilog of the predicted logarithm of peak-discharge results in an estimate of the median response rather than the mean (Choquette, 1988). Biased estimates can result; therefore, a bias-correction factor was computed for each equation in table 2 and is presented in table 4 (p. 28). These factors, which range from 1.005 to 1.088 , are based on the standard error of estimate of each equation, and, when the regression estimate is multiplied by the bias-correction factor, the resultant discharge will correspond to the mean value expected for the particular set of variables in question (Koch and Smillie, 1986). The mean value will be a more conservative estimate than the median value in terms of minimizing risk of flood damage. Use of the bias-correction factor is left to the discretion of the user. The factor was not applied to data in any tables or examples used in this report.

The final generalized least squares (GLS) full equations (table 2) were compared with equations previously developed for New York by Zembrzuski and Dunn (1979). The 50-year estimating equation from each study was applied to stations within each of the eight hydrologic regions, and residuals were computed. The sum of the squares of the GLS residuals were in each case significantly less than those derived through the Zembrzuski and Dunn equation, which indicates that the GLS equations are more accurate. As a further comparison of the two sets of equations, observed 50-year peak discharges were plotted against predicted values for stations within each of the eight hydrologic regions computed from both sets of equations (fig. 13A, 13B). The 1979 equations showed significant bias and error for several of the regions (fig. 13A); they gave a general underprediction for sites in hydrologic regions 1 and 4 and a significant overprediction for sites in regions 2,5, and 7 . This bias and error can be attributed to the smaller number of stations, shorter periods of record, and the use of only three hydrologic regions in the 1979 study. The GLS results from this study (fig. 13B) are based on improved statistical methods that were unavailable during the 1979 work and indicate no significant bias and less error.

\section{Drainage-Area-Only Equations}

Alternative GLS regression equations for each of the eight hydrologic regions that contain only the most significant basin characteristic (drainage area) and have higher standard errors than the GLS full-regression equations are given in table 5 (p. 29). An indication of their accuracy is shown in figure 13C. The observed and predicted 50-year peak discharges are given for the drainage-area-only equations (table 5) and also for the GLS full-regression equations (table 2) for comparison. The illustration shows no significant bias for the drainage-area-only relations, but generally more error. Bias-correction factors, standard errors of prediction, and equivalent years of record are included in table 5 .

The drainage-area-only equations (table 5 ) are intended to provide estimates of peak discharges that are easier to calculate, although less accurate, than those computed by the full equations. The drainage-area exponents for each region (table 5) can be useful in transferring peak-discharge information upstream or downstream from a gaged site according to the ratio of the ungaged site's drainage area to the gaged site's drainage area, raised to the exponent power (Wandle, 1983). 
Table 2.--Full-regression equations for estimating peak discharges for streams in each of eight hydrologic regions of New York.

[A = Drainage area, in square miles, $\mathrm{SL}=$ main channel slope, in feet per mile, $\mathrm{ST}=$ basin storage, in percent, $\mathbf{P}=$ mean annual precipitation, in inches, $\mathbf{F}=$ basin forested area, in percent, EL = average main stream channel elevation, in feet, and, $\mathrm{SH}=$ basin-shape index, in mile per mile. Region locations are shown on pl. 2]

\begin{tabular}{c|c}
\hline Regression equation & $\begin{array}{c}\text { Standard error of } \\
\text { prediction } \\
\text { (percent) years of record }\end{array}$ \\
\hline
\end{tabular}

\section{REGION 1}

\begin{tabular}{|c|c|}
\hline $\mathrm{Q}_{2}=34.9(\mathrm{~A})^{0.909}(\mathrm{ST}+5)^{-0.489}(\mathrm{P}-20)^{1.047}(\mathrm{~F}+10)^{-0.420}$ & 21.1 \\
\hline $\mathrm{Q}_{5}=84.4(\mathrm{~A})^{0.890}(\mathrm{ST}+5)^{-0.513}(\mathrm{P}-20)^{0.984}(\mathrm{~F}+10)^{-0.466}$ & 20.9 \\
\hline$Q_{10}=130 .(A)^{0.881}(S T+5)^{-0.526}(P-20)^{0.961}(F+10)^{-0.490}$ & 21.2 \\
\hline$Q_{25}=197 .(A)^{0.872}(S T+5)^{-0.538}(P-20)^{0.937}(F+10)^{-0.506}$ & 22.2 \\
\hline$Q_{50}=250 .(A)^{0.868}(S T+5)^{-0.544}(P-20)^{0.919}(F+10)^{-0.510}$ & 23.4 \\
\hline $\mathrm{Q}_{100}=306 .(\mathrm{A})^{0.864}(\mathrm{ST}+5)^{-0.548}(\mathrm{P}-20)^{0.899}(\mathrm{~F}+10)^{-0.508}$ & 24.7 \\
\hline $\mathrm{Q}_{500}=441 .(\mathrm{A})^{0.858}(\mathrm{ST}+5)^{-0.553}(\mathrm{P}-20)^{0.853}(\mathrm{~F}+10)^{-0.496}$ & 27.2 \\
\hline
\end{tabular}

\section{REGION 2}

$\mathrm{Q}_{2}=3.87(\mathrm{~A})^{0.905}(\mathrm{SL})^{0.260}(\mathrm{ST}+1)^{-0.160}(\mathrm{P}-20)^{0.976}(\mathrm{EL})^{-0.219}$

$25.4 \quad 2$

$\mathrm{Q}_{5}=7.09(\mathrm{~A})^{0.896}(\mathrm{SL})^{0.257}(\mathrm{ST}+1)^{-0.189}(\mathrm{P}-20)^{1.000}(\mathrm{EL})^{-0.255}$

$25.4 \quad 3$

$\mathrm{Q}_{10}=9.77(\mathrm{~A})^{0.891}(\mathrm{SL})^{0.251}(\mathrm{ST}+1)^{-0.209}(\mathrm{P}-20)^{1.019}(\mathrm{EL})^{-0.273}$

$25.5 \quad 5$

$\mathrm{Q}_{25}=13.5(\mathrm{~A})^{0.888}(\mathrm{SL})^{0.242}(\mathrm{ST}+1)^{-0.236}(\mathrm{P}-20)^{1.046}(\mathrm{EL})^{-0.291}$

$26.4 \quad 6$

$\mathrm{Q}_{50}=16.3(\mathrm{~A})^{0.887}(\mathrm{SL})^{0.236}(\mathrm{ST}+1)^{-0.256}(\mathrm{P}-20)^{1.066}(\mathrm{EL})^{-0.302}$

$27.3 \quad 8$

$\mathrm{Q}_{100}=19.1(\mathrm{~A})^{0.887}(\mathrm{SL})^{0.230}(\mathrm{ST}+1)^{-0.275}(\mathrm{P}-20)^{1.086}(\mathrm{EL})^{-0.311}$

28.6

$\mathrm{Q}_{500}=25.6(\mathrm{~A})^{0.889}(\mathrm{SL})^{0.218}(\mathrm{ST}+1)^{-0.318}(\mathrm{P}-20)^{1.134}(\mathrm{EL})^{-0.327}$

30.6

REGION 3

$\mathrm{Q}_{2}=45.6(\mathrm{~A})^{0.723}(\mathrm{ST}+1)^{-0.390}(\mathrm{P}-20)^{0.491}(\mathrm{SH})^{-0.273}$

$30.7 \quad 3$

$\mathrm{Q}_{5}=33.0(\mathrm{~A})^{0.718}(\mathrm{ST}+1)^{-0.405}(\mathrm{P}-20)^{0.806}(\mathrm{SH})^{-0.347}$

32.5

$\mathrm{Q}_{10}=29.2(\mathrm{~A})^{0.717}(\mathrm{ST}+1)^{-0.424}(\mathrm{P}-20)^{0.977}(\mathrm{SH})^{-0.401}$

34.6

8

$\mathrm{Q}_{25}=27.4(\mathrm{~A})^{0.717}(\mathrm{ST}+1)^{-0.452}(\mathrm{P}-20)^{1.155}(\mathrm{SH})^{-0.470}$

37.9

$\mathrm{Q}_{50}=27.5(\mathrm{~A})^{0.717}(\mathrm{ST}+1)^{-0.475}(\mathrm{P}-20)^{1.263}(\mathrm{SH})^{-0.521}$

40.6

$\mathrm{Q}_{100}=28.5(\mathrm{~A})^{0.718}(\mathrm{ST}+1)^{-0.499}(\mathrm{P}-20)^{1.354}(\mathrm{SH})^{-0.571}$

43.6

$\mathrm{Q}_{500}=33.1(\mathrm{~A})^{0.722}(\mathrm{ST}+1)^{-0.557}(\mathrm{P}-20)^{1.529}(\mathrm{SH})^{-0.682}$

50.9

\section{REGION 4}

$Q_{2}=14.1(\mathrm{~A})^{0.880}(\mathrm{ST}+1)^{-0.225}(\mathrm{P}-20)^{0.614}$
$\mathrm{Q}_{5}=17.2(\mathrm{~A})^{0.852}(\mathrm{ST}+1)^{-0.294}(\mathrm{P}-20)^{0.771}$
$\mathrm{Q}_{10}=19.6(\mathrm{~A})^{0.835}(\mathrm{ST}+1)^{-0.335}(\mathrm{P}-20)^{0.853}$
$\mathrm{Q}_{25}=22.3(\mathrm{~A})^{0.816}(\mathrm{ST}+1)^{-0.381}(\mathrm{P}-20)^{0.948}$
$\mathrm{Q}_{50}=24.0(\mathrm{~A})^{0.804}(\mathrm{ST}+1)^{-0.410}(\mathrm{P}-20)^{1.014}$
$\mathrm{Q}_{100}=25.3(\mathrm{~A})^{0.794}(\mathrm{ST}+1)^{-0.435}(\mathrm{P}-20)^{1.075}$
$\mathrm{Q}_{500}=27.5(\mathrm{~A})^{0.774}(\mathrm{ST}+1)^{-0.482}(\mathrm{P}-20)^{1.205}$ 
Table 2.--Full-regression equations for estimating peak discharges for streams in each of eight hydrologic regions of New York (continued).

[A = Drainage area, in square miles, $\mathrm{SL}=$ main channel slope, in feet per mile, $\mathrm{ST}=$ basin storage, in percent, $\mathrm{P}=$ mean annual precipitation, in inches, $\mathrm{F}=$ basin forested area, in percent, $\mathrm{EL}=$ average main stream channel elevation, in feet, and, $\mathrm{SH}=$ basin-shape index, in mile per mile. Region locations are shown on pl. 2]

\begin{tabular}{|c|c|c|}
\hline Regression equation & $\begin{array}{c}\text { Standard error of } \\
\text { prediction } \\
\text { (percent) }\end{array}$ & $\begin{array}{c}\text { Equivalent } \\
\text { years of record }\end{array}$ \\
\hline \multicolumn{3}{|l|}{ REGION 4A } \\
\hline$Q_{2}=2.09(A)^{0.904}(P-20)^{1.051}$ & 18.3 & 8 \\
\hline $\mathrm{Q}_{5}=2.18(\mathrm{~A})^{0.879}(\mathrm{P}-20)^{1.207}$ & 17.4 & 14 \\
\hline$Q_{10}=2.35(A)^{0.865}(\mathrm{P}-20)^{1.278}$ & 16.9 & 21 \\
\hline $\mathrm{Q}_{25}=2.55(\mathrm{~A})^{0.850}(\mathrm{P}-20)^{1.354}$ & 16.7 & 32 \\
\hline $\mathrm{Q}_{50}=2.64(\mathrm{~A})^{0.841}(\mathrm{P}-20)^{1.407}$ & 16.7 & 41 \\
\hline$Q_{100}=2.68(A)^{0.833}(\mathrm{P}-20)^{1.459}$ & 16.9 & 51 \\
\hline $\mathrm{Q}_{500}=2.62(\mathrm{~A})^{0.821}(\mathrm{P}-20)^{1.574}$ & 17.4 & 72 \\
\hline \multicolumn{3}{|l|}{ REGION 5} \\
\hline $\mathrm{Q}_{2}=20.3(\mathrm{~A})^{0.971}(\mathrm{SL})^{0.232}(\mathrm{ST}+1)^{-0.176}(\mathrm{SH})^{-0.093}$ & 29.3 & 2 \\
\hline $\mathrm{Q}_{5}=26.4(\mathrm{~A})^{0.979}(\mathrm{SL})^{0.272}(\mathrm{ST}+1)^{-0.189}(\mathrm{SH})^{-0.130}$ & 27.2 & 4 \\
\hline $\mathrm{Q}_{10}=30.2(\mathrm{~A})^{0.981}(\mathrm{SL})^{0.295}(\mathrm{ST}+1)^{-0.196}(\mathrm{SH})^{-0.141}$ & 26.5 & 6 \\
\hline $\mathrm{Q}_{25}=35.2(\mathrm{~A})^{0.980}(\mathrm{SL})^{0.316}(\mathrm{ST}+1)^{-0.204}(\mathrm{SH})^{-0.147}$ & 26.2 & 8 \\
\hline $\mathrm{Q}_{50}=39.2(\mathrm{~A})^{0.978}(\mathrm{SL})^{0.329}(\mathrm{ST}+1)^{-0.211}(\mathrm{SH})^{-0.150}$ & 26.4 & 10 \\
\hline $\mathrm{Q}_{100}=43.4(\mathrm{~A})^{0.976}(\mathrm{SL})^{0.339}(\mathrm{ST}+1)^{-0.217}(\mathrm{SH})^{-0.152}$ & 26.9 & 12 \\
\hline $\mathrm{Q}_{500}=53.5(\mathrm{~A})^{0.972}(\mathrm{SL})^{0.357}(\mathrm{ST}+1)^{-0.231}(\mathrm{SH})^{-0.158}$ & 29.0 & 14 \\
\hline \multicolumn{3}{|l|}{ REGION 6} \\
\hline $\mathrm{Q}_{2}=8.80(\mathrm{~A})^{0.870}(\mathrm{SL})^{0.233}(\mathrm{ST}+1)^{-0.217}(\mathrm{P}-20)^{0.481}$ & 38.3 & 2 \\
\hline $\mathrm{Q}_{5}=13.3(\mathrm{~A})^{0.869}(\mathrm{SL})^{0.302}(\mathrm{ST}+1)^{-0.216}(\mathrm{P}-20)^{0.408}$ & 33.6 & 3 \\
\hline $\mathrm{Q}_{10}=16.2(\mathrm{~A})^{0.869}(\mathrm{SL})^{0.334}(\mathrm{ST}+1)^{-0.217}(\mathrm{P}-20)^{0.379}$ & 32.4 & 5 \\
\hline $\mathrm{Q}_{25}=19.7(\mathrm{~A})^{0.869}(\mathrm{SL})^{0.360}(\mathrm{ST}+1)^{-0.220}(\mathrm{P}-20)^{0.360}$ & 32.8 & 7 \\
\hline $\mathrm{Q}_{50}=22.1(\mathrm{~A})^{0.869}(\mathrm{SL})^{0.374}(\mathrm{ST}+1)^{-0.224}(\mathrm{P}-20)^{0.356}$ & 34.1 & 9 \\
\hline $\mathrm{Q}_{100}=24.1(\mathrm{~A})^{0.870}(\mathrm{SL})^{0.385}(\mathrm{ST}+1)^{-0.228}(\mathrm{P}-20)^{0.359}$ & 36.0 & 9 \\
\hline $\mathrm{Q}_{500}=27.5(\mathrm{~A})^{0.872}(\mathrm{SL})^{0.406}(\mathrm{ST}+1)^{-0.244}(\mathrm{P}-20)^{0.380}$ & 42.1 & 10 \\
\hline \multicolumn{3}{|l|}{ REGION 7} \\
\hline $\mathrm{Q}_{2}=92.3(\mathrm{~A})^{0.998}(\mathrm{SL})^{0.460}(\mathrm{ST}+1)^{-0.311}(\mathrm{P}-20)^{0.737}(\mathrm{EL})^{-0.755}(\mathrm{SH})^{0.243}$ & 30.4 & 2 \\
\hline $\mathrm{Q}_{5}=98.7(\mathrm{~A})^{1.005}(\mathrm{SL})^{0.509}(\mathrm{ST}+1)^{-0.311}(\mathrm{P}-20)^{0.829}(\mathrm{EL})^{-0.784}(\mathrm{SH})^{0.267}$ & 28.4 & 3 \\
\hline$Q_{10}=94.5(\mathrm{~A})^{1.009}(\mathrm{SL})^{0.528}(\mathrm{ST}+1)^{-0.312}(\mathrm{P}-20)^{0.892}(\mathrm{EL})^{-0.788}(\mathrm{SH})^{0.275}$ & 28.1 & 4 \\
\hline $\mathrm{Q}_{25}=83.7(\mathrm{~A})^{1.014}(\mathrm{SL})^{0.543}(\mathrm{ST}+1)^{-0.312}(\mathrm{P}-20)^{0.964}(\mathrm{EL})^{-0.781}(\mathrm{SH})^{0.281}$ & 28.9 & 5 \\
\hline $\mathrm{Q}_{50}=74.5(\mathrm{~A})^{1.019}(\mathrm{SL})^{0.550}(\mathrm{ST}+1)^{-0.313}(\mathrm{P}-20)^{1.011}(\mathrm{EL})^{-0.770}(\mathrm{SH})^{0.282}$ & 30.0 & 6 \\
\hline $\mathrm{Q}_{100}=65.6(\mathrm{~A})^{1.024}(\mathrm{SL})^{0.555}(\mathrm{ST}+1)^{-0.313}(\mathrm{P}-20)^{1.054}(\mathrm{EL})^{-0.758}(\mathrm{SH})^{0.283}$ & 31.6 & 7 \\
\hline $\mathrm{Q}_{500}=48.4(\mathrm{~A})^{1.038}(\mathrm{SL})^{0.568}(\mathrm{ST}+1)^{-0.313}(\mathrm{P}-20)^{1.148}(\mathrm{EL})^{-0.730}(\mathrm{SH})^{0.281}$ & 36.2 & 7 \\
\hline
\end{tabular}


Table 3.--Summary of full-regression equations (table 2) for estimating peak discharges in New York, based on information from GLS regression models for estimating 2, 5, 10, 25, 50, 100, and 500-year peak discharges.

[Locations of hydrologic regions are shown on pl. 2]

\begin{tabular}{|c|c|c|c|c|}
\hline $\begin{array}{l}\text { Hydrologic } \\
\text { region }\end{array}$ & Explanatory variables ${ }^{1}$ & $\begin{array}{l}\text { Standard error of } \\
\text { the estimate } \\
\text { (percent) }\end{array}$ & $\begin{array}{c}\text { Estimated } \\
\text { standard error of } \\
\text { prediction } \\
\text { (percent) }\end{array}$ & $\begin{array}{c}\text { Number of } \\
\text { gaging stations }\end{array}$ \\
\hline 1 & $A,(S T+5),(P-20),(F+10)$ & $18-22$ & $21-27$ & 31 \\
\hline 2 & A, SL, $(\mathrm{ST}+1),(\mathrm{P}-20), \mathrm{EL}$ & $23-27$ & $25-31$ & 49 \\
\hline 3 & $\mathrm{~A},(\mathrm{ST}+1),(\mathrm{P}-20), \mathrm{SH}$ & $28-43$ & $31-51$ & 42 \\
\hline 4 & $A,(S T+1),(P-20)$ & $20-25$ & $24-34$ & 23 \\
\hline $4 \mathrm{~A}$ & A, (P-20) & $10-16$ & $17-18$ & 17 \\
\hline 5 & $\mathrm{~A}, \mathrm{SL},(\mathrm{ST}+1), \mathrm{SH}$ & $24-27$ & $26-29$ & 48 \\
\hline 6 & A, SL $(\mathrm{ST}+1),(\mathrm{P}-20)$ & $30-39$ & $32-42$ & 73 \\
\hline 7 & $\mathrm{~A}, \mathrm{SL},(\mathrm{ST}+1),(\mathrm{P}-20), \mathrm{EL}, \mathrm{SH}$ & $24-30$ & $28-36$ & 30 \\
\hline
\end{tabular}

$1 \quad A=$ drainage area of the basin, in square miles.

SL = main-channel slope, in feet per mile.

$\mathrm{ST}=$ basin storage, in percent of total basin drainage area.

$\mathbf{P}=$ mean annual precipitation, in inches.

$F=$ basin forest cover, in percent of total basin drainage area.

$\mathrm{EL}=$ average main-channel elevation, in feet.

$\mathrm{SH}=$ basin shape index, in mile per mile.

Several of these variables require a constant value to be added or subtracted before discharge computation (for example, for each equation with mean annual precipitation (P) included as a significant explanatory variable, a constant of 20 should be subtracted from the plate 1 value of $P$ before computations).

Table 4.---Correction factors to adjust regional full-regression equations for transformation bias.

[Full-regression equations are given in table 2. Locations of hydrologe regions are shown in pl. 2.].

\begin{tabular}{ccccccccc}
\hline $\begin{array}{c}\text { Recurrence } \\
\text { interval }\end{array}$ & \multicolumn{7}{c}{ Hydrologic Region } \\
\cline { 2 - 10 } (years) & $\mathbf{1}$ & $\mathbf{2}$ & $\mathbf{3}$ & $\mathbf{4}$ & $\mathbf{4 A}$ & $\mathbf{5}$ & 6 & 7 \\
\hline 2 & 1.017 & 1.027 & 1.038 & 1.026 & 1.012 & 1.037 & 1.064 & 1.034 \\
5 & 1.016 & 1.027 & 1.041 & 1.020 & 1.010 & 1.031 & 1.049 & 1.029 \\
10 & 1.016 & 1.027 & 1.045 & 1.019 & 1.009 & 1.029 & 1.045 & 1.028 \\
25 & 1.017 & 1.028 & 1.052 & 1.020 & 1.008 & 1.028 & 1.046 & 1.029 \\
50 & 1.019 & 1.030 & 1.059 & 1.021 & 1.007 & 1.028 & 1.049 & 1.031 \\
100 & 1.021 & 1.032 & 1.067 & 1.024 & 1.006 & 1.028 & 1.054 & 1.033 \\
500 & 1.024 & 1.036 & 1.088 & 1.032 & 1.005 & 1.032 & 1.073 & 1.043 \\
\hline
\end{tabular}




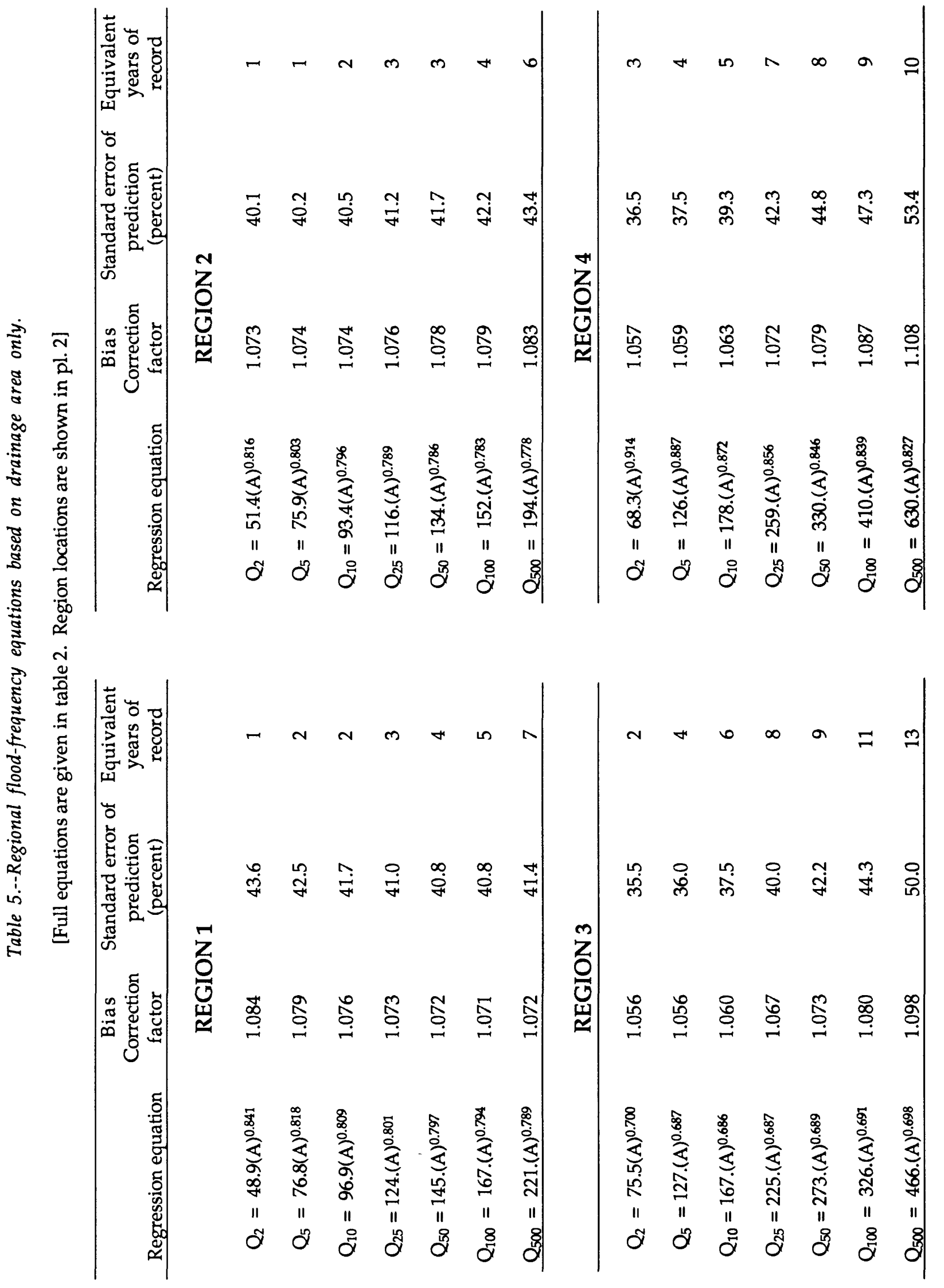




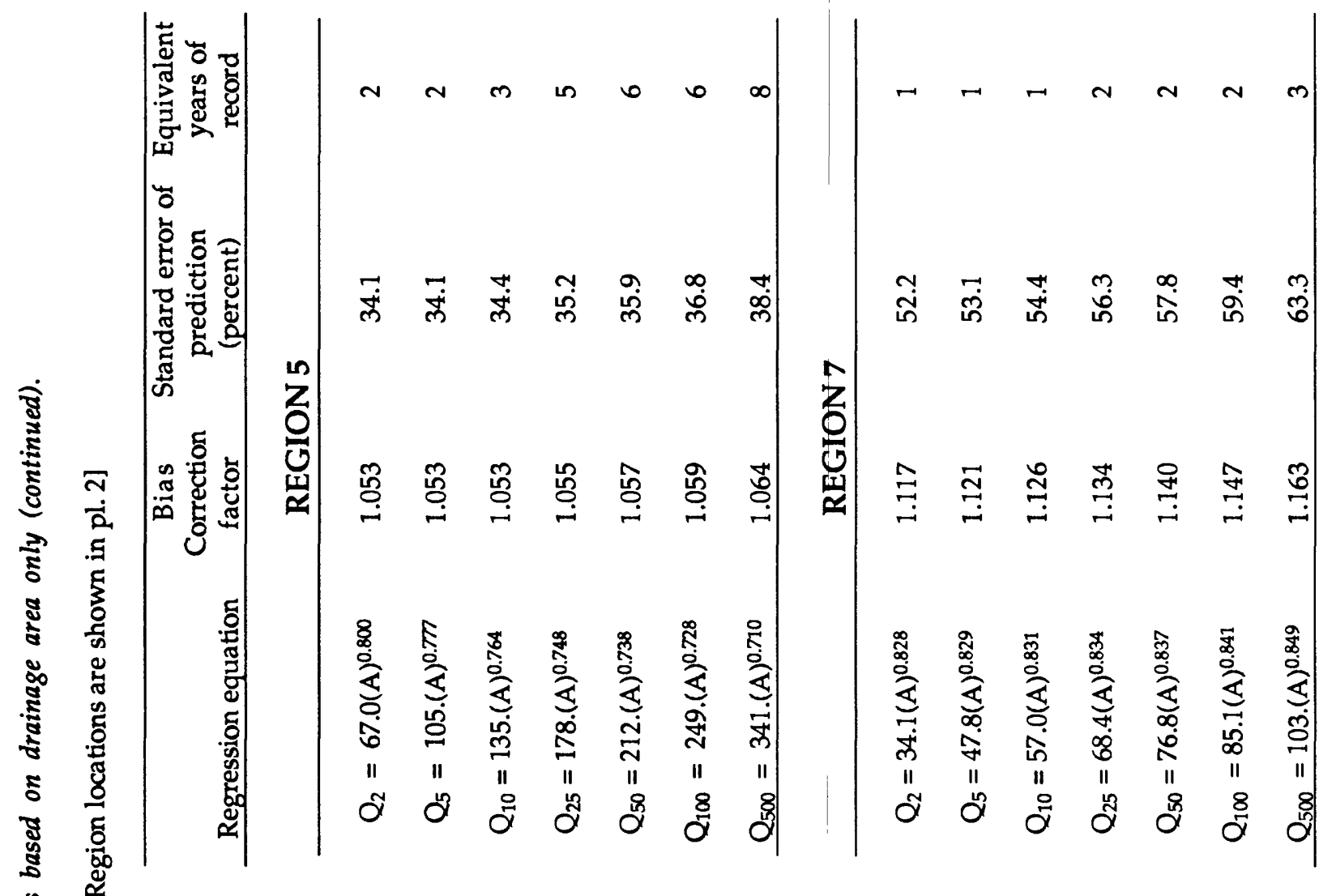

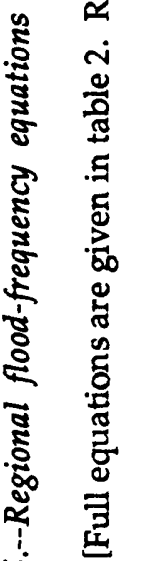

क्ष

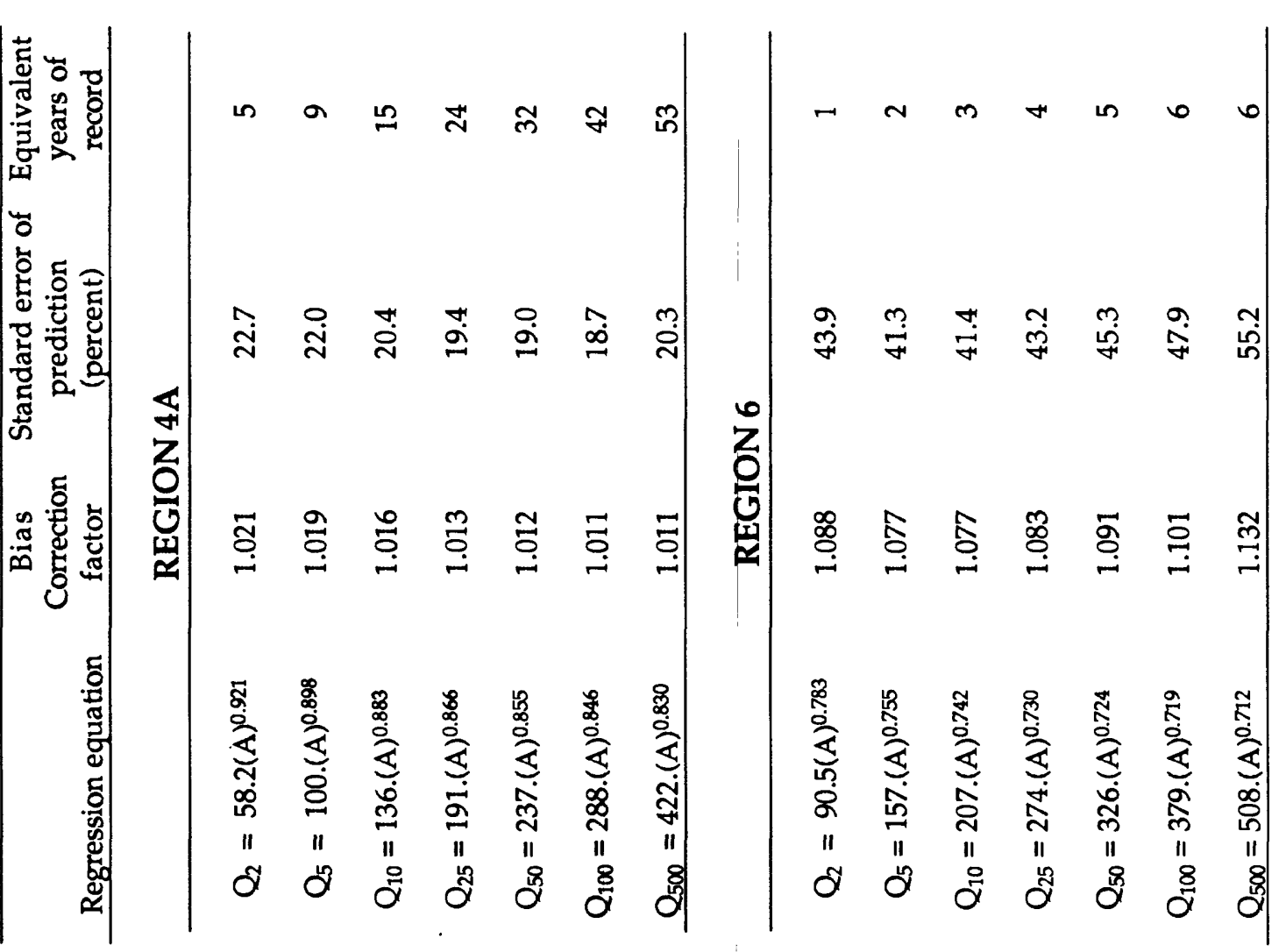



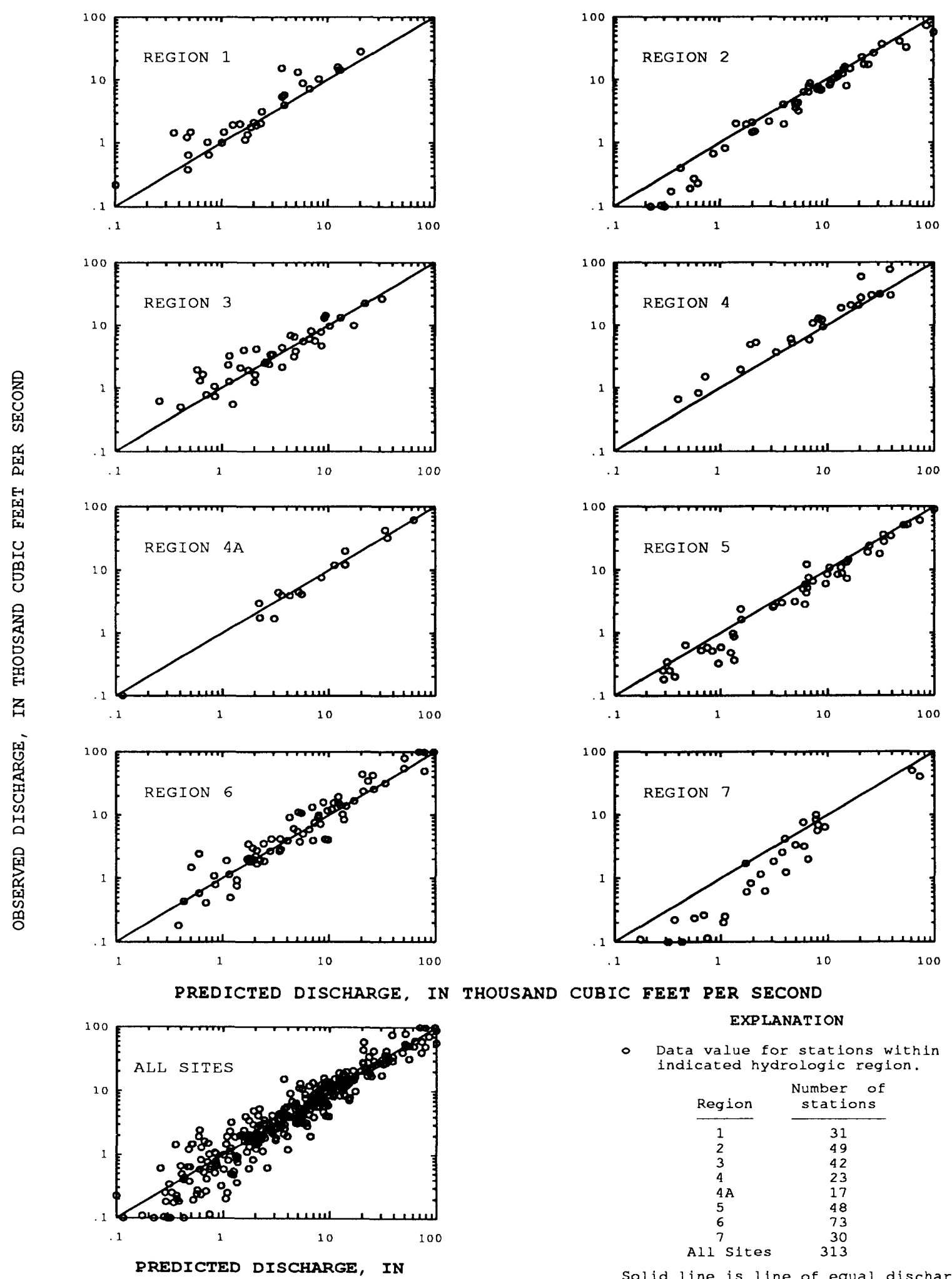

EXPIANATION

- Data value for stations within indicated hydrologic region.

THOUSAND CUBIC FEET PER SECOND

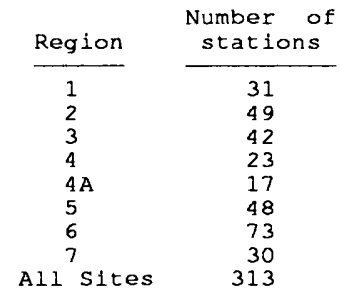

Solid line is line of equal discharge.

Figure 13A.--Observed 50-year discharges and 50-year discharges predicted from equations of Zembrzuski and Dunn (1979) for stations within the eight hydrologic regions of New York. (Locations of regions are shown on pl. 2.) 

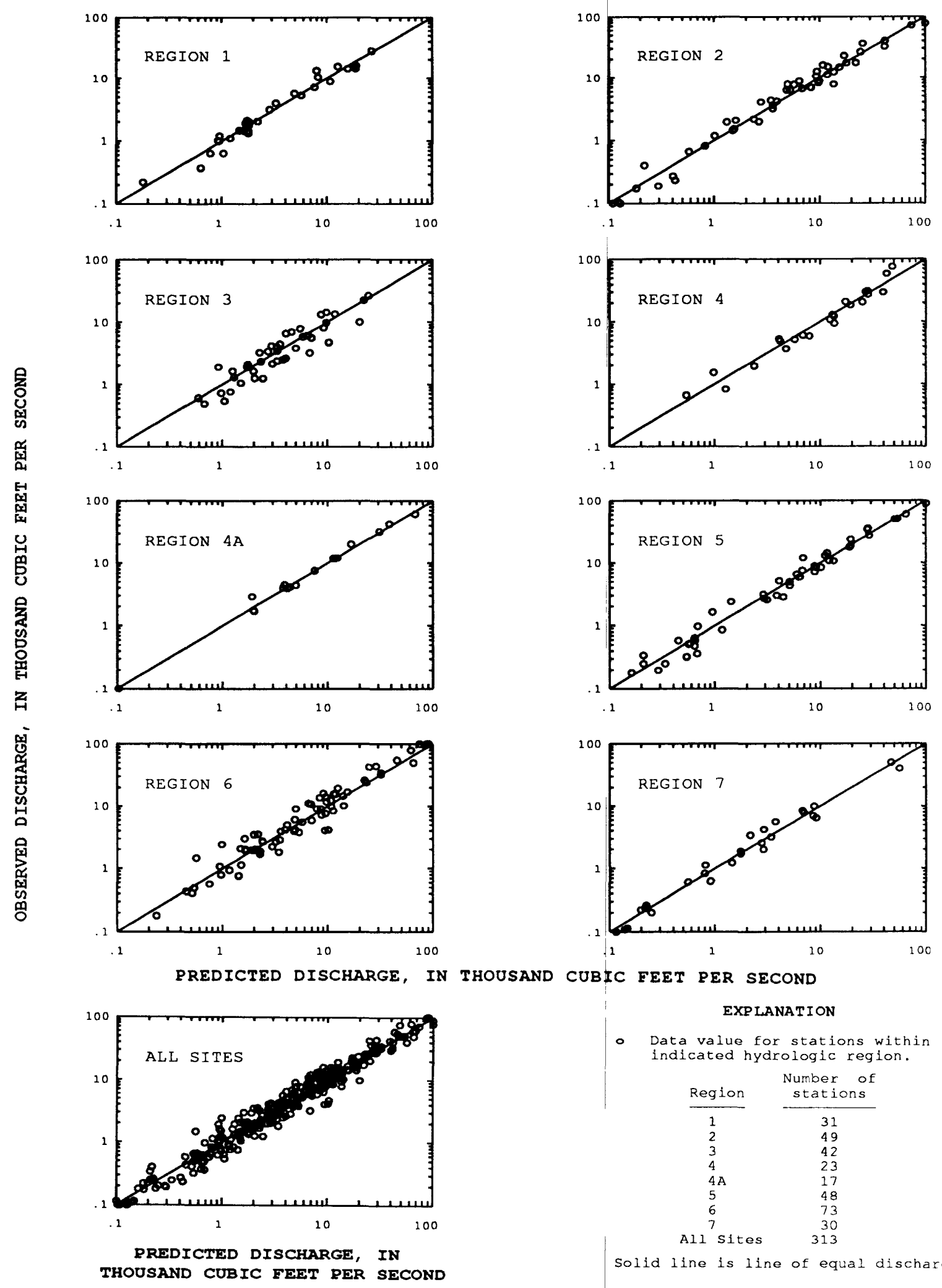

Solid line is line of equal discharge.

Figure 13B.--Observed 50-year discharges and 50-year discharges predicted from GLS (generalized least squares) full regression equations for stations within the eight hydrologic regions of New York. (Locations of regions are shown on pl. 2.) 

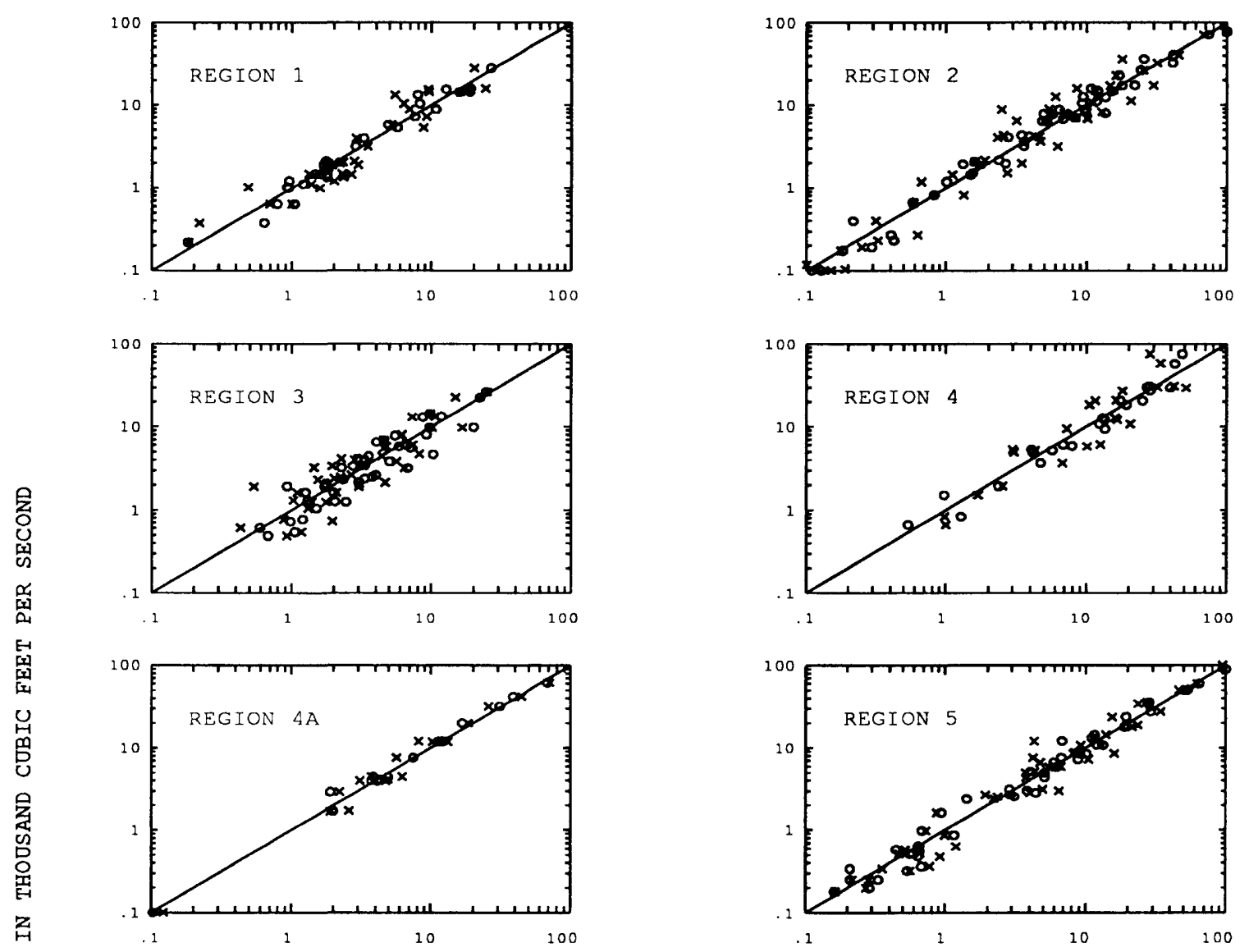

뭉
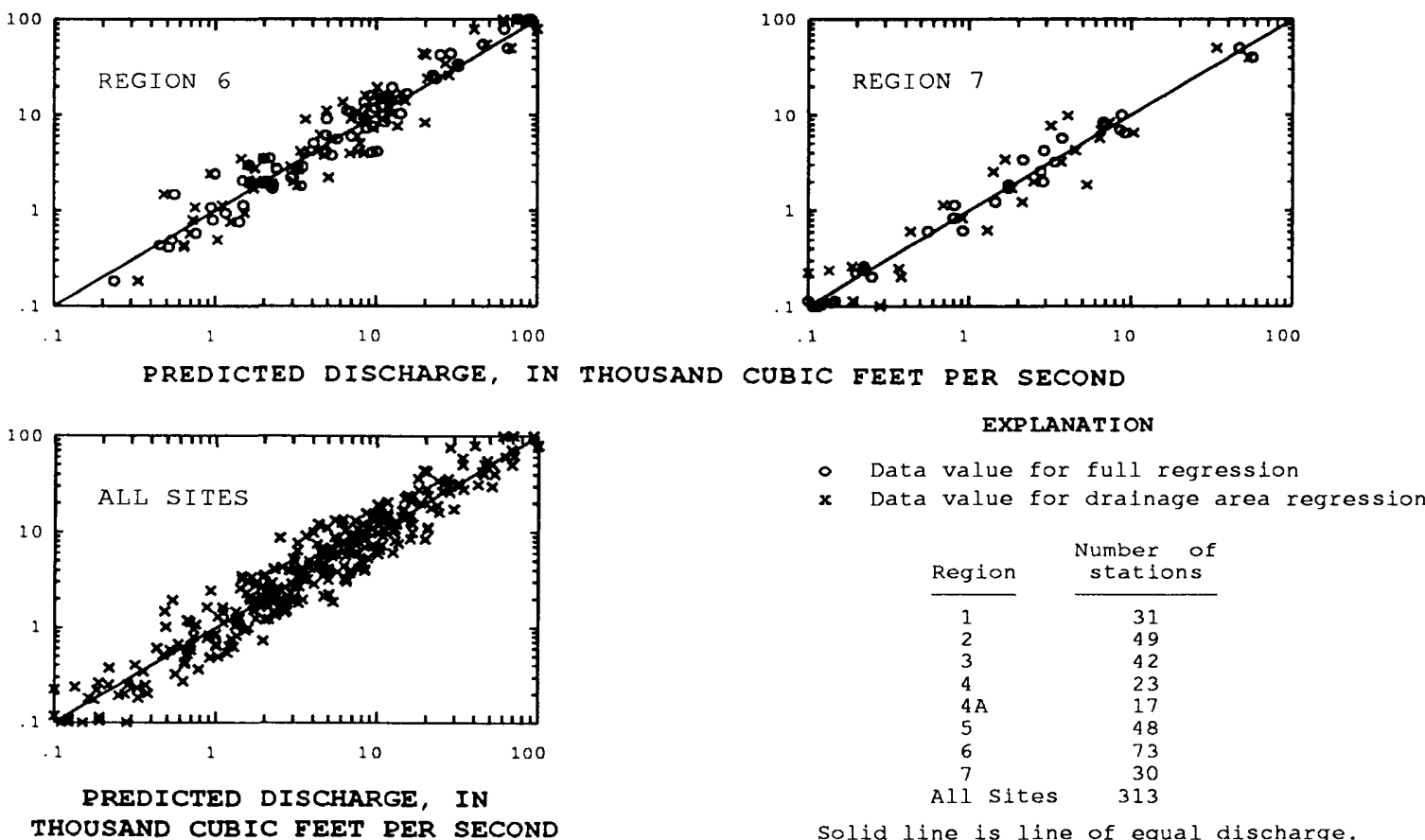

Figure 13C.--Observed 50-year discharges and 50-year discharges predicted from full- and drainagearea-only GLS (generalized least squares) regression equations for stations within the eight hydrologic regions of New York. (Locations of regions are shown on pl. 2.) 


\section{COMPUTATION OF PEAK DISCHARGE}

Methods for computing a peak discharge for a selected recurrence interval at a specific site depend on whether the site is gaged or ungaged and whether the drainage area crosses hydrologic-region boundaries or State lines. Methods for gaged and ungaged sites are given below with examples of each technique.

\section{Gaged Sites}

The GLS regional-regression equations can be used to improve gaging-station estimates (based on flood-frequency analysis of the gaged record) by using a weighted average of the two estimates (regression and gaged). Incorporating the regression estimate into the weighted average tends to decrease time sampling errors that result for sites with short periods of record. The station number, peak-discharge statistics, and gaged, regression, and weighted flood-frequency values for gaging stations used in the study are given in table 9 (at end of report). The weighted discharges generally give the best estimate.

The weighted average discharge is computed from the equation,

$$
Q_{T(w)}=\frac{Q_{T(g)}(N)+Q_{T(t)}(E)}{N+E}
$$

where:

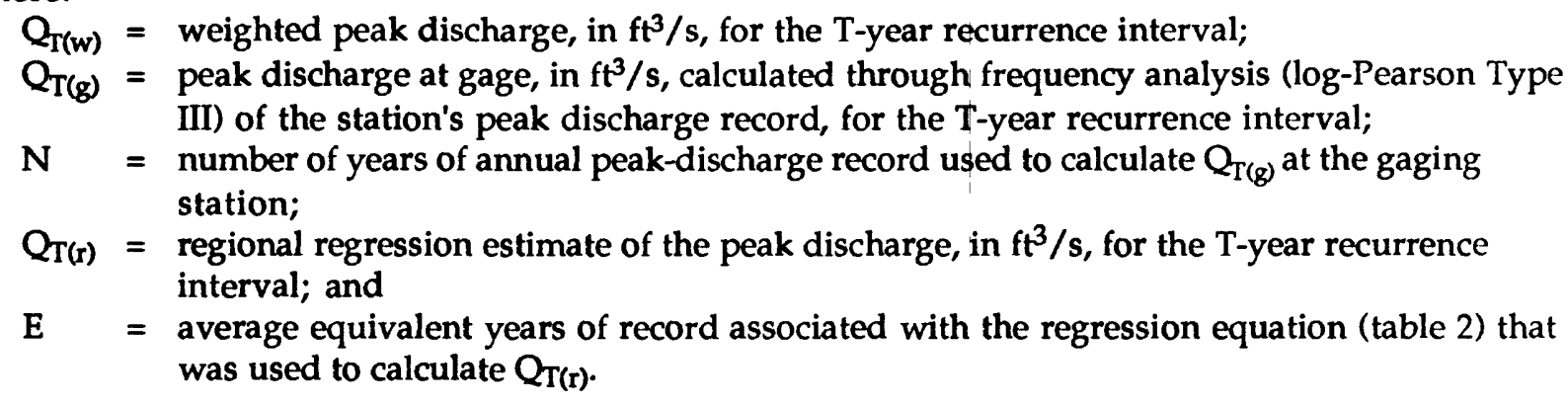

\section{Ungaged Sites}

The following methods may be used to estimate peak discharges of selected recurrence intervals for sites on ungaged streams, depending on whether (1) the drainage area is within a single hydrologic region, (2) the drainage area crosses a hydrologic-region boundary or State boundary, or (3) the ungaged site is near a gaged site on the same stream. Procedures for each of these conditions are described below:

(1) If the drainage area of an ungaged site lies entirely within a single hydrologic region (pl. 2), peak discharges for selected recurrence intervals are computed from the regression equations (table 2 ) for that region.

(2) If the drainage area of an ungaged site crosses a hydrologic-region boundary or State boundary, the percentage of drainage within each region and(or) State is determined. Peak-discharge estimates are computed for the entire drainage basin through each of the appropriate regional or State equations, and the drainage-area percentages are used as weighting factors by multiplying the percentages by the corresponding peak-discharge estimate; the resulting values are then summed to compute the peak discharge for the entire basin. Out-of-state equations are given in U.S.

Geological Survey or State flood-frequency reports for New Jersey (Stankowski, 1974 with update by $R$. Schopp in progress), Pennsylvania (Flippo, 1977), Connecticut (Weiss, 1983), Massachusetts (Wandle, 1983), and Vermont (Johnson and Tasker, 1974).

(3) If the ungaged site for which flood-frequency estimates are needed is on a gaged stream, and if the site's drainage area is between 50 and 150 percent of the drainage area of the stream at the gage, the following procedure (Choquette, 1988) is suggested: 
(a) Estimate the peak discharge $\left(Q_{T(w)}\right)$ at the gaged site by the procedure given in the preceding section, "Gaged Sites."

(b) Compute the following ratio for the gaged site, as follows:

where:

$$
\mathrm{C}_{\mathrm{g}}=\mathrm{Q}_{\mathrm{T}(\mathrm{w})} / \mathrm{Q}_{\mathrm{T}(\mathrm{r})}
$$

$\mathrm{C}_{\mathrm{g}}=$ correction-factor ratio for the gaged site,

$\mathrm{Q}_{\mathrm{T}(w)}=$ weighted peak-discharge estimate for the gaged site; and

$\mathrm{Q}_{\mathrm{T}(\mathrm{r})}=$ regression peak-discharge estimate for the gaged site.

(c) Compute the following ratio for the ungaged site:

where:

$$
C_{u}=C_{g}-\left[2\left(\left|A_{g}-A_{u}\right|\right) / A_{g}\left(C_{g}-1\right)\right.
$$

$\mathrm{C}_{\mathrm{u}}=$ correction factor ratio for the ungaged site,

$\mathrm{C}_{\mathrm{g}}=$ correction factor ratio for the gaged site,

$A_{g}=$ drainage area of the gaged site,

$A_{u}=$ drainage area of the ungaged site (must be within 50 and 150 percent of the drainage area at the gaged site), and

$\left|A_{g}-A_{u}\right|=$ absolute value of the difference between drainage areas for the gaged and ungaged sites.

(d) Compute the weighted peak-discharge estimate at the ungaged site, as follows:

where:

$$
\mathrm{Q}_{\mathrm{T}(w)}=\mathrm{C}_{\mathrm{u}}\left(\mathrm{Q}_{\mathrm{T}(\mathrm{r})}\right) \text {, }
$$

$\mathrm{Q}_{\mathrm{T}(w)}=$ weighted peak-discharge estimate for the ungaged site,

$\mathrm{C}_{\mathrm{u}}=$ correction factor ratio for the ungaged site, and

$\mathrm{Q}_{\mathrm{T}(\mathrm{r})}=$ regression peak-discharge estimate for the ungaged site.

As the difference in drainage area between the gaged site and the ungaged site approaches either 50 or 150 percent of the drainage area at the gaged site, the value of $C_{u}$ approaches 1 , in which case the adjustment has no effect on the regression estimate for the ungaged site.

\section{Sample Computations}

The following examples illustrate use of the methods described previously.

Example 1. Gaged site with drainage area within a single hydrologic region: Estimate the 50-year peak discharge at the gage site on Canaseraga Creek near Dansville (04225000).

Given: a) Gaged basin is in hydrologic region 6 (pl. 2)

b) Drainage area $=152.0 \mathrm{mi}^{2}$ (table 10)

c) Main channel slope $=33.50 \mathrm{ft} / \mathrm{mi}$ (table 10)

d) Area (in percent of total drainage area) of lakes, ponds, and swamps (basin storage) = 0.84 percent (table 10$)$

e) Mean annual precipitation $=33.0 \mathrm{in}$. (pl. 1 and table 10)

f) The 50-year peak-discharge $\left(Q_{50(g)}\right)$ based on the gaged record $=10,300 \mathrm{ft}^{3} / \mathrm{s}$ (table 9)

g) Number of years $(\mathrm{N})$ of annual peak-discharge record used to determine $Q_{50(g)}=61$ years (table 9) 


\section{Solution:}

The regression estimate $\left(Q_{50(x)}\right)$ for station 04225000 is computed by the following equation for region 6 (table 2):

$$
\mathrm{Q}_{50(x)}=22.1(\mathrm{~A})^{0.869}(\mathrm{SL})^{0.374}(\mathrm{ST}+1)^{-0.224}(\mathrm{P}-20)^{0.356}
$$

From the given basin characteristics:

$$
\begin{aligned}
& Q_{50(x)}=22.1(152)^{0.869}(33.5)^{0.374}(0.84+1)^{-0.224}(33.0-20)^{0.356} \\
& \left.Q_{50(x)}=14,100 \mathrm{ft}^{3} / \mathrm{s} \text { (also in table } 9\right)
\end{aligned}
$$

The equivalent years of record (E) for $Q_{50(r)}$ for region 6 is 9 years (table 2). Therefore, the weighted peak-discharge $Q_{50(w)}$ for station 04225000 (method for gaged sites) is:

$$
\begin{aligned}
& Q_{50(W)}=\frac{Q_{50(g)}(N)+Q_{50(r)}(E)}{N+E} \\
& Q_{50(W)}=\frac{(10,300)(61)+(14,100)(9)}{61+9} \\
& Q_{50(w)}=10,800 \mathrm{ft}^{3} / \mathrm{s}
\end{aligned}
$$

Example 2. Drainage area crosses hydrologic region boundaries: Compute the 50-year peak-discharge regression estimate for Genesee River at Rochester (04232000). For this example, assume this site is ungaged.

Given: a) Drainage area at the site is $2,467 \mathrm{mi}^{2}$, and the site is in hydrologic region 7 (pl. 2)

b) The upper 53.5 percent $\left(1,321 \mathrm{mi}^{2}\right)$ of the basin is in hydrologic region 6 .

c) Main channel slope $=8.13 \mathrm{ft} / \mathrm{mi}$ (table 10).

d) Area of lakes, ponds, and swamps $=3.17$ percent (table 10)

e) Mean annual precipitation $=33.5 \mathrm{in}$ (pl. 1 and table 10)

f) Average channel elevation $=1,006 \mathrm{ft}$ (table 10)

g) Stream length $=158.5 \mathrm{mi}$ (table 10)

\section{Solution:}

Percentage of total drainage area within hydrologic region 6 is 53.5 percent, and Percentage of total drainage area within hydrologic region 7 is 46.5 percent.

These are the weighting factors after computing 50-year peak-discharges at the gaged site through regression equations for regions 6 and 7.

$\mathrm{Q}_{50(\mathrm{r})}\left(\right.$ region 6) $=22.1(\mathrm{~A})^{0.869}(\mathrm{SL})^{0.374}(\mathrm{ST}+1)^{-0.224}(\mathrm{P}-20)^{0.356}($ table 2$)$

$\mathrm{Q}_{50(\mathrm{r})}$ (region 6) $=22.1(2,467)^{0.869}(8.13)^{0.374}(3.17+1)^{-0.224}(33.5-20)^{0.356}$

$\mathrm{Q}_{50(\mathrm{r})}($ region 6$)=78,700 \mathrm{ft}^{3} / \mathrm{s}$

The basin-shape index (SH) is computed as the stream length squared, divided by the drainage area.

$$
\begin{aligned}
\mathrm{SH} & =\frac{(158.5)^{2}}{2,467} \\
\mathrm{SH} & =10.18 \text { (also in table } 10)
\end{aligned}
$$

$\mathrm{Q}_{50(\mathrm{r})}($ region 7$)=74.5(\mathrm{~A})^{1.019}(\mathrm{SL})^{0.550}(\mathrm{ST}+1)^{-0.313}(\mathrm{P}-20)^{1.011}(\mathrm{EL})^{-0.770}(\mathrm{SH})^{0.282}($ table 2$)$

$\mathrm{Q}_{50(\mathrm{r})}$ (region 7$)=74.5(2,467)^{1.019}(8.13)^{0.550}(3.17+1)^{-0.313}(33.5-20)^{1.011}(1,006)^{-0.770}(10.18)^{0.282}$

$\mathrm{Q}_{50(\mathrm{r})}($ region 7$)=56,300 \mathrm{ft}^{3} / \mathrm{s}$ 
Use drainage-area percentages as weighting factors to compute final 50-year regression estimate at station 04232000:

$$
\mathrm{Q}_{50(\mathrm{r})}=\underset{(78,700)(0.535)}{(} \stackrel{(56,300)}{/ /}(0.465)=68,300 \mathrm{ft}^{3} / \mathrm{s} \text { (also in table 9) }
$$

Note that the Genesee River at Rochester is currently regulated, and the above information represents preregulation conditions. The example is for illustration purposes only and is not applicable to present conditions at this station.

Example 3. Ungaged site near a gaged site on the same stream: Estimate the 50-year peak-discharge at the ungaged site Canaseraga Creek at Groveland.

Given a) This site's basin is in hydrologic region 6 downstream from the gaged site of Canaseraga Creek near Dansville (station 04225000, drainage area $=152 \mathrm{mi}^{2}$ ).

b) Drainage area at Groveland $=180 \mathrm{mi}^{2}$ (from 7.5-minute topographic maps)

c) Main channel slope $=29.0 \mathrm{ft} / \mathrm{mi}$ (from 7.5 -minute topographic maps)

d) Area of lakes, ponds and swamps $=0.97$ percent of basin (from 7.5-minute topographic maps)

e) Mean annual precipitation $=32.0 \mathrm{in}$. (pl. 1)

\section{Solution:}

The drainage area of Canaseraga Creek at Groveland is between 50 and 150 percent of the drainage area at the gage near Dansville; use the method for an ungaged site near a gaged site on the same stream.

The correction factor ratio for the gaged site near Dansville (04225000) is:

$$
\begin{aligned}
& C_{g}=Q_{50(w)} / Q_{50}(r) \\
& C_{g}=10,800 / 14,100 \text { (data from example } 1 \text { and table 9) } \\
& C_{g}=0.766
\end{aligned}
$$

The correction factor ratio for the ungaged site at Groveland is

$$
\begin{aligned}
& C_{u}=C_{g}-\left[2\left(\mid A_{g}-A_{d} \downarrow\right) / A_{g}\right]\left(C_{g}-1\right) \\
& C_{u}=0.766-[2(|152-180|) / 152](0.766-1) \\
& C_{u}=0.852
\end{aligned}
$$

From the given basin characteristics, the 50 -year regression estimate $\left(\mathrm{Q}_{50}(\mathrm{r})\right.$ ) for the ungaged site at Groveland is computed from the following equation for region 6 (table 2):

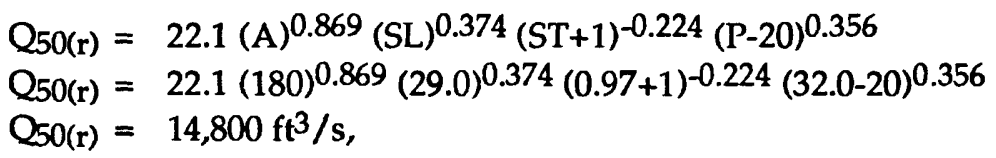

The weighted 50-year peak-discharge estimate at the ungaged site at Groveland is:

$$
\begin{aligned}
& Q_{50}(w)=C u\left(Q_{50}(r)\right. \\
& Q_{50}(w)=0.852(14,800) \\
& Q_{50(w)}=12,600 \mathrm{ft}^{3} / \mathrm{s} .
\end{aligned}
$$




\section{LIMITATIONS, ACCURACY, AND SENSITIVITY OF REGRESSION EQUATIONS}

The regression equations developed in this study apply to streams in New York where peak discharge is not significantly affected by stream regulation (no more than 20 percent of the drainage area is upstream from a controlled reservoir), or by diversion or other manmade influences. The equations are not applicable to basins in urban areas (where more than 15 percent of the basin is urbanized) unless the effects of urbanization on high flow are insignificant. Channelization, channel structures or constrictions, and significant withdrawals from the stream may alter peak discharges and cause them to differ from those expected under natural conditions. If the effects of urbanization can be quantified, adjustments to the "rural" peak-discharge estimates can be made through procedures outlined by Sauer and others (1983) to estimate peak discharge for urban areas. Lumia (1984) developed peak-discharge profiles for several streams in Rockland County, including many urbanized basins.

The relation between peak discharge and basin characteristics (actually the logarithms of these variables) given by the multiple linear regression equation is assumed to be linear only within the range of characteristics that define that relation. The suitability of the regional equations is undefined for streams having values beyond the ranges used, and extrapolation requires extreme caution or may be infeasible. The range of each basin characteristic for each region is given in table 6 .

In flood-frequency analyses, the gaged record is assumed to be representative of long-term conditions; sampling error results from limitations on the number of years of gaged record available and from hydrologic conditions during the particular period sampled. The use of generalized least-squares regression minimizes but does not prevent this type of error.

The standard error of estimate and estimated prediction error are indices of the expected accuracy of the regression estimates. If all assumptions for applying regression are met, the discrepancy between the regression estimate and actual streamflow will be within one standard error about 68 percent of the time.

The basin characteristics used in the estimating equations must be computed or estimated from maps or other sources of data and therefore are subject to error in measurement and judgment. To determine how much variability is introduced by error in computing the basin characteristics, sensitivity tests were conducted on the 50-year peak-discharge regression equation for each hydrologic region; results (table 7) should be indicative of the relative magnitude of the sensitivities of the remaining equations. The data presented in table 7 were computed by varying only one basin characteristic at a time while holding all others in that equation constant. Each characteristic was increased 10, 20, and 30 percent, then decreased 10,20, and 30 percent; the resulting changes in computed peak discharge are given in

Table 6.--Range in regional basin characteristics used in the regression analyses for eight hydrologic regions in New York.

[Hydrologic region locations are shown in pl. 2.]

\begin{tabular}{|c|c|c|c|c|c|c|c|}
\hline \multirow[b]{2}{*}{$\begin{array}{l}\text { Hydrologic } \\
\text { region }\end{array}$} & \multicolumn{7}{|c|}{ Basin characteristics } \\
\hline & $\begin{array}{c}\text { Area (A) } \\
\text { (square } \\
\text { miles) }\end{array}$ & $\begin{array}{c}\text { Slope (SL) } \\
\text { (feet per } \\
\text { mile) }\end{array}$ & $\begin{array}{c}\text { Storage (ST) } \\
\text { (percent) }\end{array}$ & $\begin{array}{c}\text { Precipita- } \\
\text { tion (P) } \\
\text { (inches) }\end{array}$ & $\begin{array}{l}\text { Elevation } \\
\text { (EL) } \\
\text { (feet) }\end{array}$ & $\begin{array}{l}\text { Forest area } \\
\text { (F) (percent) }\end{array}$ & $\begin{array}{l}\text { Shape index } \\
\text { (SH) (mile } \\
\text { per mile) }\end{array}$ \\
\hline 1 & $1.34-612$ & $3.60-204$ & $0.01-31.6$ & $32.0-55.0$ & $304-1,780$ & $11.0-95.0$ & $2.27-14.7$ \\
\hline 2 & $.54-4,500$ & $9.20-252$ & $.01-12.2$ & $32.0-55.5$ & $205-2,209$ & $20.0-99.0$ & $1.09-17.8$ \\
\hline 3 & $1.93-711$ & $5.00-248$ & $.94-11.2$ & $37.0-47.0$ & $56-1,200$ & $19.0-99.0$ & $1.31-9.77$ \\
\hline 4 & $3.61-386$ & $21.8-316$ & $.01-7.42$ & $36.0-57.5$ & $485-2,340$ & $21.0-98.0$ & $1.29-11.2$ \\
\hline $4 \mathrm{~A}$ & $.41-784$ & $9.30-435$ & $.01-\quad 5.87$ & $40.5-54.0$ & $1,005-2,180$ & $38.0-100$ & $1.98-6.48$ \\
\hline 5 & $.70-3,941$ & $3.00-326$ & $.01-120$ & $39.0-43.5$ & $553-1,810$ & $14.0-100$ & $1.66-9.28$ \\
\hline 6 & $1.02-4,773$ & $3.40-194$ & $.00-7.82$ & $29.5-46.0$ & $330-1,818$ & $7.00-92.0$ & $1.43-18.0$ \\
\hline 7 & $58-2,467$ & $4.10-156$ & $.01-13.4$ & $29.5-41.0$ & $349-1,489$ & $7.00-56.0$ & $1.79-17.5$ \\
\hline
\end{tabular}


percent. To test variables without a constant added to or subtracted from them (for example, drainage area), the regional mean value of each variable was used to compute a "base" 50-year peak discharge. The variable being tested was then varied by the above percentages, and the resulting changes (in percent) of 50-year peak-discharge were tabulated. For variables to which constants were added or subtracted, such as mean annual precipitation (P) and storage (ST), a regional "low" and "high" value was used to compute a "base" 50-year peak-discharge because errors in computed discharges will be affected differently, depending on the magnitude of the basin characteristic being tested. For testing purposes, regional 10th- and 90th-percentile values of these characteristics were used as low and high values. As table 7 shows, mean annual precipitation was the variable to which peak discharges were most sensitive, and drainage area was the next. Although mean annual precipitation is the most sensitive variable, selection of a precipitation value from plate 1 that is in error by more than 10 percent is unlikely.

\section{SUGGESTIONS FOR FURTHER STUDY}

Standard errors of the regional estimating equations presented in this study are less than those obtained from equations published in 1979 as a result of the addition of small-stream gaging stations to the network, extended record of annual peak discharges, and improved analytical methods. The study of several factors related to flood-frequency relations, discussed below, could decrease errors in future analyses still further, however.

\section{Skewness Coefficient}

Weighting the skewness coefficient computed from station records with a generalized skewness coefficient reduces the bias caused by stations with relatively short periods of record (U.S. Water Resources Council, 1981). This study used 178 gaging stations on rural, unregulated streams with 25 or more years of record; these included records for streams before reservoir construction. A comparison of skew values from the U.S. Water Resources Council (1981) national generalized skew map with systematic-record station skews, for stations in each of the eight hydrologic regions of New York, is given in figure 14 (p. 42). Some regional bias and significant errors are indicated by these graphs; therefore a regionalized State skew map is needed before future updates of the New York floodfrequency relations are undertaken.

\section{Precipitation Maps}

The flood-frequency relations for New York show mean annual precipitation to be a critical factor in determining peak discharges. An improved mean-annual-precipitation map and maps of shorter duration precipitation (such as a 24-hour, 2-year rainfall-intensity map) could significantly increase the accuracy and predictive ability of the flood-frequency relations.

\section{Small-Stream Data}

Historical flood data on small streams could alter and improve the current flood-frequency relations but is generally unavailable. Additional information might be available from floodinsurance studies, government agencies, public libraries, or engineering records; such information would be best collected and documented in a format similar to that used by Robideau and others (1984).

Expansion of the current annual peak-discharge gaging-station network to include additional small-stream sites (particularly sites with drainage areas less than $1.0 \mathrm{mi}^{2}$ ) could improve the accuracy of computed peak discharges for these sites. A rainfall-runoff data network with subsequent modeling could be used to supplement the peak-discharge data base for very small streams. 


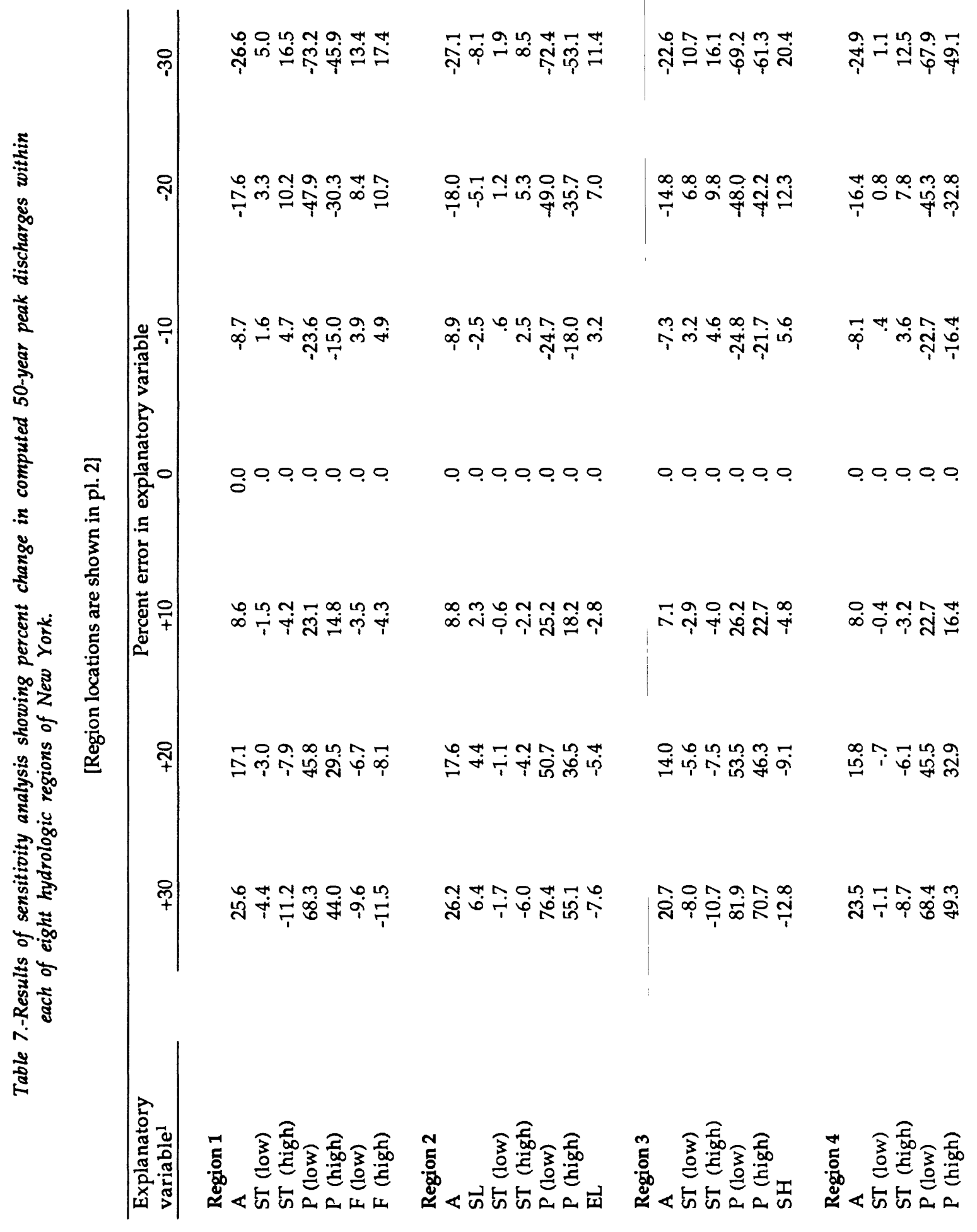




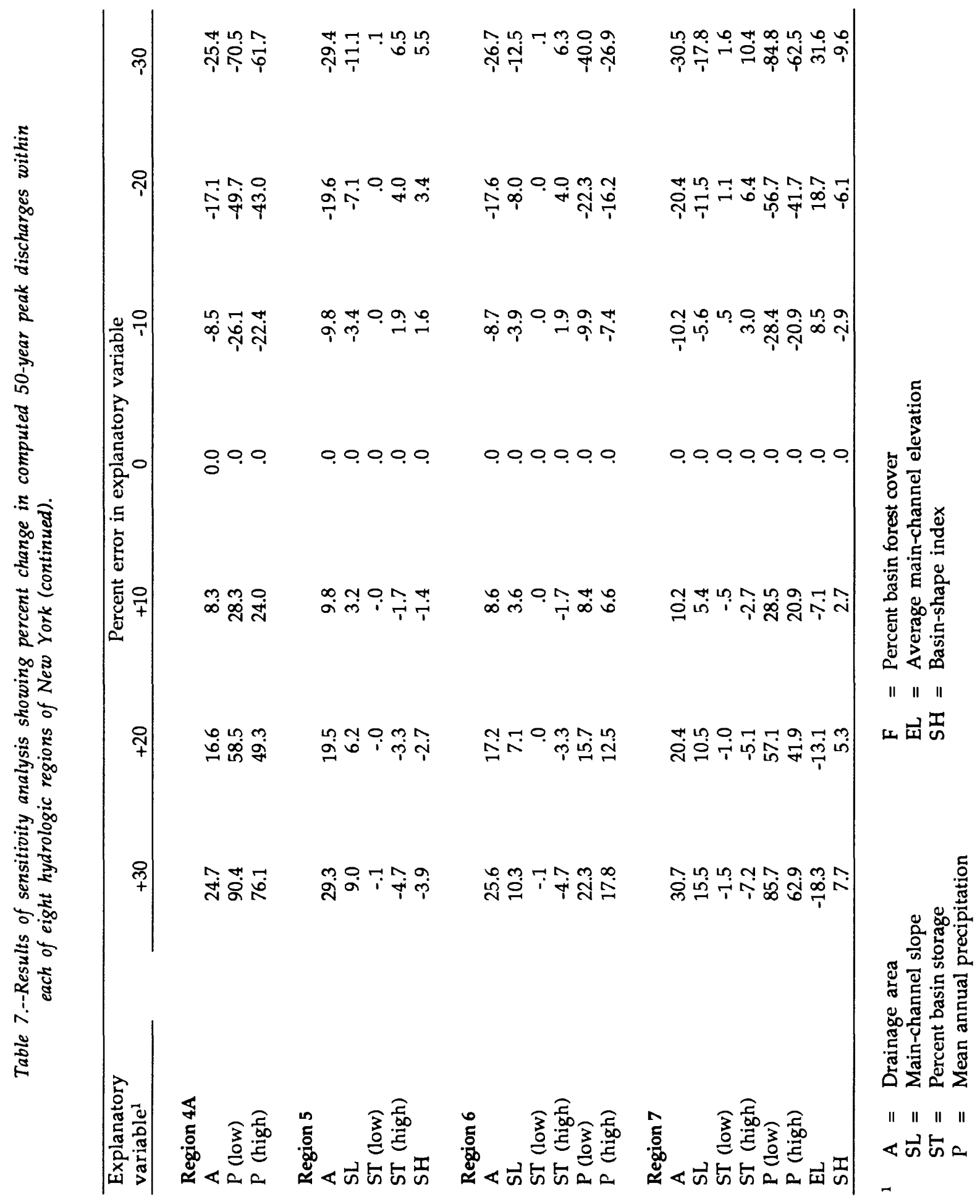



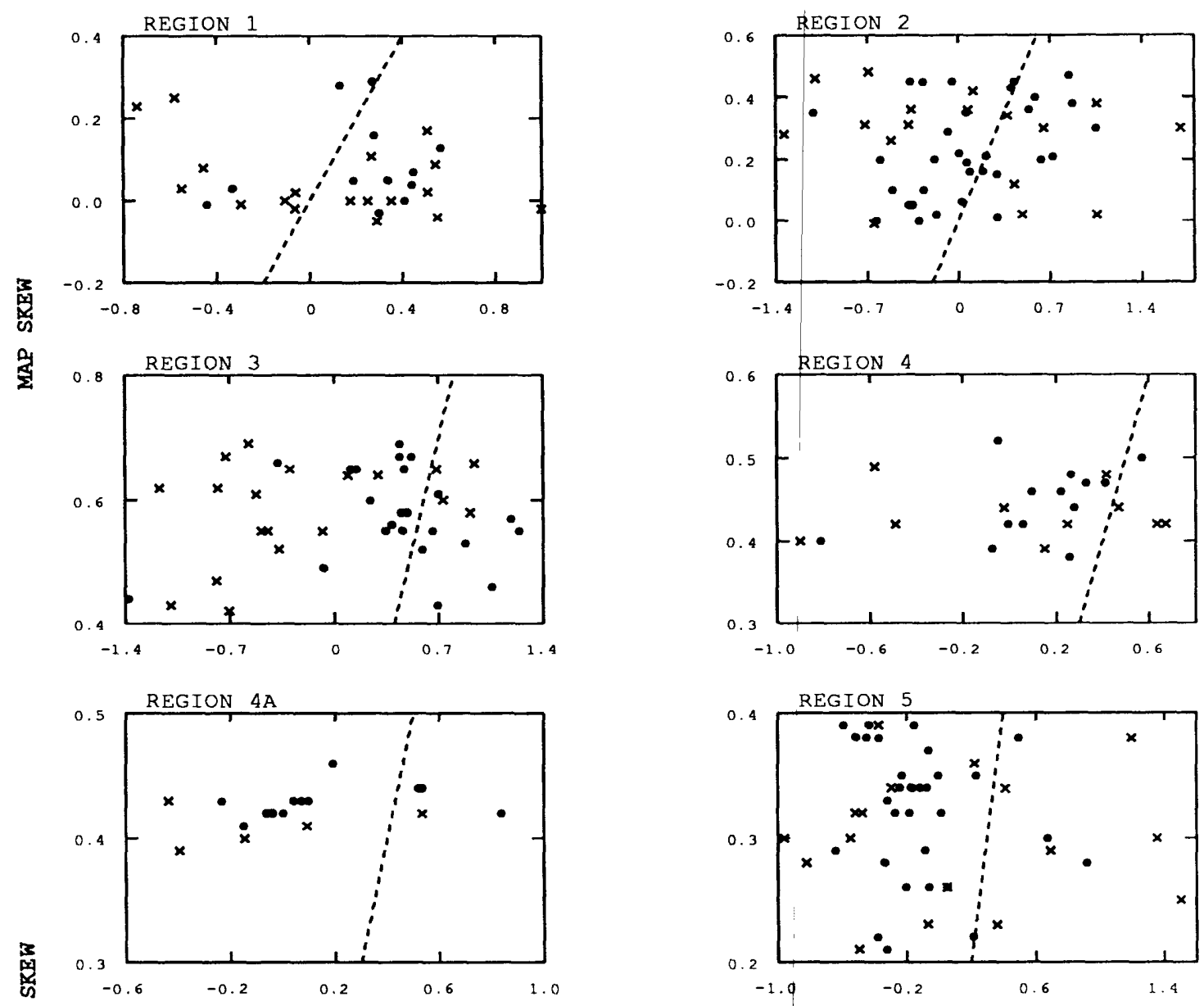

然
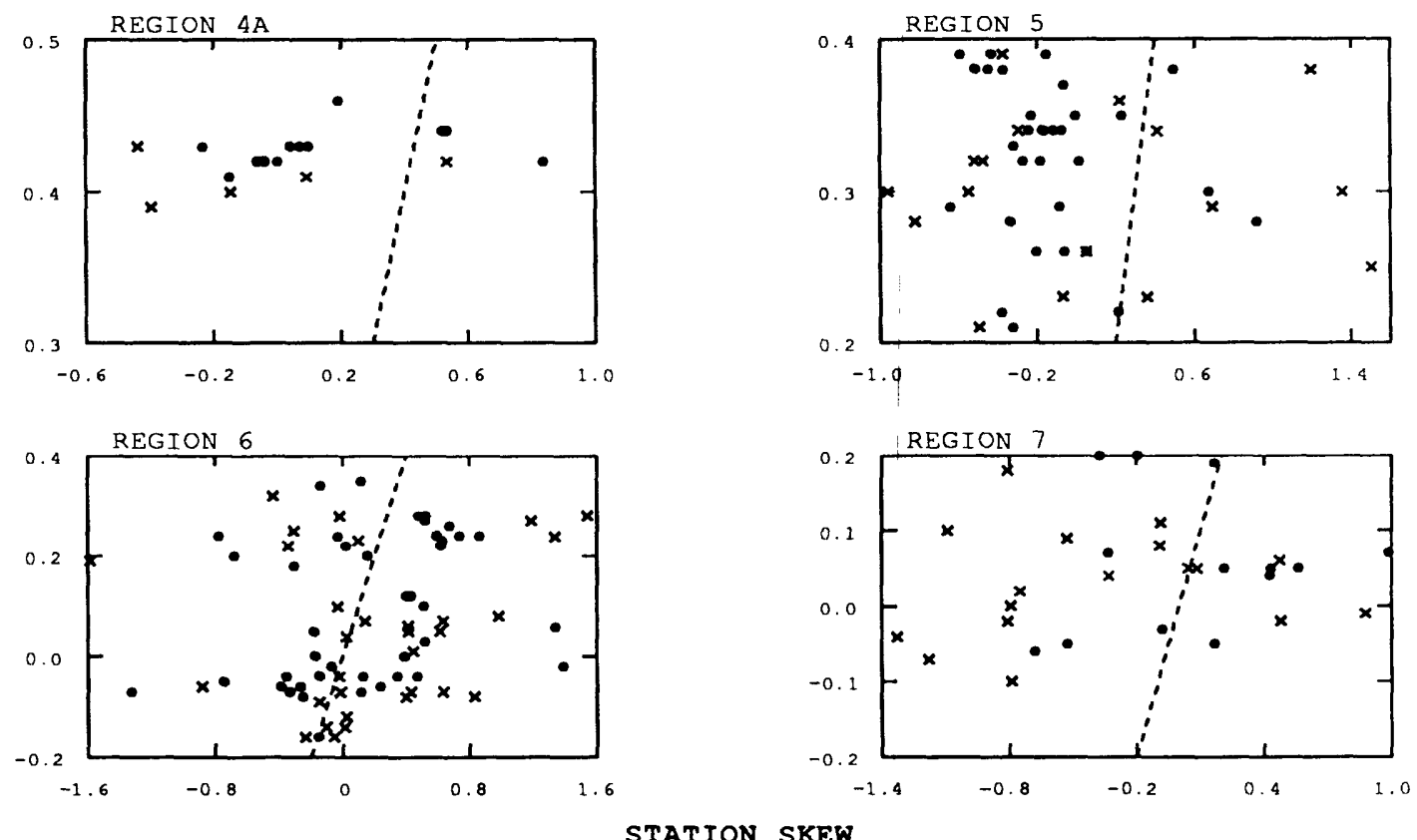

STATION SKEW

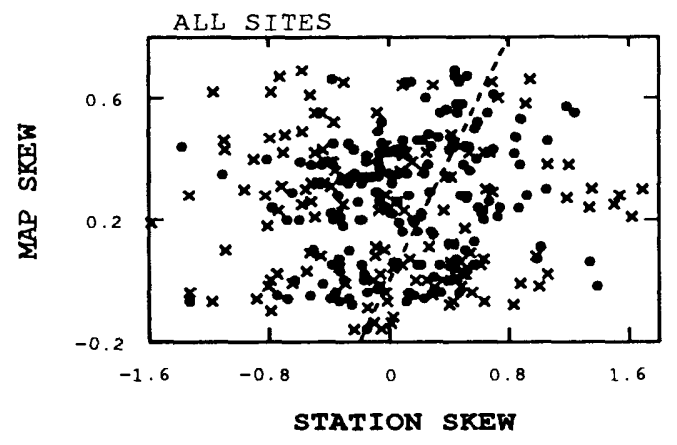

EXPLANATION

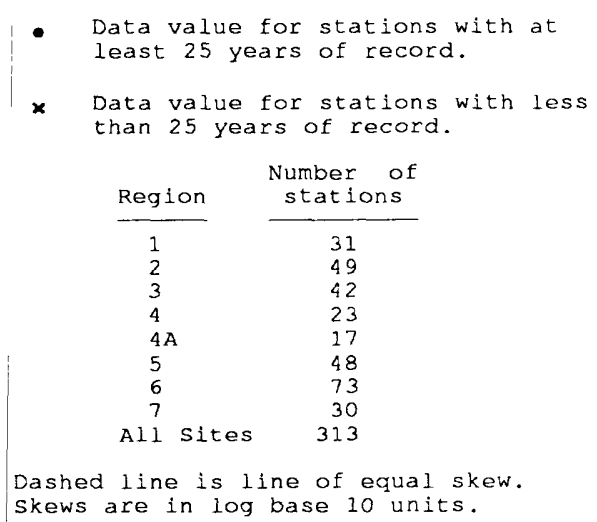

Figure 14.--Comparison of station skews with generalized map skews from U.S. Water Resources Council (1981) for gaging stations within eight hydrologic regions of New York. (Locations of regions are shown on pl. 2.) 


\section{Other Factors}

Study of several other factors could potentially improve the flood-frequency relations for New York. These factors include (1) the effect of mixed populations in annual peak-discharge data analysis (for example, floods caused by thunderstorms combined with floods from snowmelt or hurricanes), (2) effects of additional basin characteristics (for example, basin lag factors, channel width, indices from land-use maps, rainfall indices) in the regression analyses to account for unexplained variability in peak discharges, and (3) the effect of regulation, with development of a criterion for selecting or rejecting peak-discharge records on the basis of storage effects.

\section{SUMMARY}

This report presents regional regression equations based on generalized least-squares regression analysis for calculating the magnitude and frequency of floods on rural, unregulated streams in New York, excluding Long Island. Procedures for estimating peak discharges with recurrence intervals of 2,5, $10,25,50,100$, and 500 years for eight hydrologic regions of New York are given; the procedures depend on whether the estimate is for a gaged or ungaged basin and whether the basin crosses hydrologic region boundaries or extends into an adjacent State. Estimated standard error of prediction for the regression equations range from 17 to 51 percent. Tables and illustrations summarize the data and give final estimates of peak discharges at the 313 gaging stations used for the analyses. Examples of discharge computations are provided, as are discussions of the limitations and accuracy of the estimating equations and the relative importance of the significant variables (sensitivity analysis).

Several suggestions for additional study are discussed, including development of a generalized skew map for New York. Alternative peak-discharge estimating equations, based on drainage area only, are included. These equations provide estimates of peak discharges that are easier to compute, but less accurate, than those calculated through the full-regression equations.

\section{SELECTED REFERENCES}

Choquette, A. F., 1988, Regionalization of peak discharges for streams in Kentucky: U.S. Geological Survey Water Resources Investigations Report 87-4209, 105 p.

Clement, R. W., 1987, Floods in Kansas and techniques for estimating their magnitude and frequency on unregulated streams: U.S. Geological Survey Water Resources Investigations Report 87-4008, $50 \mathrm{p}$.

Cline, M.G., 1961, Soils and soil associations of New York: Ithaca, N.Y., New York State College of Agriculture at Cornell University; Cornell Extension Bulletin 930; 64 p.

Darmer, K. I., 1970, A proposed streamflow data program for New York: U.S. Geological Survey openfile report, $29 \mathrm{p}$.

Dempster, G. R., Jr., 1983, Instructions for streamflow/basin characteristics file: U.S. Geological Survey National Water Data Storage and Retrieval System, v. 4, chapter II (unpaginated).

Fenneman, N. M., 1938, Physiography of eastern United States: New York, McGraw-Hill, 714 p.

Flippo, H. N., Jr. 1977, Floods in Pennsylvania: Pennsylvania Department of Natural Resources, Water Resources Bulletin 13, 59 p.

Hardison, C. H., 1971, Prediction error of regression estimates of streamflow characteristics at ungaged streams, in Geological Survey Research 1971: U.S. Geological Survey Professional Paper 750-C, p. C228-C236. 


\section{SELECTED REFERENCES (continued)}

Hunt, O.P. 1969, Mean annual precipitation map for New York for the period 1931-60: Unpublished map on file in Albany, N.Y. office of the U.S. Geological Survey.

Iman, R. L., and Conover, W. J., 1983, A modern approach to statistics: New York, John Wiley, 497 p.

Johnson, C. G., and Tasker, G. D., 1974, Progress report on flood magnitude and frequency of Vermont streams: U.S Geological Survey Open-File report, 74-130, 36 p.

Kirby, William, 1981, Annual flood frequency analysis using U.S. Water Resources Council guidelines (Program J407): U.S. Geological Survey National Water Storage and Retrieval System, v. 4, chapter I, section C, $57 \mathrm{p}$.

Koch, R.W., and Smillie, G.M., 1986, Bias in hydrologic prediction using log-transformed regression models: Water Resources Bulletin, v. 22, no. 5, p. 717-723.

Ku, H. F.H., Randall, A.D., and MacNish, R.D., 1975, Streamflow in the New York part of the Susquehanna River basin: New York State Department of Environmental Conservation, Bulletin 71, $130 \mathrm{p}$.

Lumia, Richard, 1984, Flood-discharge profiles of selected streams in Rockland County, New York: U.S. Geological Survey Water Resources Investigations Report 84-4049, 32 p.

Lyford, F.P., Dysart, J.E., Randall, A.D., and Kontis, A.L., 1984, Glacial aquifer systems in the northeastern United States-a study plan: U.S. Geological Survey Open-File Report 83-928, 33 p.

Minitab, Inc., 1985, Minitab reference manual: State College, Pa., Minitab, Inc., 232 p.

National Oceanic and Atmospheric Administration, 1980, Climates of the States, volume 1, Alabama North Dakota: p. 530-539.

New York State Economic Development Board, 1976, LUNR Inventory-what it is and how it is used: Albany, N.Y., New York State Economic Development Board, 16 p.

Robideau, J. A., Burke, P. M., and Lumia, Richard, 1984, Maximum known stages and discharges of New York streams through September 1983: U.S. Geological Survey Open-File Report 83-927, 83 p.

Robison, L. F., 1961, Floods in New York-magnitude and frequency: U.S. Geological Survey Circular $454,10 \mathrm{p}$.

SAS [Statistical Analysis System] Institute, Inc., 1982, SAS user's guide--statistics, 1982 ed.: Cary, N.C., SAS Institute, Inc., 584 p.

Sauer, V. B., Thomas, W. O., Jr., Stricker, V. A., and Wilson, K. V., 1983, Flood characteristics of urban watersheds in the United States: U.S. Geological Survey Water-Supply Paper 2207, 63 p.

Speer, P. R., and Gamble, C. R., 1965, Magnitude and frequency of floods in the United States, Part 3-A, Ohio River basin except Cumberland and Tennessee River basins: U.S Geological Survey WaterSupply Paper 1675, 630 p.

Stankowski, S. J., 1974, Magnitude and frequency of floods in New Jersey, with effects of urbanization: New Jersey Department of Environmental Protection Division of Water Resources, Special Report $38,46 \mathrm{p}$. 


\section{SELECTED REFERENCES (continued)}

Stedfast, D. A., 1986, Evaluation of six methods for estimating magnitude and frequency of peak discharges of urban streams in New York: U.S. Geological Survey Water Resources Investigations Report 84-4350, 24 p.

Stedinger, J. R., and Tasker, G. D., 1985, Regional hydrologic analysis 1, ordinary, weighted, and generalized least squares compared: Water Resources Research, v. 21, no. 9, p. 1421-1432.

Tasker, G. D., 1982, Simplified testing of hydrologic regression regions: American Society of Civil Engineers, Journal of Hydraulics Division, v. 108, no HY10, p. 1218-1222.

Tasker, G. D., and Stedinger, J. R., 1989, An operational GLS model for hydrologic regression: Journal of Hydrology, v. 111, p. 361-375.

Thomas, W. O., Jr., 1980, Comparison of procedures for weighting flood-frequency curves: Water Resources Bulletin, April-June, 1980, p. 23-30.

Tice, Richard H., 1968, Magnitude and frequency of floods in the United States, part 1-B, North Atlantic Slope basins, New York to York River: U.S. Geological Survey Water-Supply Paper 1672, $585 \mathrm{p}$.

U.S. Department of Commerce, Weather Bureau, 1961, Rainfall frequency atlas of the United States: Washington, D.C., Technical Paper no. 40, 115 p.

U.S. Water Resources Council, 1981, Guidelines for determining floodflow frequency: Hydrology Subcommittee Bulletin 17B, 28 p., appendix.

Wagner, L. A., 1982, Drainage areas of New York streams, by river basins-a stream gazetteer, Part 1, data compiled as of October 1980: U.S. Geological Survey Open-File Report 81-1055, 359 p.

Wandle, S. W., Jr., 1977, Estimating the magnitude and frequency of floods on natural-flow streams in Massachusetts: U.S. Geological Survey Water-Resources Investigations 77-39, 26 p.

Wandle, W.S. Jr., 1983, Estimating peak discharges of small, rural streams in Massachusetts: U.S. Geological Survey Water Supply Paper 2214, 26 p.

Weiss, L. A., 1983, Evaluation and design of a streamflow-data network for Connecticut: Connecticut Water Resources Bulletin No. 36, 30 p.

Wiitala, S. W., 1965, Magnitude and frequency of floods in the United States, Part 4, St. Lawrence River basin: U.S. Geological Survey Water-Supply Paper 1677, 357 p.

Zembrzuski, T. J., Jr., and Dunn, B., 1979, Techniques for estimating magnitude and frequency of floods on rural, unregulated streams in New York State excluding Long Island: U.S. Geological Survey Water-Resources Investigations 79-83, 66 p. 


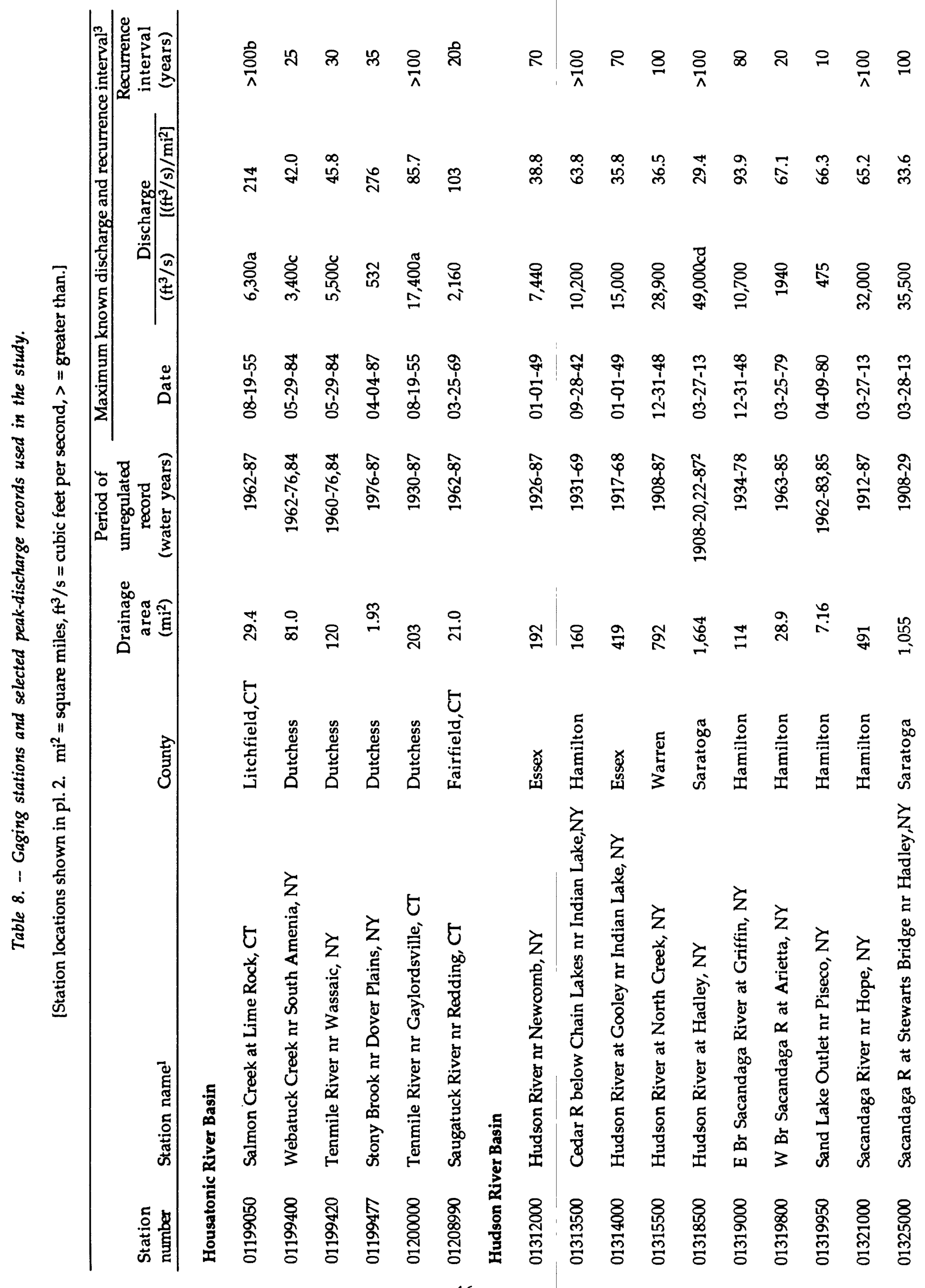




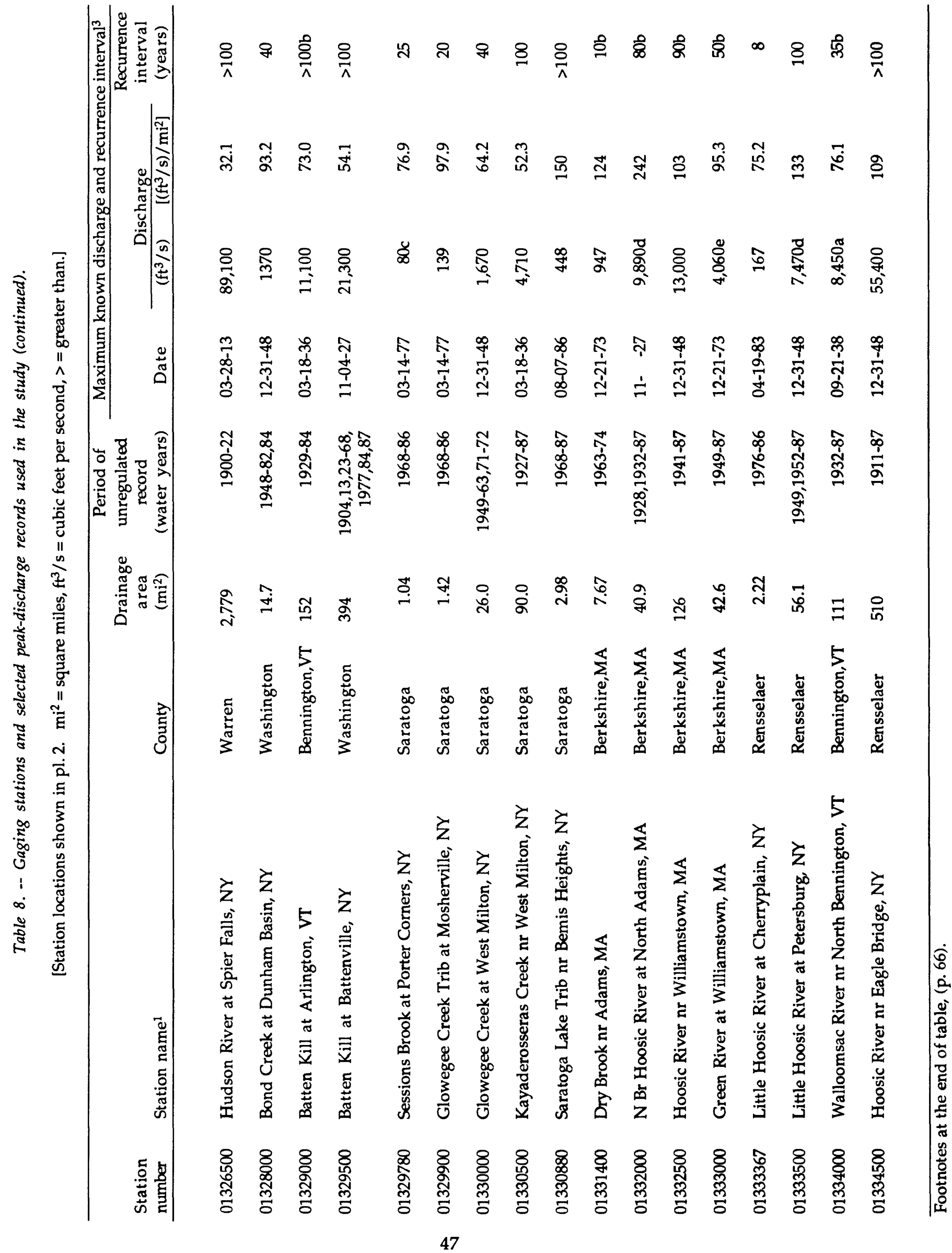




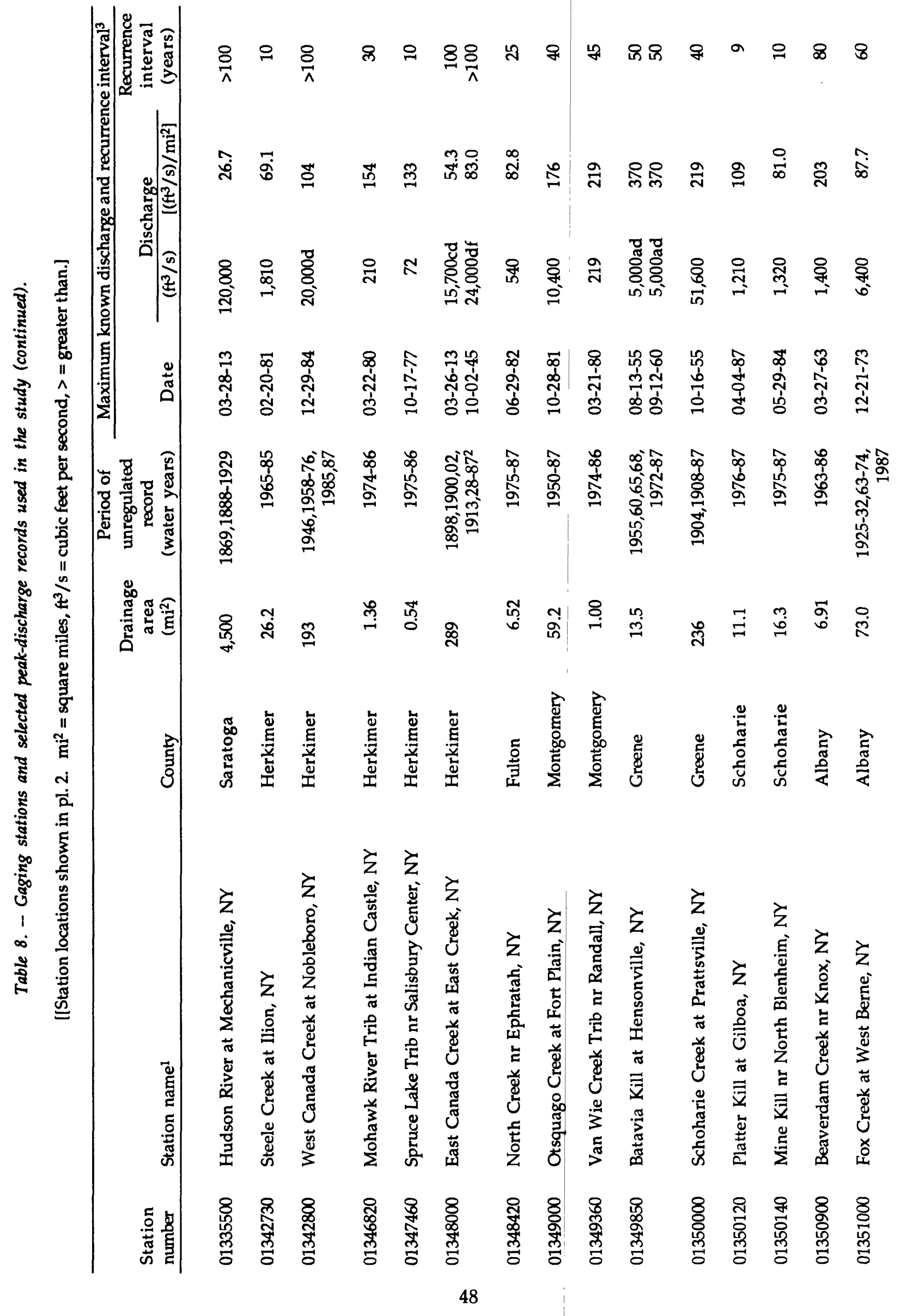






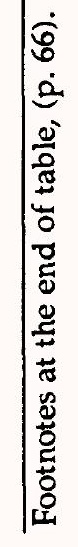




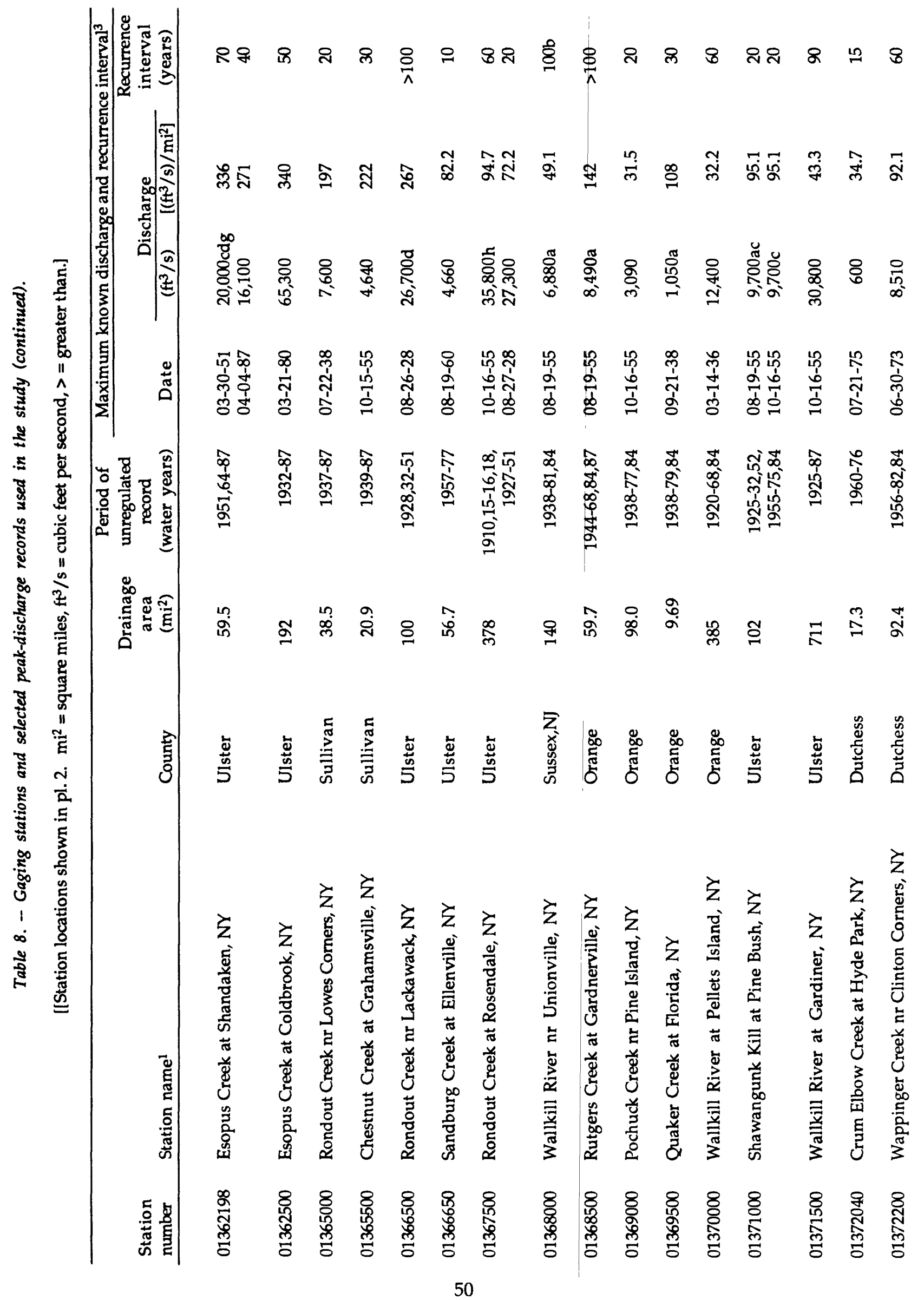




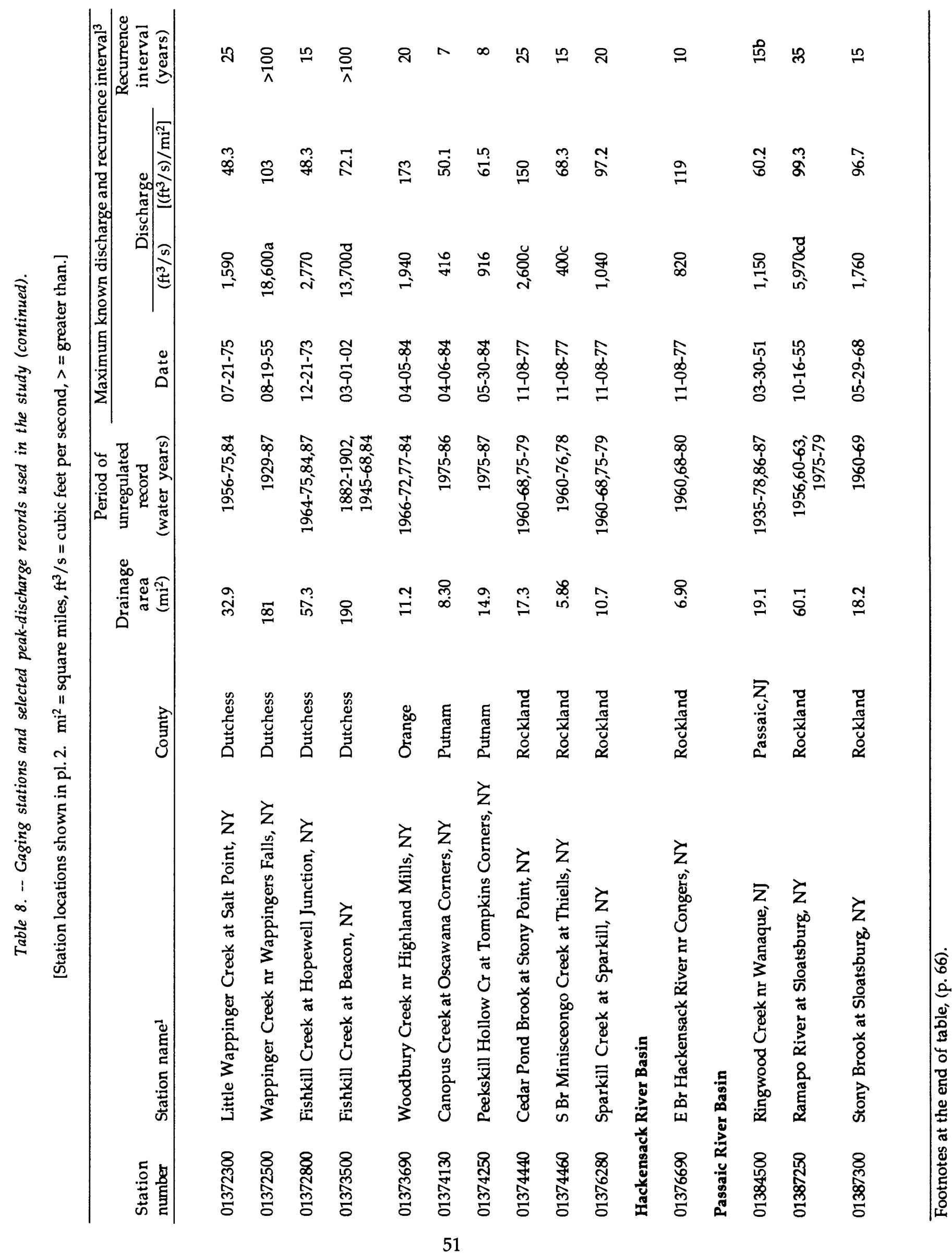




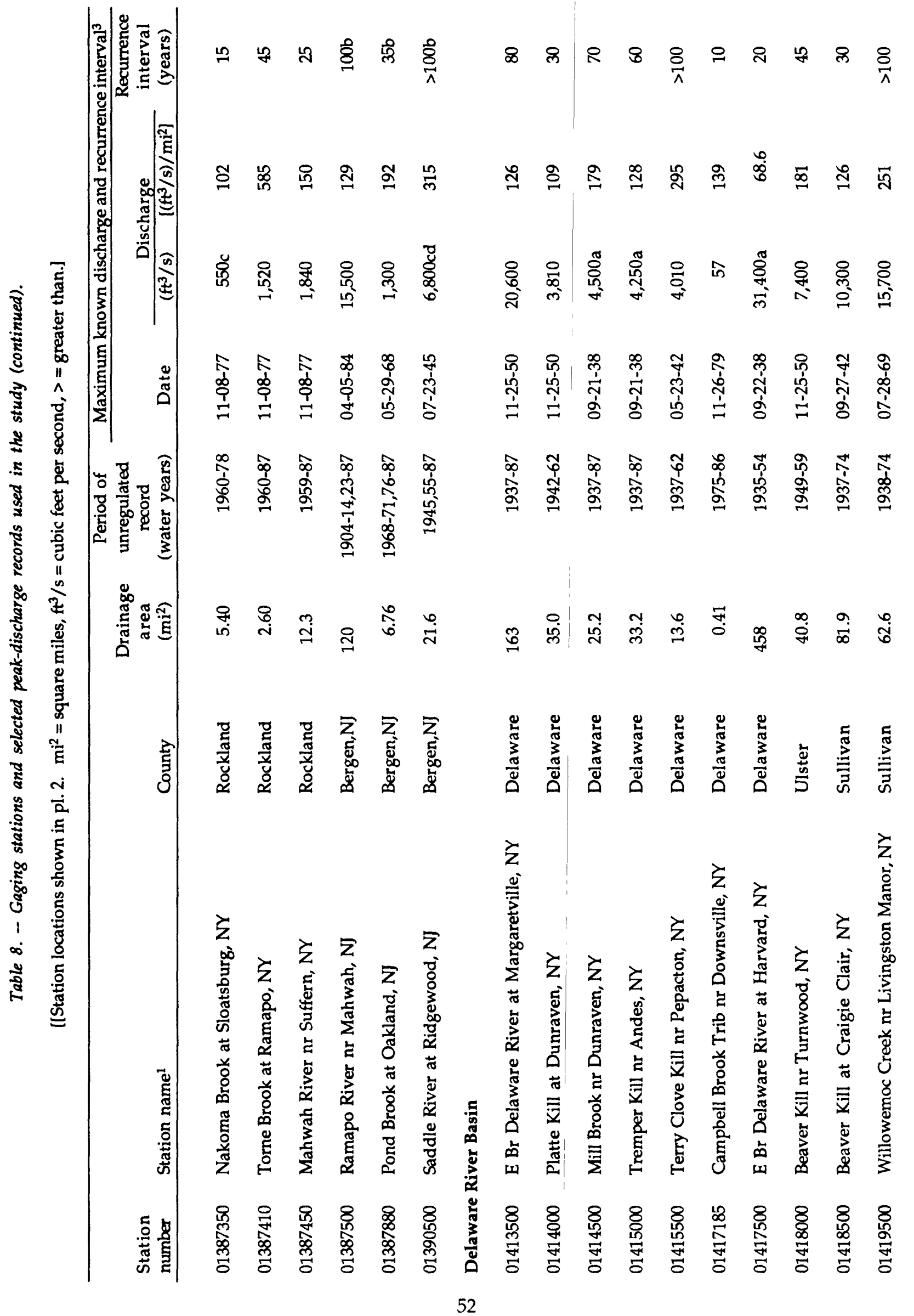




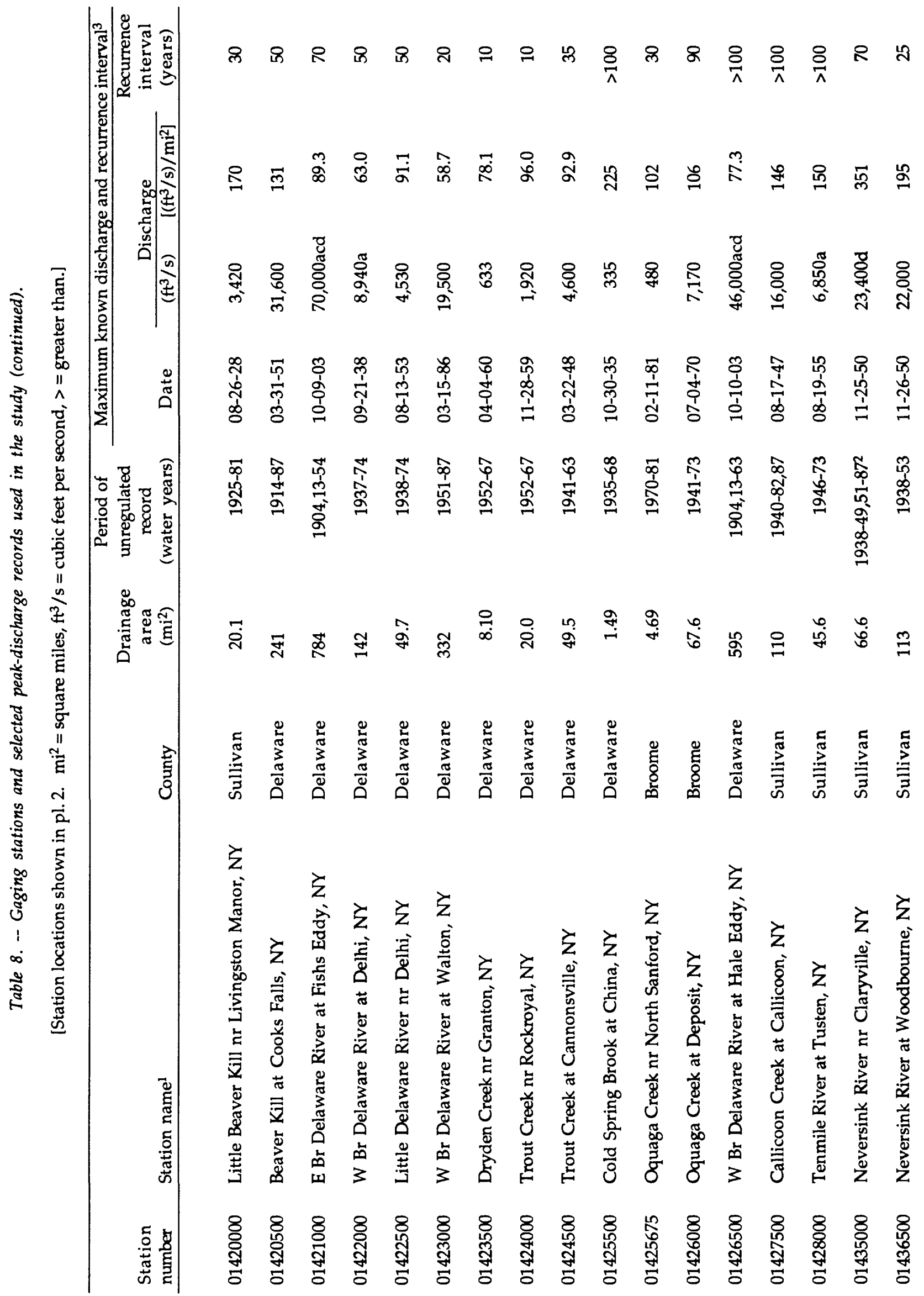




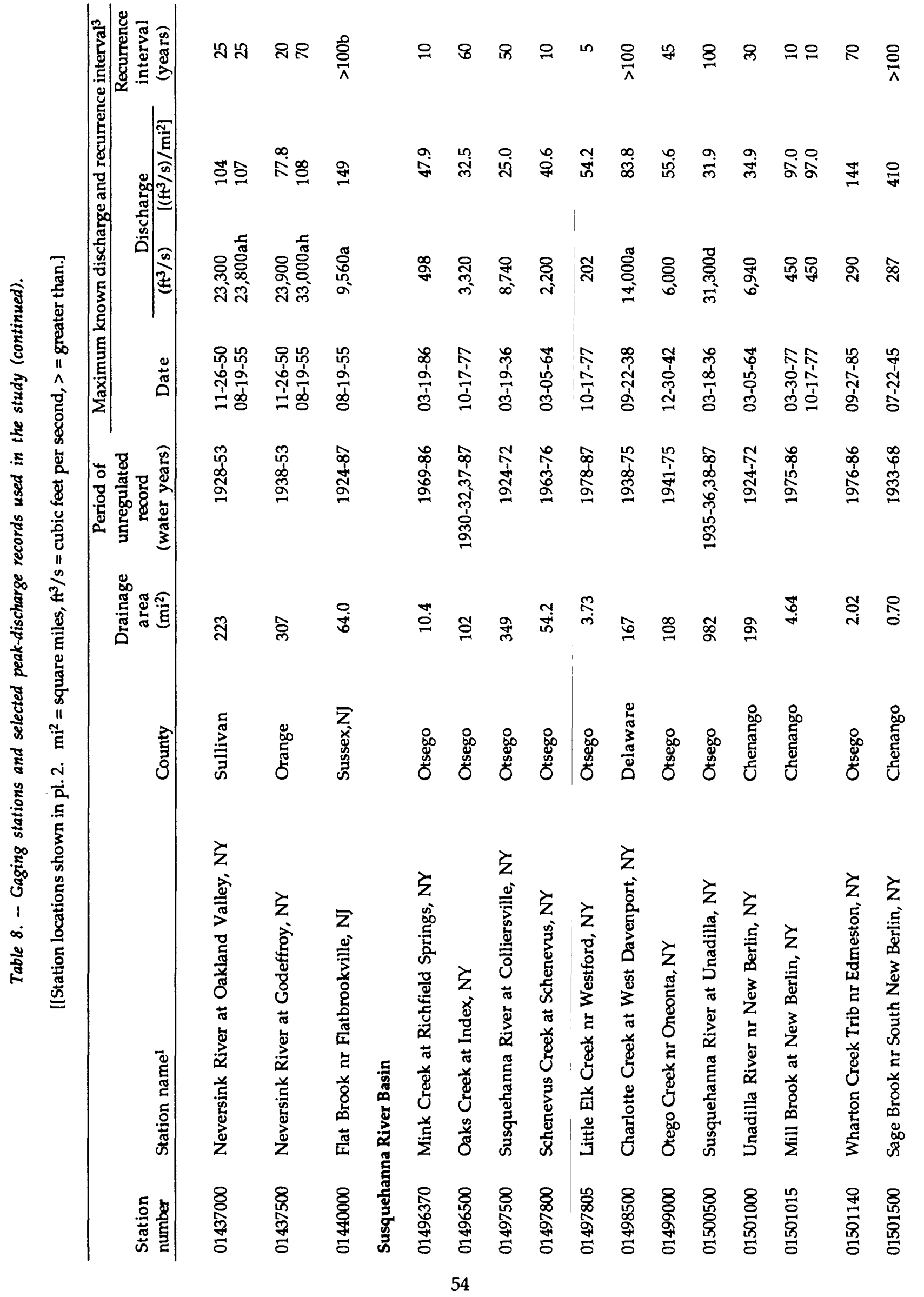




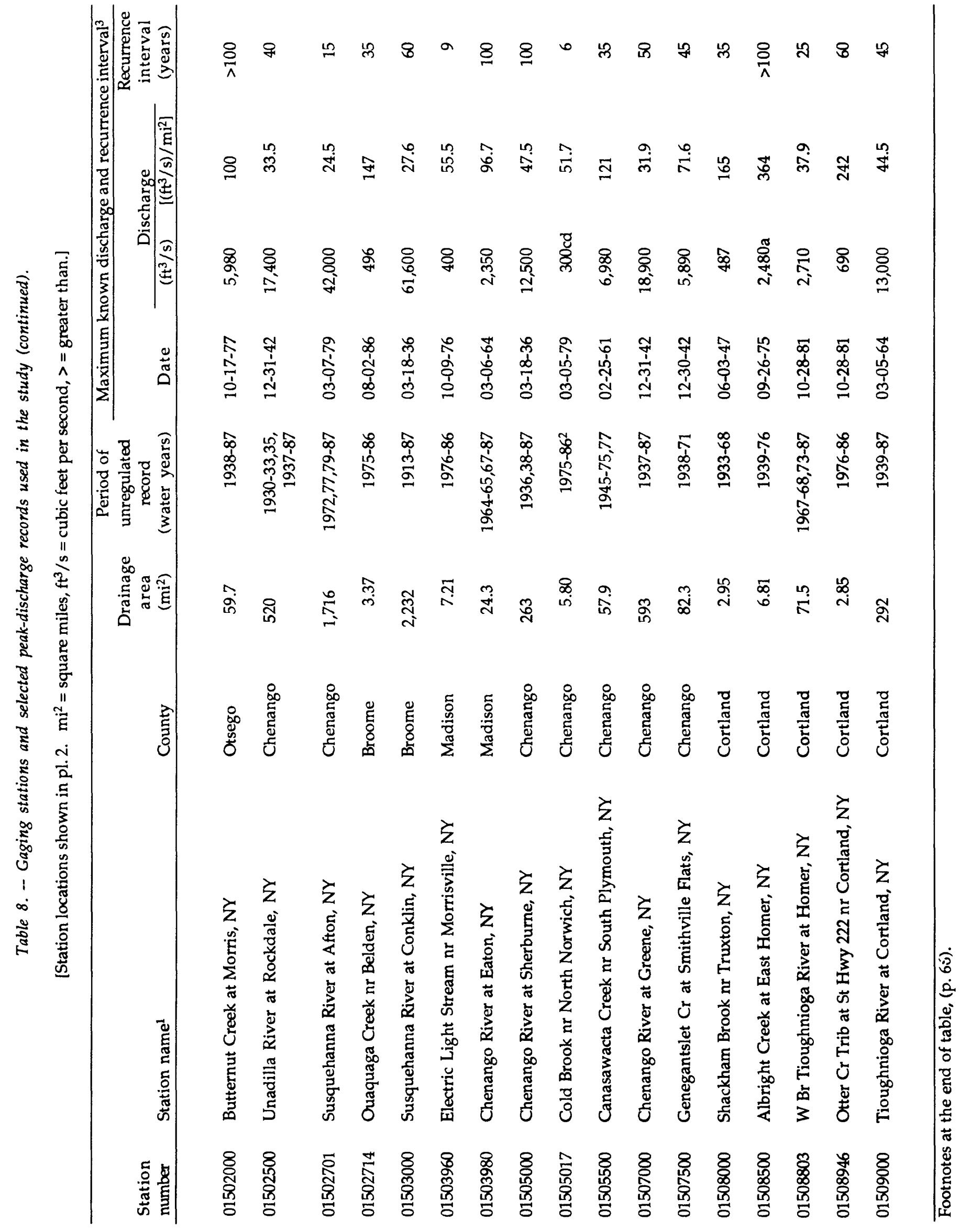




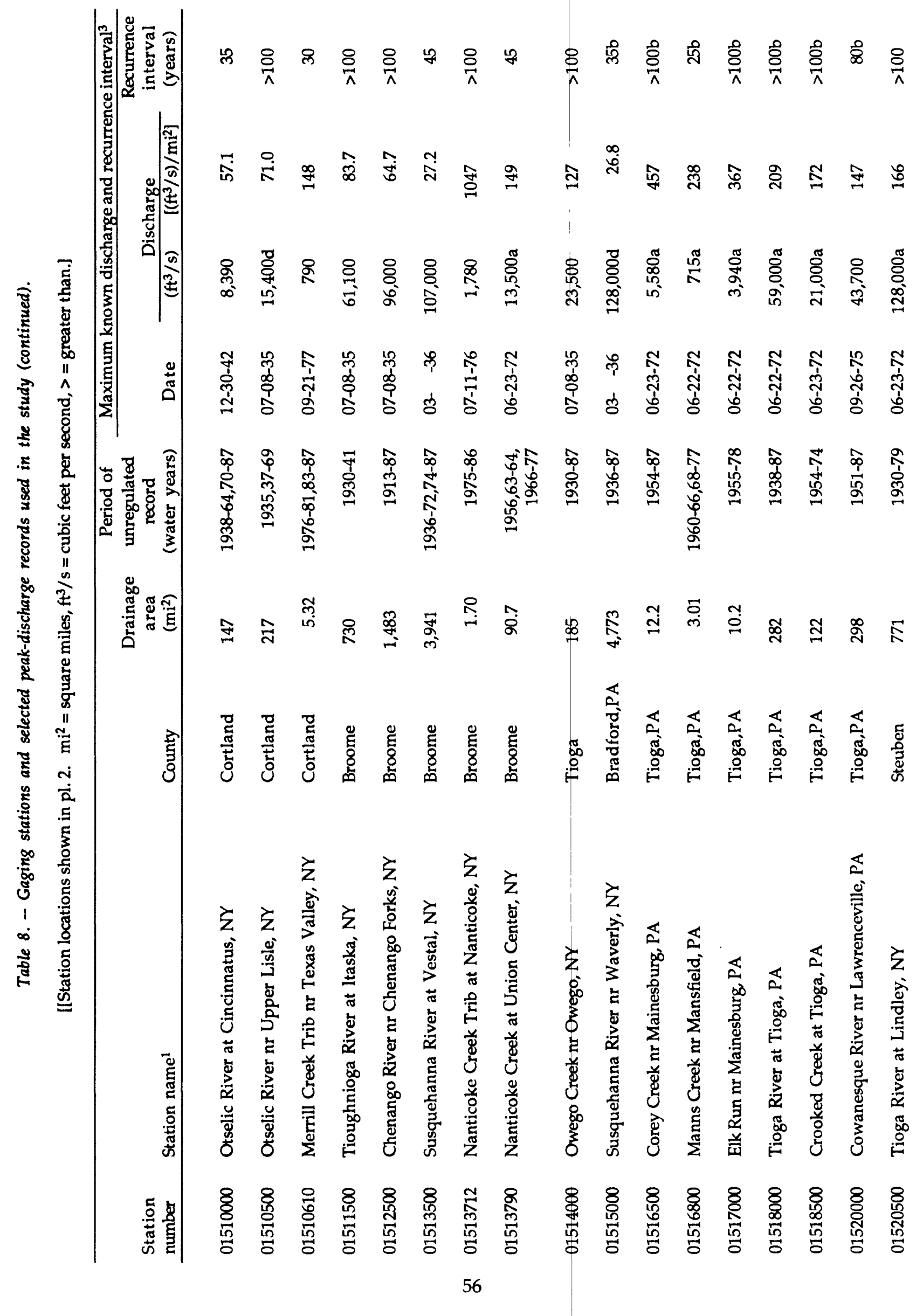




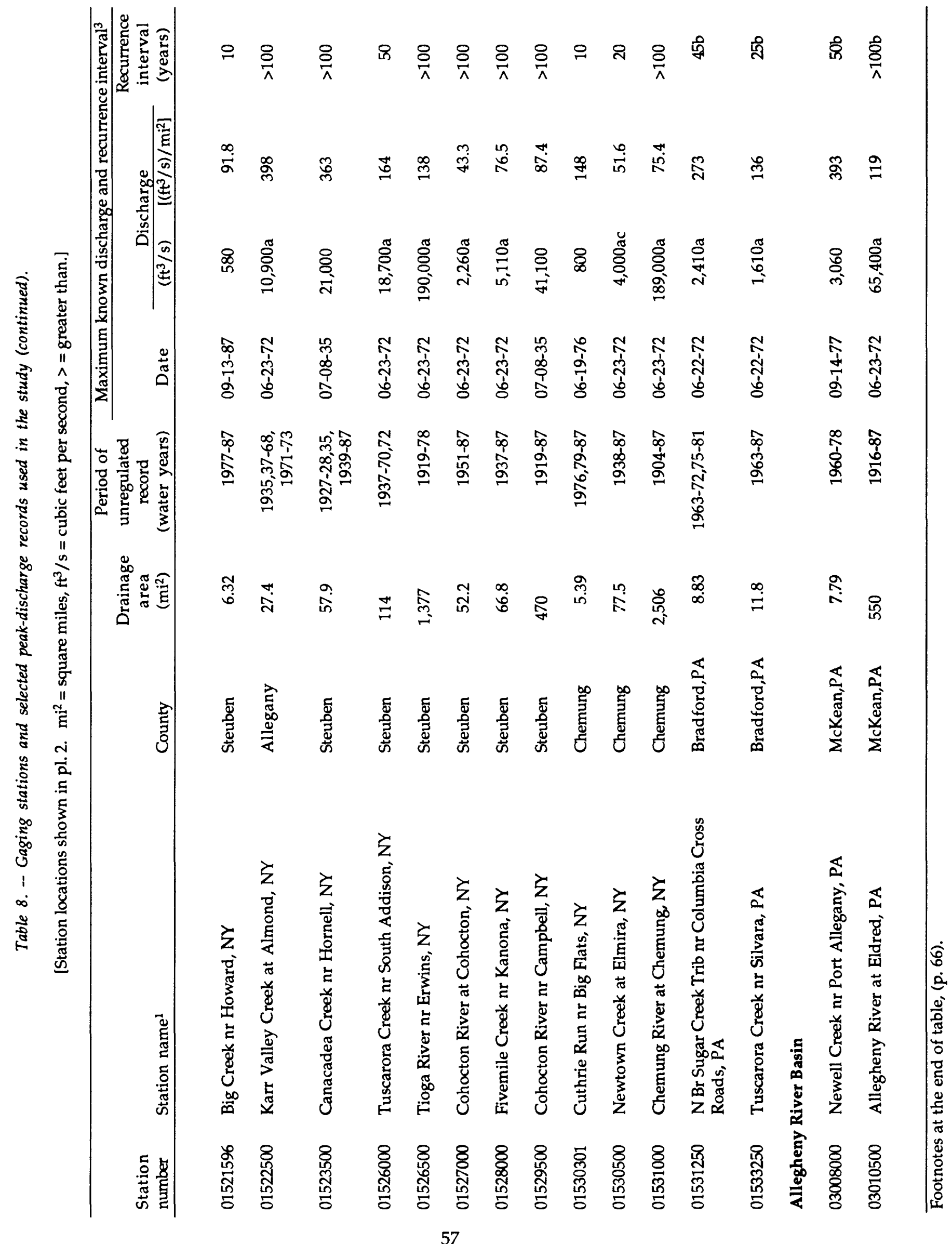




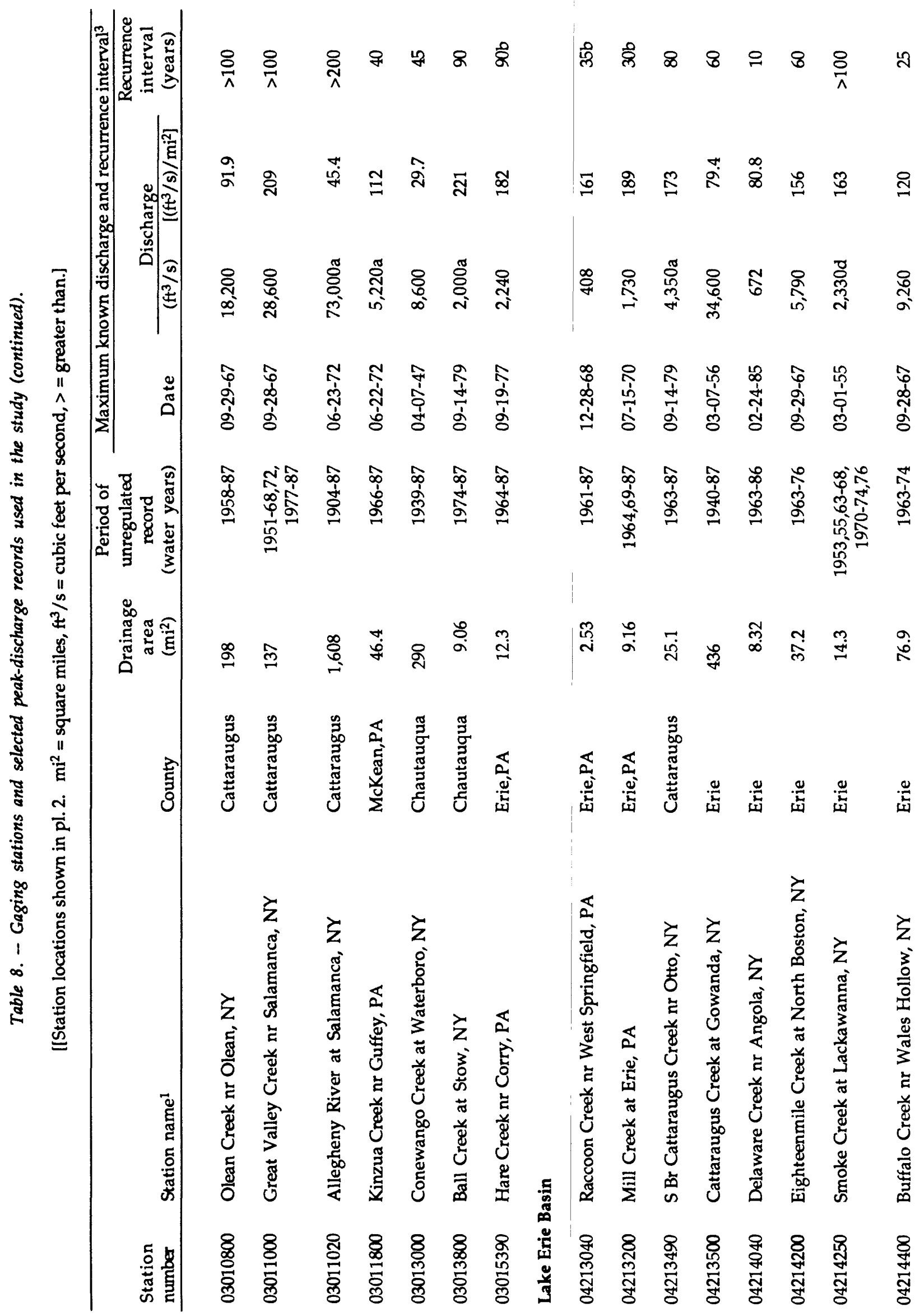




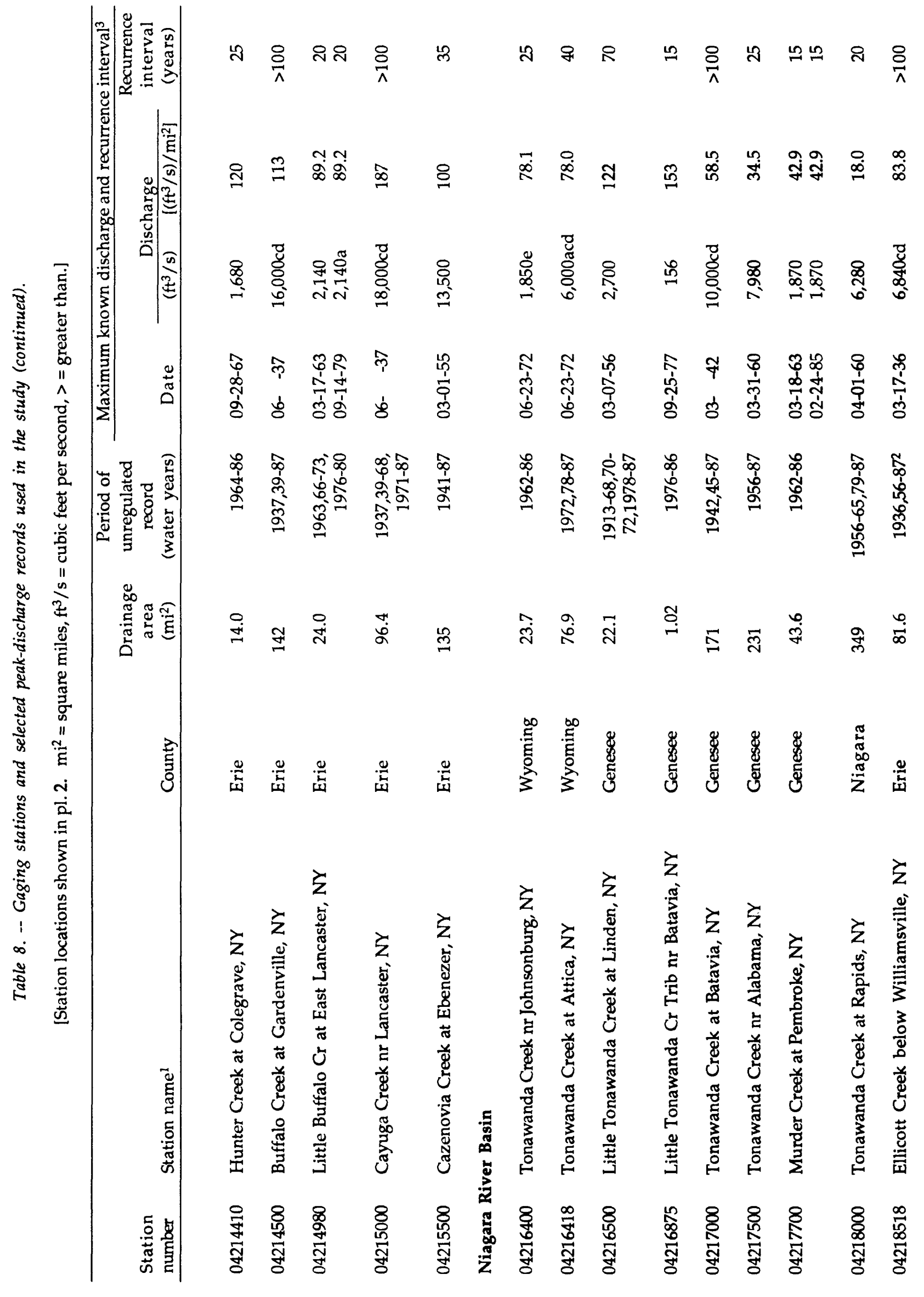




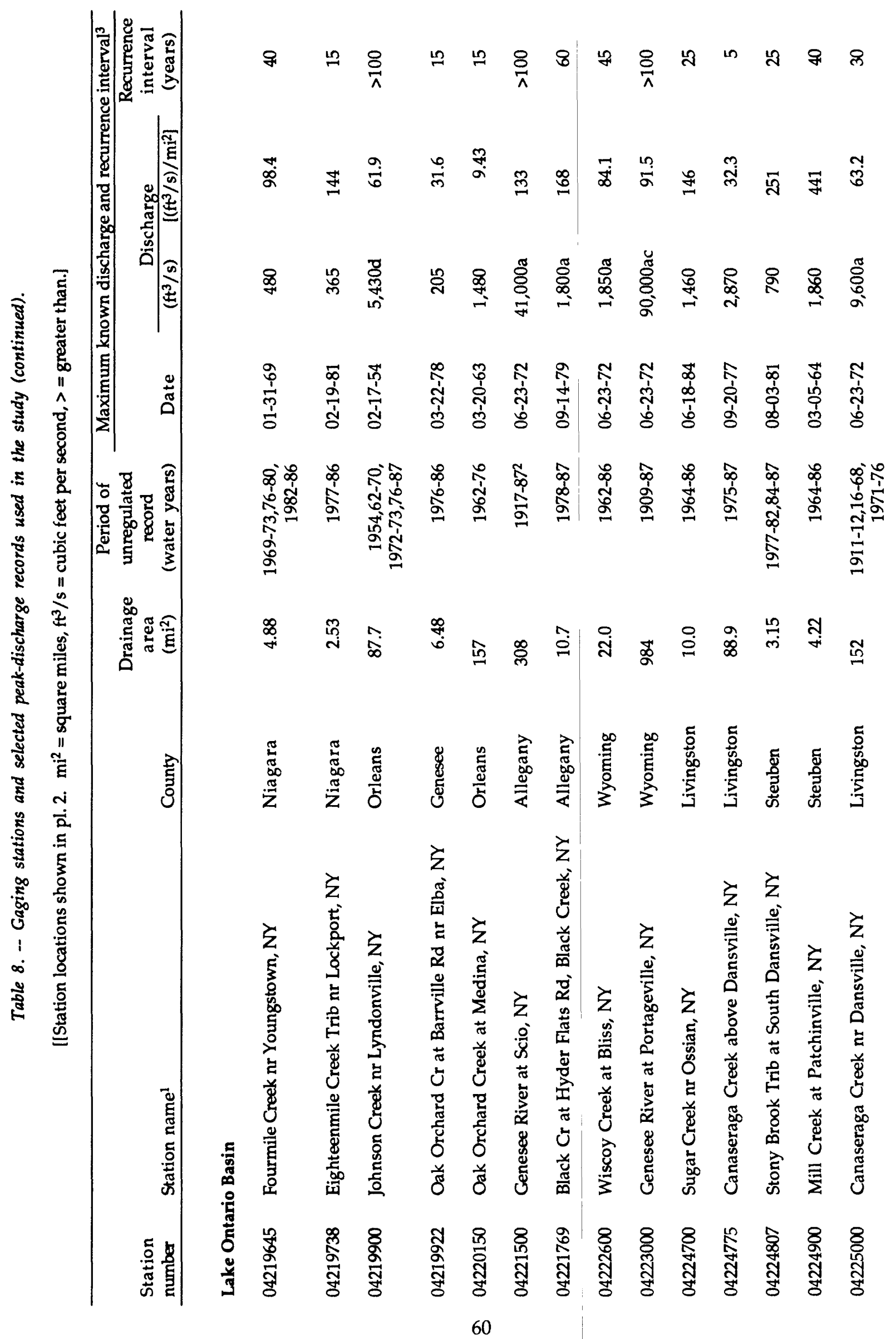




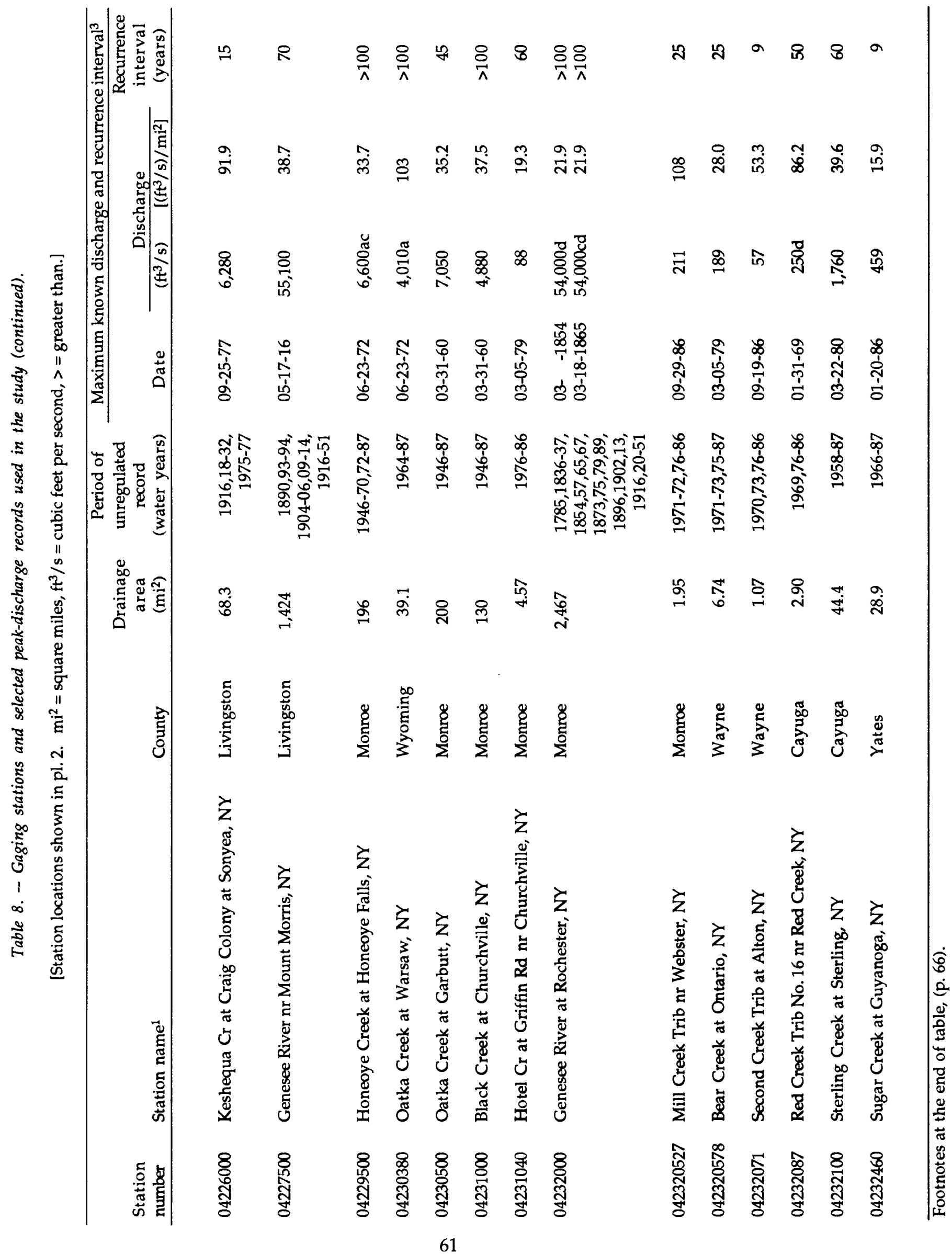




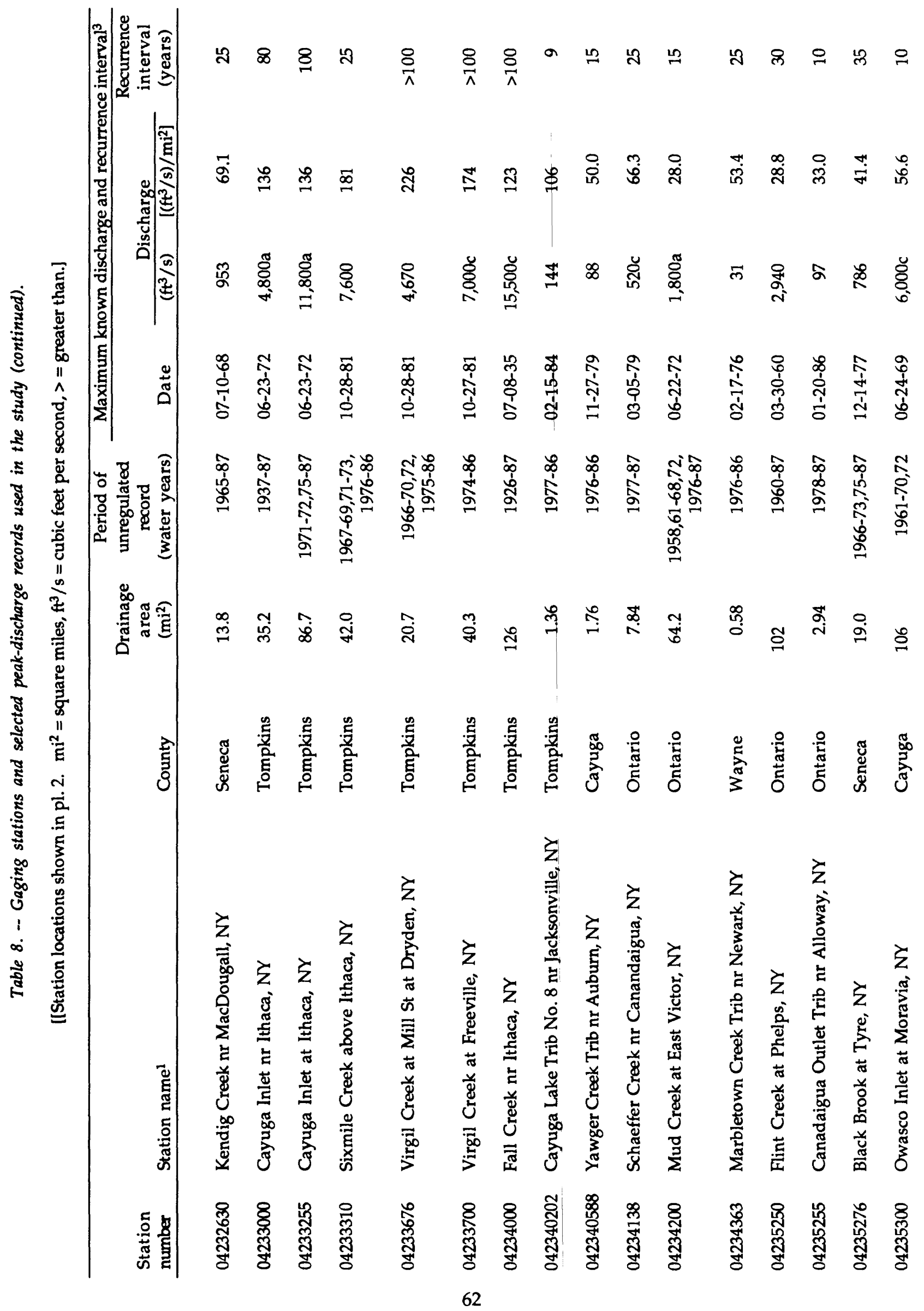









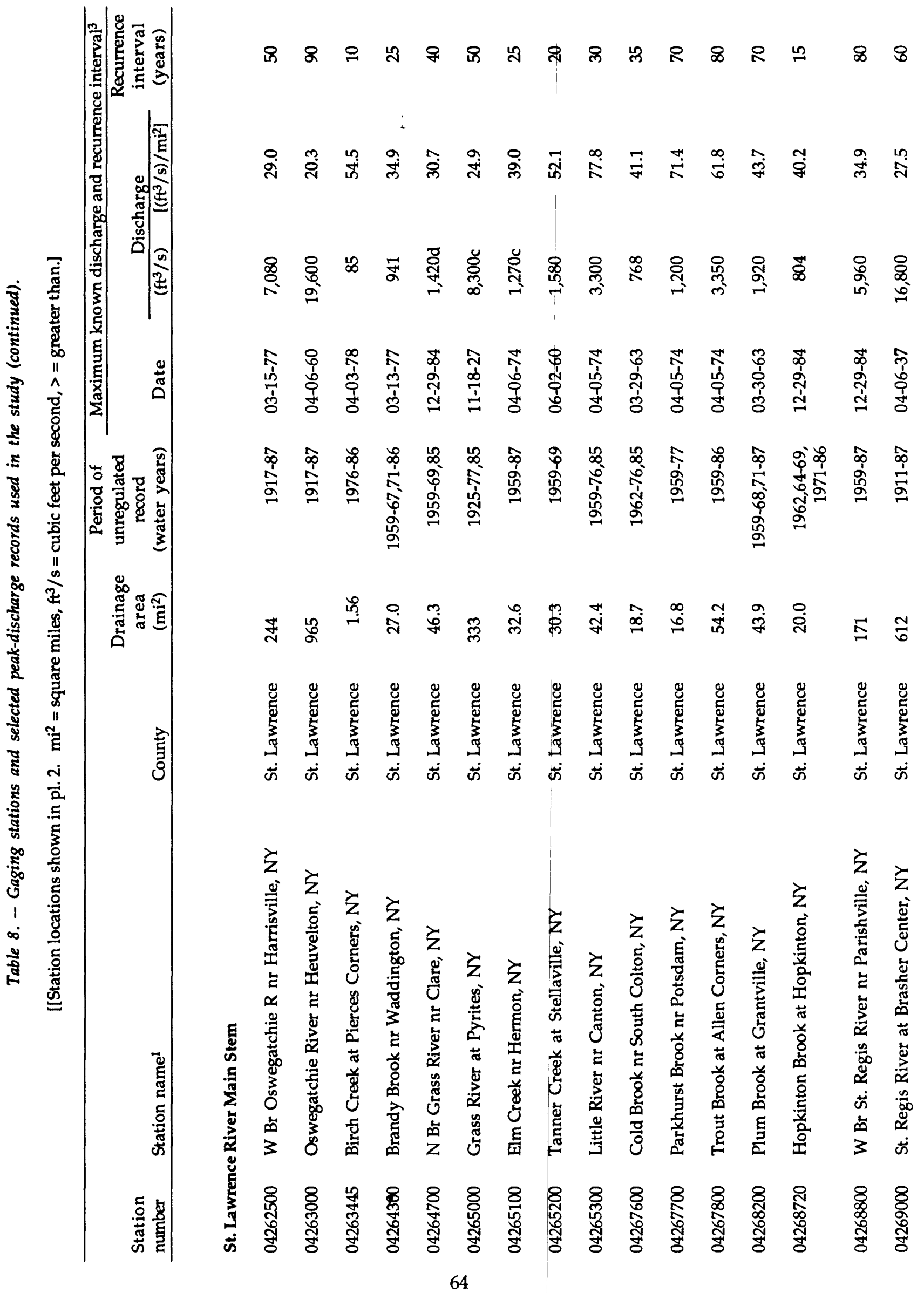




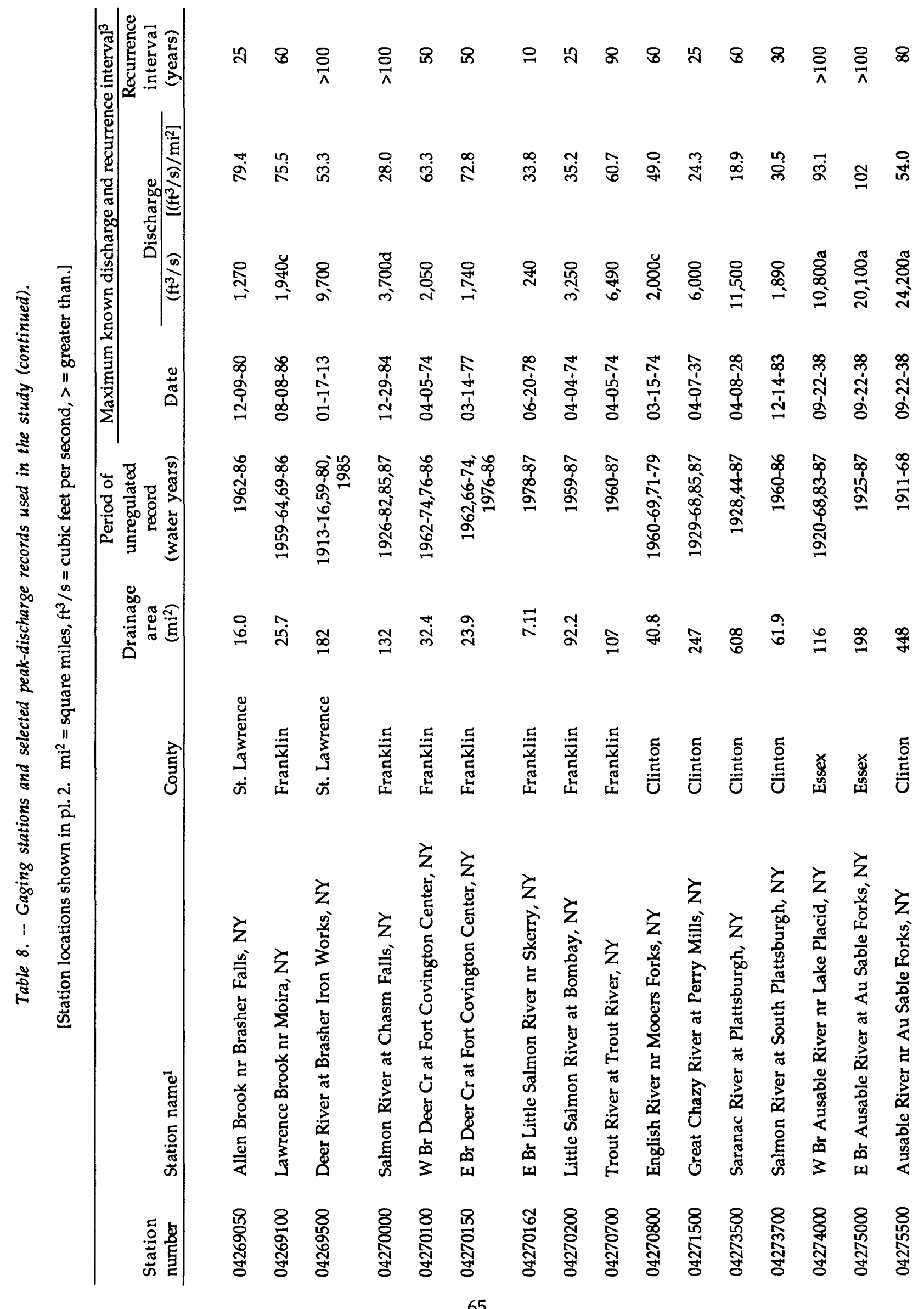




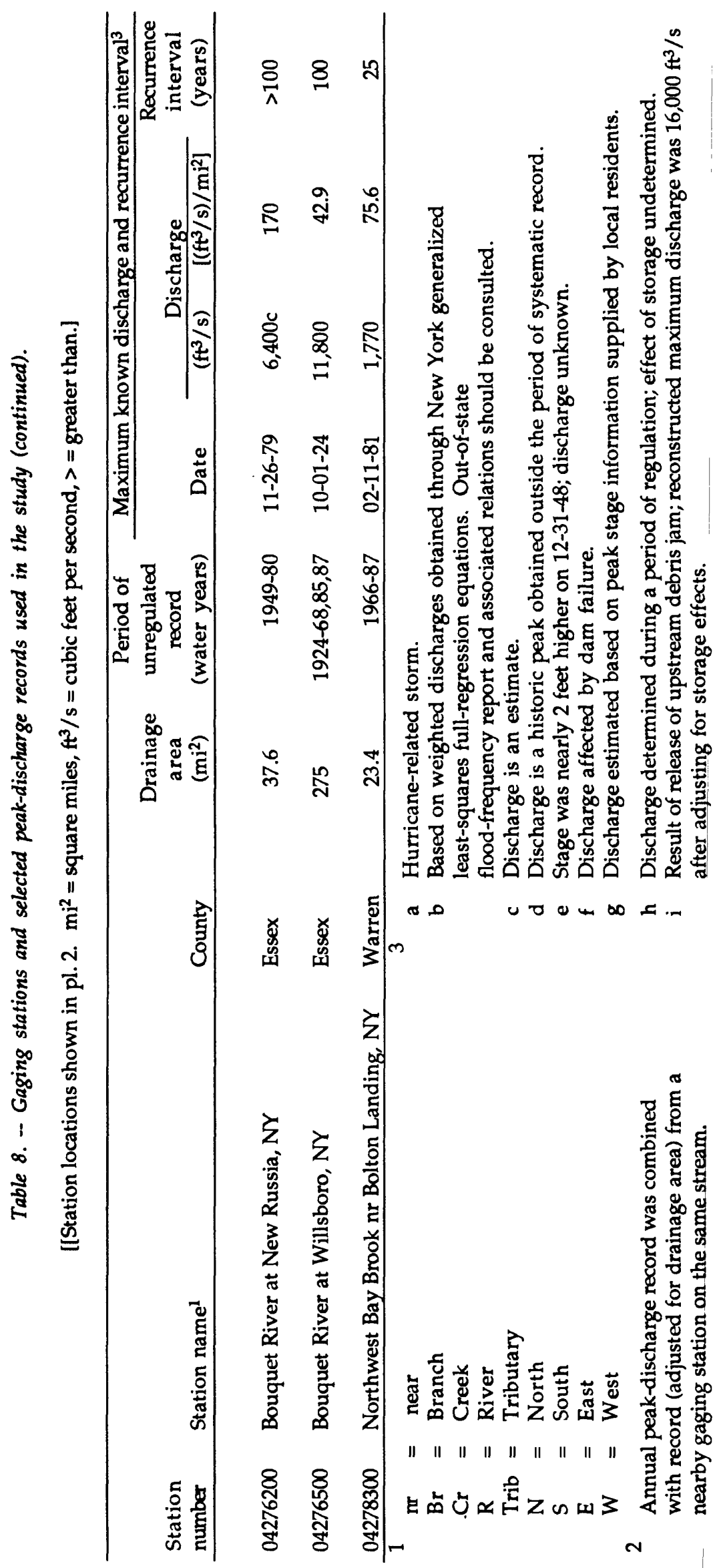


Table 9. --Selected flood characteristics for gaging stations used in the study. 


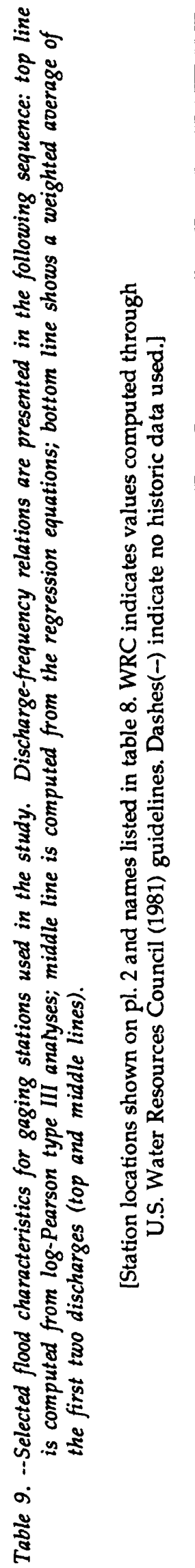

\begin{tabular}{|c|c|c|c|c|c|}
\hline ले & $\stackrel{\not N}{\sim}$ & $\vec{\lambda}$ & $:$ & : & : \\
\hline $\mathscr{1}$ & $\stackrel{2}{2}$ & 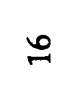 & $\approx$ & in & $\stackrel{20}{\sim}$ \\
\hline 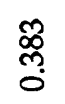 & \& & : & รี & 帛 & :ొ \\
\hline స్ర & $\stackrel{\mathscr{g}}{\rightarrow}$ & $\stackrel{\infty}{=}$ & శ̊ & $\stackrel{\leftrightarrow}{9}$ & 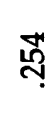 \\
\hline ळి & 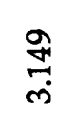 & 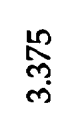 & $\stackrel{\text { సี }}{ }$ & 惫 & 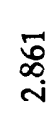 \\
\hline$\overbrace{0}^{0,0}$ & $\hat{\sigma}$ & $\hat{\theta}$ & ֶֻ. & क़ & $\tilde{\xi}$ \\
\hline ़్ְ & 웅 & $\stackrel{\infty}{\longrightarrow}$ & ণ़ণ & \&્̣ & 菾 \\
\hline & $\stackrel{\infty}{-\infty}$ & 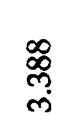 & $\stackrel{\text { స్ }}{\text {. }}$ & 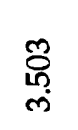 & $\overrightarrow{\stackrel{s}{S}}$ \\
\hline
\end{tabular}

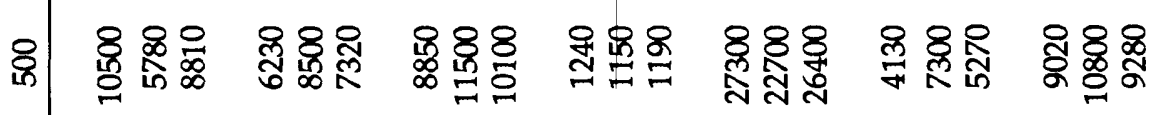

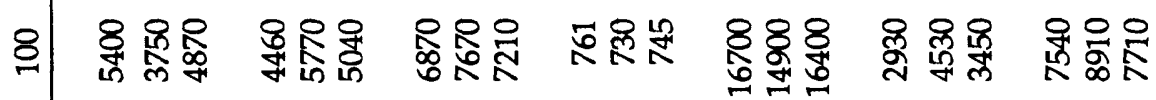

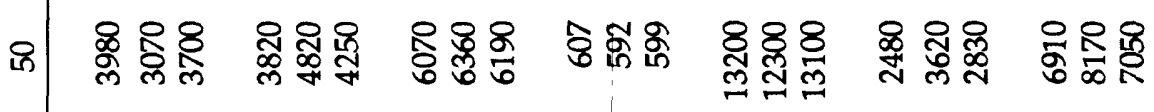

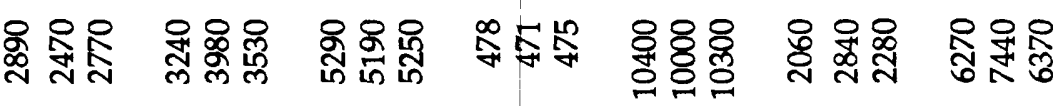

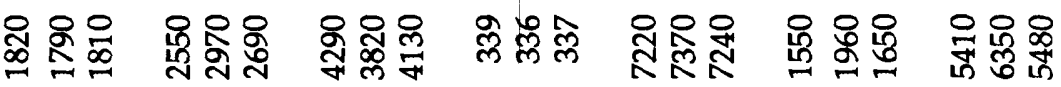

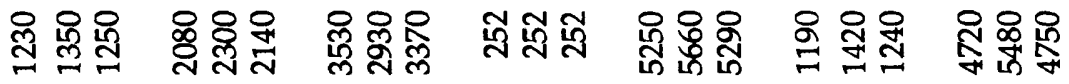

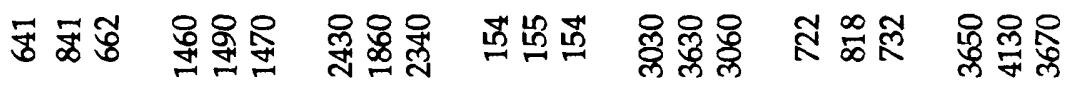

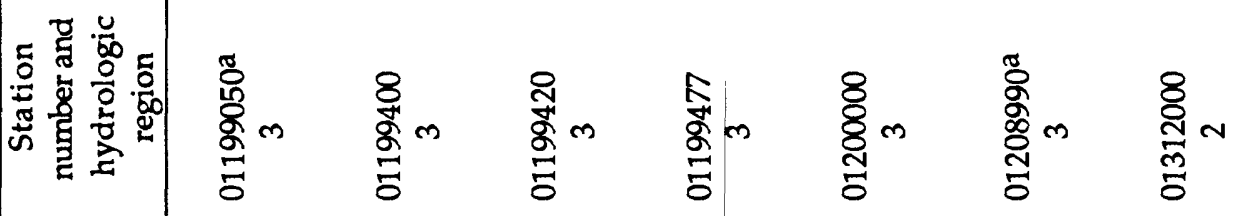




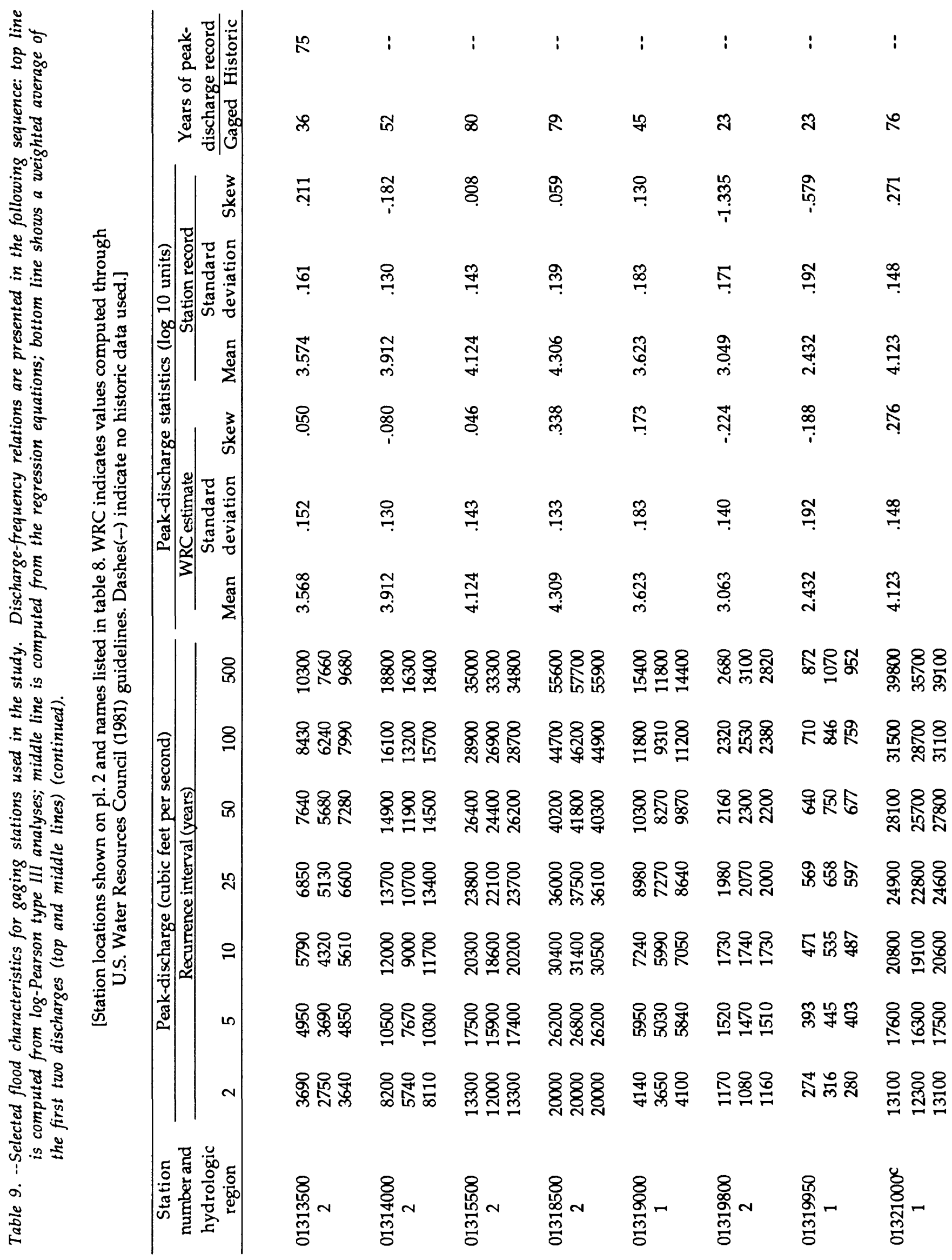




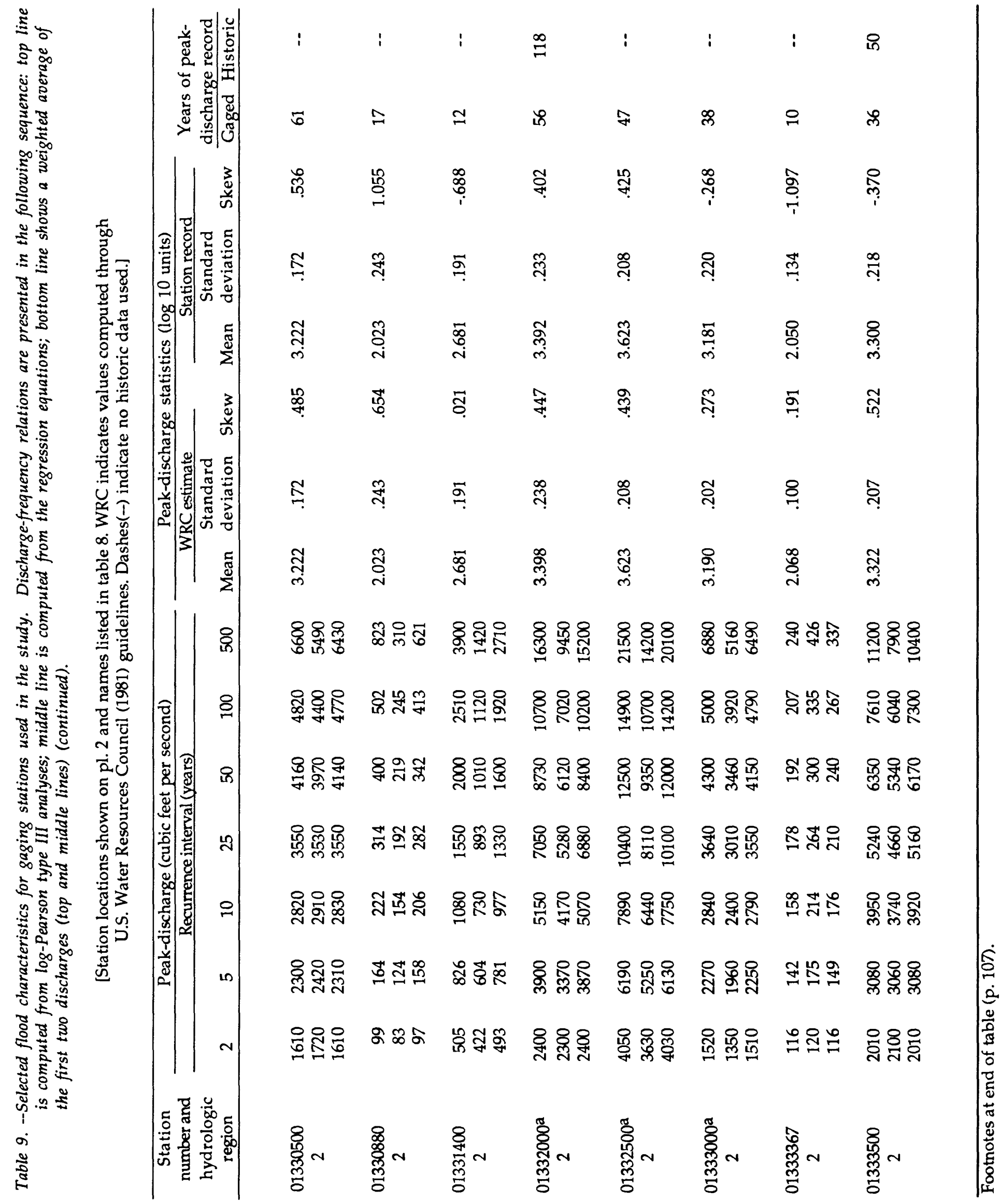




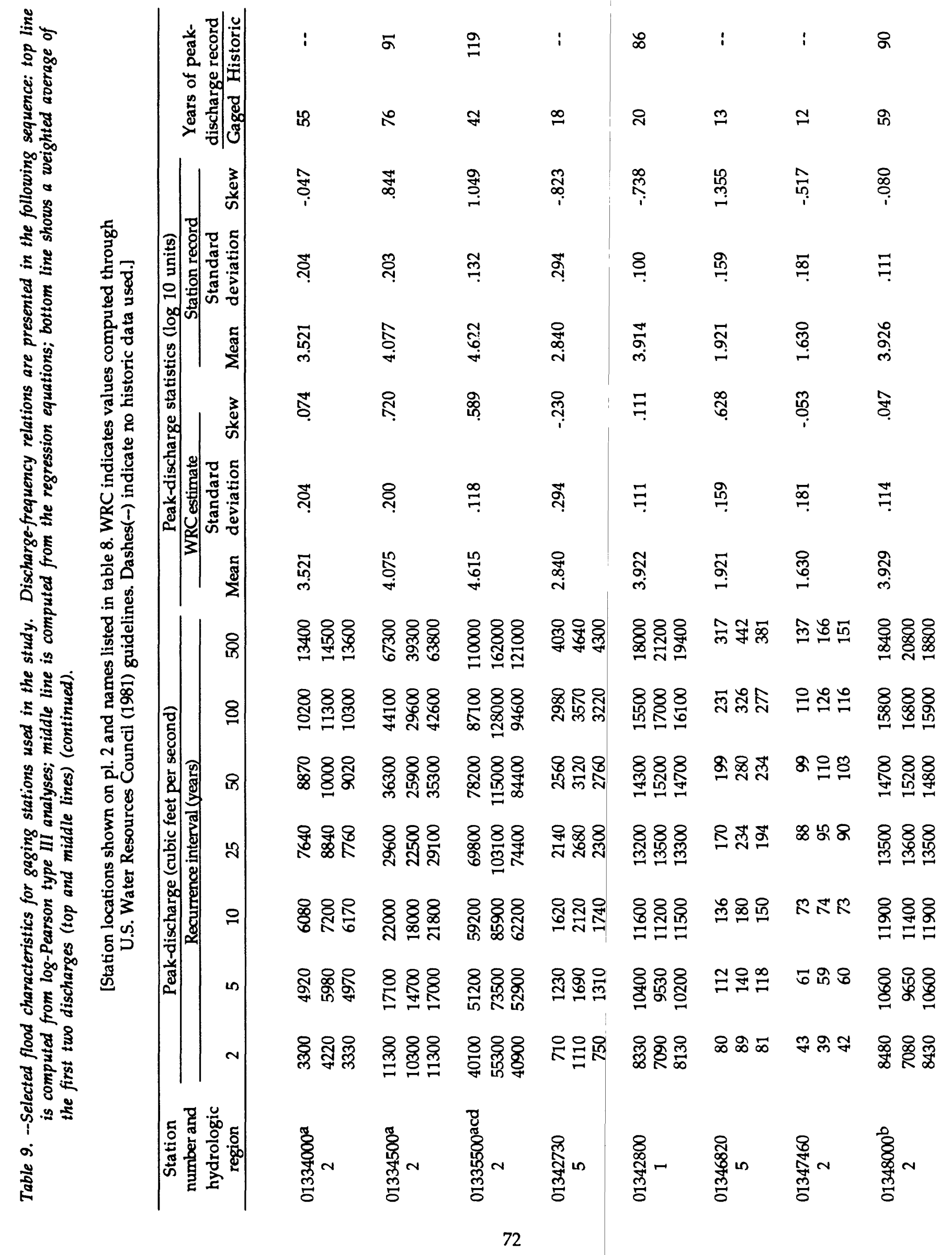




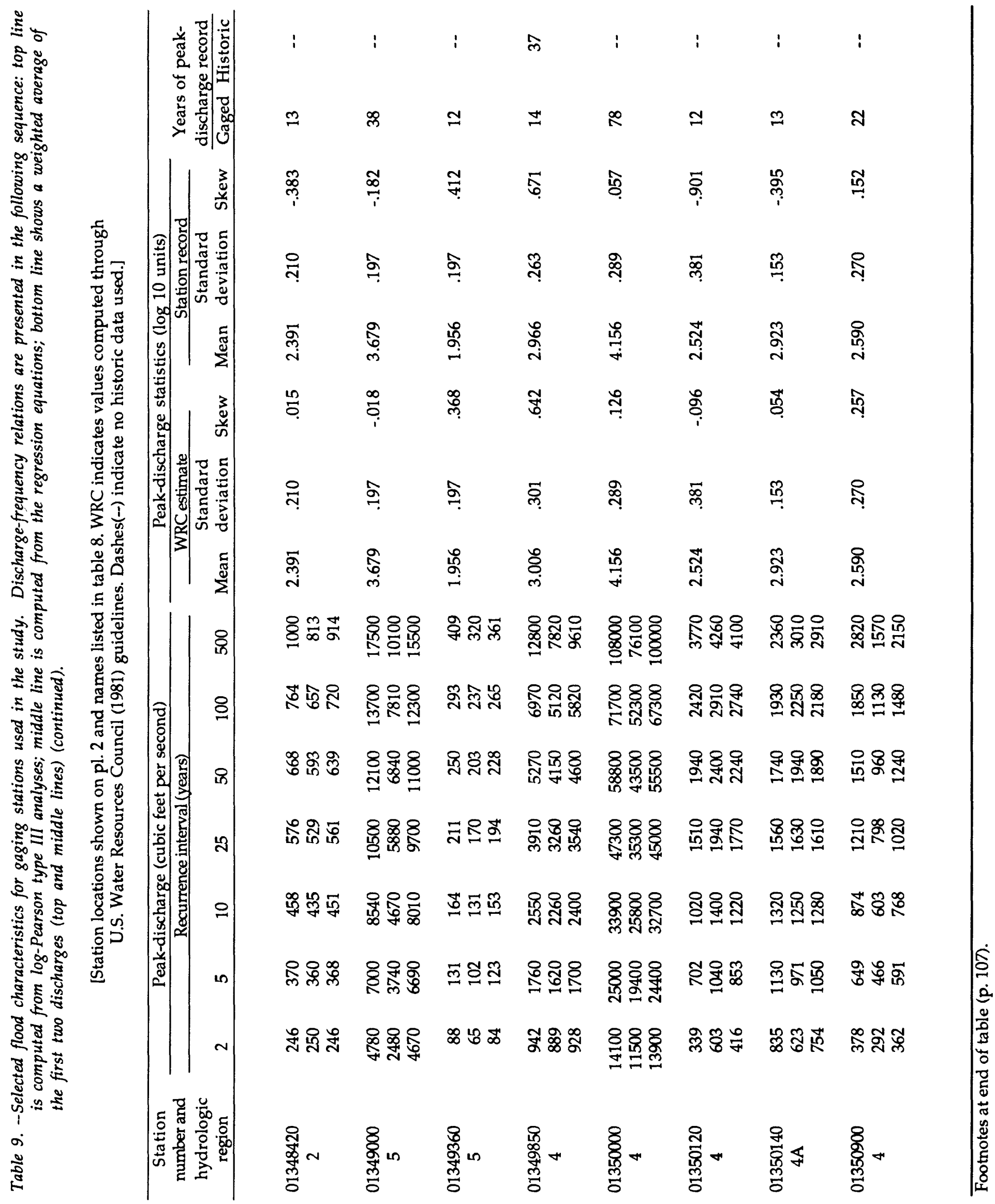



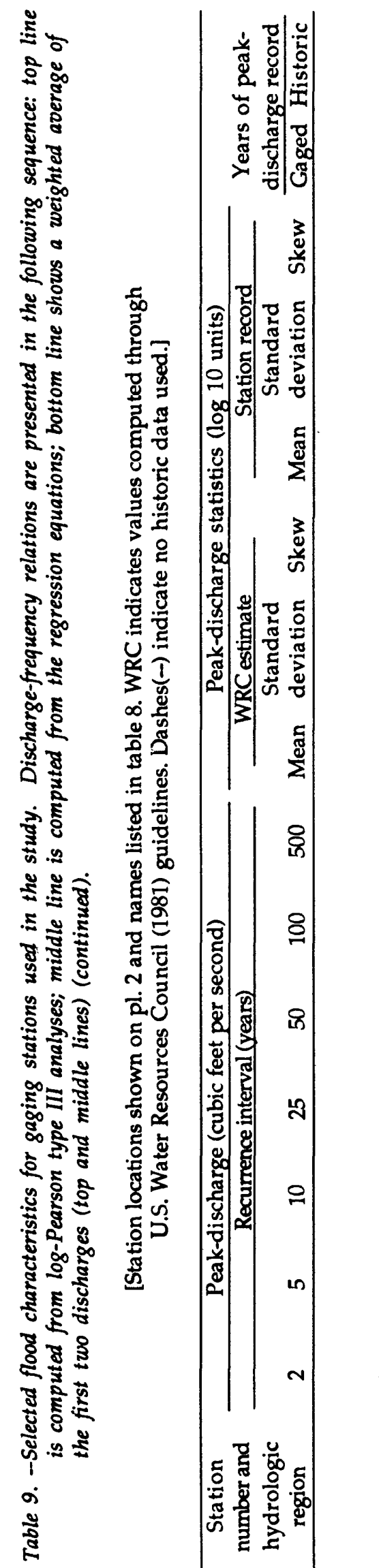

\begin{tabular}{|c|c|c|c|c|c|}
\hline : & i & $\stackrel{10}{2}$ & g్ & $:$ & i \\
\hline$\stackrel{2}{2}$ & $\approx$ & $\mathscr{7}$ & $\stackrel{\infty}{\sim}$ & ని & 우 \\
\hline ஸึ & $\underset{F}{F}$ & రి & $\stackrel{\infty}{\underset{ }{~}}$ & $\stackrel{\infty}{\stackrel{\infty}{\rightarrow}}$ & $\stackrel{2}{\stackrel{2}{?}}$ \\
\hline
\end{tabular}

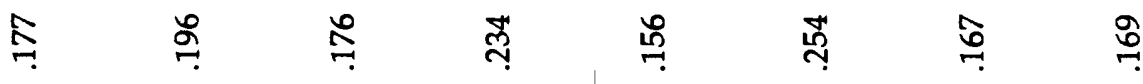

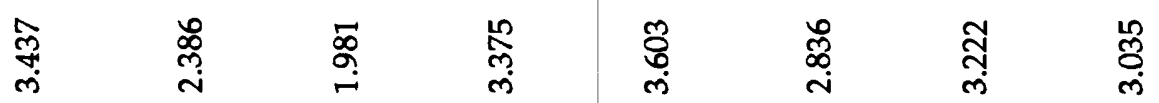

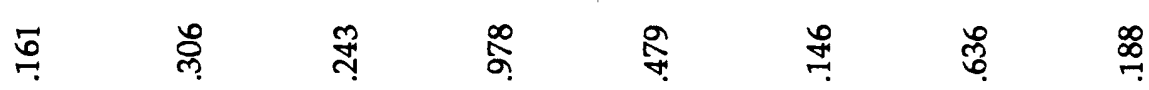

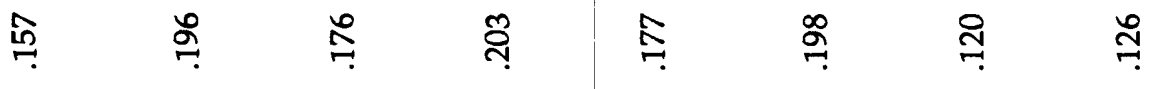

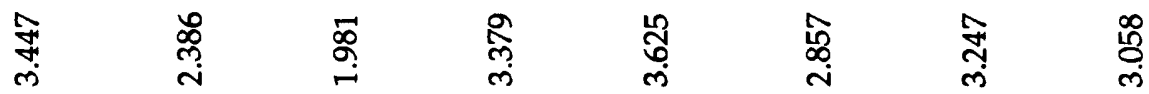

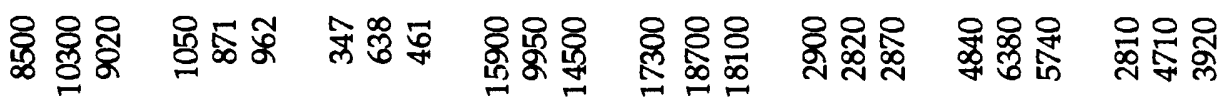

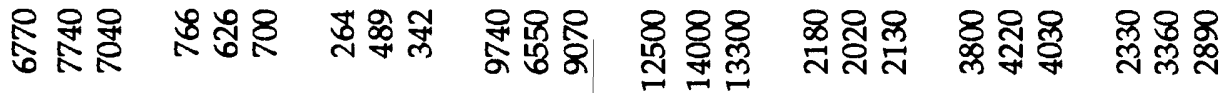

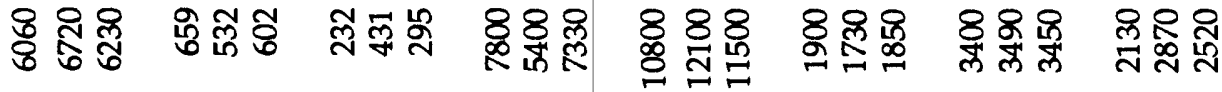

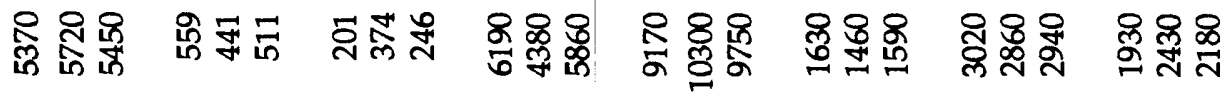

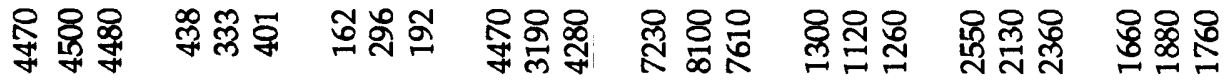

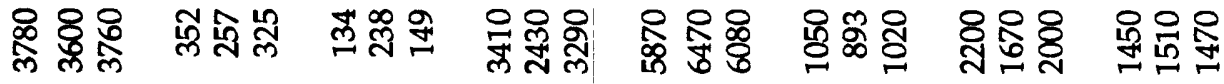

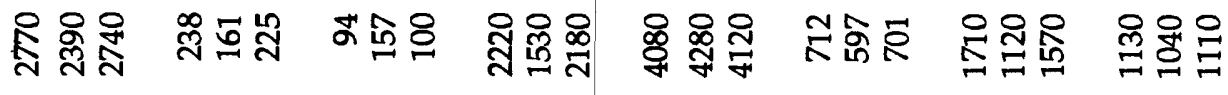

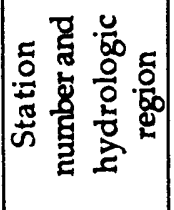

总

鰙

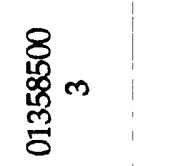

各

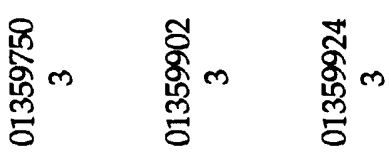



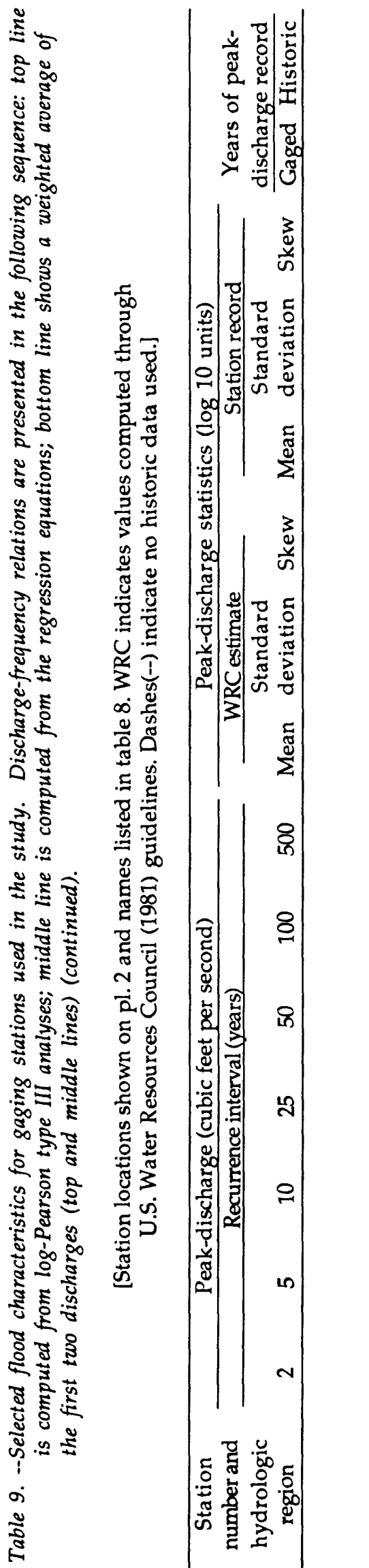

\begin{tabular}{|c|c|c|c|c|c|}
\hline$i$ & 满 & $\infty$ & ले & i & i \\
\hline 유 & $\stackrel{2}{7}$ & $\not 8$ & $\Xi$ & $\mathbb{N}$ & ని \\
\hline જี & ల్రై & $\stackrel{\infty}{8}$ & $\underset{i}{i}$ & $\stackrel{P}{7}$ & $\underset{i}{\mathbb{O}}$ \\
\hline
\end{tabular}

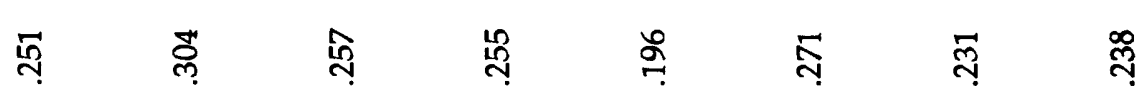

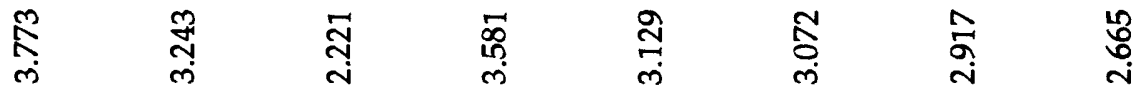

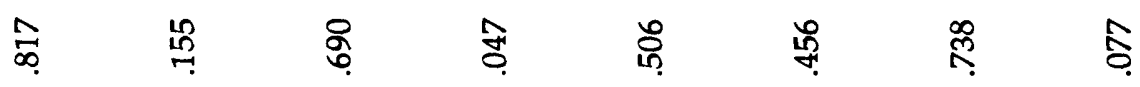

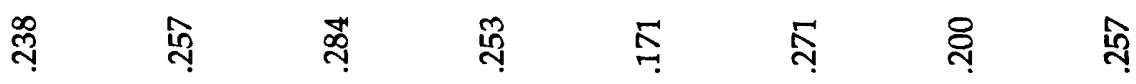

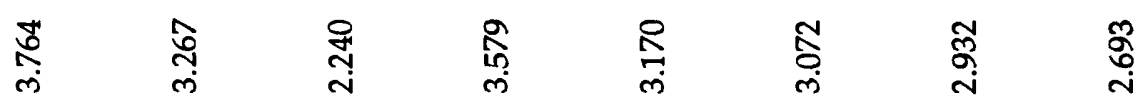

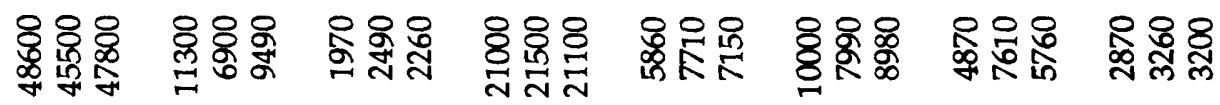

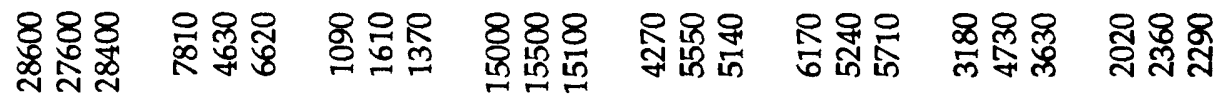

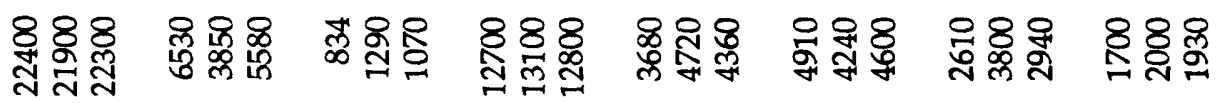

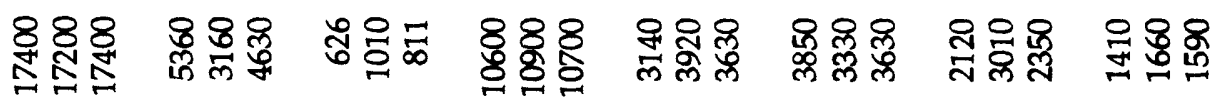

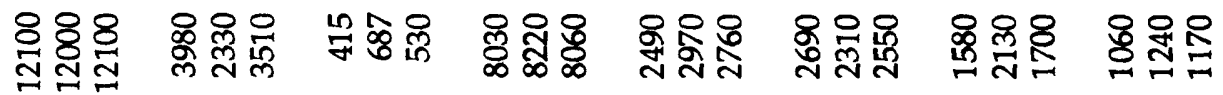

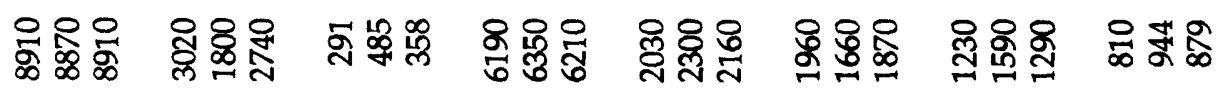

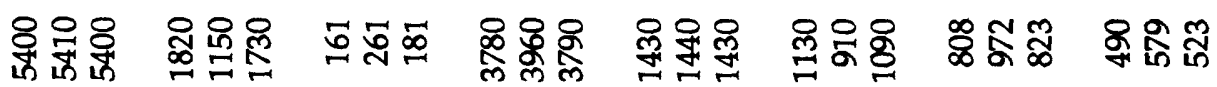

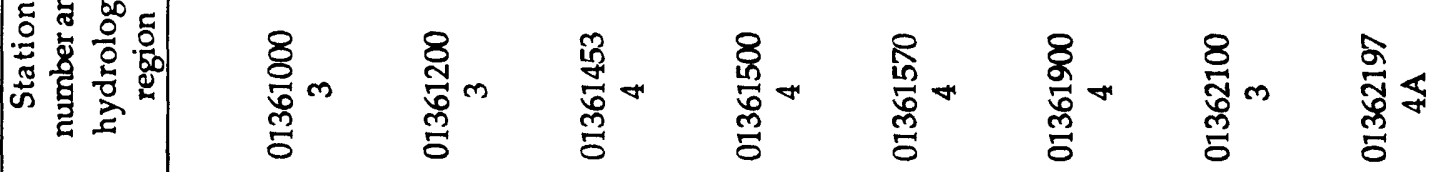




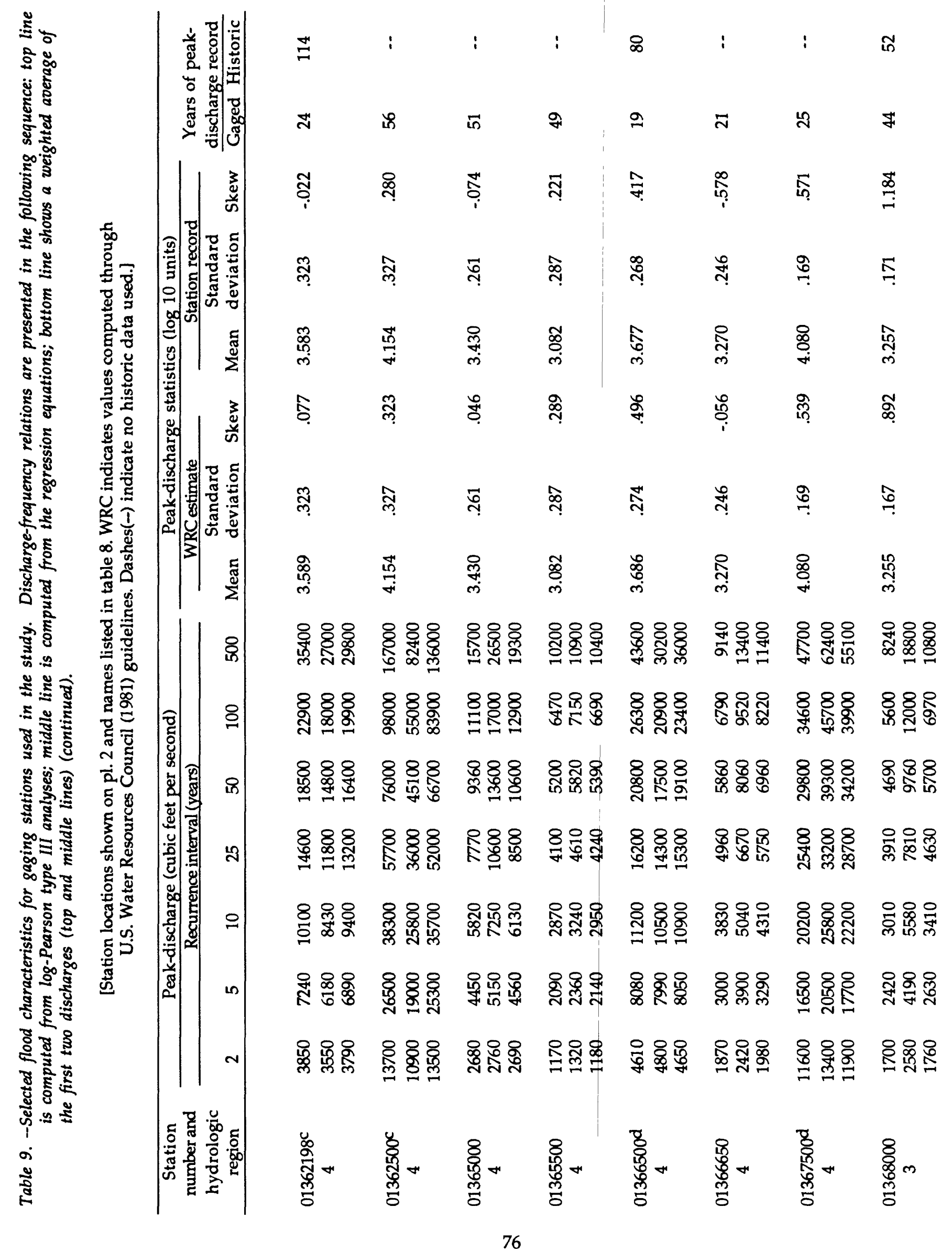




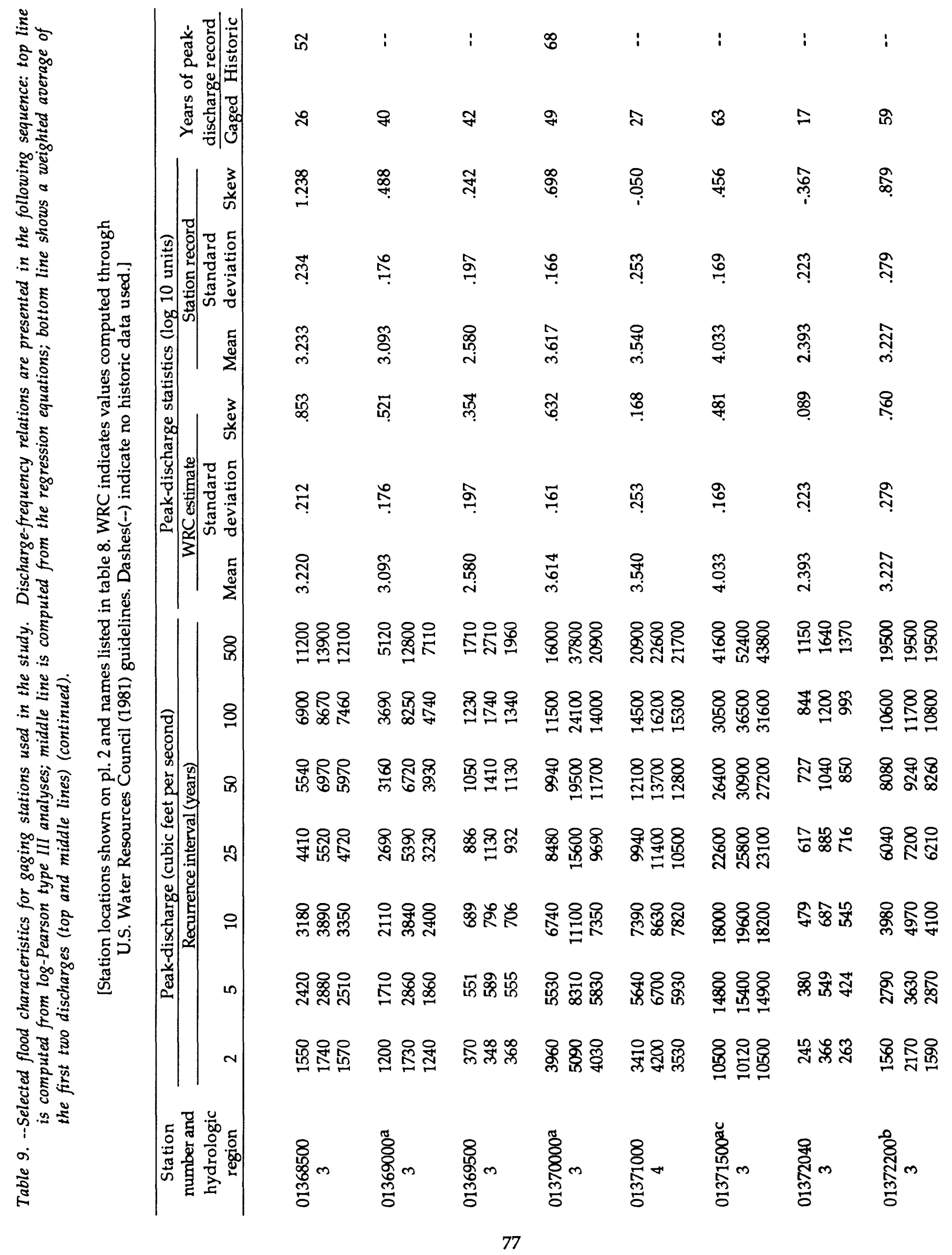




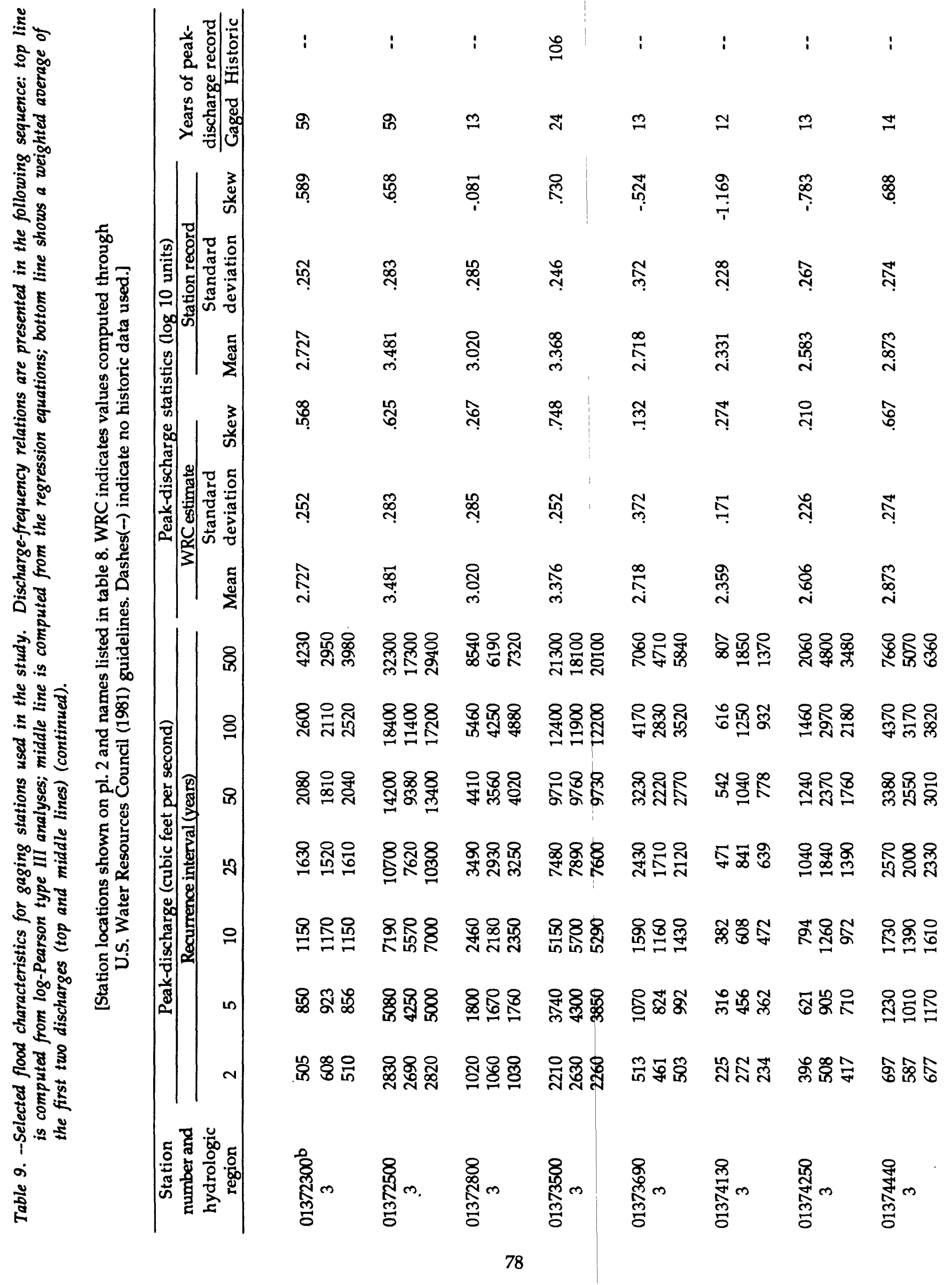




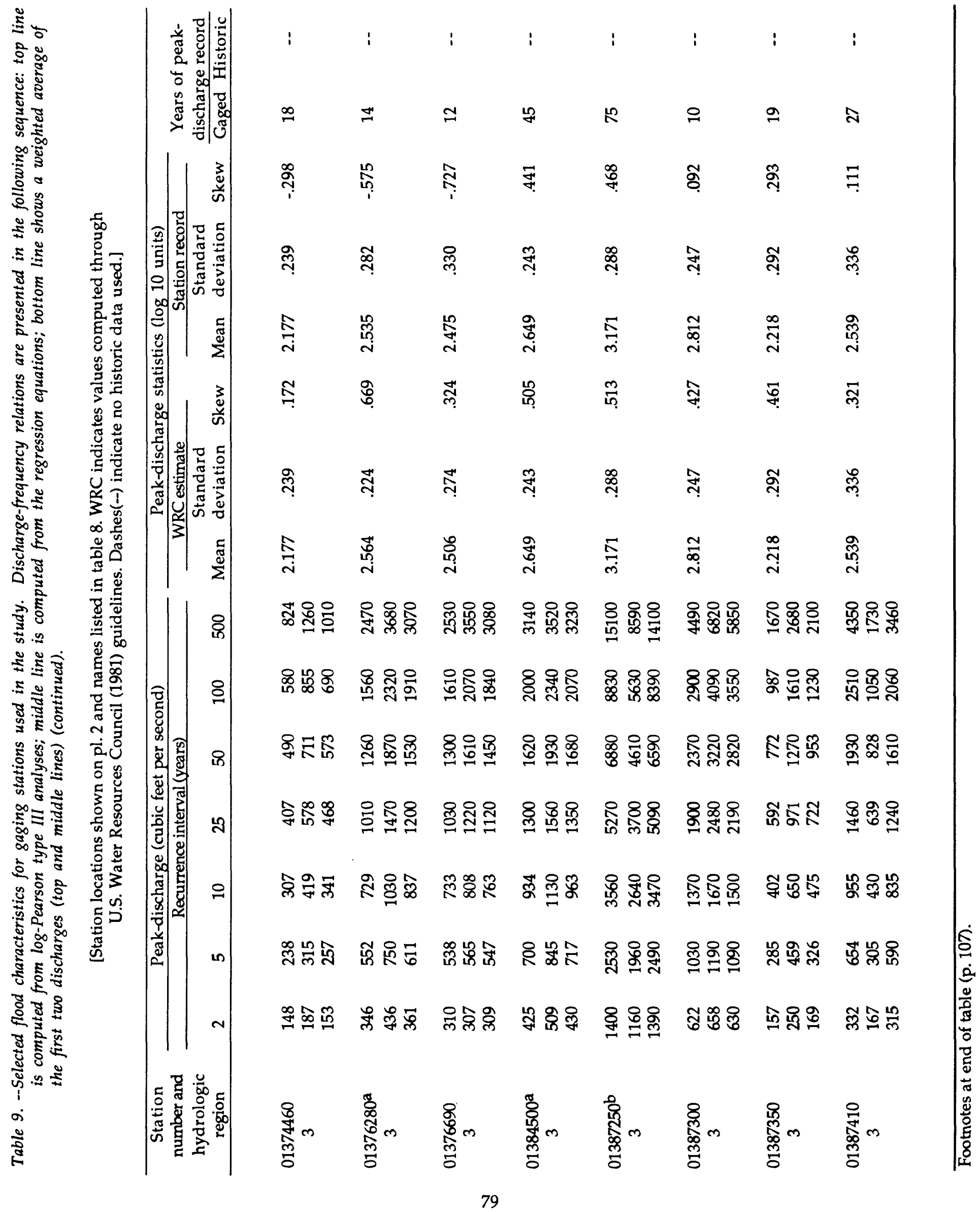




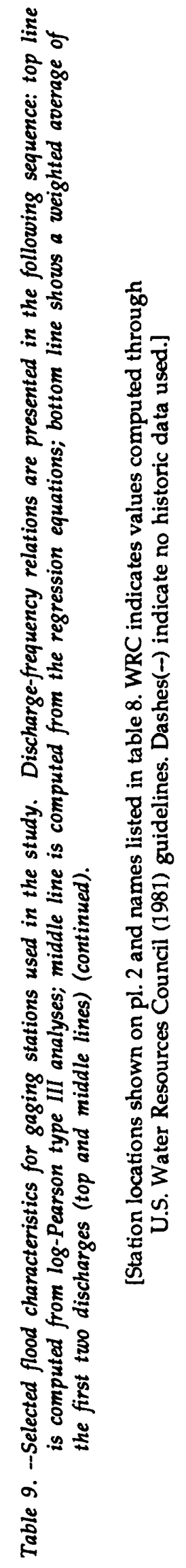

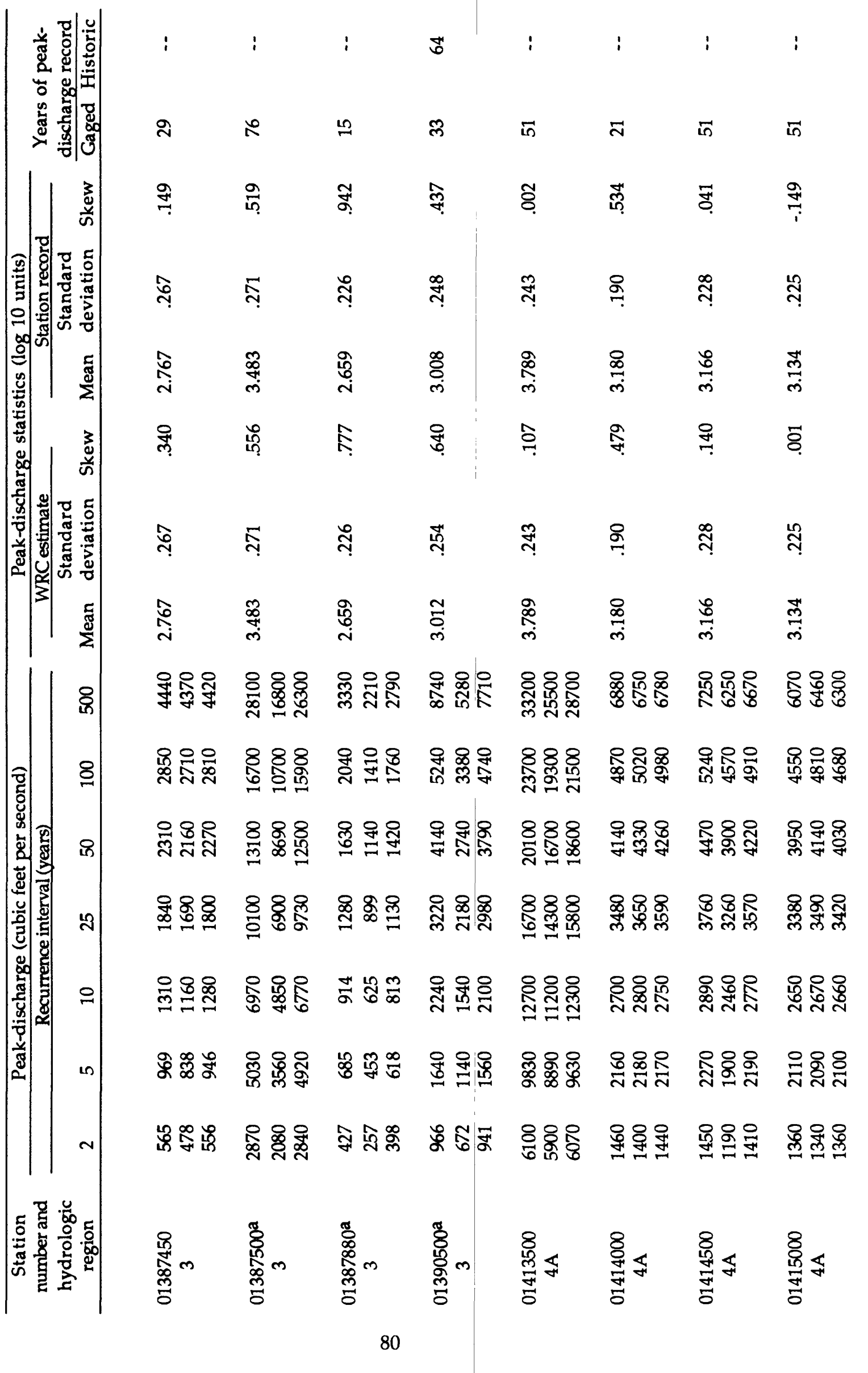




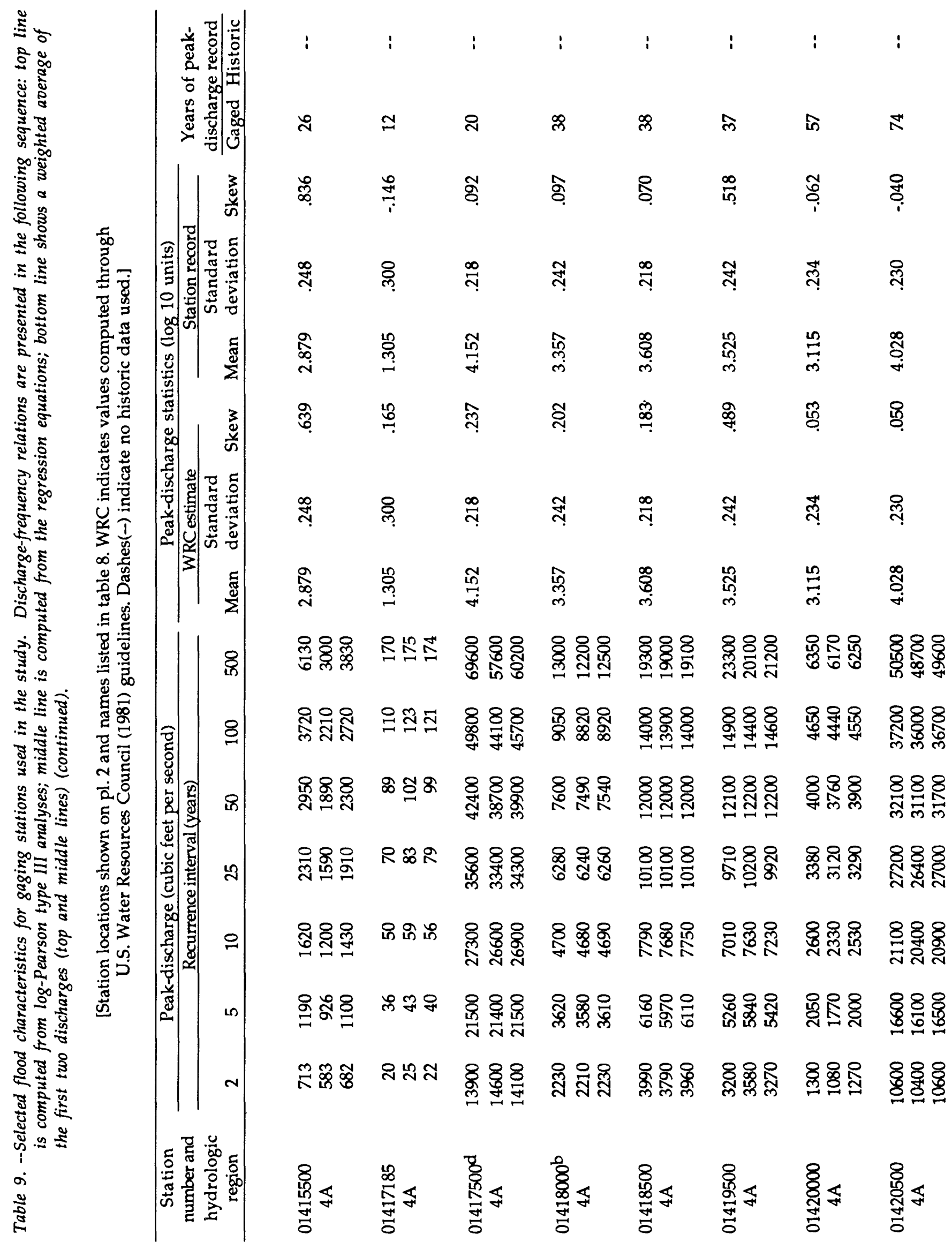




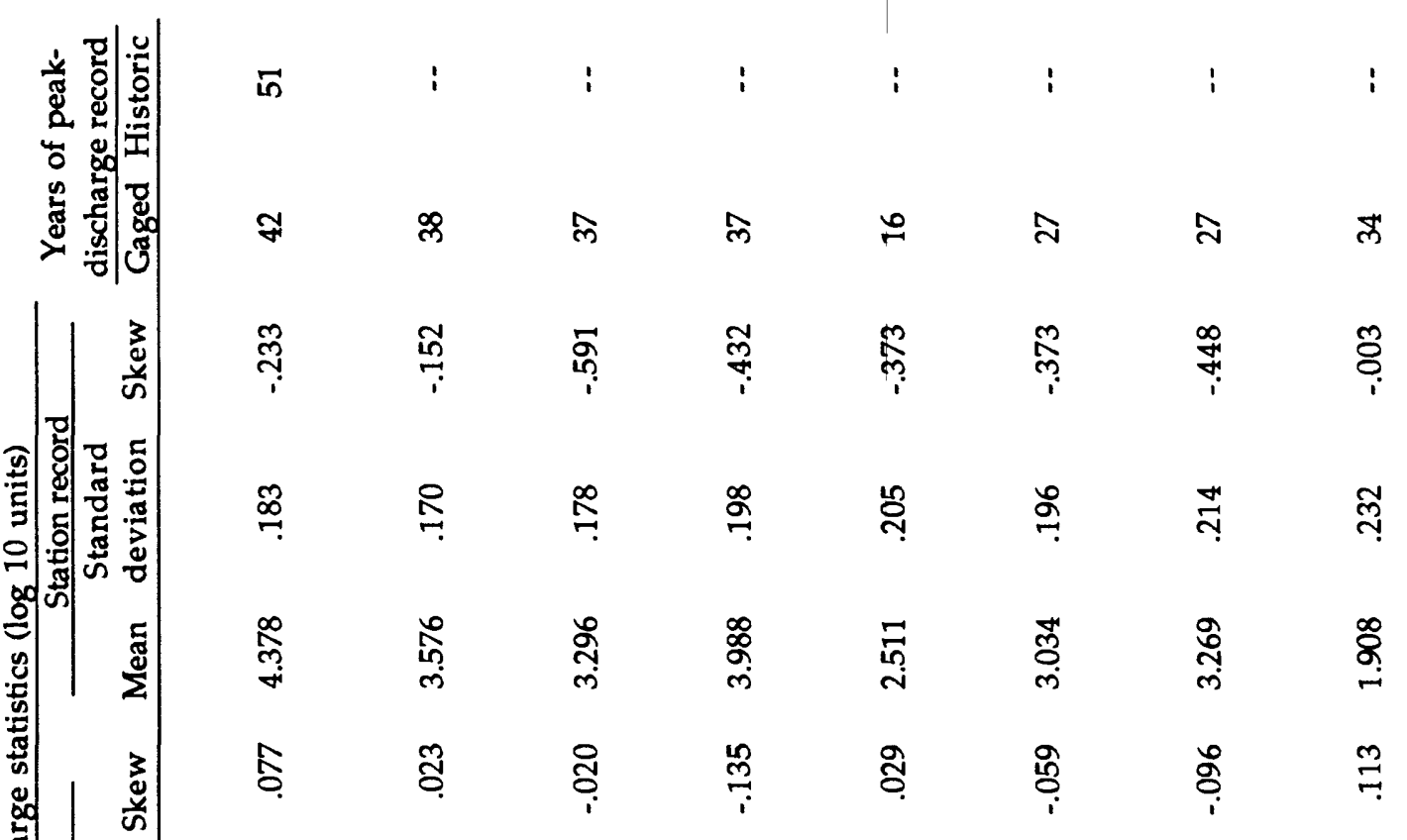

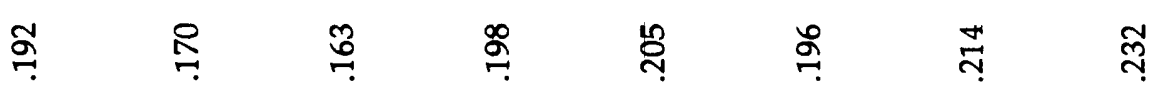

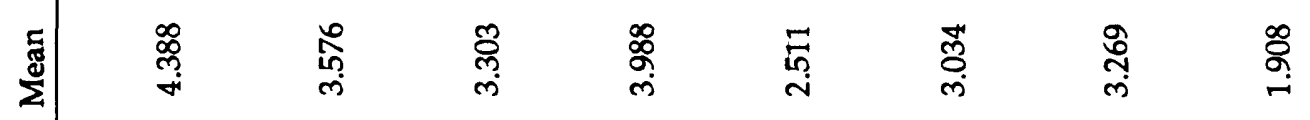

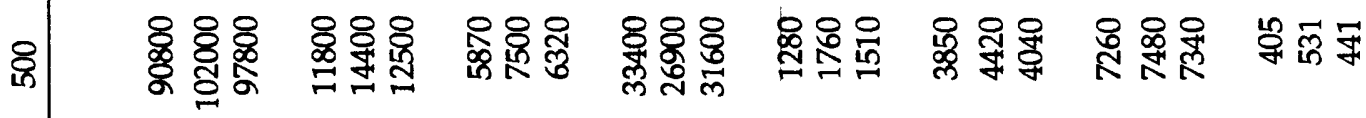

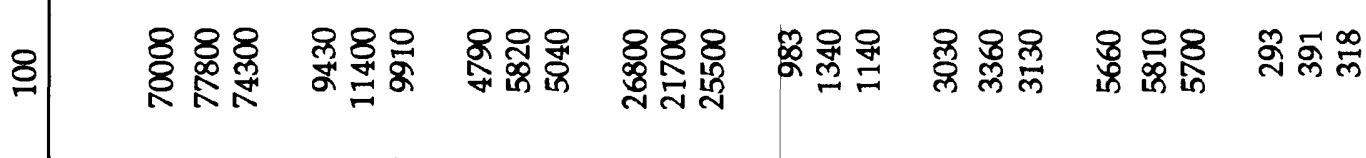
б̆

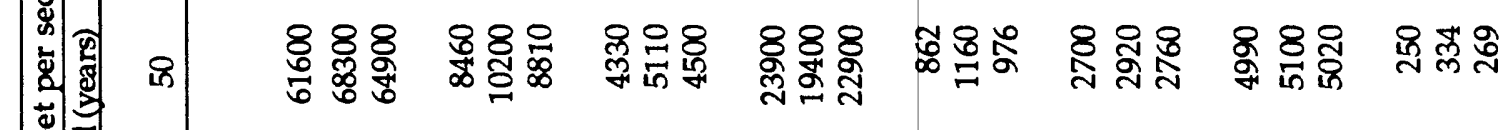

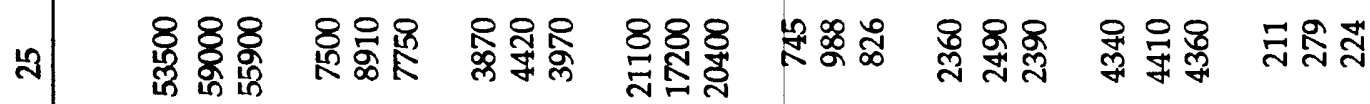
尊密

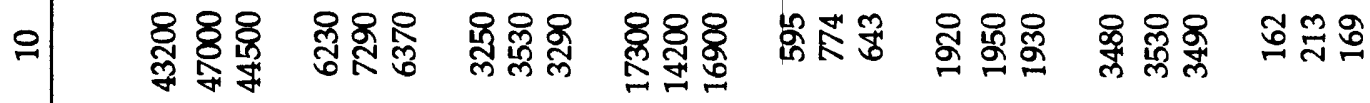

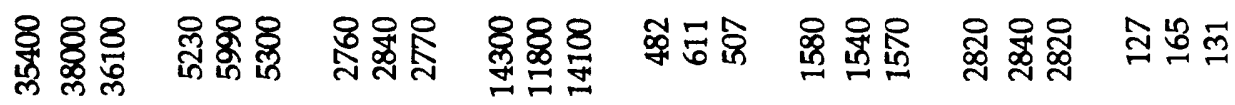

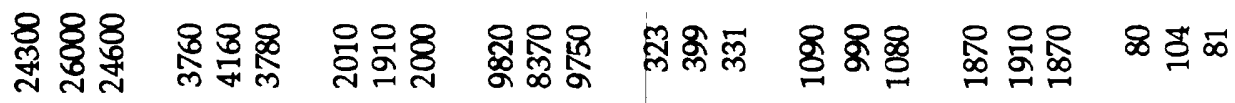

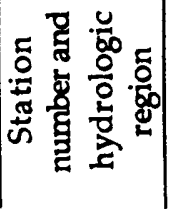

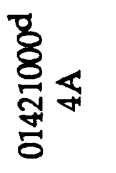

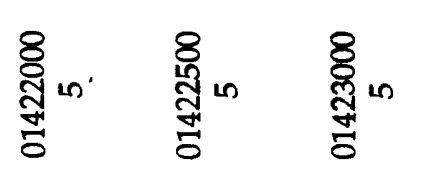

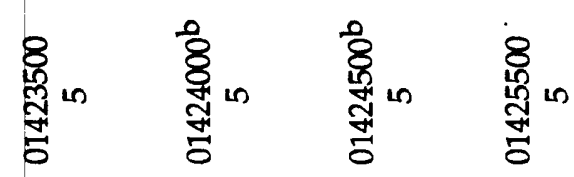




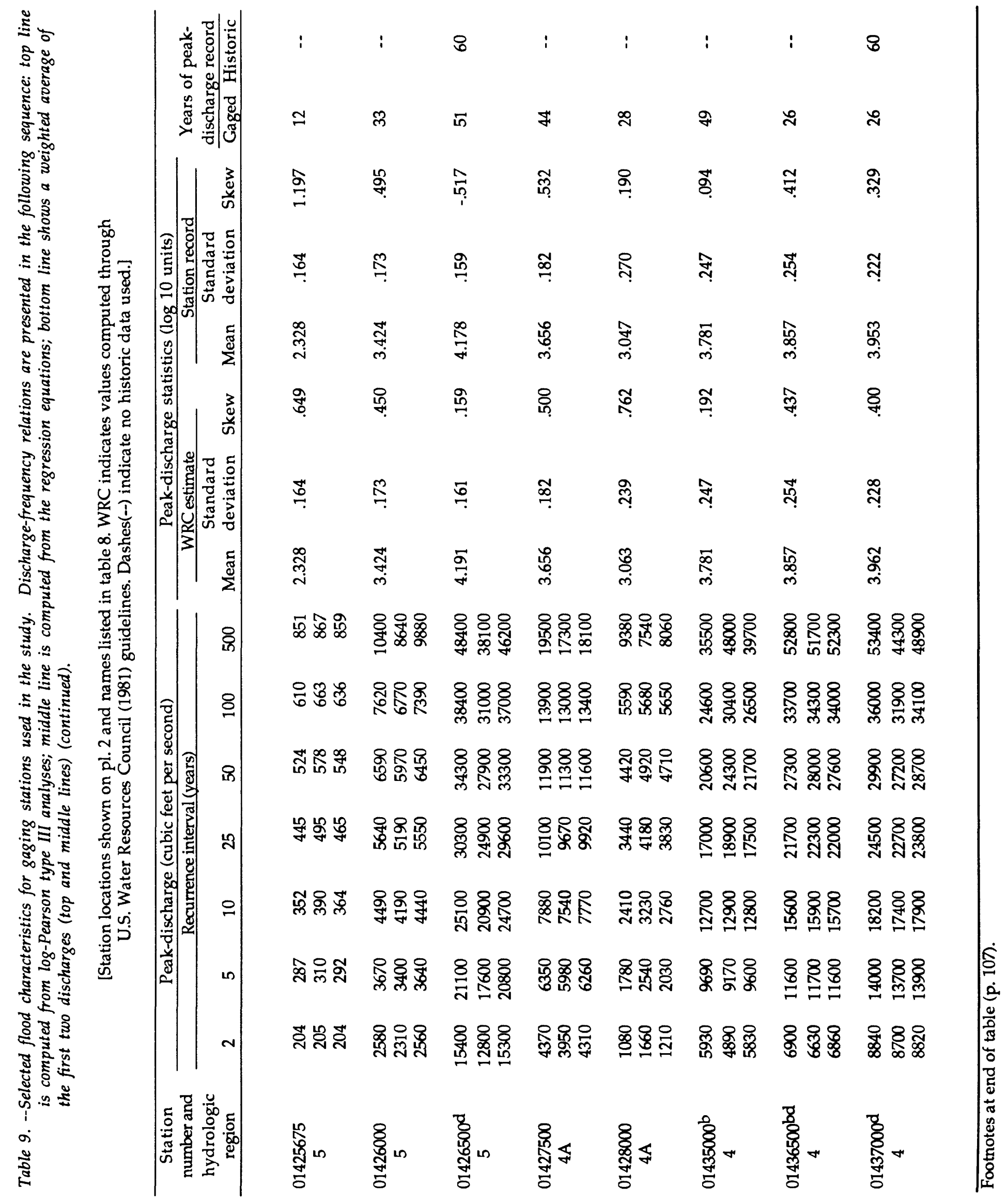



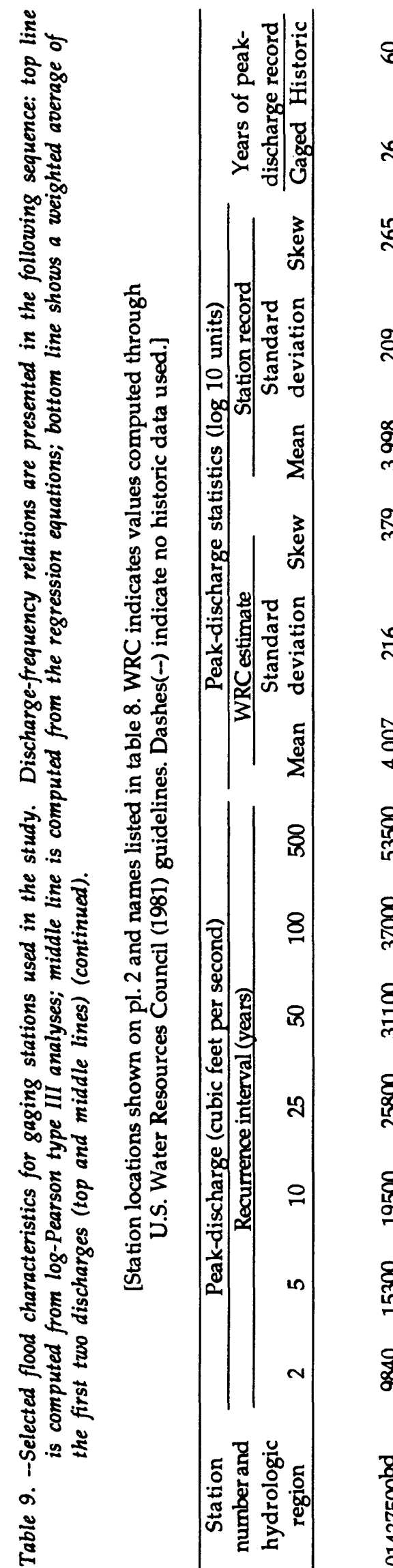

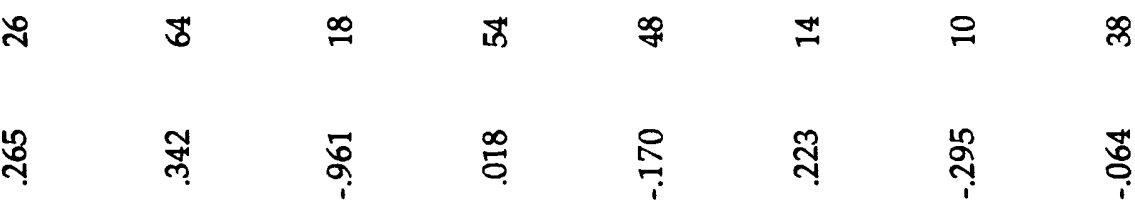

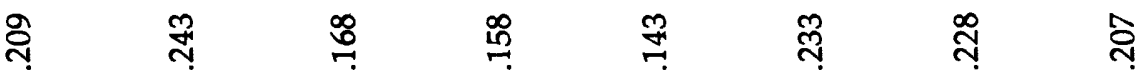

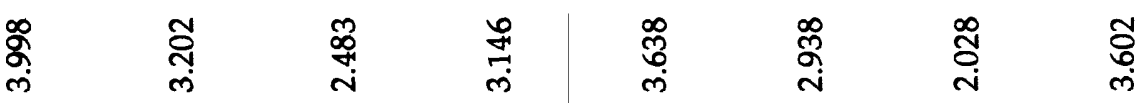

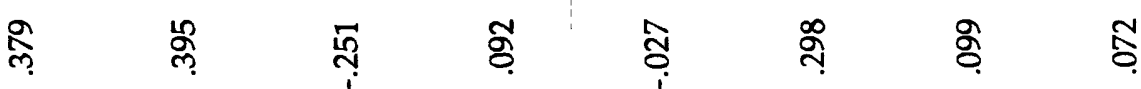

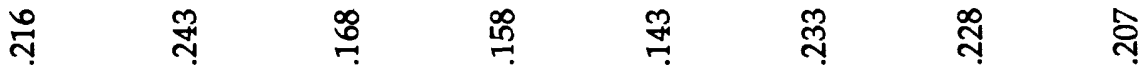

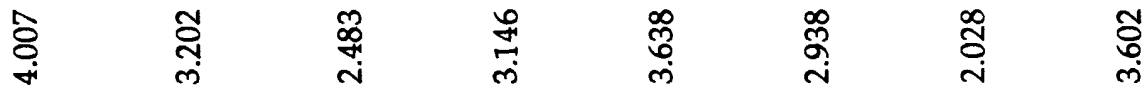

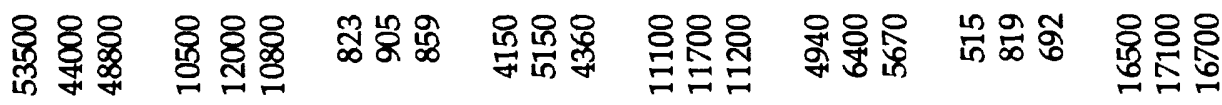

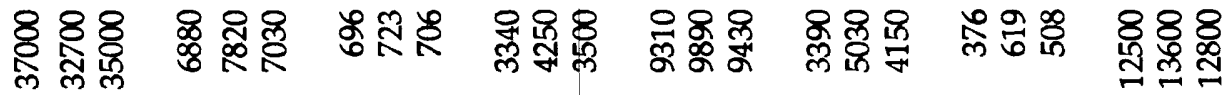

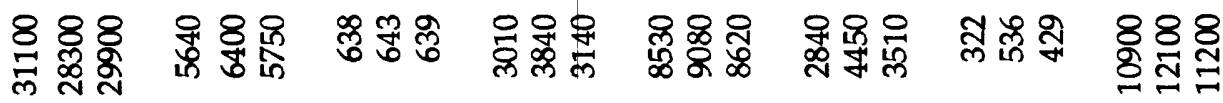

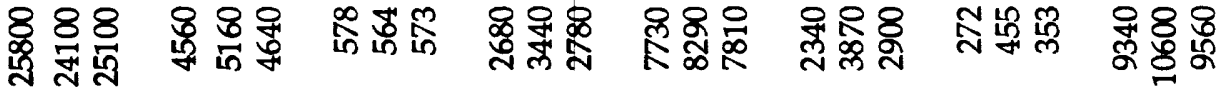

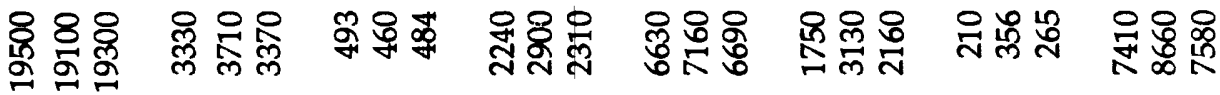

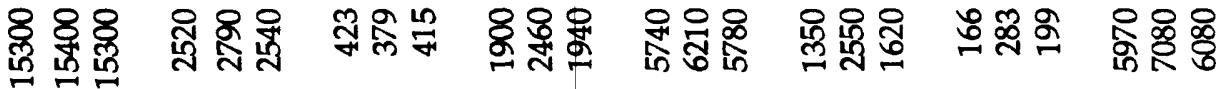

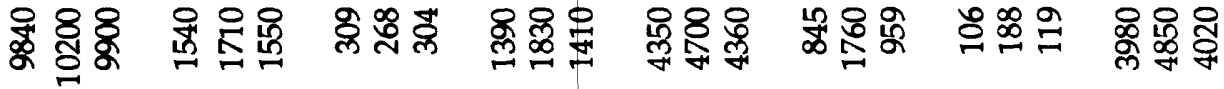

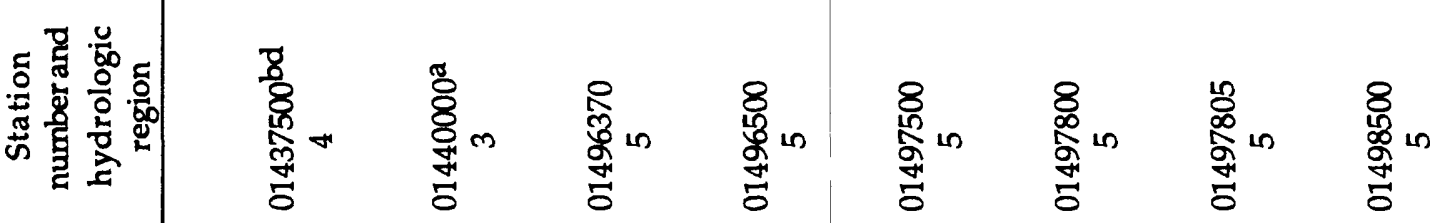



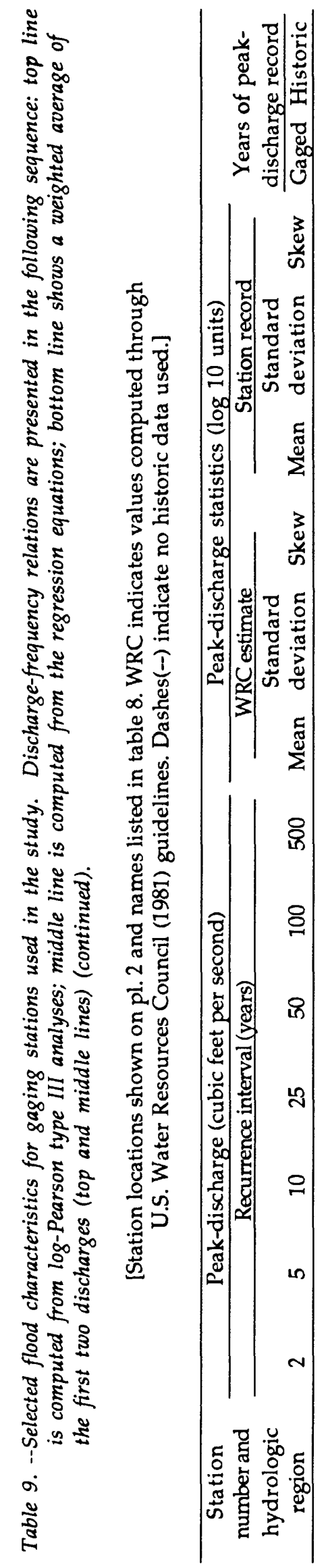

$\stackrel{i}{\stackrel{1}{2}}$

$\stackrel{10}{7 !}$

$\stackrel{2}{2}$

ㄱำ

ఫ్లి

ํㅜㄱ

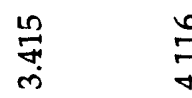

i̊n

กำ

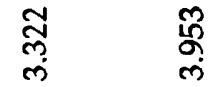

8

ถ⿱

F

\&

กิ



$\stackrel{\Xi}{\because}$

$\stackrel{2}{9}$

g

$\stackrel{?}{?}$

ఫ্ল

$\stackrel{\circ}{7}$ ํㅜㄴ

学

i্

$\stackrel{\infty}{\stackrel{m}{\rightarrow}} \quad \stackrel{\vec{m}}{\sim}$

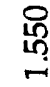

ल्ले : ळ్

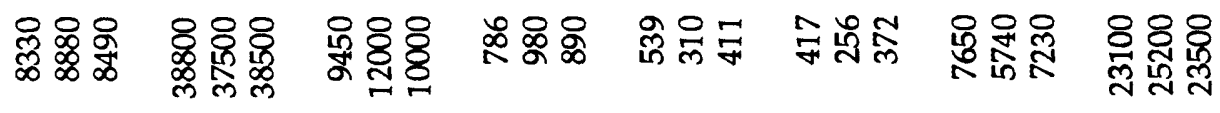

速造

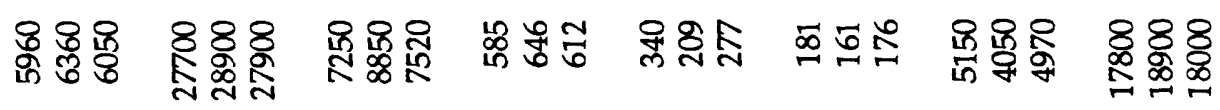

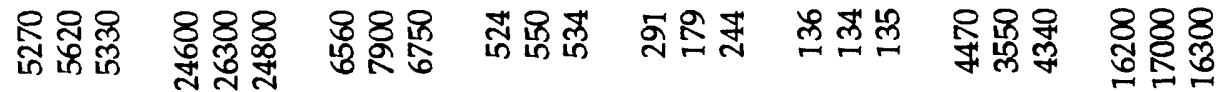

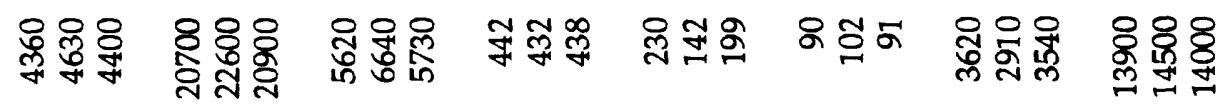

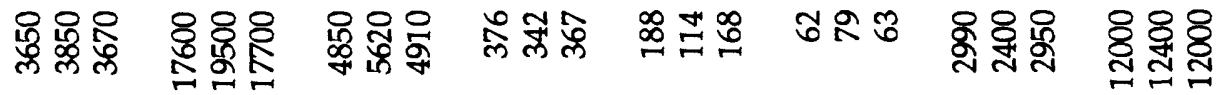

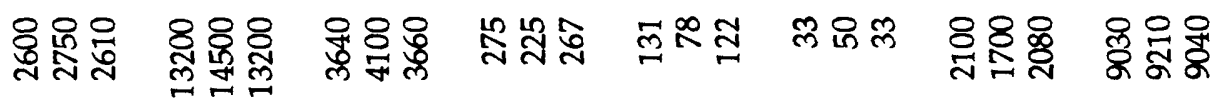

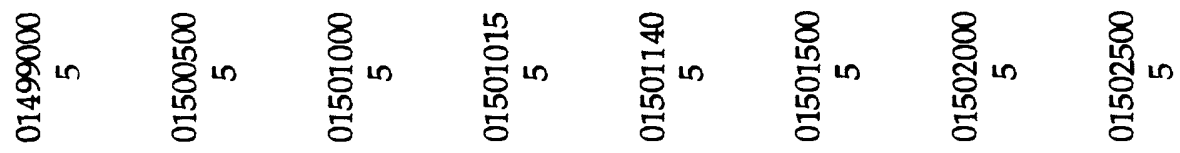


:

$\$$

jె

I

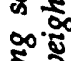

$\frac{2}{2}$

o

3

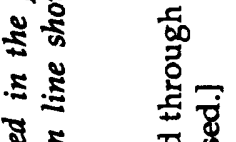

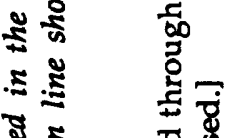

E

蛋

ล.

呬票

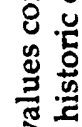

焉

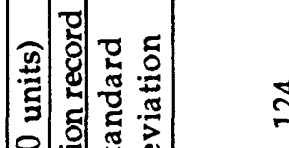

$\stackrel{\Xi}{\varpi}$

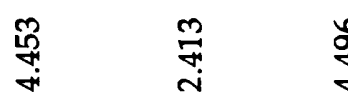

Ðั

ธิ

8)

픔ำ

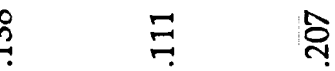

$\stackrel{\infty}{\sim} \stackrel{9}{\square}$

สุ

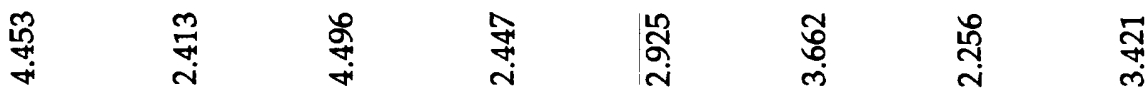

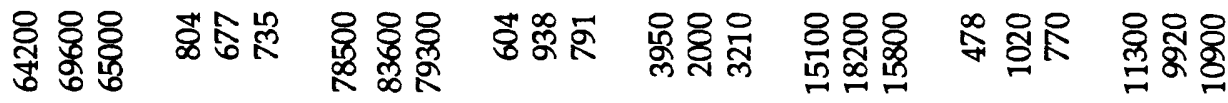

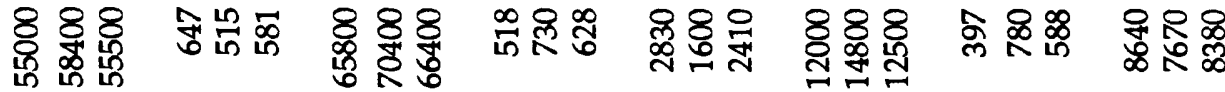

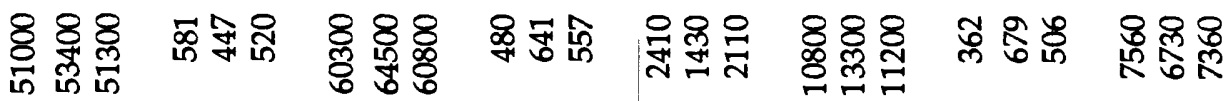

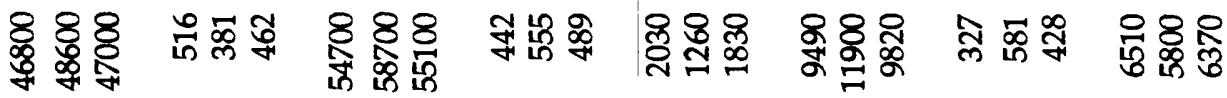

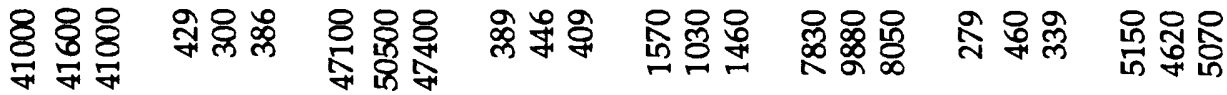

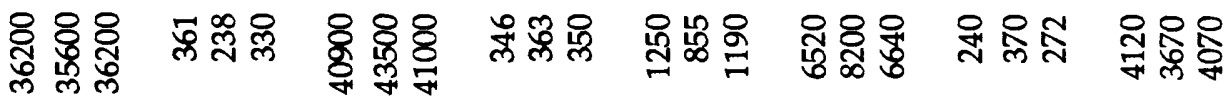

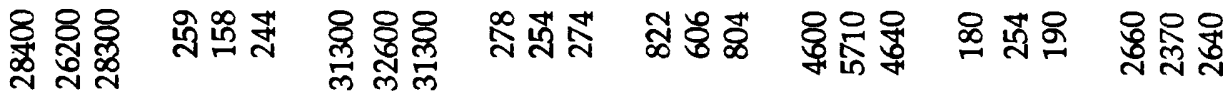

홇

茕

各

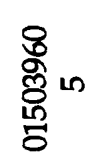

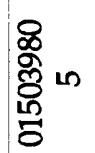

8
80
80
0
0

응

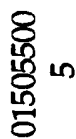




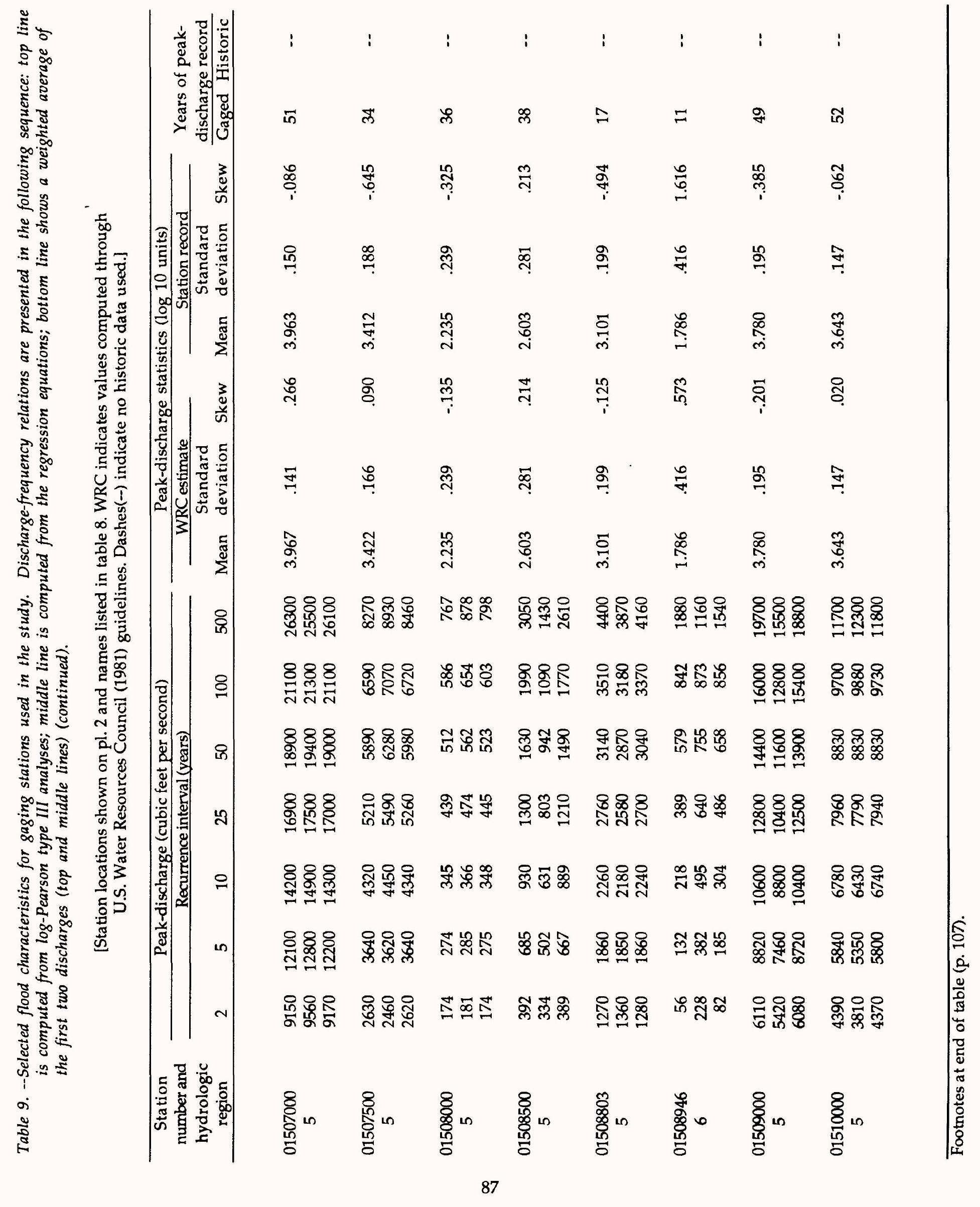




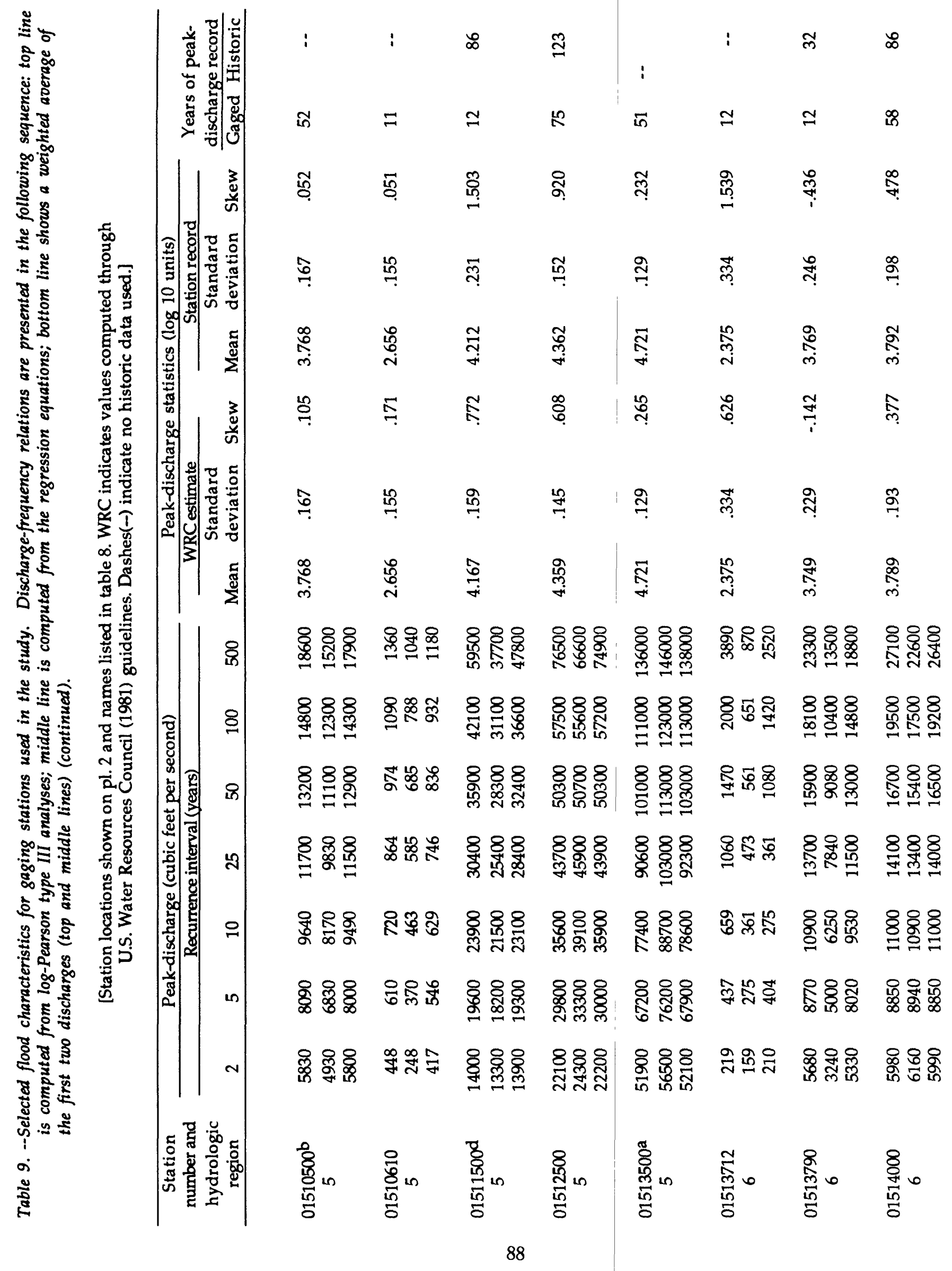




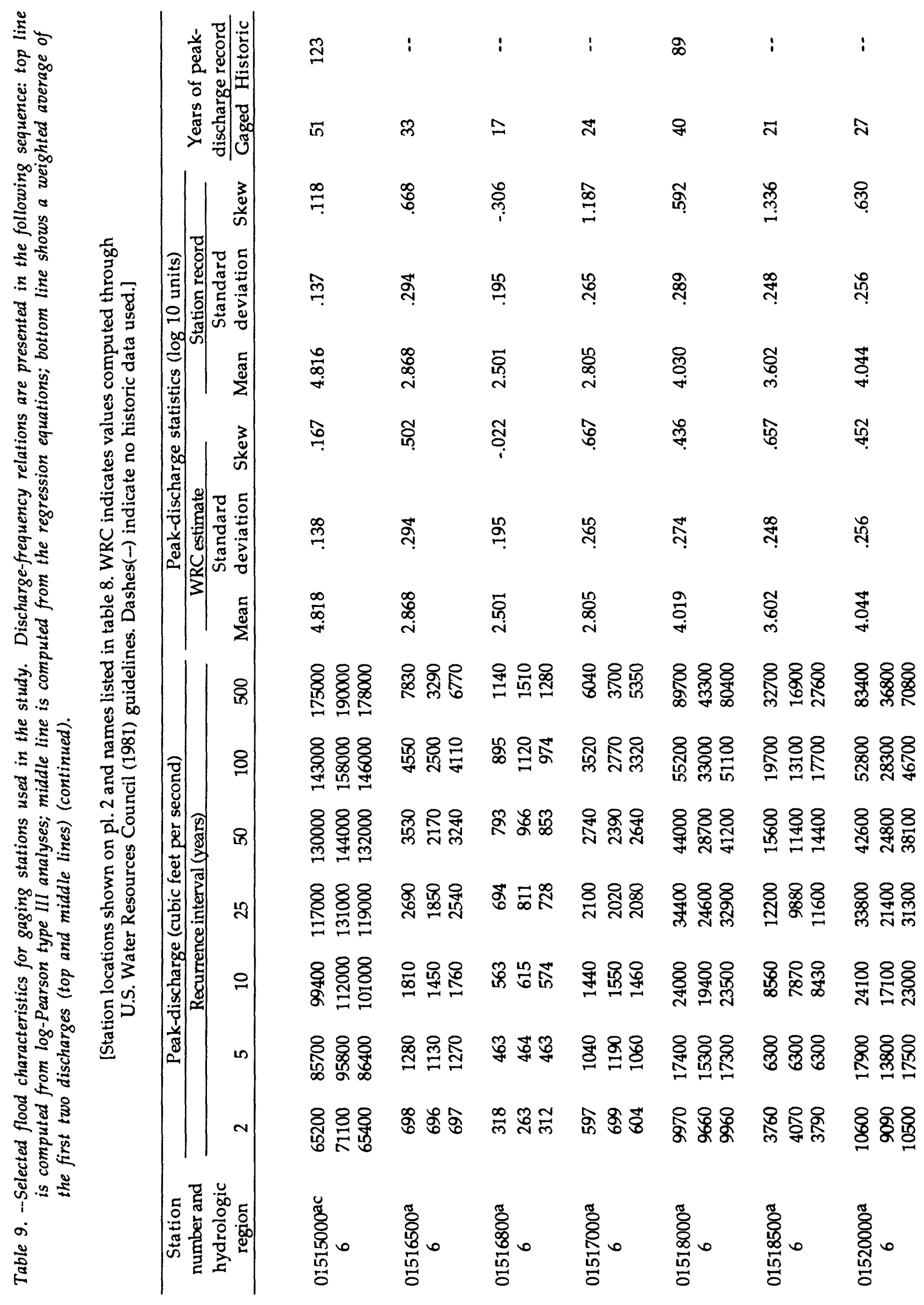



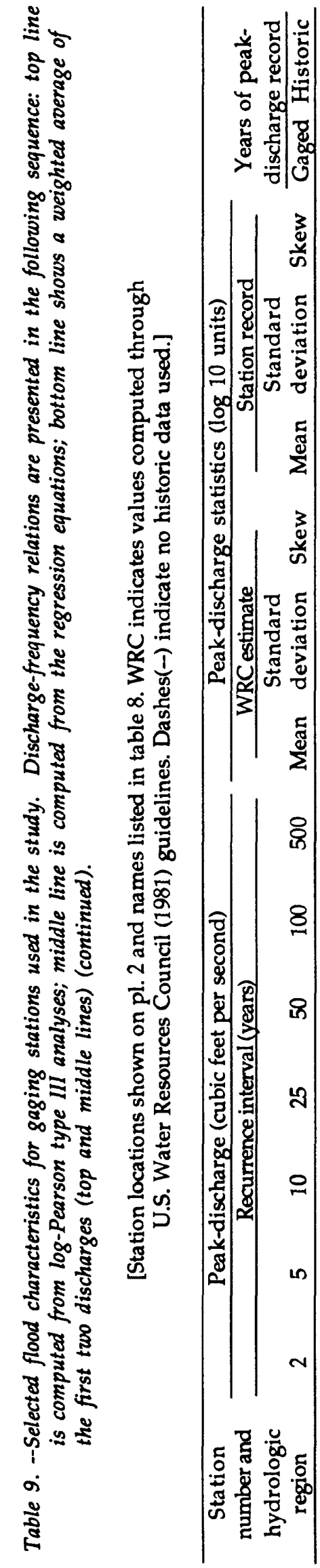

ล : กิ क्ष

in 2 in

F $=$ के के के के का

ণิ

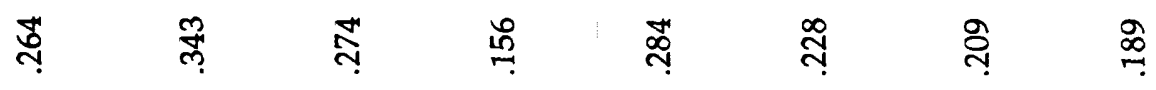

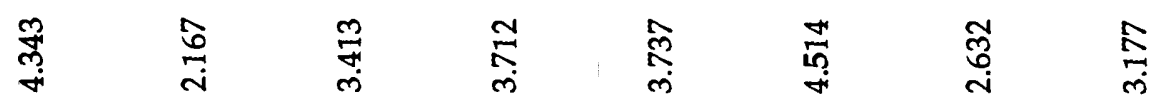

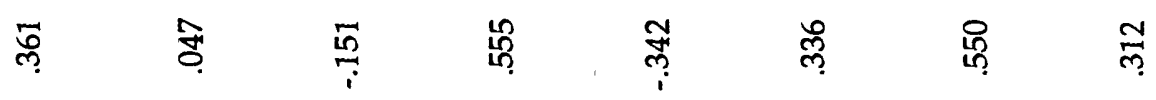

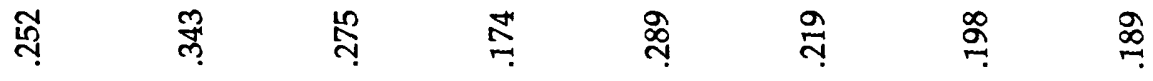

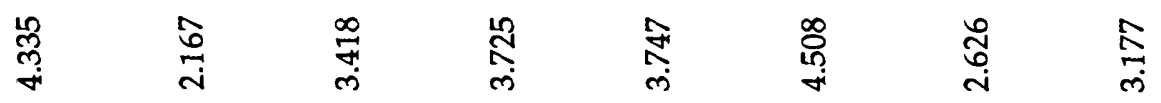

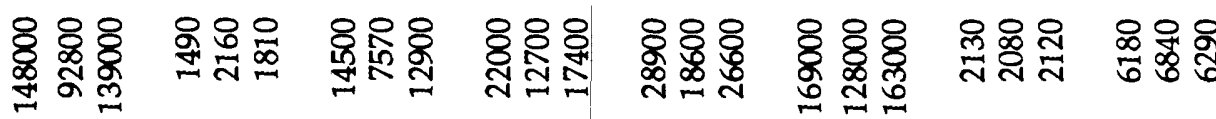

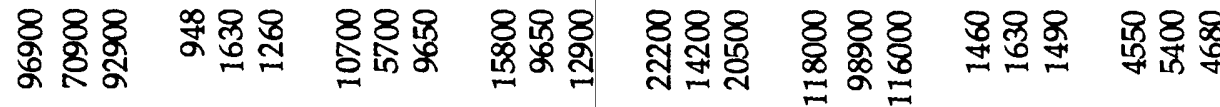

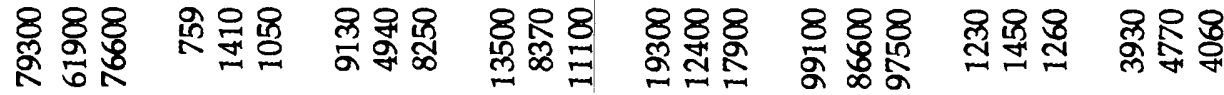

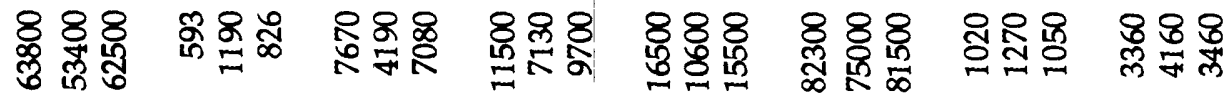

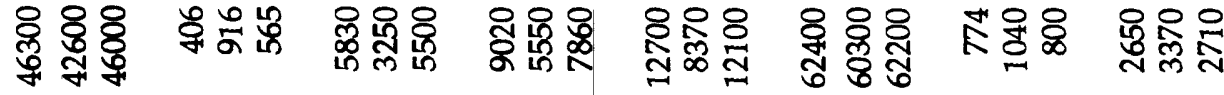

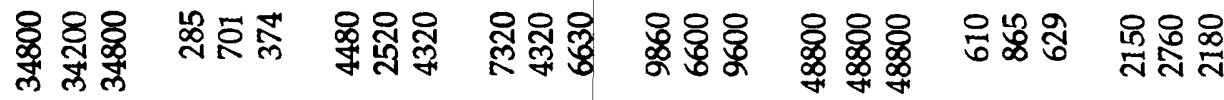

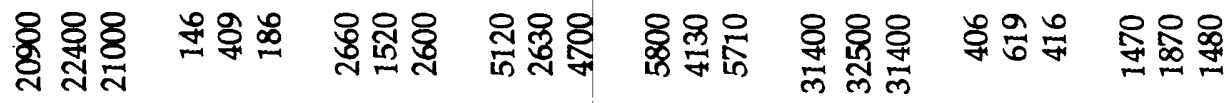

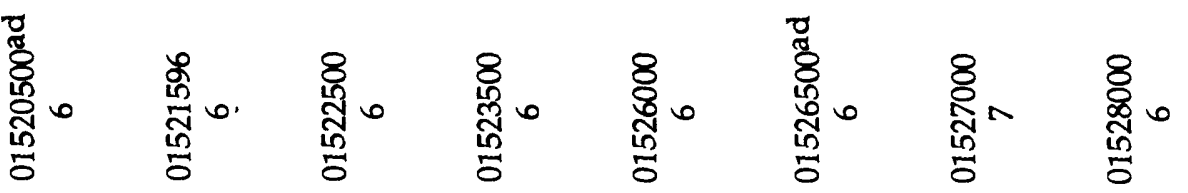




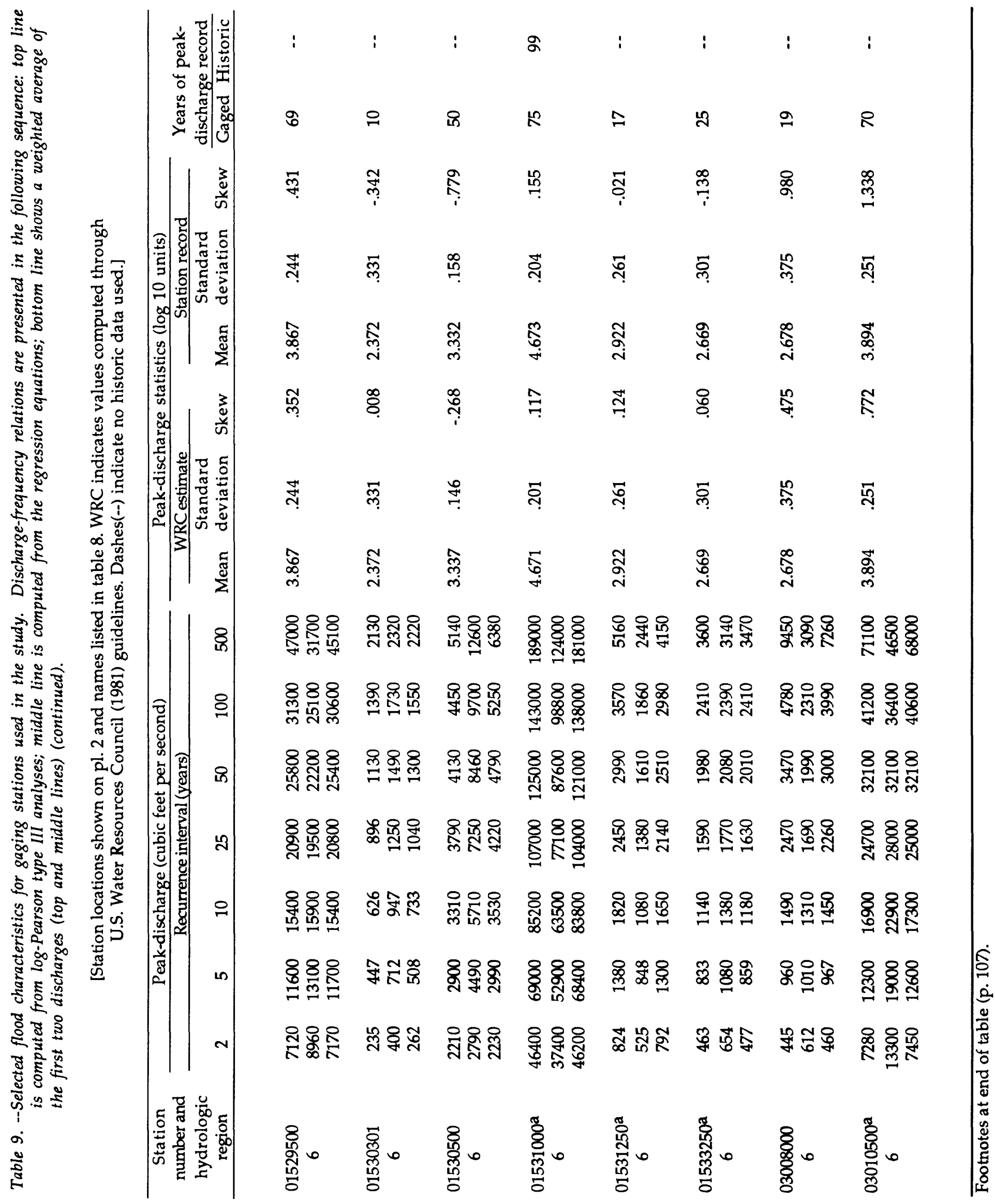




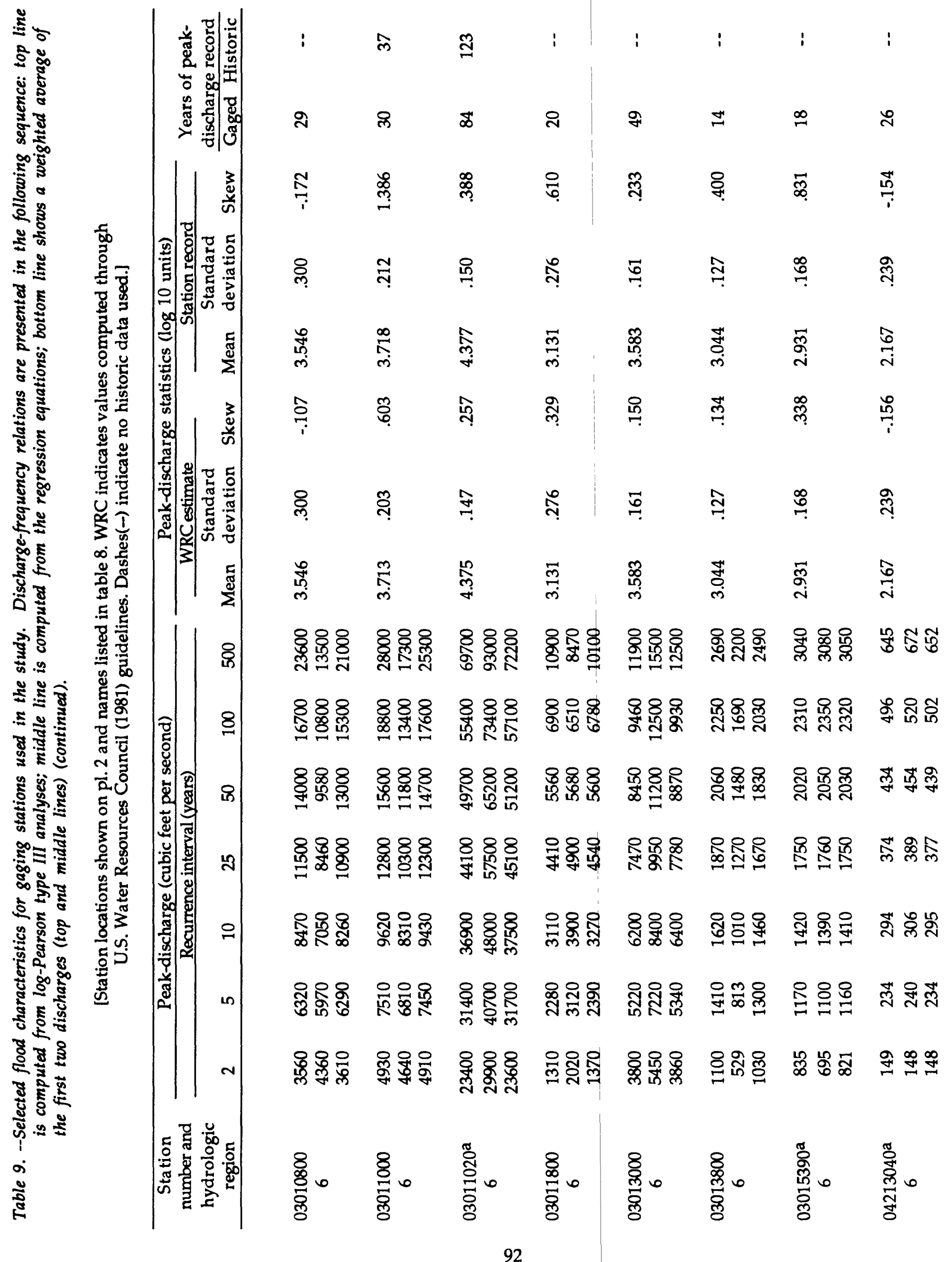





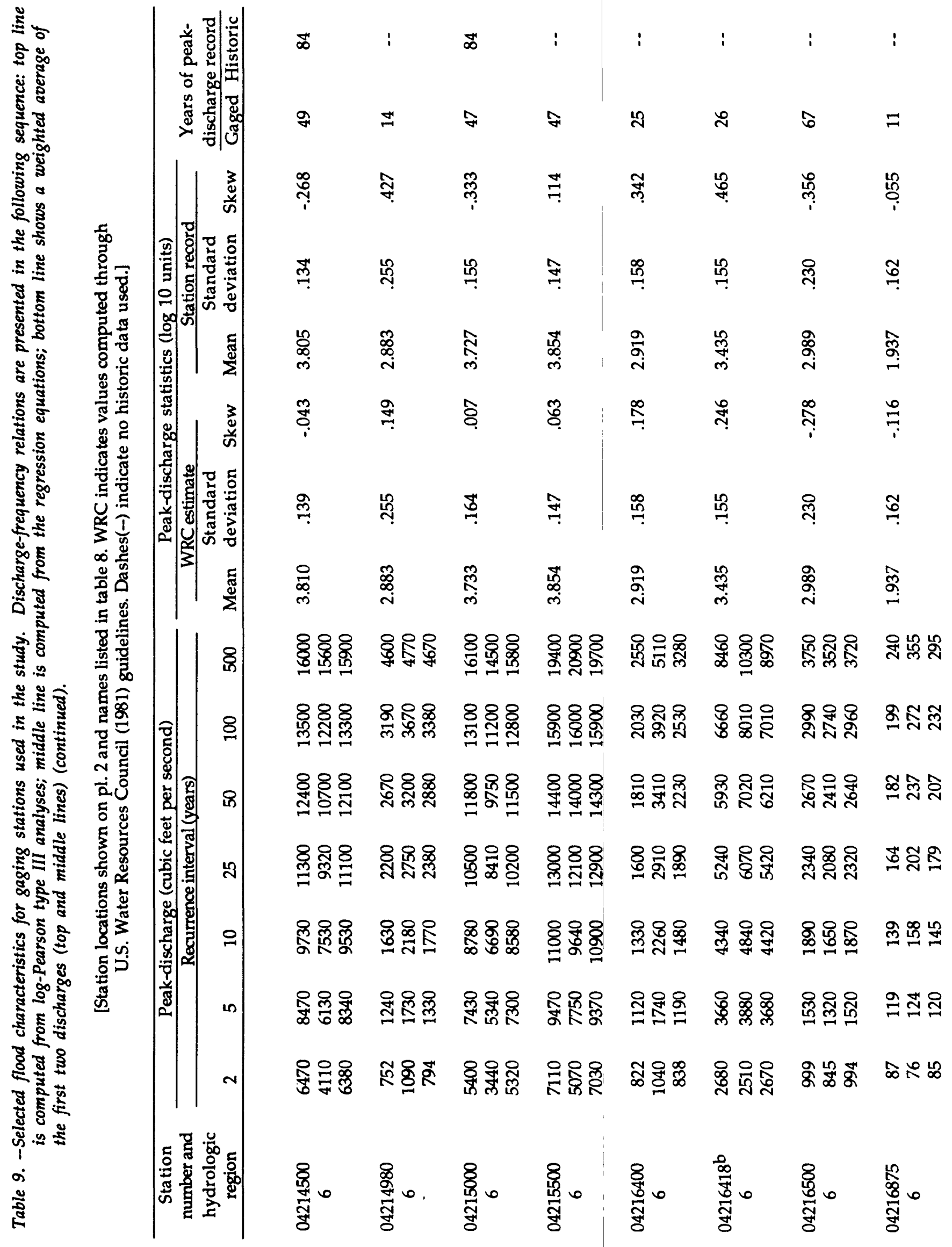




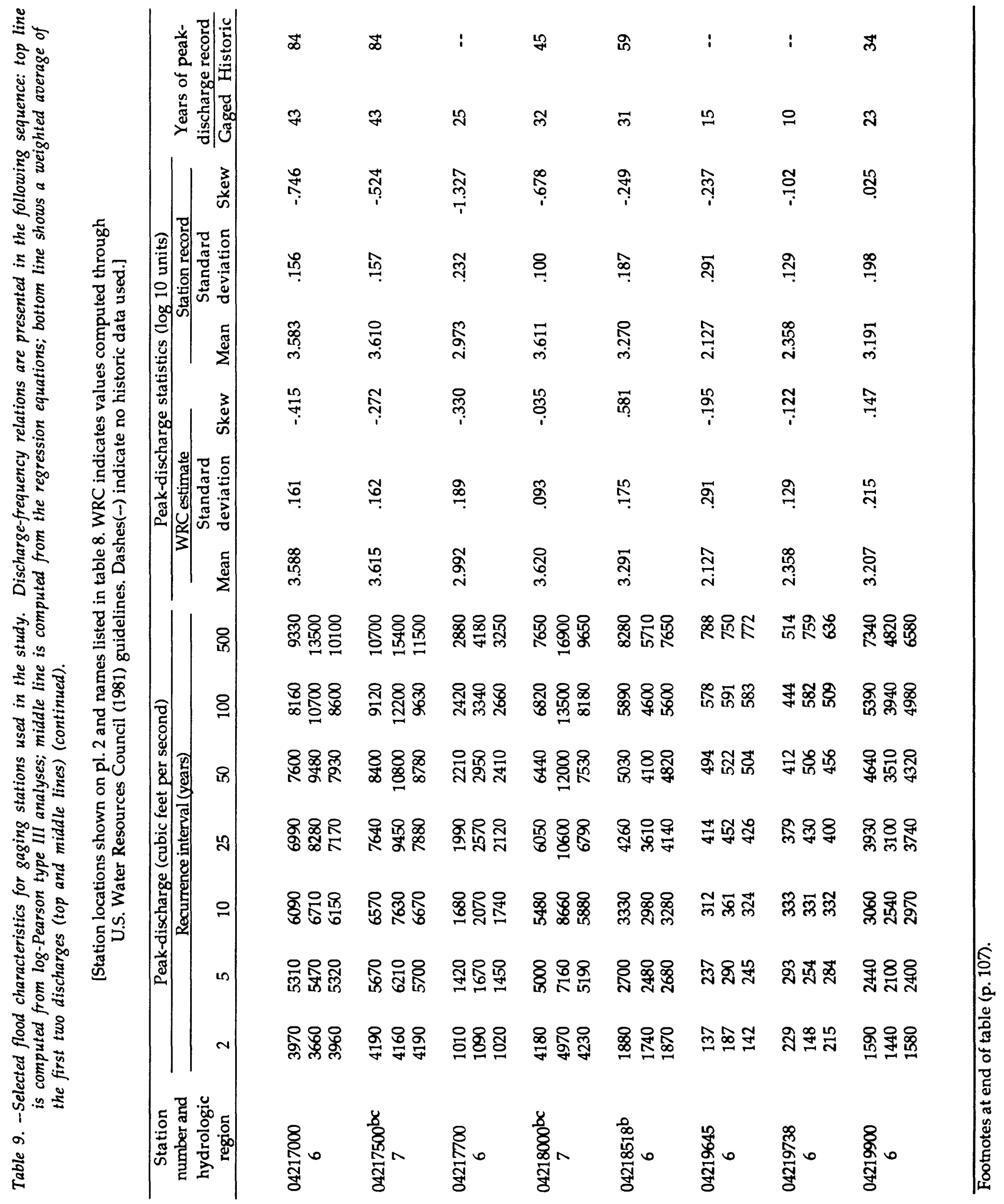




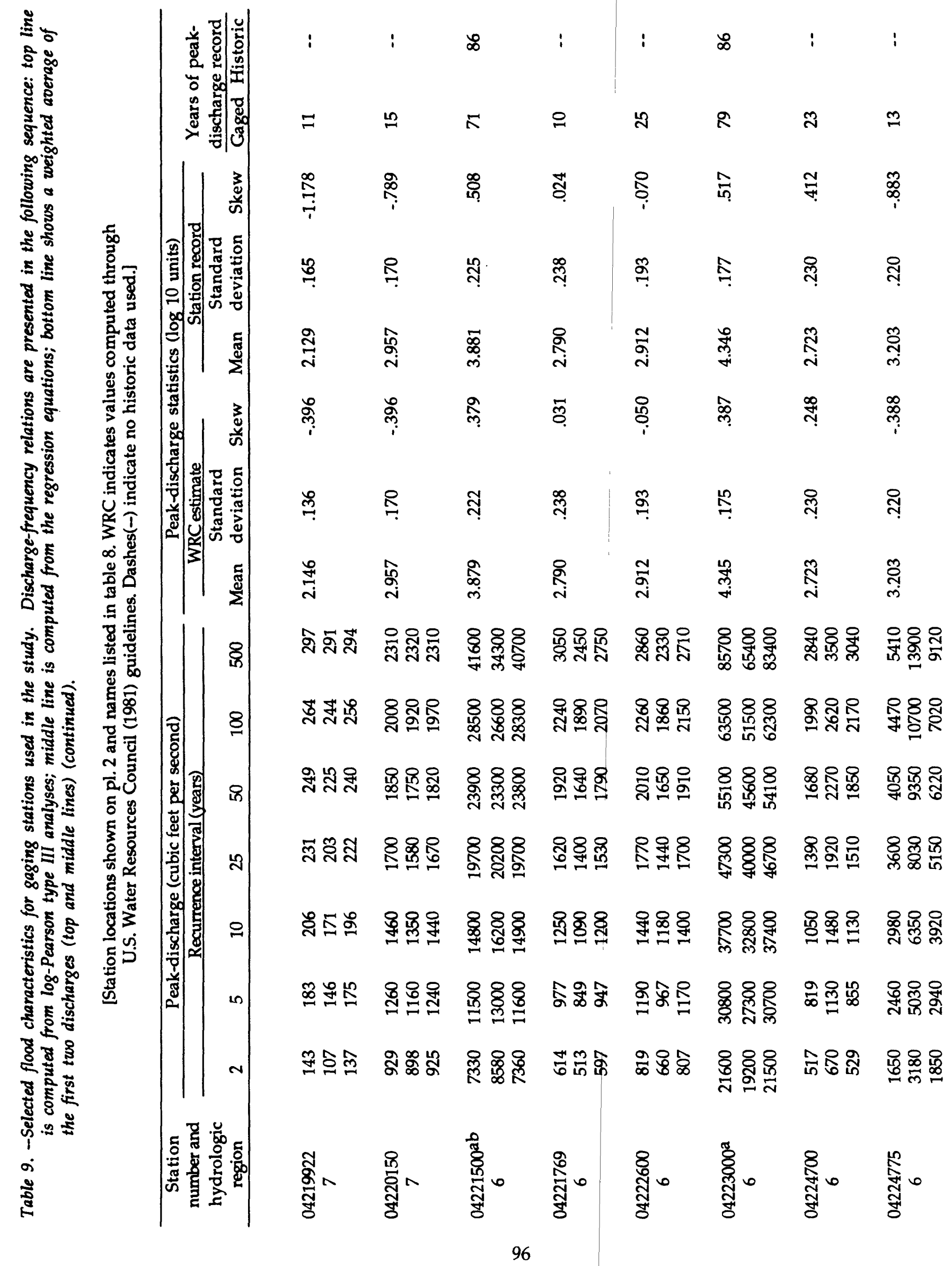




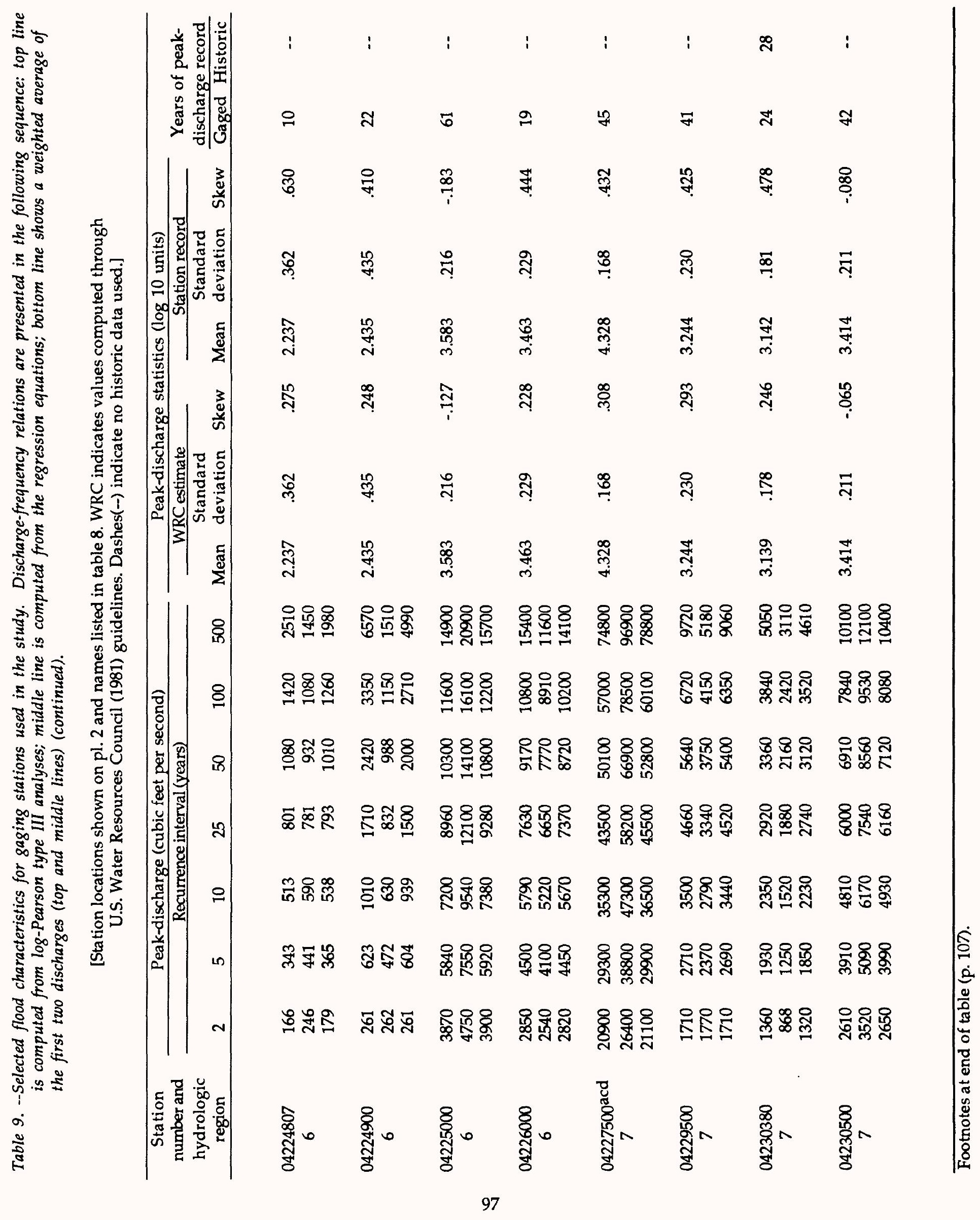




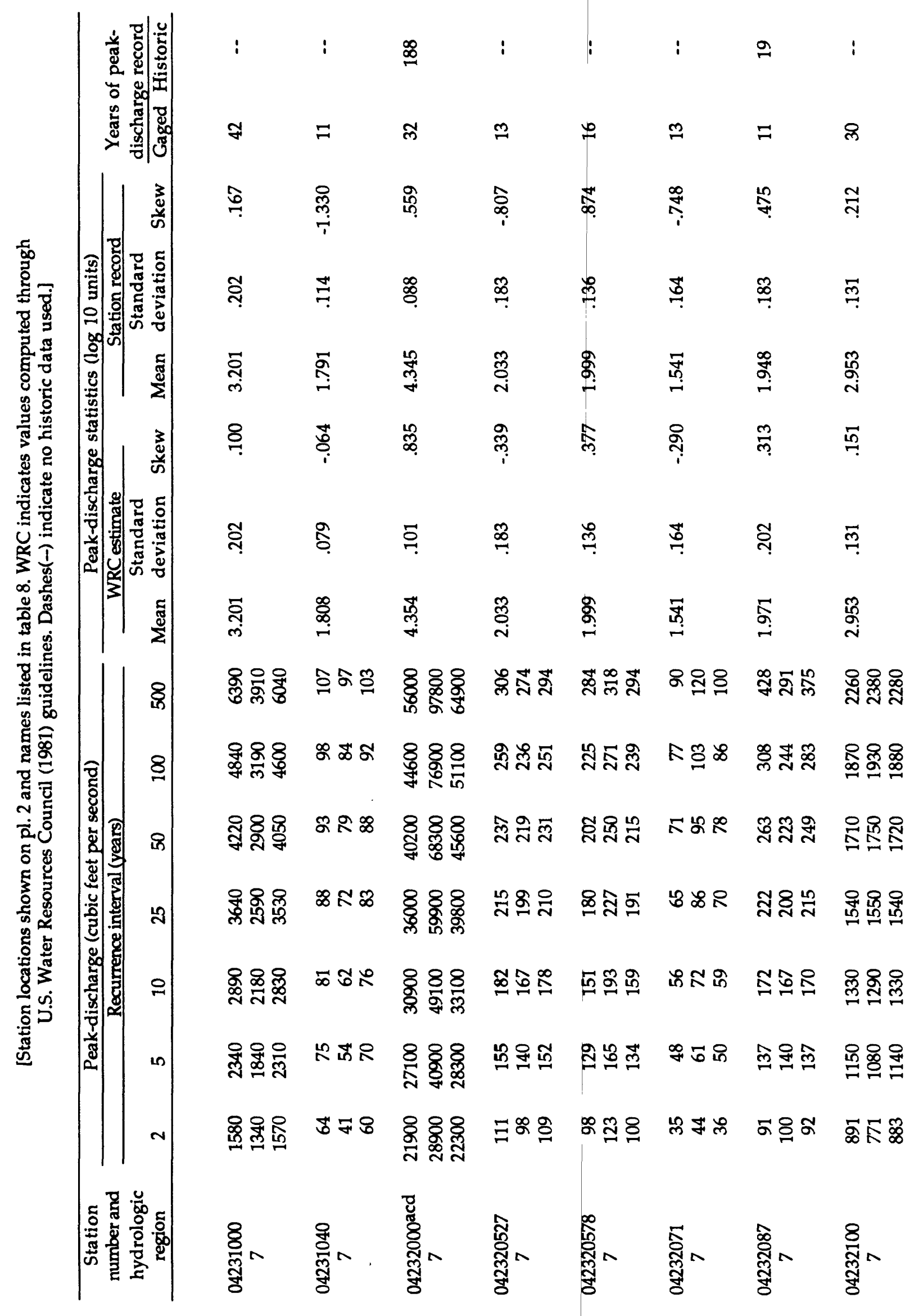




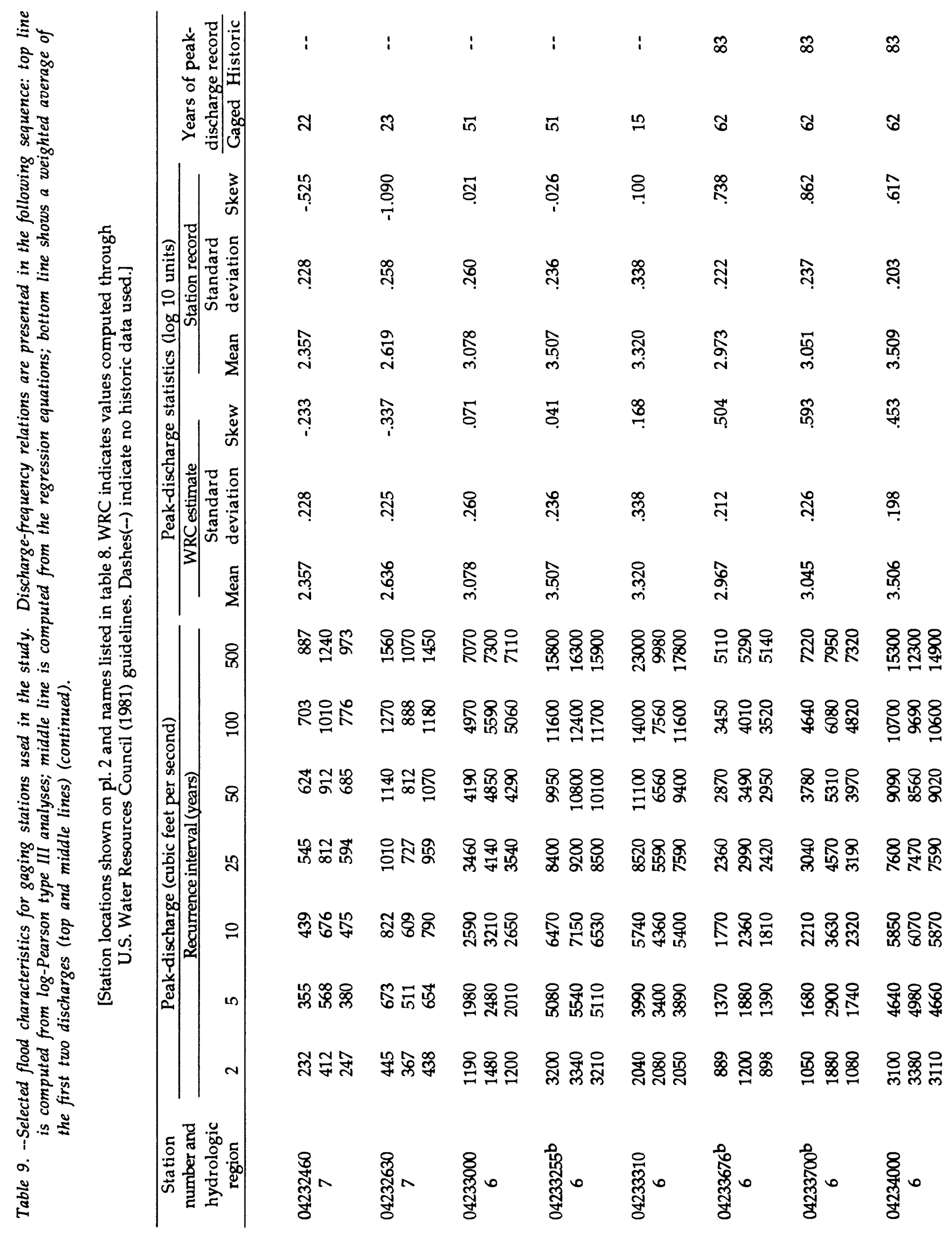




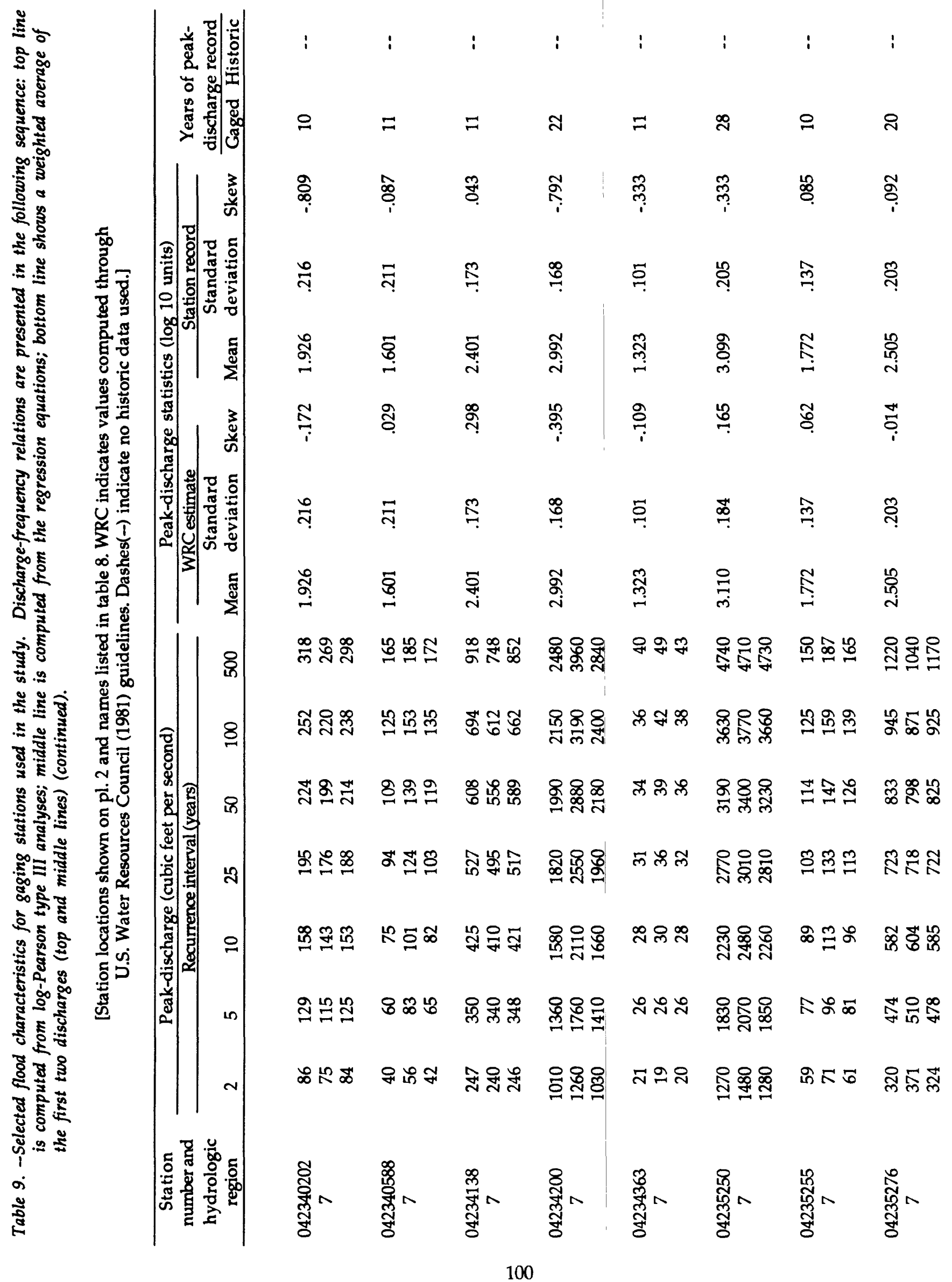




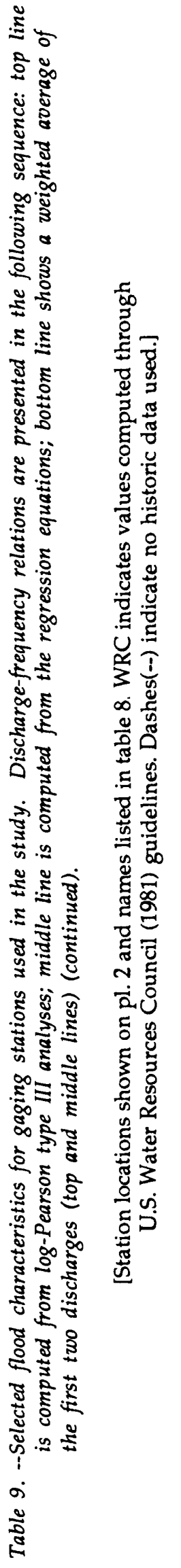

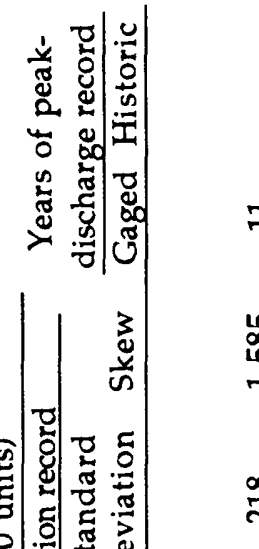

$=\quad \pi \quad \circ \quad \infty \quad \% \quad \pi \quad \pi$

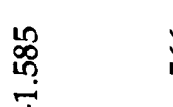

น̊ำ

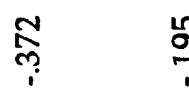

$\stackrel{8}{?}$

ঙุ

$\stackrel{\infty}{\text { ஸุ }}$

$\stackrel{ก}{ก} \stackrel{ก}{ก}$

ণ্ণฺ

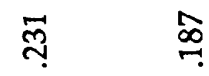

$\stackrel{m}{\rightarrow} \stackrel{\infty}{\rightarrow}$

艿

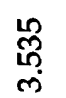

๙ุ

ôे

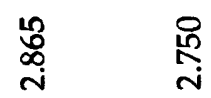

용

尔

ণั

$\infty$

$\stackrel{12}{\rightarrow}$

이ำ

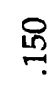

กำ ำ

นิ้

ஸุ $\stackrel{\infty}{\stackrel{\infty}{\leftarrow}}$

$\stackrel{\leftrightarrow}{\rightarrow} \stackrel{\stackrel{8}{\rightarrow}}{=}$

艿

㠃

突

$\stackrel{\mathscr{7}}{\mathfrak{7}}$

ఫे

芳

สํํㅇㅇㅇ

웡유:

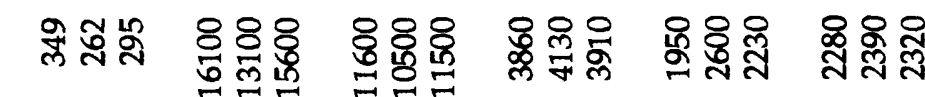

윳융

88

莫哭

8 웅용

융융 융귱요

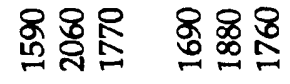

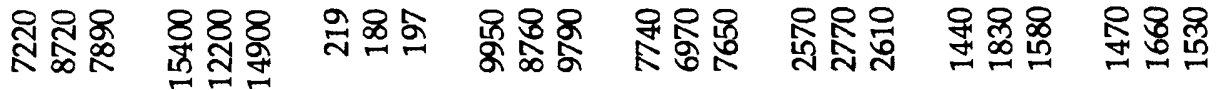

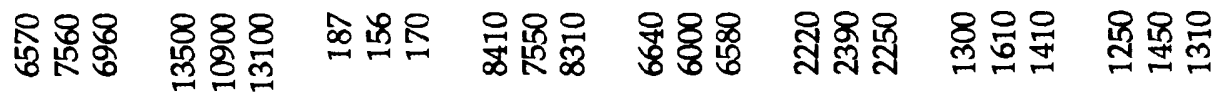

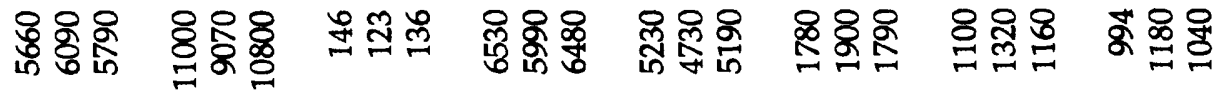

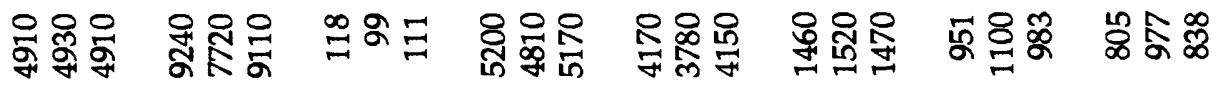

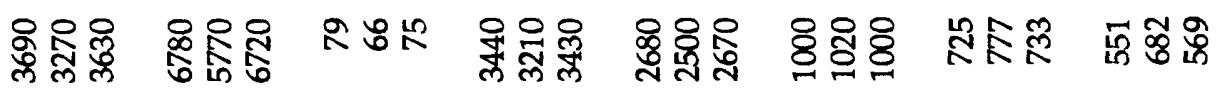

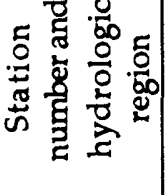

ชి

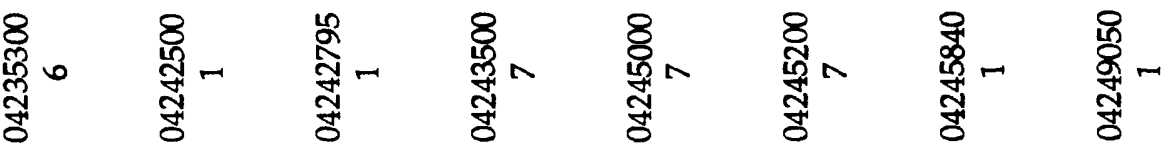




$\approx$

क 8 8 $8=$

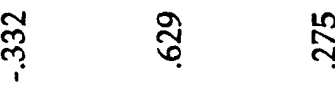

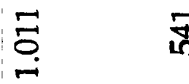

ॠ్

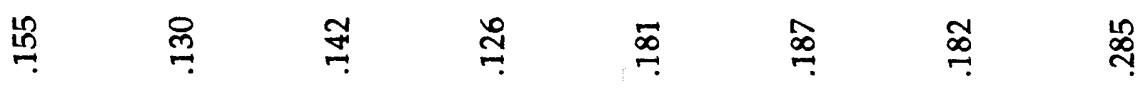

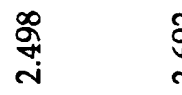

$\underset{\substack{\overrightarrow{0} \\ m}}{\substack{\infty \\ \infty}}$

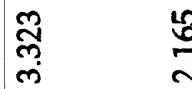

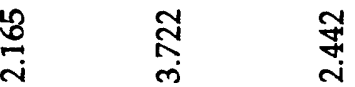

$\stackrel{\infty}{?} \quad$

in $\stackrel{0}{\text { in }}$

\$̦

$\stackrel{\leftrightarrow 0}{\sim}$

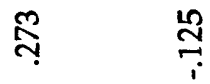

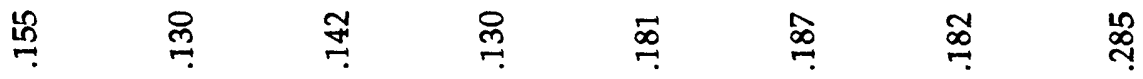

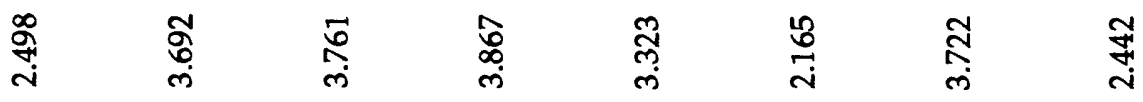

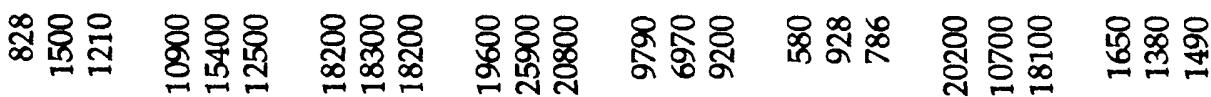

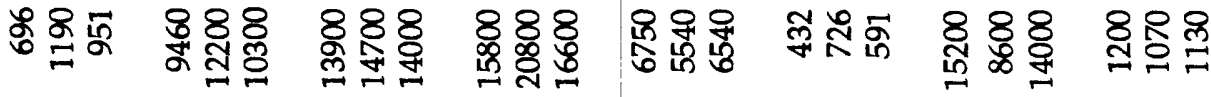

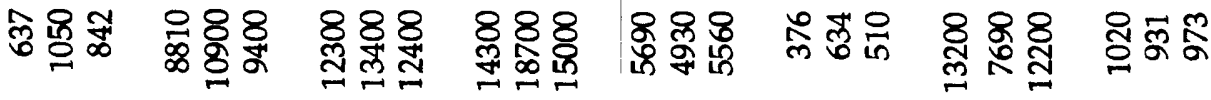

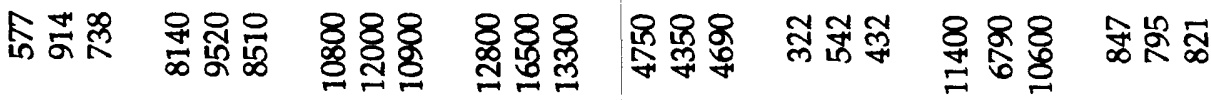

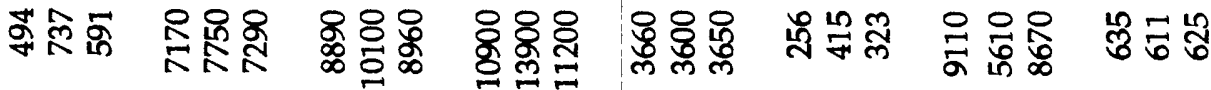

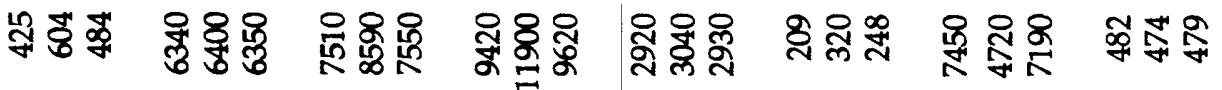

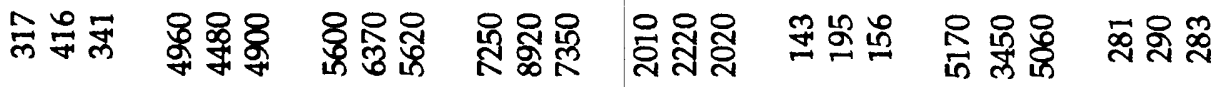

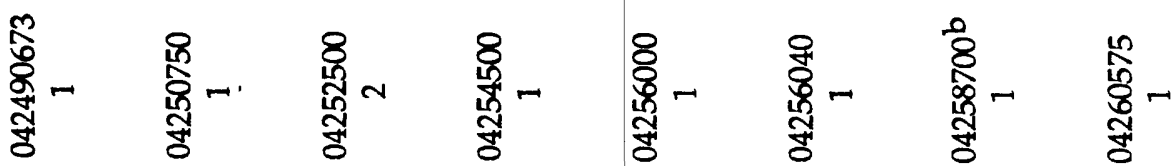




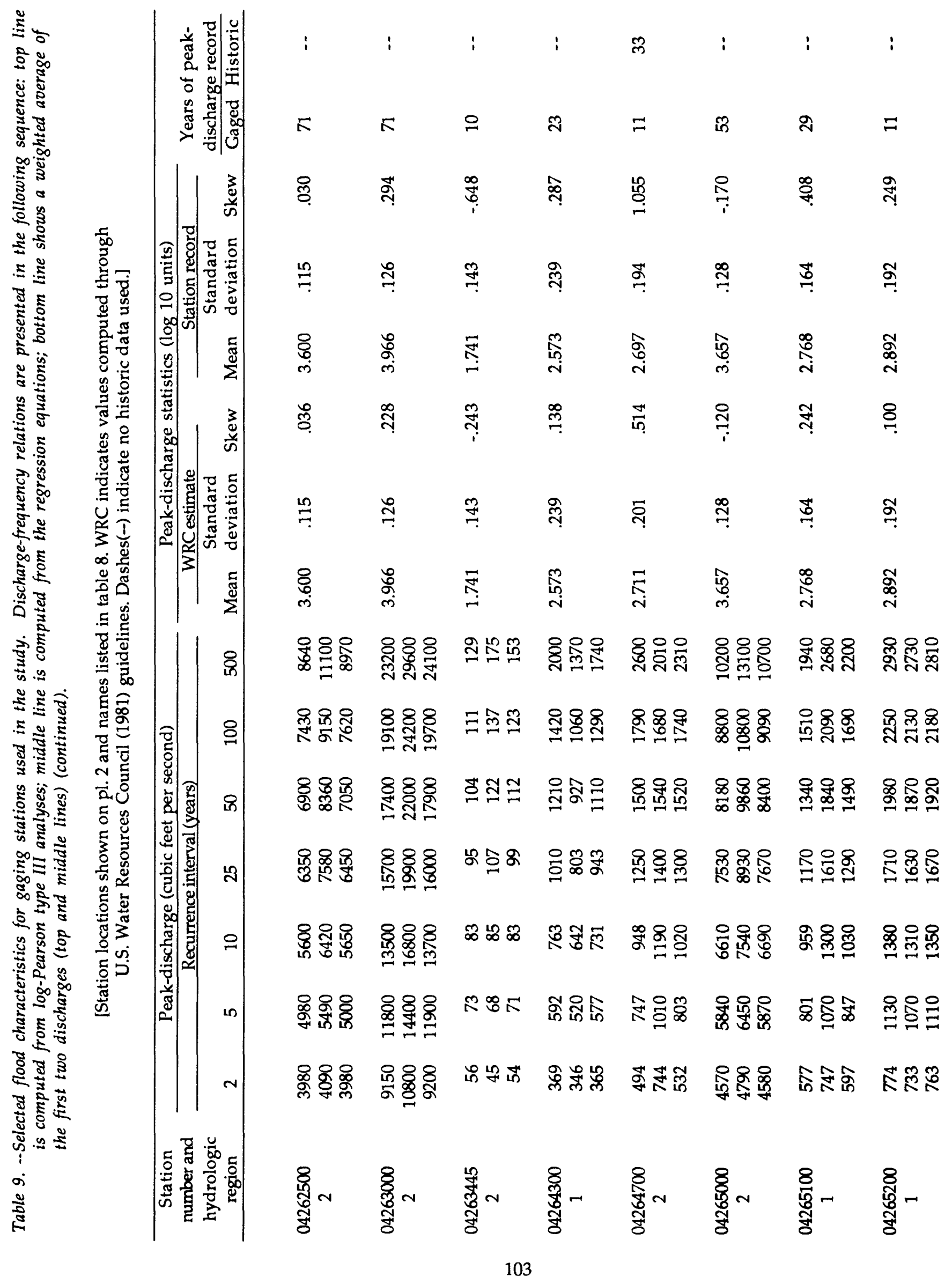




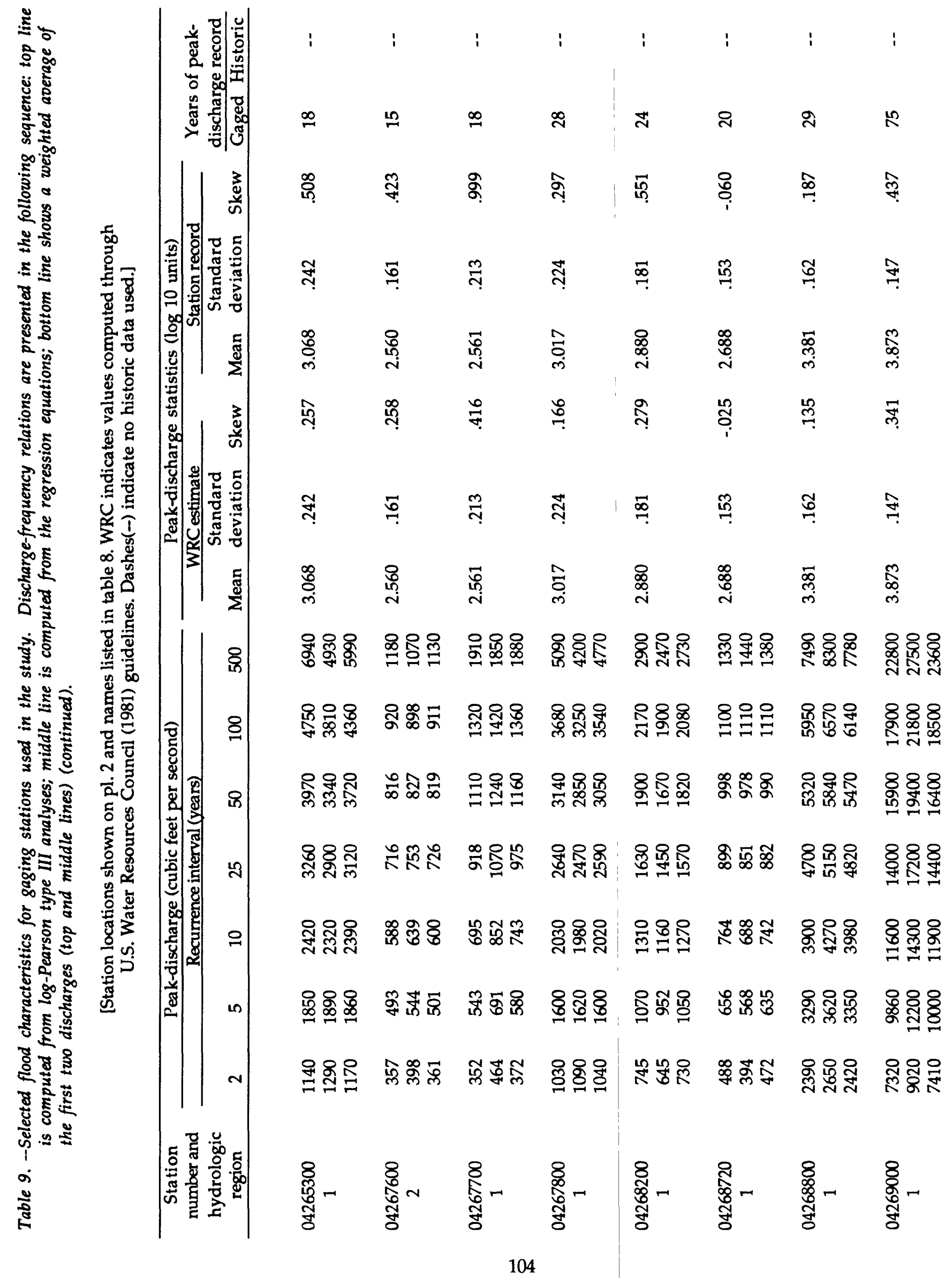




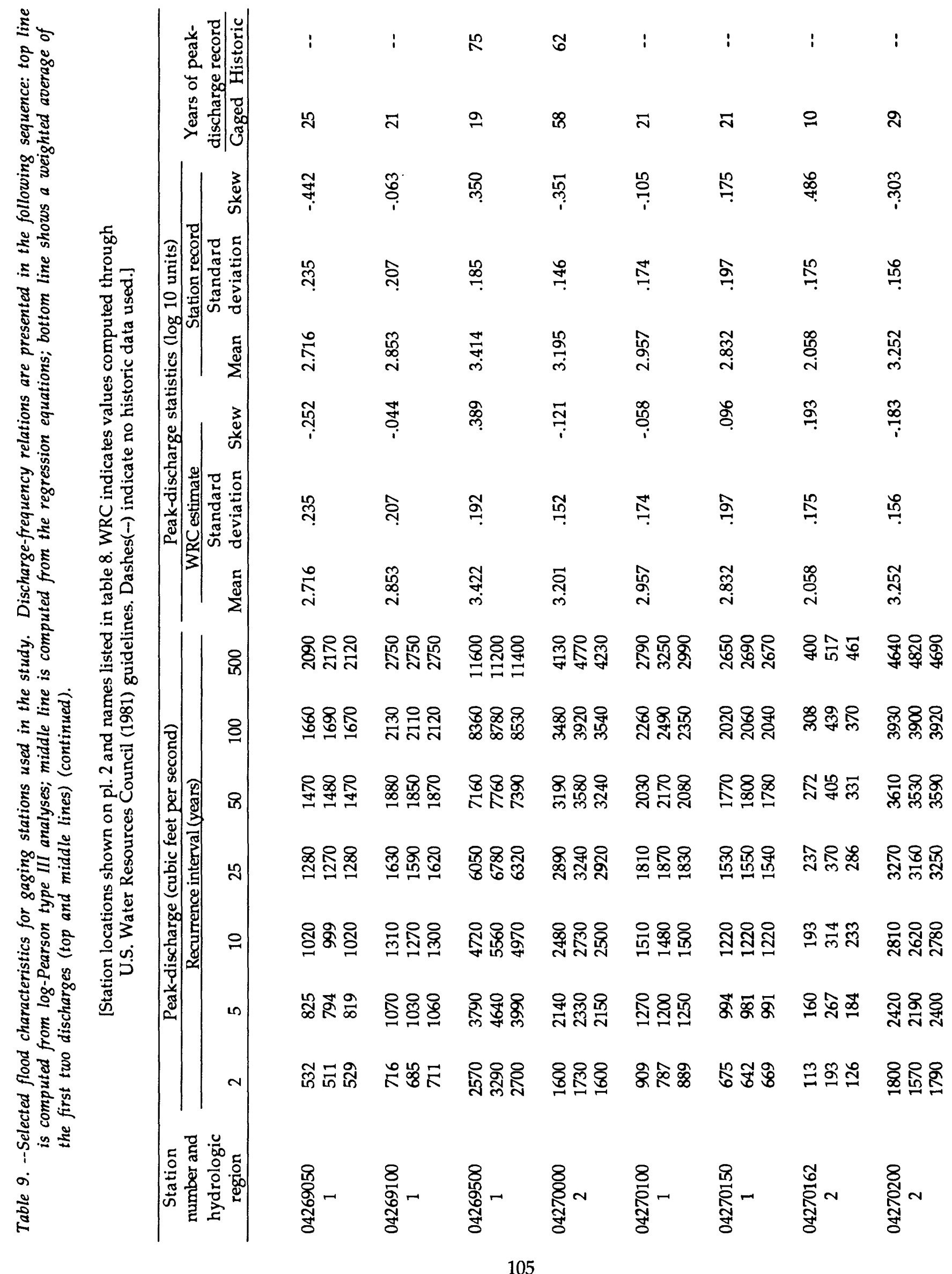




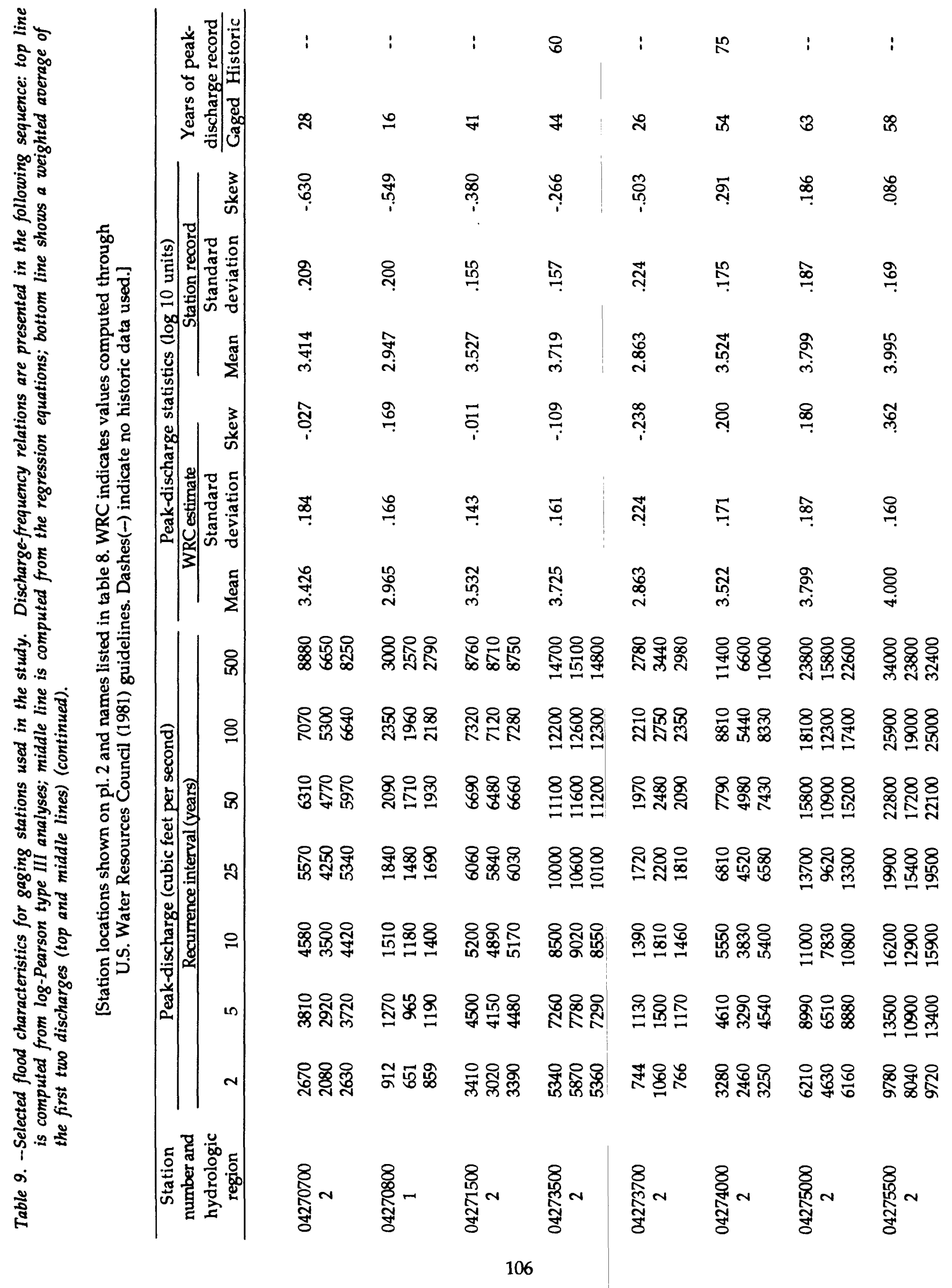




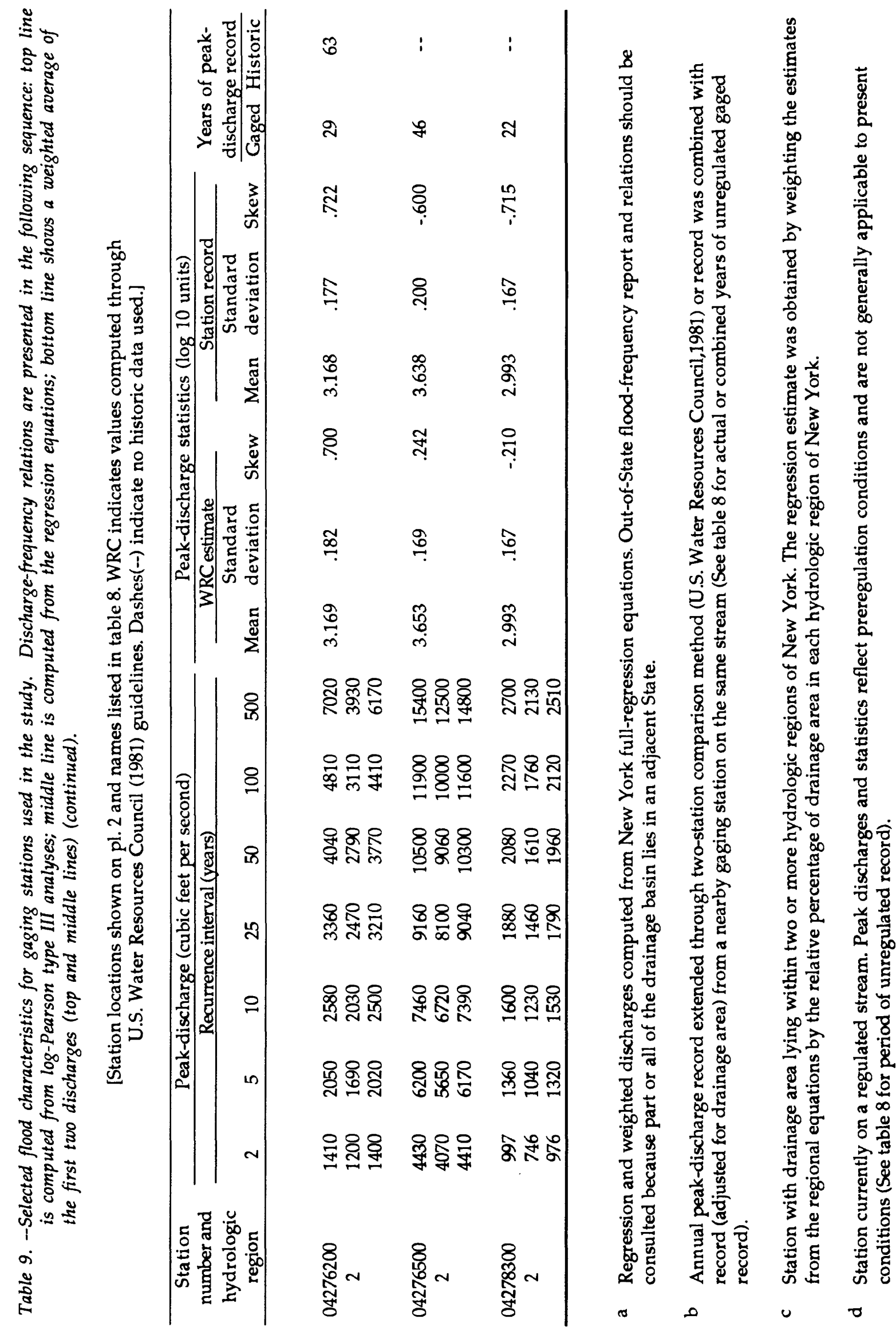


Table 10. -- Selected basin characteristics for gaging stations used in the study. 


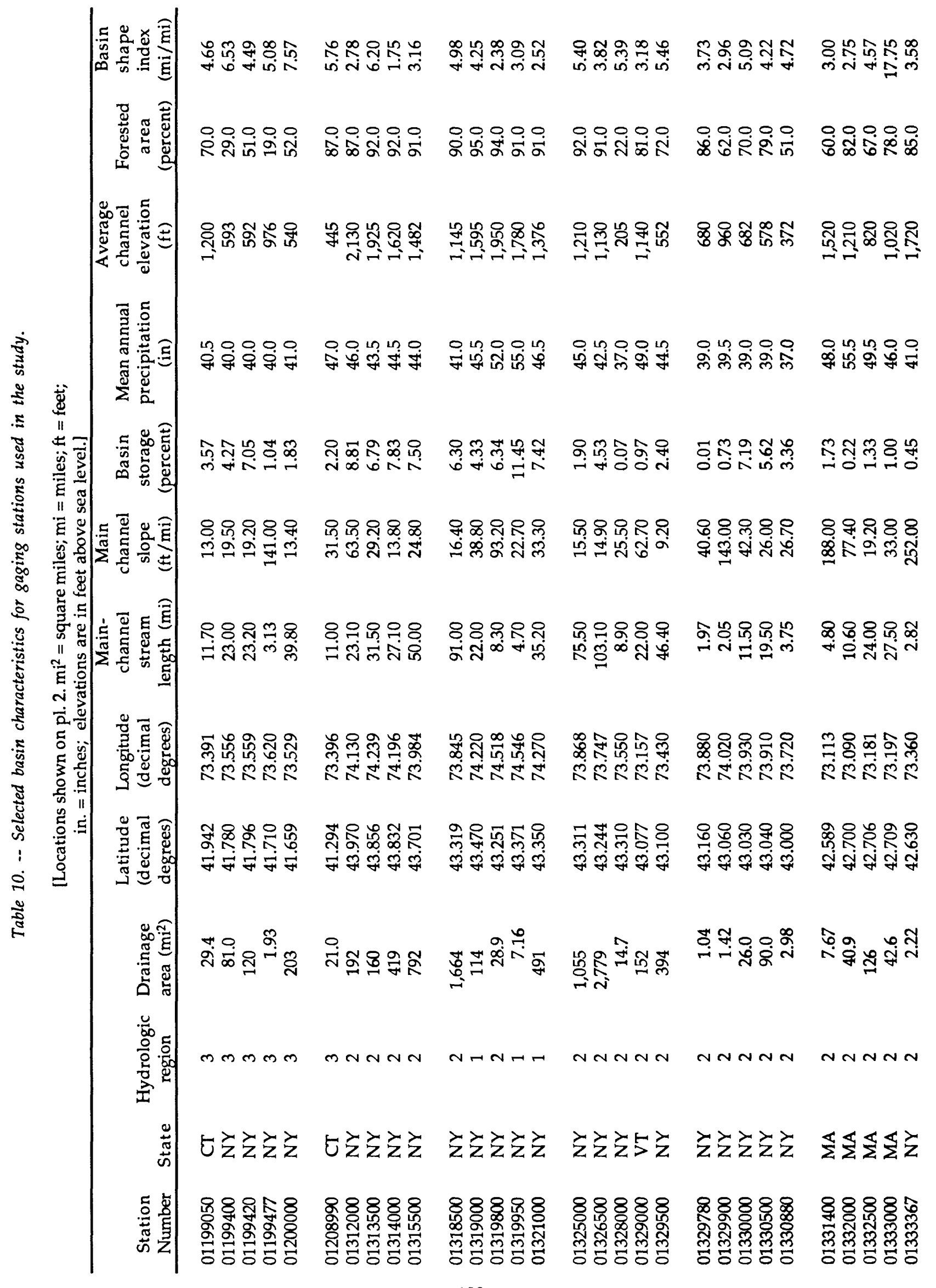




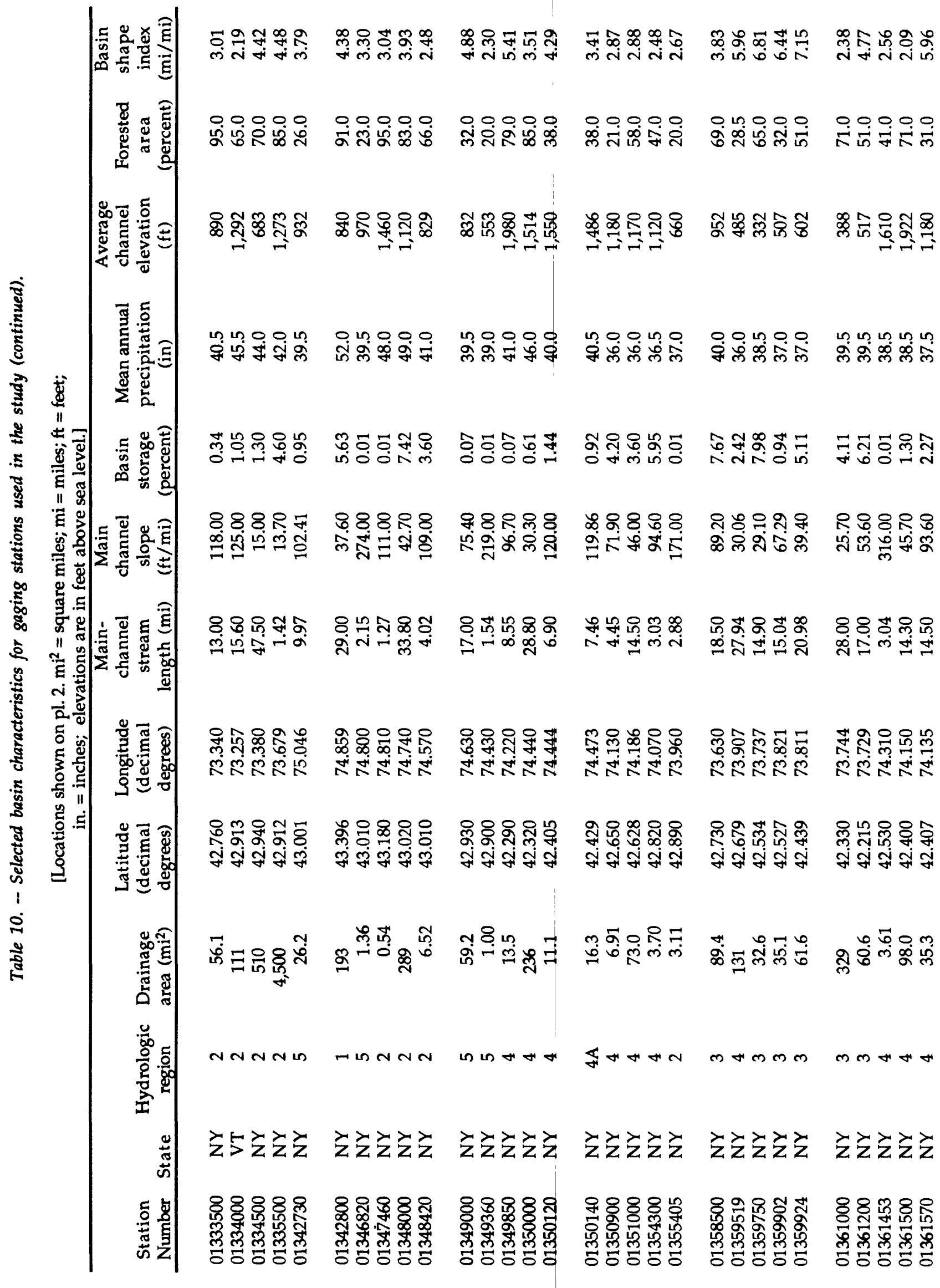




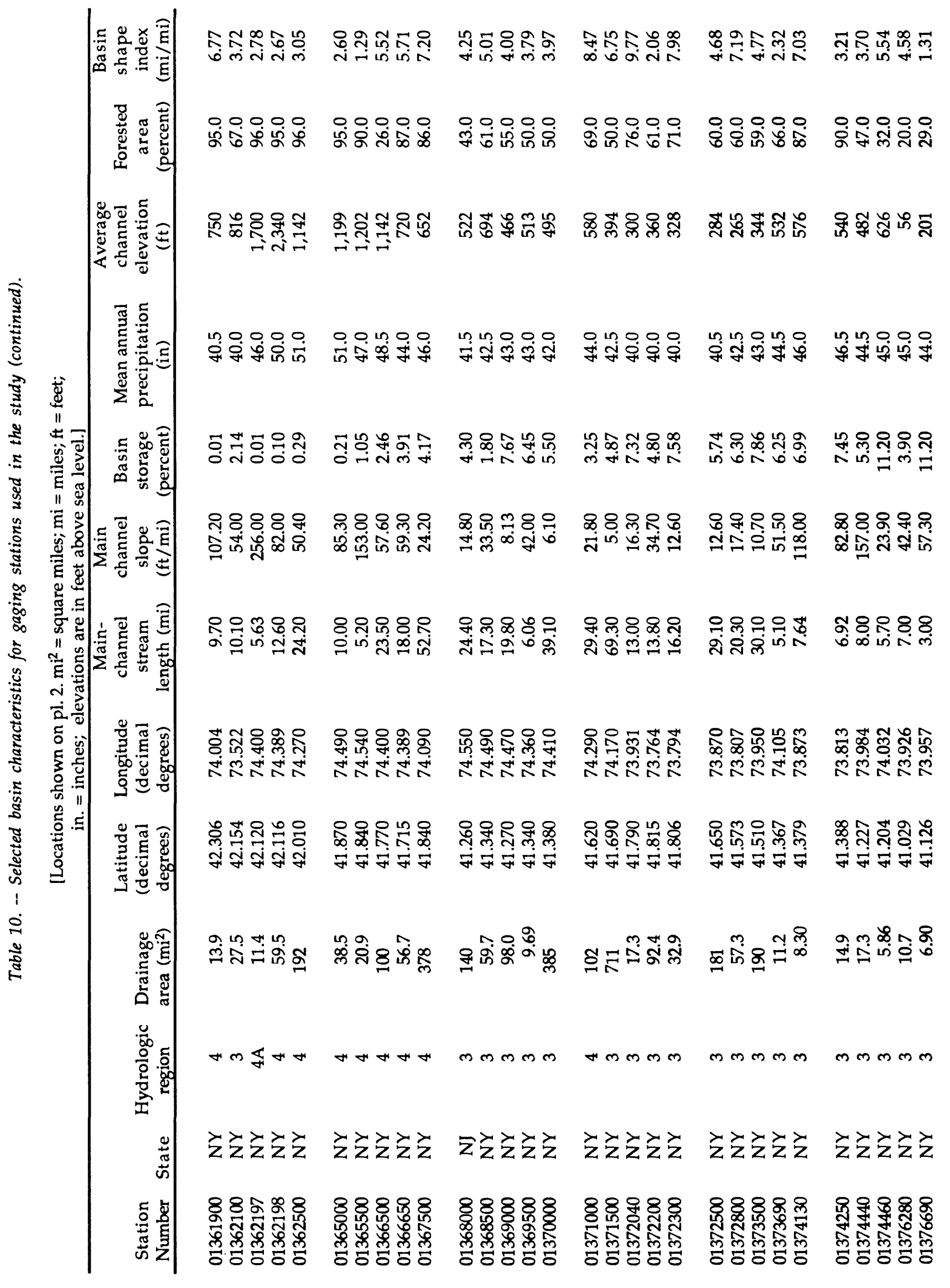


|ี

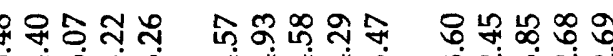

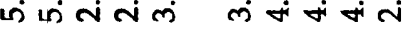

में ले

लें⿰กั

0.0000 .000

0.000 .0

000000

웅영웅요

$0.00 .0 ㅇ$

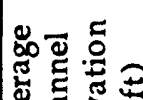

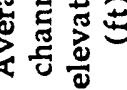

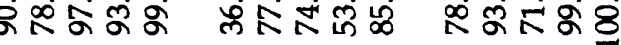
कू⿻

मำ

조옹

00000 no no 00 o 00 in

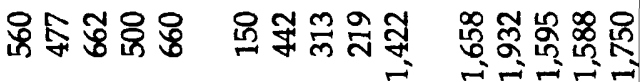

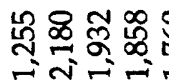

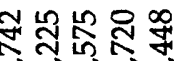

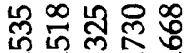

承

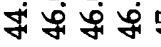

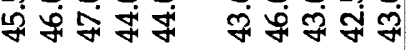

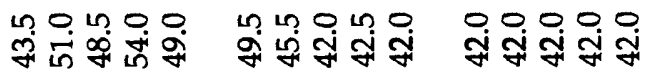

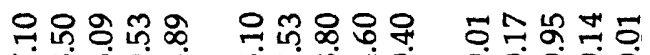

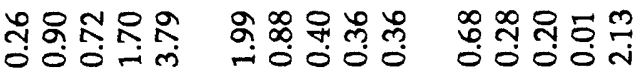

$\wedge \infty \omega$

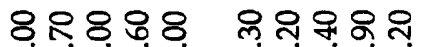

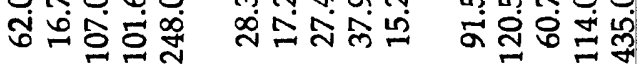

영융ㅇㅇㅇㅛ

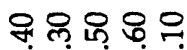

80888

ดู่

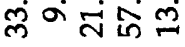

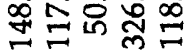

유유유ㅁㅠㅠㅇㅛ

48 응ㅇ

우늄요유융 등ำ

สู่ IO

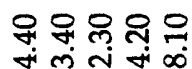

준ำ응 แก

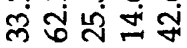

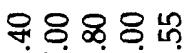
inत लंख

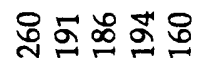

궁응ㅇㅇㅇㅠ.

앵융ㅇㅇㅇ

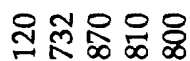

융응유워

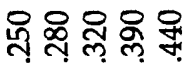

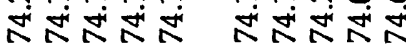

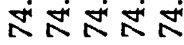

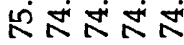

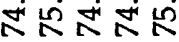

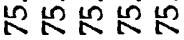

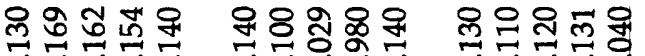

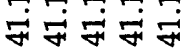

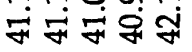

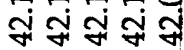

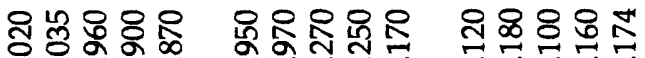

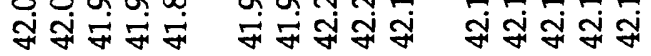

है.

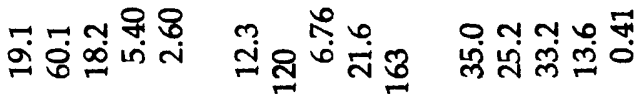

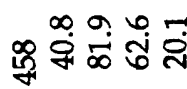

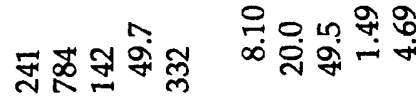

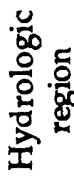

क्यात

M⿻上丨

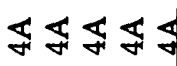

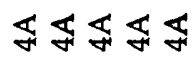

$\mathbb{J}$ 舟的的

in $\operatorname{ton}$ in $\cos$

そ穵学

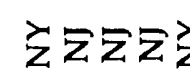

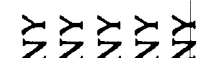

そううう

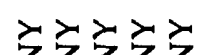

そ文文公文

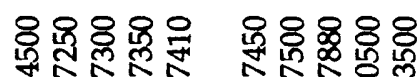




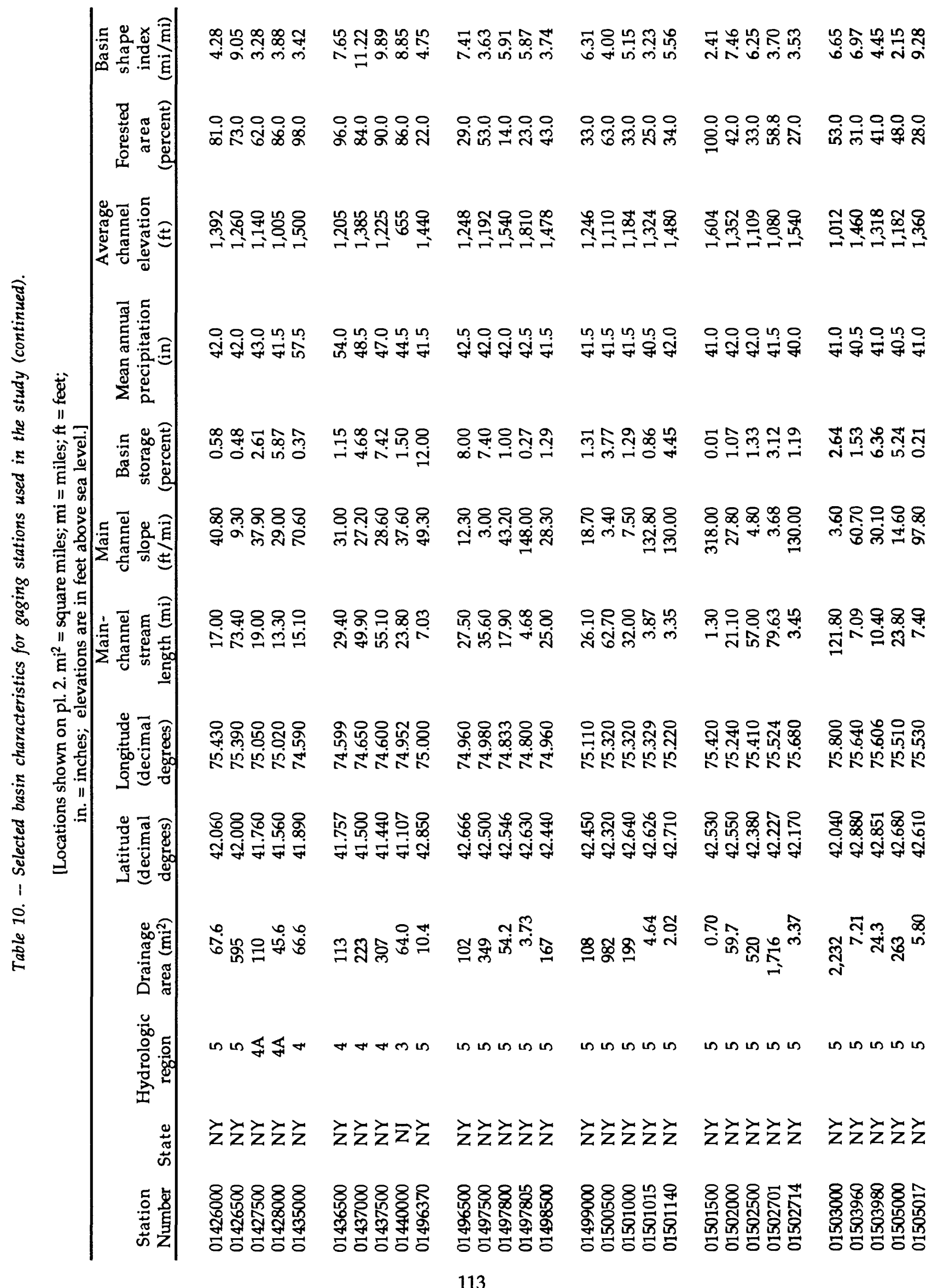




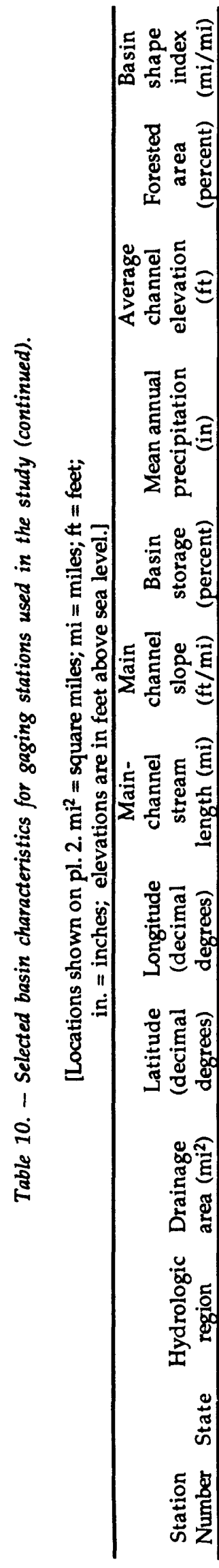

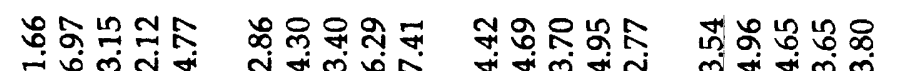

제요요요

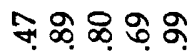

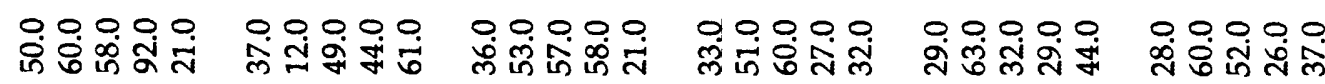

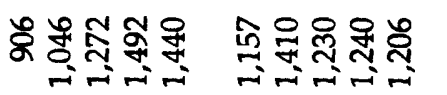

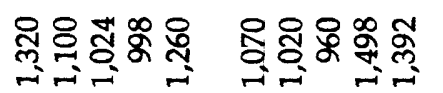

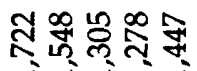

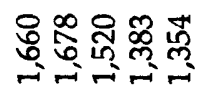

우운 누요

$\ln 0.010$

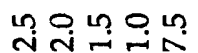

웅요 느웅

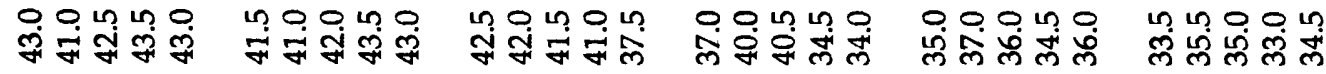

$\ln \ln 0.0 .10$

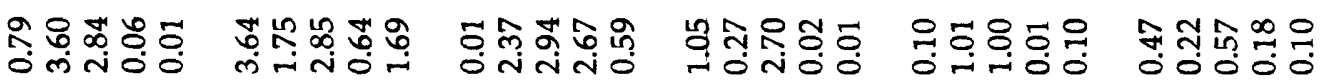

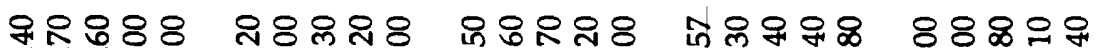

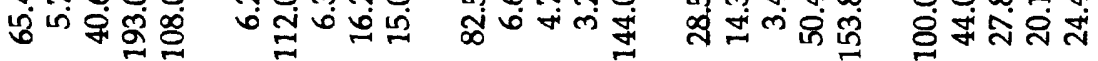

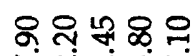
ลู่งู่

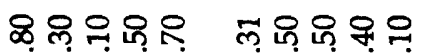

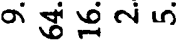
मुलिल्लिं

능ㅇㅇ중 अंगำ

송요용

ํㅡㄴ쥬유요 กส่สำ mंत्य

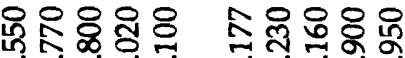

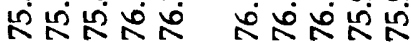

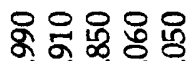
형웅융음

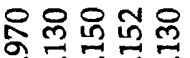

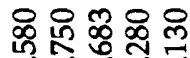

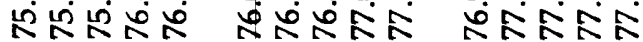
ลลลลล

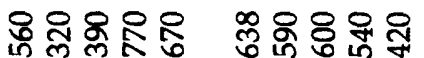

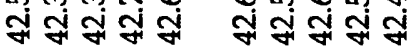

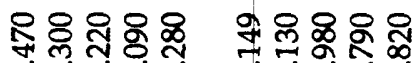

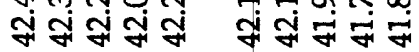

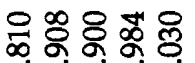

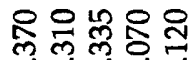

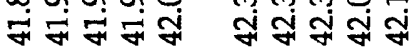

iิ่ ํํำูปิี

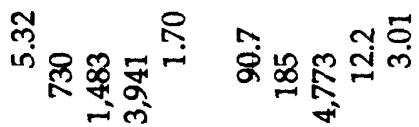

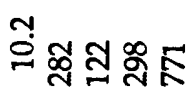
ขึช in

in in in in in in 6 in in in

in in in in 6

60666

66666

6606

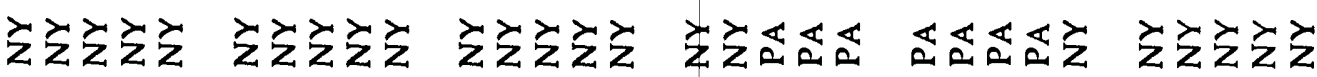

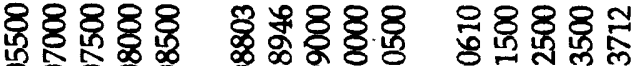

\% 8888 


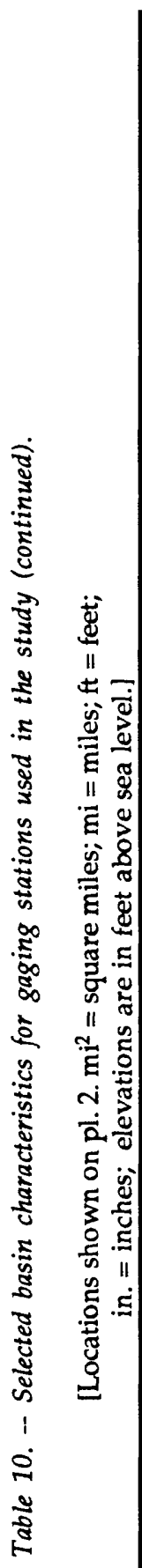

m

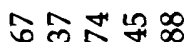

ㄷํㅇํำ

운오으ำ

iก ชูกญ กิ

in

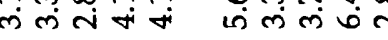

लां लंख

in in $+\infty$ i

in $\infty$ i in $\infty$

0.0 .0 .0

0.0 .00

00000

0.0 .00

0.00 .0 .0

웅요웅요

m웡ํㅇ

สูำํำ 충

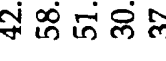

भ भิำ

ले की

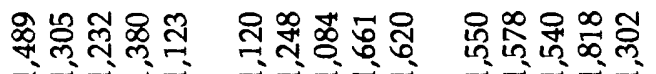

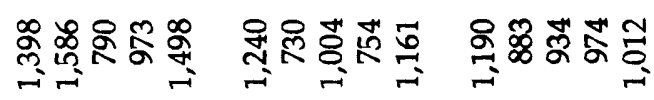

웅요 웅으

웅ㅇㅇ웅

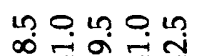

운요웅

nุ

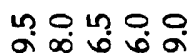

$\sum$

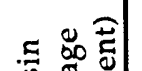

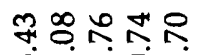

กิ도용ㅇㅇ

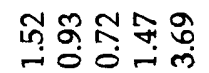

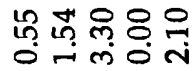

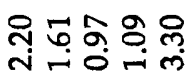

ํํㅇํํ옹

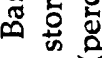

लि-

ㅇํ융ํㅇำ

จิํํำำ

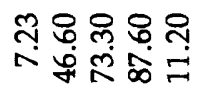

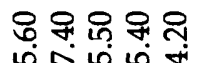

와 위 누 궁요

융요으우 8

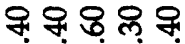

in 0 in

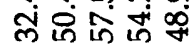

สิ่ ผึ่

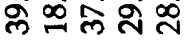

व $\approx \widehat{\vec{\Xi}}$

유음유오요

유풍요

ํㅜㅇㅠํํ요요

총ํำ

ํํ용ํํำ음

용유용

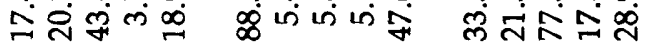

ஸां

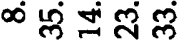

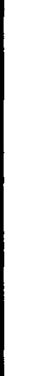

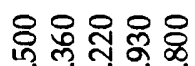

응처ㅇㅠㅠ융

솟ํำ

눙요

육혀늗옹

ㅇํㅇำ

연원용중

रूवं

연

옹ํㅇㅇำ

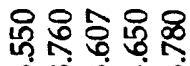

乐舟乐

ㅇํㅇ유뮤용

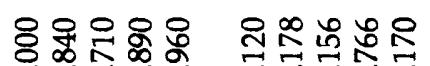

꾹웡영용

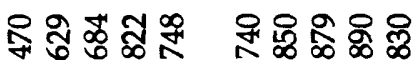
สู่ สู่

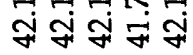

สู่ษ娄

สู่ สู่ สู่

สู่ สู่ สู่ สู่

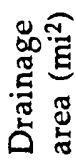

กิ่

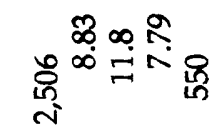

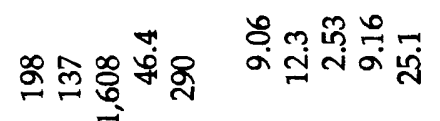

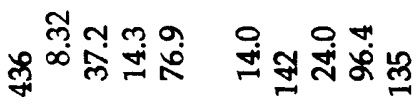

4

$\wedge 606$

66060

66660

60606

66666

66066

空

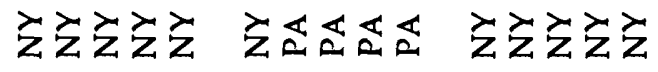

乙むむむる

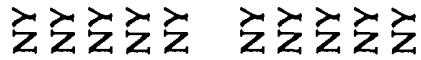

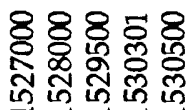

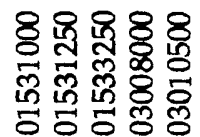

\&్రి

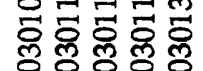

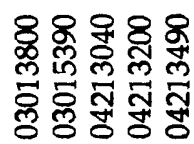

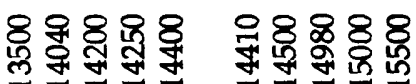

영동응

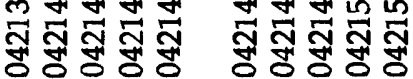




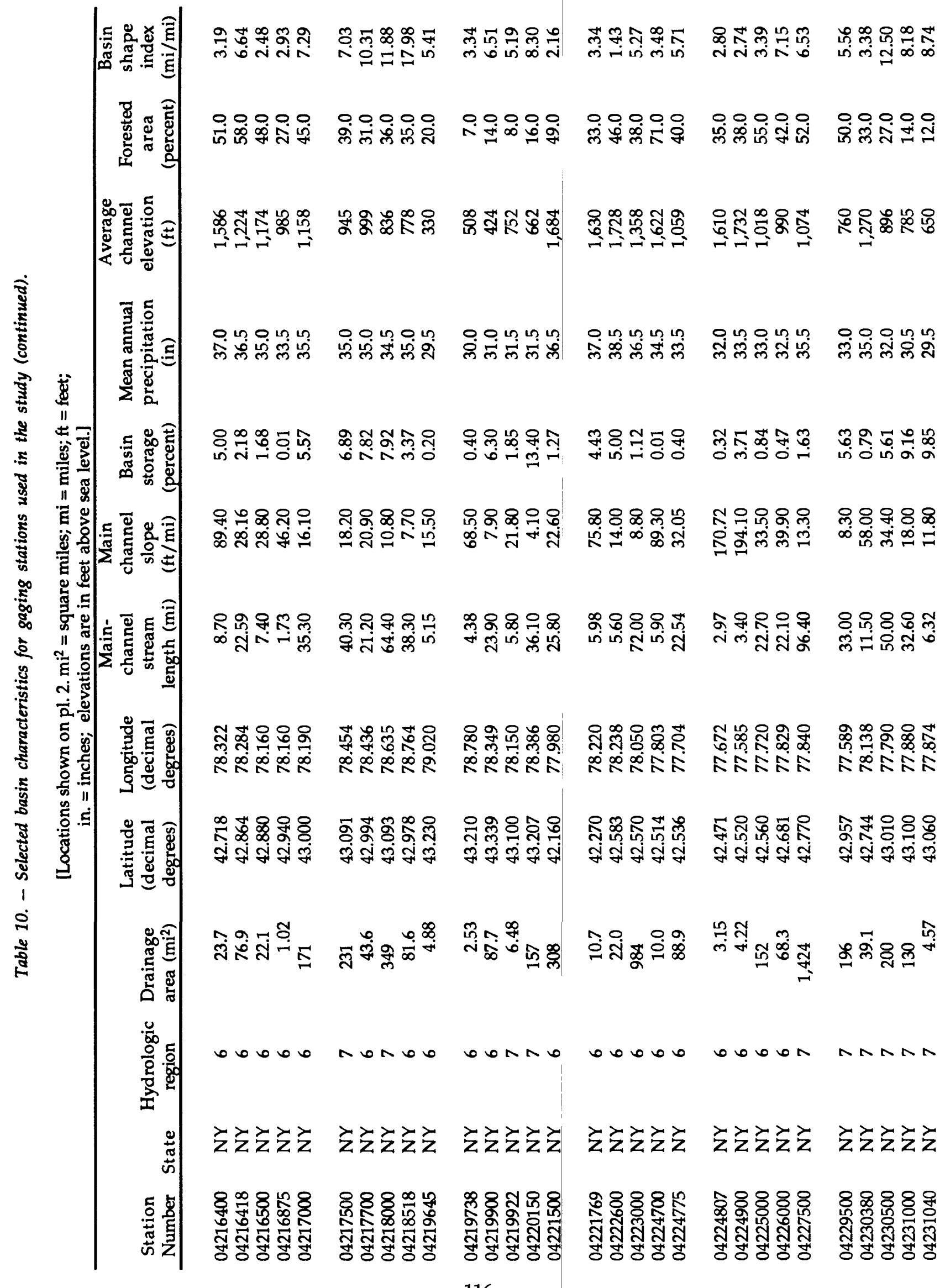




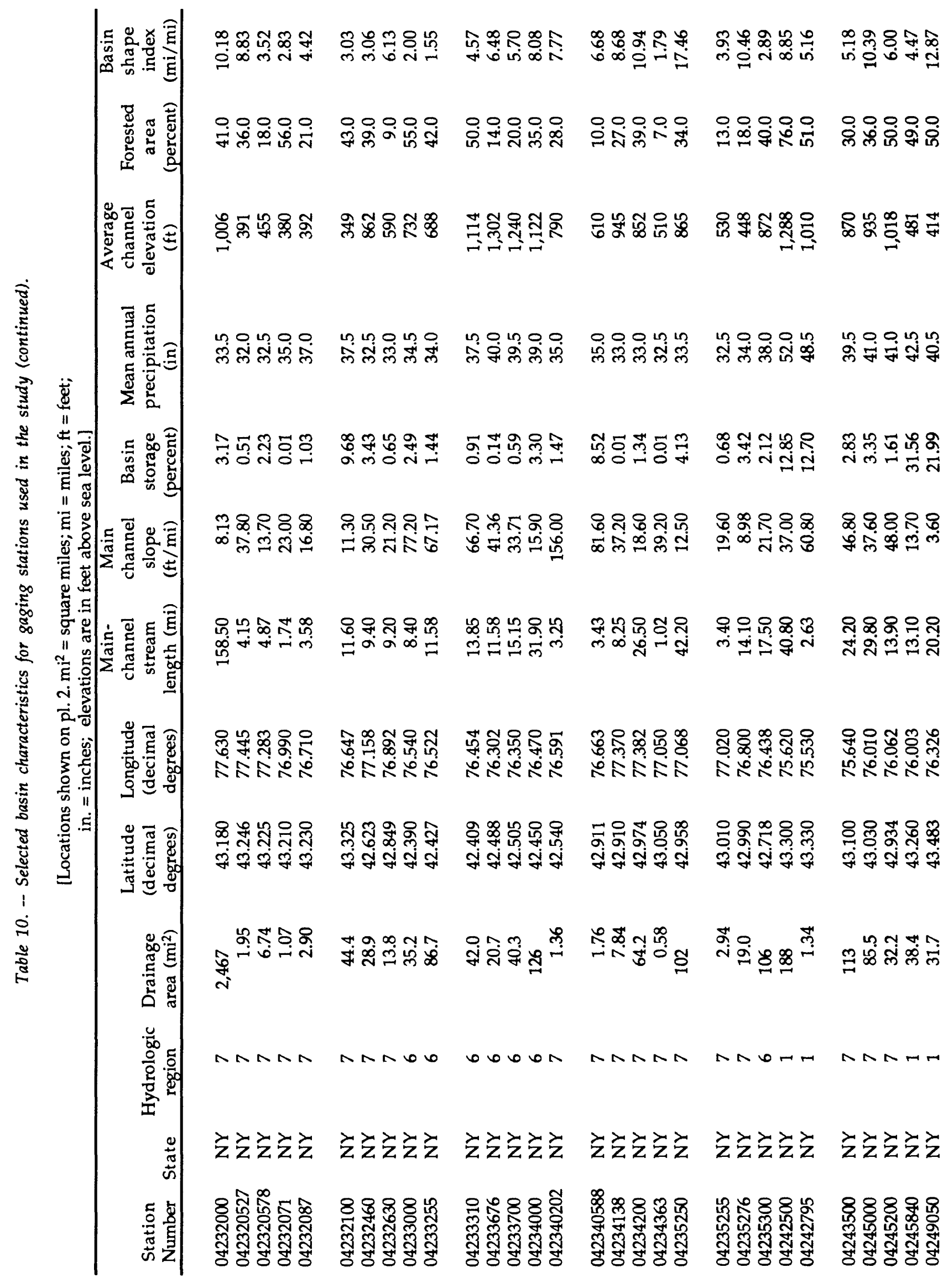




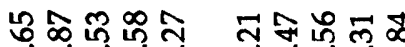

늉요

소용요

กำลำ

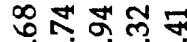
क क ज

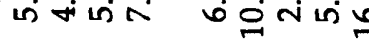

न人०

क तों

ONina

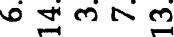

$0.000 \quad 00000$

0.0 .0 .0

0.0 .00

0.0 .00

웅웅우웅

め。

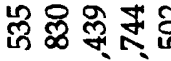

육육융웡

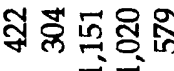

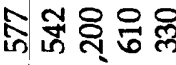

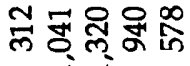

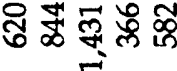

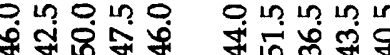

in 0.00

0.0 .000

우웅요요 웅

요웅 $\Sigma$

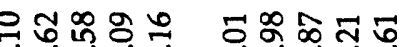

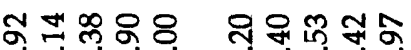

路下 88

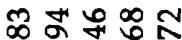

ㄱำ

이에

नें

퍼엣ำ

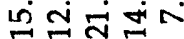

조요응ㅇㅇㅇ

8읏ㅈ중

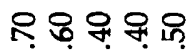

웅으유몽

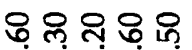

오오윰웅음

สี่

पूल लंख

궁

ت的㖞出

iि

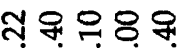

국우용ㅇㅇ

드윰유요요

요융ㅇㅇㅇ

으우요요응

음요유요

तेलें

웜

ஸ่

तेंक्ल

๓ं

용옹을욱유

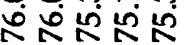

ิㅗํํㅇㅇㅠ.

ผ

ํํํํํํี่ำำ

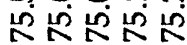

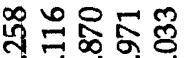

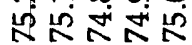

హెำㅇำ

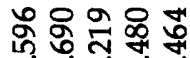

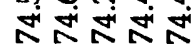

후웡

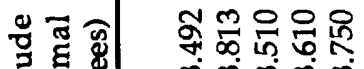

융융ㅇㅇㅇㅇㅇ

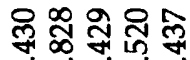

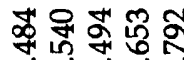

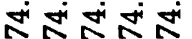

अभु अं

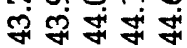

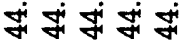

戈我我求

옹ㅇㅇㅇ용요

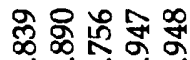

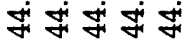

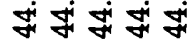

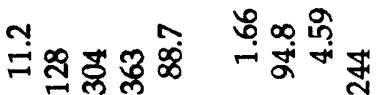

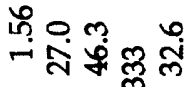

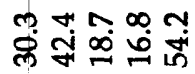

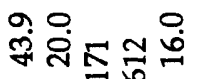

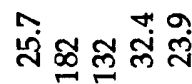

$\pi+n \pi t$

tann

nand

$\pi+n-\pi$

ルr+

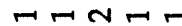

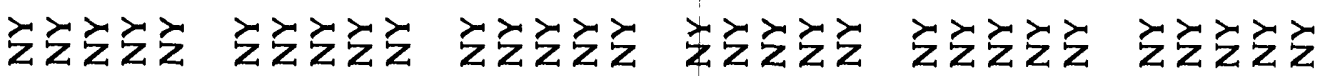

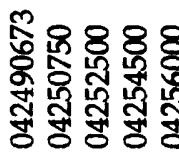

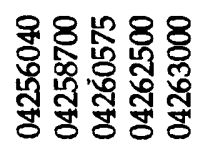

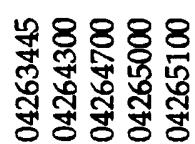

88888

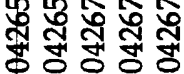

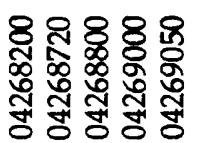

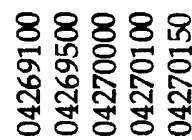




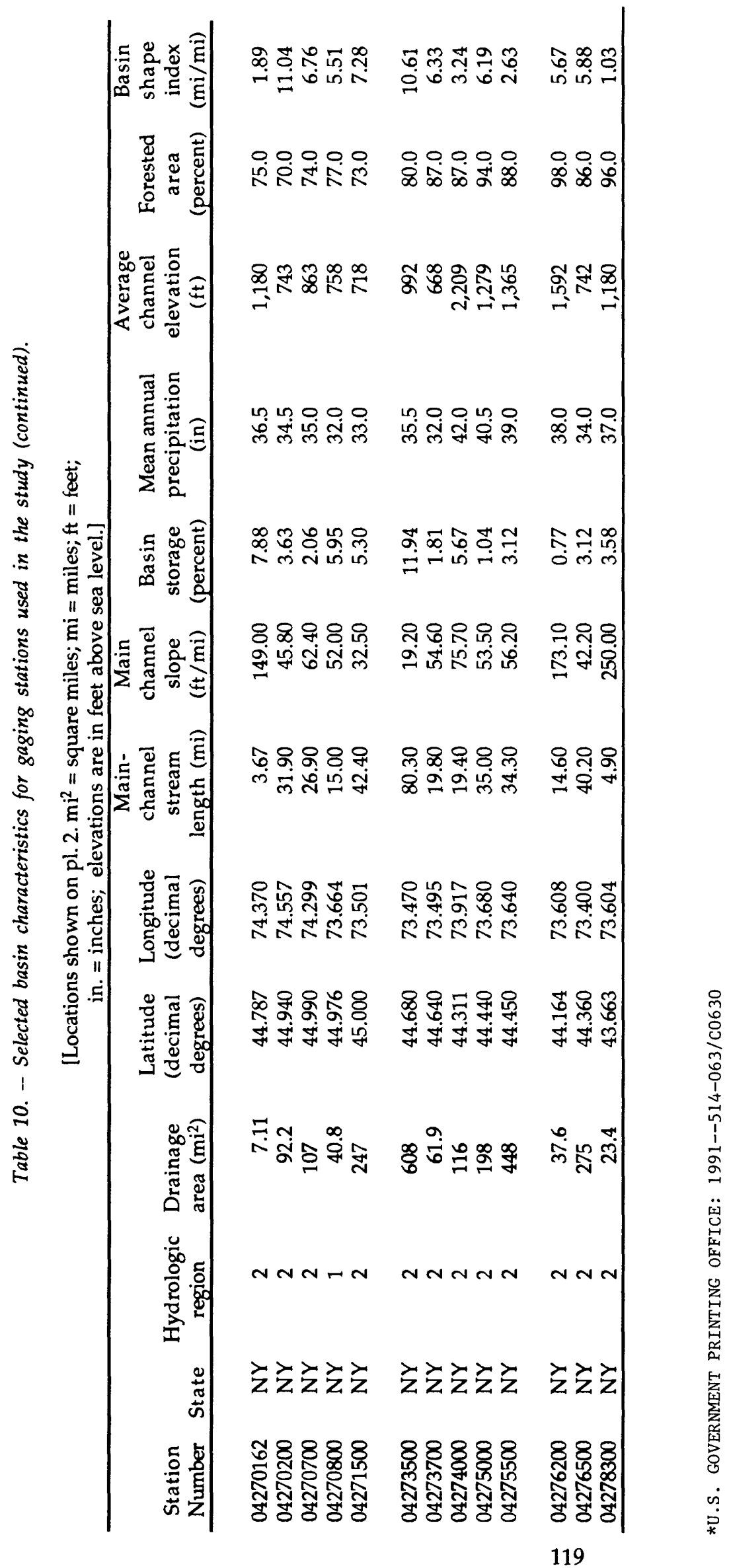

